\title{
Cross-retaliation in IP rights: addressing member asymmetries and compliance at the WTO
}

Citation for published version (APA):

Vargas Amaral, R. (2012). Cross-retaliation in IP rights: addressing member asymmetries and compliance at the WTO. [Doctoral Thesis, Maastricht University]. Wolf Publishing.

https://doi.org/10.26481/dis.20120330rv

Document status and date:

Published: 01/01/2012

DOI:

10.26481/dis.20120330rv

Document Version:

Publisher's PDF, also known as Version of record

\section{Please check the document version of this publication:}

- A submitted manuscript is the version of the article upon submission and before peer-review. There can be important differences between the submitted version and the official published version of record.

People interested in the research are advised to contact the author for the final version of the publication, or visit the DOI to the publisher's website.

- The final author version and the galley proof are versions of the publication after peer review.

- The final published version features the final layout of the paper including the volume, issue and page numbers.

Link to publication

\footnotetext{
General rights rights.

- You may freely distribute the URL identifying the publication in the public portal. please follow below link for the End User Agreement:

www.umlib.nl/taverne-license

Take down policy

If you believe that this document breaches copyright please contact us at:

repository@maastrichtuniversity.nl

providing details and we will investigate your claim.
}

Copyright and moral rights for the publications made accessible in the public portal are retained by the authors and/or other copyright owners and it is a condition of accessing publications that users recognise and abide by the legal requirements associated with these

- Users may download and print one copy of any publication from the public portal for the purpose of private study or research.

- You may not further distribute the material or use it for any profit-making activity or commercial gain

If the publication is distributed under the terms of Article $25 \mathrm{fa}$ of the Dutch Copyright Act, indicated by the "Taverne" license above, 


\section{CROSS-RETALIATION IN IP RIGHTS: \\ ADRESSING MEMBER ASYMMETRIES}

\section{AND}

\section{COMPLIANCE AT THE WTO}




\section{Cross-retaliation in ip rights: adressing member asymmetries}

\section{and compliance at the WTO}

R. Vargas-Amaral

ISBN: 978-90-5850-817-1

2012

\section{ฟolf Legal Publishers (WLP)}

POB 31051

6503 CB Nijmegen

The Netherlands

E-Mail: info@wolfpublishers.nl

www.wolfpublishers.com

All rights reserved.

No parts of this publication may be reproduced in any material form (including photocopying or storing in any medium by electronic means and whether or not transiently or incidentally to some other use of this publication) without the written permission of the copyright owner(s). Applications for the copyright owner's permission to reproduce any part of this publication should be addressed to the publisher. Disclaimer: Whilst the author(s) and publisher have tried to ensure the accuracy of this publication, the publisher and author(s) cannot accept responsibility for any errors, omissions, misstatements, or mistakes and accept no responsibility for the use of the information presented in this work. 


\title{
CROSS-RETALIATION IN IP RIGHTS:
}

\section{ADRESSING MEMBER ASYMMETRIES AND COMPLIANCE AT THE WTO}

\author{
DISSERTATION \\ to obtain the degree of Doctor \\ at Maastricht University \\ on the authority of the Rector Magnificus, \\ Prof. dr. G.P.M.F. Mols \\ in accordance with the decision of the Board of Deans, \\ to be defended in public \\ on Friday 30 March 2012, at 10:00 hours
}

by

Renata Vargas Amaral 


\section{Supervisor}

Prof. dr. mr. Anselm Kamperman Sanders

\section{Assessment Committee}

Prof. dr. mr. Gerard-René de Groot

Prof. dr. Peter Van den Bossche

Dr. Christopher Heath 
To my parents, Edson and Fátima, with all my love and gratitude 



\section{ACKNOWLEDGEMENTS}

And finally, here is my dissertation. I believe that only those who have gone through the process of writing a $\mathrm{PhD}$ dissertation know how it feels to get to the acknowledgements section. Most of the hard work was done by me, but I could never complete it without the material and emotional support of a number of very special people. I am afraid I cannot be fair with all of them in this text, but I am profoundly endebted to each one that made part of this process.

First of all I am very blessed for having a family like mine. Even with an ocean in between us, you were the best I could have during the period in Maastricht. Special thanks to my father, my mother and my sister who always believed in me and never let my down. Thank you for the love, patience and for giving me the strength to go on during the several hard moments.

I am very grateful for the opportunity given me by my supervisor, Prof. Anselm Kamperman Sanders. Thank you for inspiring me and making me believe that this could work. Thank you for opening the doors of the international world and integrating me in your privileged professional circle. Prof. Anselm supported me, trusted me and guided me during all the process. I am really grateful for everything.

Special thanks go to Dalindyebo Shabalala who was not only a great master, but also a lovely friend. Dyebo was present in every moment I needed and he was one important informal supervisor of this dissertation. Your competent comments and remarks made me more secure to go on. This dissertation would not be complete the way it was without you. Thank you, my friend. Your knowledge and your smile made me believe in this project.

I am also grateful to the professors, my friends and the staff of the Faculty of Law of Maastricht University. It was a great joy to share ideas and spend so many pleasant moments with you. Special thanks to Ria Wolleswinkel for her kindness and care and to Prof. Peter Van den Bossche for giving me the honor of sharing my research with him and hearing me with so much respect and attention. I think Prof. Peter does not realize what it meant to me to get to know him and be part of his circle. It meant a lot and it was one of the highlights of the period in Maastricht. I am deeply grateful for having Prof. Peter in my defense and reading my work. 
My sincere thanks to the professors, colleagues and friends from the Faculty of Law. Thank you for cheering me up, for the competent comments regarding my research and for so many nice talks and coffees together. Special thanks to: Nishara Mendis, Denise Prevost, Eliza Malathouni, Katharina Eisele, Phyllis Livaha, Arkady Kudryavtsev, Tamara Lewis and Viorelia Gasca.

During the period in Maastricht I have made many dear friends, who were my family and the best friends I could ask for. I was very blessed for having met Mart Mooren and Geeke Siemons, my Dutch parents, my friends, my family. Thank you for receiving me in your house with so much love and care. This dissertation is also yours and I will always love you. I am also grateful to my lovely friends Fernanda Costa e Silva, Mariana Rocha, Ionara da Costa and Heloísa Castello Branco for your friendship, your support and interest regarding this research. You were very important in Maastricht (and Brussels), especially in the hardest moments, you were all there. I will not forget that and I am deeply grateful to all of you.

I would like to mention professors Luiz Otávio Pimentel and Fernando Seabra, from the Federal University of Santa Catarina. Both believed in me and were responsible for sending me to Maastricht. I guess none of us knew how big and blessed this experience would turn out to be back in 2010. I had one of the best years of my academic life ever. And also thanks to Capes for providing me with financial support for the period I spent in Maastricht.

Special thanks also to Welber Barral, my friend and my dedicated supervisor in Brazil for so long. Prof. Barral is the example of professional I chose many years ago, when I first met him (I doubt he remembers that moment, but I will never forget it). Thank you for your care with me reflected in your dedicated remarks in my work, but also as a friend worried about my personal and professional life. It is an honor to have you as a friend and I am very grateful for that.

Also in Brazil I could count with somebody who at this point might know more than me about my research, Kyria Finardi. Kyria was not only the careful supervisor of my English during the writing of this dissertation, but she was also and more than anything, a faithful friend I could call at any time (thanks to skype!). Kyria was one of the first people to give me all her support to move to Maastricht. She made me believe I could do it. And we did it, together. 
Well, I do not know if anybody can do a $\mathrm{PhD}$ without friends, but I know I col not. I want to express my deep gratitude to my friends from far away who never let me alone while I was in the Netherlands. From Brazil I have many people to thank, but I want to specially thank Luiza Zuanazzi França, Silvia Varella, Fernanda Wolff, Luciana Camila de Souza. You were always present during this period, cheering me up and sending all your trust in me. I admire you all very much and I am grateful for sharing my life with you. From Macau, I want to mention my lovely friend Zhao Fei, who I met during a study trip to Macau and who has been a blessing in my life since then. Your kindness and love make me a better person. Thank you for your support my dear.

Many people have contributed to the completion of this work, but the lines are not enough to be fair to everyone. I am very grateful to all of you who directly or indirectly made part of this project. Here it is!

A journey of a thousand miles starts with a single step.

Laozi, Tao Te Ching, Ch. 64, line 12. 


\section{LIST OF ABBREVIATIONS}

AB - Appellate Body

ACP - Asian, Caribbean and Pacific former colonies

CAMEX - Câmara de Comércio Exterior

DS - Dispute Settlement

DSB - Dispute Settlement Body

DSU - Dispute Settlement Understanding

EC - European Community

EPO - European Patent Office

EU - European Union

GATT - General Agreement on Tariffs and Trade

GATS - General Agreement on Trade in Services

GI - Geographical Indication

ICITO - Interim Commission for the International Trade Organization

ICJ - International Court of Justice

ICTSD - International Centre for Trade and Sustainable Development

ILC - International Law Commission

IMF - International Monetary Fund

INPI - National Institute for Industrial Property

IP - Intellectual Property

IPRs - Intellectual Property Rights

ITO - International Trade Organization

LDC - Least Developed Country

MFN - Most Favored Nation

NAFTA - North American Free Trade Agreement 
OECD - Organization for Economic Co-operation and Development

PIL - Public International Law

PPA - Protocol of Provisional Application of the General Agreement on tariffs and Trade

PCT - Patent Cooperation Treaty

R\&D - Research and Development

SCM - Subsidies and Countervailing Measures

TRIMS - Agreement on investment measures related to trade

TRIPS - Trade-Related Aspects of Intellectual Property Rights

UN - United Nations

UNCTAD - United Nations Conference for Trade and Development

US - United States

WIPO - World Intellectual Property Organization

WTO - World Trade Organization 


\section{LIST OF TABLES AND FIGURES}

Table I - World Bank GDP Indicators Database July 2011

p. 84

Table II - WTO data on dispute settlement participation by country

p. 85

Table III - Likelihood of State Compliance

p. 98

Table IV - Prisoner's Dilemma

p. 99

Table V - IP Regimes

p. 148

Table VI - Volume Changes in Private Consumption

p. 192

Figure 1 - Reward Theory

p. 124 


\section{TABLE OF CONTENTS}

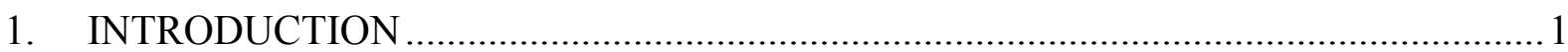

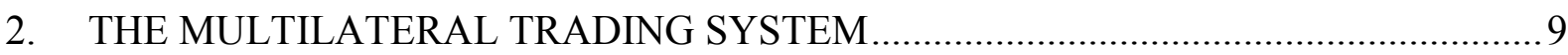

2.1 International Law and International Economic Relations: overview ....................... 9

2.2 International Economic Relations: Economic Globalization................................. 17

2.3 The emergence of the Multilateral Trading System: history and evolution since

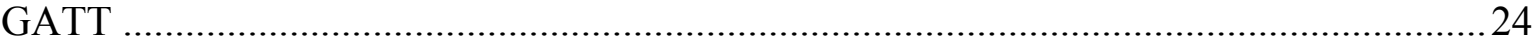

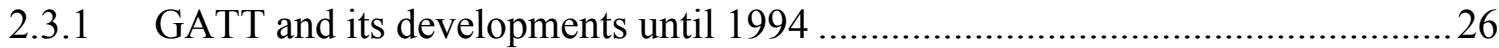

2.3.2 Changes in 1994: the WTO institutional framework ........................................ 34

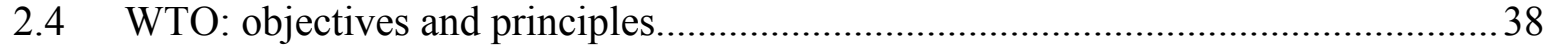

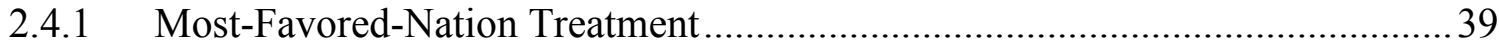

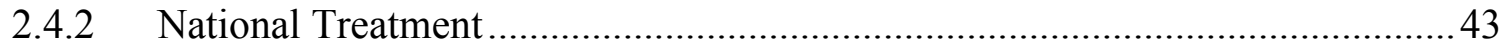

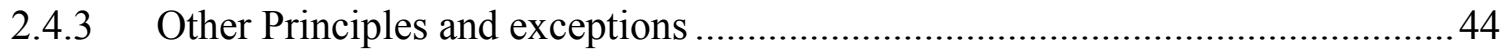

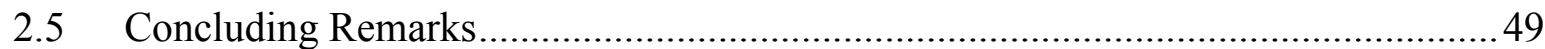

3. WTO DISPUTE SETTLEMENT AND COMPLIANCE: strengths, weaknesses and

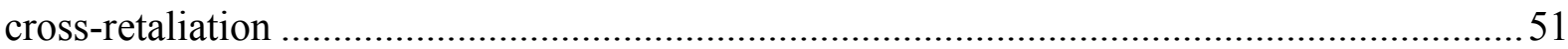

3.1 Jurisdiction of WTO Dispute Settlement Body .......................................................52

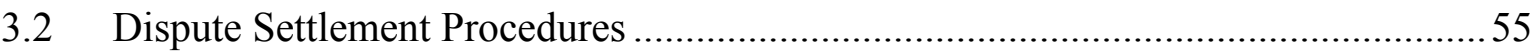

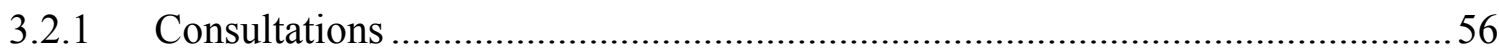

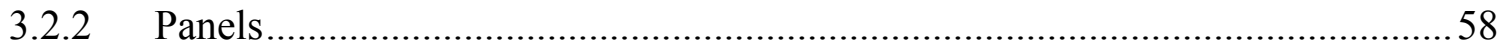

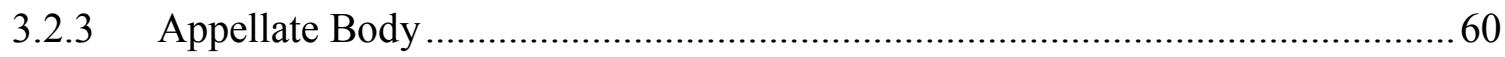

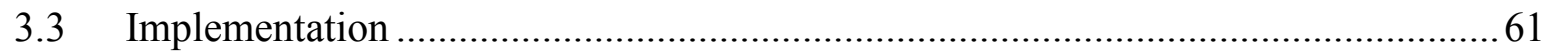

3.3.1 WTO Remedies: Compensation Measures and Suspension of Concessions ..... 65

3.3.2 Potential difficulties that should be considered ............................................ 75

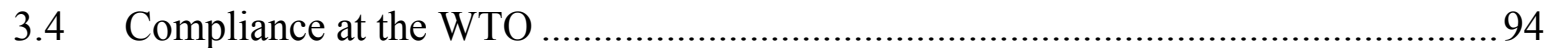




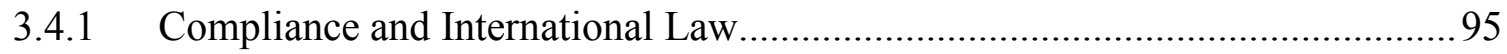

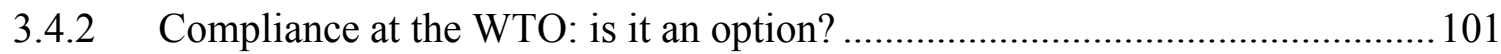

3.5 Cross-Retaliation: an attractive option for developing countries ........................... 108

3.5.1 Cross-Retaliation as a development vehicle to WTO members ........................ 113

3.5.2 Feasibility of proposals to reform the DSU on behalf of developing countries114 3.6 Concluding Remarks

4. ESPECIAL ATTENTION TO INTELLECTUAL PROPERTY RIGHTS: crossretaliation in TRIPS

4.1 General Issues of the TRIPS Agreement and IP framework ............................... 122

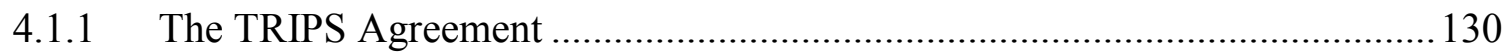

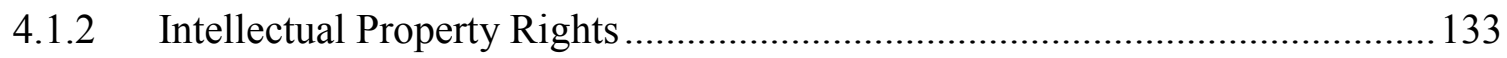

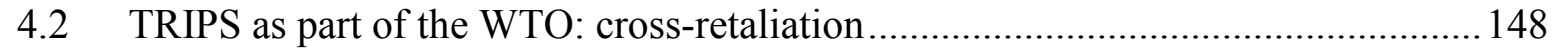

4.2.1 Basic rationale to calculate the level of retaliation....................................... 150

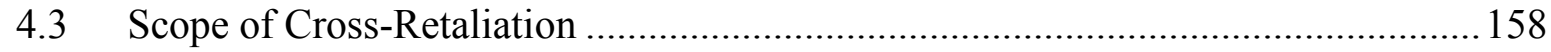

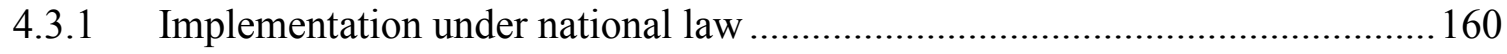

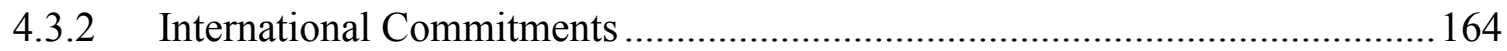

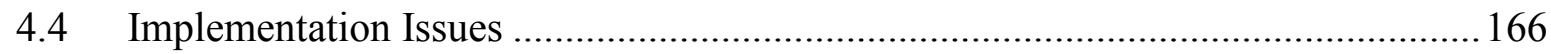

4.4.1 Economic Feasibility: basic knowledge, domestic market size, costs of implementation 166

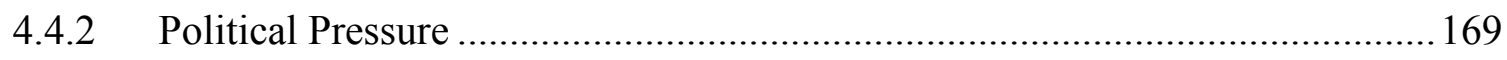

4.5 Does Cross-Retaliation in TRIPS addresses the basic issue of non-compliance? ... 170

4.6 Selected Cases: approved requests for IP cross-retaliation ................................ 174

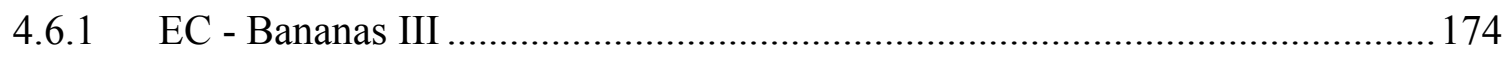

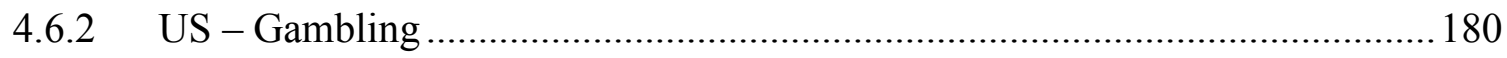

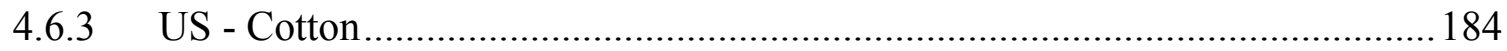

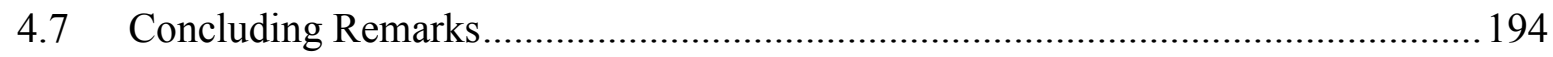




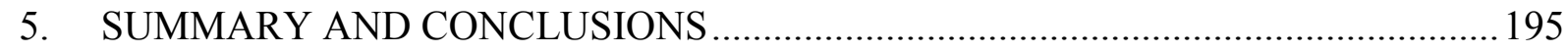

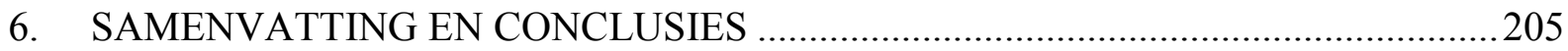

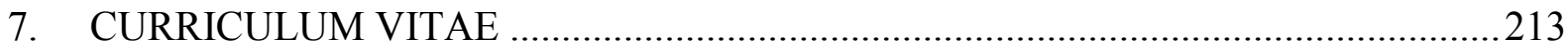

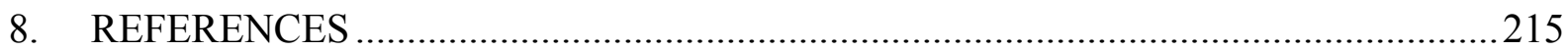





\section{INTRODUCTION}

It has been argued by some that WTO member finding itself in a losing position in the WTO dispute settlement system has a free choice on whether or not to actually implement the obligations spelled out in the adopted Appellate Body or panel reports: the alternatives being simply to provide compensation or endure retaliation. This is an erroneous belief. [...] To allow the countries to "buy out" of their obligations by providing "compensation" or enduring "suspension of obligation" also creates major asymmetries of treatment in the system. It favors the rich and powerful countries which can afford such "buy outs" while retaining measures that harm and distort trade in a manner inconsistent with the rules of the system. It turn that can only diminish the extent to which companies, trading and investing, can rely on the rules to provide market predictability.

Consultative Board to the WTO Director-General, 2004.

The dispute settlement mechanism of the multilateral trade system has motivated an impressive volume of studies and reports worldwide since the creation of the World Trade Organization (henceforth WTO). Trade flows have increased and multilateral commercial exchanges are currently - and more than ever -, extremely important elements of international relations among States.

Trade is not only an exchange of products and services between countries, but also a relevant tool for the development of economies and societies. Among many benefits, trade liberalization promotes the improvement of better negotiation environments which were, as a result more: (i) conducive to foreign investment; (ii) open for the formation and improvement of scale economies - with the consequent overall drop in prices of products; (iii) conducive to the technological innovation and the exchange of knowledge through joint research and development around the world; (iv) improving to the level of economic development of multilateral players by providing wider access to goods, services, employment and knowledge.

As trade relations increased and became more sophisticated, the disputes related to trade topics ruled by WTO agreements also became more frequent. Indeed, the number of 
reports under WTO law has increased substantially compared to the dispute settlement under GATT. In its young existence, the WTO dispute settlement system has dealt with no less than 427 disputes to date.

The large number of trade disputes indicates not only disagreements between members on the consistency of trade measures, but also that the establishment of a ruleoriented mechanism brought a safer and more comfortable environment for the settlement of disputes. The dispute settlement system addresses stability to the multilateral trade and indicates the credibility of members to solve their controversies under a predictable settlement system.

Unquestionably, the WTO dispute settlement system is one of the most important innovations of the Uruguay Round. Nevertheless, though the system appears to be very effective, there are failures and defects that must be taken into consideration and accounted for. Moreover, it is remarkable that every instance of noncompliance in the WTO is very problematic in terms of economic and social losses.

The present research endeavour is motivated by the quest to better understand the instances of noncompliance and the remedies available to address the failures in implementing the Dispute Settlement Body (henceforth DSB) recommendations and rulings. Despite the fact that there are significant problems in the disputes where the complainant and the respondent are powerful economies, the study focuses on complications that arise when the complainant in a WTO dispute is a developing country member while the respondent is a developed country member.

More specifically, this study is interested in the implementation phase of DSB decisions. That is the phase when the economic asymmetries are highlighted, as the greater or lesser importance of a certain market access seems to be determinant to the decision to comply with a WTO dispute settlement decision. Indeed, if an affected developed country member confronted by a winning developing country member in the dispute settlement prefers to pay the price of noncompliance instead of complying with the decision, there seems to be no way for the complainant to induce compliance.

Taking into account the abovementioned scenario, this thesis tackles the remedies provided by the Dispute Settlement Understanding to deal with problems of implementation and compliance with decisions taken pursuant its provisions. Especially, the study focuses on the mechanism of cross-retaliation in intellectual property rights, as it has been repeatedly put 
forward by academics and professionals as a possible solution for the economic asymmetries of opponents in a trade dispute.

Thus, the hypothesis raised in the present dissertation assumes that even though the dispute settlement system has held high rates of compliance since the establishment of the WTO, there are challenges to the effectiveness of the system once it allows developed country members to buy out their obligations in different ways. Therefore, despite the fact that the cross-retaliation in Trade-Related Aspects of Intellectual Property Rights (henceforth TRIPS) appears to be a successful solution at first glance, the study will address challenges that may be present in the actual use of such mechanism and whether it is really a feasible option for WTO developing country members.

Accordingly, the research problem that motivates the study can be formulated as follows: taking into account the large economic imbalances of WTO members and the difficulty of developing country members to induce compliance with WTO decisions, does cross-retaliation in TRIPS contribute to a better effectiveness of the dispute settlement system in what concerns developing country members?

In that sense, the main objective of the present study is to analyze the real utility of the suspension of concessions or other obligations under TRIPS to the greater effectiveness of the dispute settlement system (especially referring to the developing country members) and whether it addresses the issue of noncompliance with DSB decisions.

Before proceeding, one clarification is due. Although the concept of developing country is going to be better explained in the body of the research paper, it is worth defining from the start, what the author considers to be a developing country. The WTO does not give any detailed definition of the concept, and only separates it in a different and explicit category from that of the Least-Developed Countries.

Nonetheless, for the sake of this study and with practical purposes, the author chose to divide the country members into two groups, that of developed and that of developing country members. The former are the most powerful economies identified by the World Bank with a high level of economic, social, health and education development; such as the United States, most European countries, Japan, Canada, among others. The latter are all the other 153 WTO members that are clearly not developed (including the very small economies). Inside this last group the author highlights an exception for Brazil, China, India and other developing country members with especial economic characteristics that make their 
economies more competitive and distinguishes them from regular developing country members ${ }^{1}$.

The proposed research question is a comprehensive reflection that goes beyond the realm of purely legal or economic issues; instead, it seeks elements for understanding the complexity of decisions in international trade. The author intends to promote an interplay of theories of Public International Law, International Relations and International Economic Law. Gathering the information made available by the authors of those disciplines, the research aims to map important elements and promote a grounded discussion on WTO dispute settlement issues. Certainly, the retaliation in the WTO is one of the most multi-disciplinary issues of the system, and therefore one of the richest subjects in terms of details and finegrained nuances.

Notably, the lessons from International Public Law are fundamental to the development of the present research project. Above all, the notions of State responsibility are indispensable here. The WTO (and its members) as an international organization established by a treaty of International Public Law shall observe the legal provisions of the general international law framework. Therefore, States that breach international law obligations - in this case, WTO law -, shall be held responsible.

International Economic Law is the central area of studies that guides the discussion in this dissertation. Trade and economic relations are all designed and directly influenced by provisions of International Economic Law. All WTO subjects are defined by it. To address elements of the economic globalization and the multilateral trade relations, the present study used mainly writings of John H. Jackson and Peter Van den Bossche. Among other important sources used, those authors presented a robust understanding of the International Economic Law following the same stream of thought which is considered adequate to the discussion proposed.

Adding to those authors, especially in what refers to the issues of WTO dispute settlement, other scholars, among whom are Gregory Shaffer, Marc L. Busch and Eric Reinhardt, Petros Mavroidis, Steve Charnovitz and William Davey were used as important sources and contribution to the argumentation of the present research endeavor. More

\footnotetext{
${ }^{1}$ For the sake of information, according to the World Bank data, Brazil is classified as an upper middle income economy; China is classified as a lower middle income economy and; India is classified as lower income country. For more information see: <http://data.worldbank.org/country>.
} 
specifically and in what refers to cross-retaliation in TRIPS, the contributions of Frederick Abbott, Henning Grosse Ruse-Khan and Joost Pauwelyn were indispensable to the development of the research and confronted with different positions of other distinguished authors.

By analyzing elements and facts in a different and comprehensive manner, the present dissertation brings a contribution to the state of art of international law. With a comprehensive research on available sources on the subject, the study seeks to contribute with a competent and detailed reflection of the cross-retaliation in TRIPS and the real utility of this mechanism to the developing countries. Also, since the backbone of the present research endeavor is the imbalance of the multilateral trade relations, the author intends to address ways of correcting the current system by focusing on the dispute settlement.

The relevance of the subject is clear. Most of the trade exchanges around the world are subject to WTO law. Most of the members that adhered to the multilateral system experienced an increase in their social welfare. Nonetheless, the asymmetries that separate the countries are significant and seem to become even more so when smaller economies do not have the strength i.e. financial resources and building capacity to follow the increase of trade shares.

In that context, the implementation phase of WTO dispute settlement decisions is the moment when the asymmetries are highlighted. Normally, millions of dollars are involved in one single dispute. That may not be very meaningful to powerful economies, but may crash entire sectors of economy of developing countries. Intellectual property rights came to the arena because intellectual assets are mostly located and developed in wealthy countries. Even though suspension of concessions or other obligations are normally understood as a great "discovery" and a strong threat in order to cross-retaliate, this dissertation aims to go in detail and identify whether the mechanism is useful (and if so to what extent) for all WTO developing country members and in which conditions.

The dissertation is divided into three chapters and a conclusion. The methodology used to develop the research is inductive while the method of procedure is monographic and comparative. The research was carried out mainly with the use of bibliographical references, official data and primary documents.

Chapter two aims to present a comprehensive approach of the emergency of the global economy and its institutions. Special emphasis will be given to the creation of the 
multilateral trading system and the institutional framework of the World Trade Organization. Since all the subjects treated in this chapter are elements of International Economic Law, which is a branch of International Public Law, it is necessary to address elements of the latter that affect the present research. For that reason the beginning of the chapter will refer to issues of State responsibility and State sovereignty. Further on, the chapter will describe history and evolution of the multilateral trading system and the main objectives and principles of the World Trade Organization.

Chapter three focuses on the dispute settlement system specifically by tackling the elements that form and define the dispute settlement framework for multilateral trade disputes. It will also analyze the jurisdiction and procedures of the system, with especial attention to the implementation phase of the Dispute Settlement Understanding. Also and very important, the chapter will address the binding effect of DSB recommendations and rulings and the primary effects identified because of the economic asymmetry of WTO members. The chapter ends by addressing the possibility of cross-retaliation for developing country members.

Still, chapter three refers to the compliance with the DSB recommendations and rulings. After the debate carried out in the previous chapters, it is relevant to understand what compliance at the WTO means and whether the high rates indicate that there is no need to worry about the system. As compliance is an element of general international law, the chapter initiates addressing the literature on compliance in public law before proceeding to identify compliance at the WTO. After a thorough discussion on suspension of concessions in TRIPS, this chapter aims to understand whether and until what extent cross-retaliation in intellectual property rights addresses the basic issue of noncompliance. The study tries to seek ways towards a more balanced trade once what stimulates the whole dissertation is, after all, the imbalance in multilateral trade relations. To finalize the chapter, the author refers to issues of reform of the system suggested by WTO members discussing their feasibility.

Next, using the knowledge provided by the previous chapters, chapter four is especially dedicated to the issue of intellectual property rights. In this chapter the possibilities of cross-retaliate in TRIPS will be tested as well as whether or not there are feasible options for developing country members. The chapter presents an overview of intellectual property theory, with emphasis on the different intellectual property rights and to the TRIPS Agreement. The overview provides the background to discuss the suspension of intellectual 
property obligations related to cross-retaliation in the WTO. The chapter also reflects on the basic rationale to valuate TRIPS obligation and to calculate the level of retaliation. Very important to the conclusions of the dissertation, the chapter furthermore addresses the challenges and the costs - economic, political, legal - of cross-retaliating in TRIPS. Finally, the chapter reviews the three WTO cases in which requests to cross-retaliate in TRIPS were approved.

Chapter five presents the conclusions to the central research question: taking into account the large economic imbalances of WTO members and the difficulty of developing country members to induce compliance with WTO decisions, does cross-retaliation in TRIPS contribute to a better effectiveness of the dispute settlement system in what concerns developing country members? At the end a summary of the research and its findings is presented. 


\section{THE MULTILATERAL TRADING SYSTEM}

The purpose of this chapter is to present a concise overview of the multilateral trading system and discuss the emergence of a global economy after the advent of the Second World War. Also and more important, this chapter intends to explore the institutional framework of the World Trade Organization and its most important principles so as to ground the discussion that will follow.

This chapter starts with a brief reflection on the current situation of international relations particularly in what concerns aspects of international law and the emergency of a global economy. So as to understand the complexity of decisions in international trade within the theory of Public International Law, International Relations and International Economics, the chapter presents essential elements of International Law and addresses issues of economic globalization and economic development which are considered important to understand the purpose of this dissertation.

Section 2.3 deals with the history and development of the WTO since the GATT 1947 explaining how the WTO became one of the most important international organizations in the world nowadays.

To complement section 2.3, section 2.4 encompasses the objectives and principles of the WTO, the goals pursued by the Organization and its members. This section will also tackle the efforts done by the WTO to promote and liberalize the international trade.

In possession of the information brought by the theoretical framework chosen for this first chapter, this dissertation will be conducted with the intention of exploring the interplay between asymmetries among WTO members and whether they influence or are related to the (non) compliance with WTO rulings, as well as the role of cross-retaliation in TRIPS as a second best option for developing country members.

\subsection{International Law and International Economic Relations: overview}

The discipline of International Law encompasses a number of terms and definitions that can be discussed in this dissertation. The main focus of this work is not to delve into the concept of these terms, however, it is worth highlighting that some important 
concepts - such as State responsibility and sovereignty of States should remain clearly defined throughout this work, since they may directly or indirectly influence the reflections proposed hereafter.

All the principles of international law are briefly taken into account in this work, in order to explain how the WTO was born through a treaty of international public law among States. However, some concepts central to the research question, such as the responsibility of States as actors of international law and their obligation to implement the decisions adopted by the Organization, will be discussed in greater detail. Also, it is important to bear in mind what this dissertation understands by sovereignty of States in a world with social, political and economic globalized traits.

\section{- International Responsibility of States}

Following the thought of Pierre-Marie Dupuy that international responsibility of the state "is the epicenter of a legal system" ${ }^{2}$ the international responsibility of States is one of the pillars of international law relations among these subjects. There has been great difficulty for the actors of international relations to assimilate their obligations and, therefore, the responsibility they have in the international community with other states under international law since the formation of the modern state and the recognition of sovereign equality of States in the Peace of Westphalia in 1648.

The French Revolution may be regarded as a milestone for the end of the absolute irresponsibility of States. With the consolidation of the modern State and the promulgation of the French Constitution in 1789, international law effectively imposed a series of obligations on states, which then became equally sovereign and therefore equally responsible; thus having to comply with international norms. From that combination of factors arises - as Oppenheim says - , the fact that the international responsibility of a State to respect its international legal obligations is different from its internal autocracy. The responsibility for such obligations, according to the author, is a "quality of every State as an International Person, without which

\footnotetext{
${ }^{2}$ Dupuy, 1984, p.21
} 
the Family of Nations could not exist peacefully. State responsibility concerning international duties is therefore a legal responsibility"3.

Indeed, the growing interdependence of countries on the one hand, and the need for a more flexible notion of the Westphalia sovereignty on the other, reaffirms the daily increase of social, economic and political interaction among States ${ }^{4}$.

To date, States remain the main actors of the international law and international relations, and much of international norms, customary or conventional, derive from the will of the State. In the absence of a supreme entity to which all States must submit, the respect for the principle of international responsibility has particular importance as it establishes and guarantees (or tries to ensure) the sovereign equality of States, especially when there are breaches of an obligation under international law 5 .

Departing from the argument that the international responsibility of States, especially after the Peace of Westphalia, represents, together with the principle of national sovereignty, the axis of any relationship among states within the international community, it was in this period - between the $16^{\text {th }}$ and $17^{\text {th }}$ centuries - that the authors concerned with international law began to think and design theories for the accountability of States.

Alberico Gentili redefined the concept of international responsibility of states and added possible solutions to the problem of accountability of states, in relation to each other ${ }^{6}$. Strongly based on principles derived from Roman law, therefore, private law, Gentili founded his whole idea of responsibility from the theory of guilt and deceit, as well as humanistic reasons systematized by him about a just war?

\footnotetext{
${ }^{3}$ Oppenheim, 1937, p. 273.

${ }^{4}$ Despite the benefits of this tangle of connections that exist today worldwide, it is important to note that these relationships significantly increase the international responsibility of countries.

${ }^{5}$ According to Pereira, the international responsibility of the state is the "response to a disruption in the legal balance (triggering event), which seeks out direction to remedy the situation caused". See Pereira, 2000, p. 22.

6 The strong connection that Gentili (1552-1608) makes between the private and the need for rules and limitations for the international community is explained by the fact that the author found himself embroiled in a historical moment of rupture between the theological concept of the international community from the Renaissance, and the first steps of Modernity.

7. See Gentili, 2004, p. 39. Note that Gentili lived in a remarkable moment in history, on the border of modernity. This explains why the author did not use the term international law, but law of nations or the law of war and explains why Gentili brings strong connections in his work with private law (Roman) with the latent need for an international law that regulated and limited the relationship among states.
} 
Following the developments in international law, the theory of international responsibility of states found in the work of Hugo Grotius an even stronger identity ${ }^{8}$. Based on the writings of this Dutch author from the school of natural law the theory of international responsibility of the state develops and is spread by Zouch, Pufendorf, Wolff, Cocceio, Burlamarqui, and Vattel ${ }^{9}$.

By the beginning of the twentieth century Anzilotti started to outline the concept of international responsibility of States as the majority of authors accept it nowadays. In developing his theory of international responsibility of States, Anzilotti reaches an objective concept of international unlawful act, which, according to the author consists in "any violation of a duty imposed on an international legal norm, i.e., contrary to a promise of one State to the others." 10

As aforementioned, State responsibility was outlined by historical practices and customs, and the main coding attempts appeared in the early twentieth century. In April 1930, at the Conference for the Codification of International Law, the League of Nations attempted to formulate a project on international liability for damage to persons or overseas goods, but there were no practical results on this topic ${ }^{11}$.

Over the years, the relations among states are refined and strengthened. It is therefore in a context of gradual internationalization of relations between subjects of international law that arise, especially after the Second World War, robust multilateral organizations to handle the most varied topics of interest of nations.

After the Second World War, the legacy of the League of Nations on rules regarding the international responsibility of States was transferred to the United Nations together with the task of promoting the codification of international law ${ }^{12}$.

The International Law Commission (ILC), so as to delve into the coding of the issues involving the international responsibility of States appointed, in 1963, the Italian

\footnotetext{
${ }^{8}$ See Grotius, 2005, p. 17. Translation of Ciro Mioranza.

9 Ago, 1978, p. 274.

${ }^{10}$ Anzilotti, 1964, p. 386. In the same stream of thought as Anzilotti, in 1913 Marinoni affirms that the State is an unit for the international law and it is the holder of international law. The state, within the framework of international law presents itself as a unit subject to rights and duties, says Marinoni. Internally it results from a real diversity of staff, which together form the State organization. See Marinoni, 1913

11 This project was constituted by ten articles that can be found in the Yearbook of the International Law Commission of 1956.

${ }^{12}$ Yearbook of the International Law Commission 1969, § 41.
} 
rapporteur Roberto Ago. Ago presented eight reports on the subject between 1969 and 1980 . Departing from Ago's reports and studies, the ILC took note of thirty-five articles, which now form the basis of the current coding project, approved in 2001 by the UN General Assembly ${ }^{13}$.

The ILC Articles on State Responsibility are divided into four parts. The first part deals with the internationally wrongful act: general principles (Chapter I); attribution of wrongful conduct to the State (Chapter II); break of an international obligation (Chapter III); State liability in connection with the act of another State (Chapter IV) and; the circumstances that lead to preclusion of wrongfulness (Chapter V). The second part deals with the content of state responsibility: general principles (Chapter I); compensation for damages (Chapter II); the serious violations of obligations of peremptory norms of general international law (Chapter III). The third part, in turn, deals with the implementation of international responsibility of the state: the invocation of the responsibility of the State (Chapter I) and countermeasures (Chapter II). Finally, the fourth part addresses general provisions.

The ILC articles seek to formulate, according to James Crawford - rapporteur of the current project - by way of codification and progressive development of the theme, the basic norms of international law concerning the responsibility of States for their internationally wrongful acts.

The reason for this brief overview about the international responsibility of States relies on the fact that the WTO is an international organization born under a treaty of International Public Law meaning that every relation between members of the WTO is under that umbrella ${ }^{14}$.

\section{- Sovereignty of States}

\footnotetext{
${ }^{13}$ See Yearbook of International Law Commission 1970, $§ 22$. It is worth mentioning that further developments of international law - with emphasis to the creation of the United Nations after World War II -, strengthened the notion of State responsibility. If a State commits an internationally wrongful act, such breach gives rise to a liability not only to the injured state, but also to the organization and the international community itself.

${ }^{14}$ Moreover, it is interesting to mention that the actual draft of Convention on International Responsibility of States make it clear that "general international law that the state can be held responsible for illegal actions and omissions, and legal consequences that follow." Crawford, 2002, p. 74.
} 
Sovereignty is one of the fundamental concepts of international law. It is part of the principles that affirm the equality and political independence of States referred to in Article 2 of the UN Charter ${ }^{15}$.

The elements that compose the classical concept of sovereignty clearly appear in the international scenario of the seventeenth century with the end of the Thirty Years War ${ }^{16}$. The Westphalia treaties of 1648 that ended the Thirty Years' war in the Holy Roman Empire and the Eighty Years' war between Spain and the Dutch Republic, were a milestone for the European society of that century. To the extent that with the treaties the peace was restored in Europe, they established the beginning of a new phase in the political history of that continent, while eliminated the supreme power of the Catholic Church, giving the States the right and power to freely negotiate on their own, thus being responsible in international policy ${ }^{17}$.

The term sovereignty was then in close connection with the definition of the modern state. The State is manifested through the sovereignty, which in turn justifies the actions of the absolutist States as it attributes to the States the absolute power.

Indeed, after the Middle Ages it was considered that the power of the State was independent and offered to prince unconditionally all the. The sovereignty doctrine was transformed into absolutism. Moreover, in accordance with Jellinek, while Bodin was inserted in the turbulences of the civil wars he may have considered that the only way for salvation of the state was the recognition of the omnipotence of the $\mathrm{King}^{18}$.

\footnotetext{
${ }^{15}$ United Nations Charter, 1945.

16 The Thirty Years' War (1618-1648) consisted of a series of religious and political bloody conflicts, especially in Germany, where German constitutional issues, especially the rivalry between Catholics and Protestants gradually spread to the rest of the European continent. Despite the cause of religion, the conflict involved the efforts of France and Sweden to eliminate the Habsburg dynasty in Austria.

${ }^{17}$ According to Daillier, Dinh and Pellet, the Treaties of Westphalia were described as Europe's Constitutional Charter, which formally legalized the birth of new sovereign states and the new European policy letter that resulted therefrom. See Daillier; Dinh; and Pellet, 2003. Note that by the XV century it was understood that sovereignty was an unlimited and perpetual power, which was subjected only to divine and natural laws. There was a belief in the need to fully concentrate power in the hands of the ruler towards his subjects. The sovereign power would be fully transferred to the divine representative. The concept of sovereignty was first systematized by the French jurist Jean Bodin. The author, a staunch defender of the monarchy, has examined the principle of sovereignty in his Les six livres de la Republique, in which he conceptualizes sovereignty as unlimited and perpetual power, finding its limits only in the divine and natural laws. Bodin, 1977

${ }^{18}$ Jellinek, 2000, p. 415.
} 
Yet, Thomas Hobbes appears in the XVII century publishing ideas that reinforced the concept of absolutism, although he was against the divine origin of power, affirming that power is originated in a political contract ${ }^{19}$.

Hobbes understood that the sovereignty primary belonged to each man before the contract and started belonging to the authority created from the pact which could never be terminated. The authority from the contract is "an agent with unlimited, absolute and unquestionable power"20.

In the course of time, a conceptual change of the term sovereignty can be noticed in accordance with the forms of power organization. The idea of supreme power that was in the center of the notion of sovereignty bothered many people and thinkers who had come to disagree with this assumption to raise their voices.

Rousseau was the great contractual thinker after Hobbes, adapting the concept of pact to his own theories, but in a very different way from the English author ${ }^{21}$. To Rousseau sovereignty belongs to people. Its content is put into the legislation as an expression of general will and all power is established in favor of the governed. The function of the sovereign is to enforce laws, and this function is revocable at any time. Nevertheless, given that in Rousseau's sovereignty is the exercise of general will, it cannot be transmitted. The sovereignty is inalienable, indivisible and insusceptible to representation or limitation ${ }^{22}$.

More recently, in the early twentieth century, when discussing the legitimacy of sovereign power, Leon Duguit analyzes the issue of sovereignty making a criticism of its divine origin, which according to him, uses the omnipotence of the term the state legitimizes to abuse power since it comes from God. Duguit will redeem in Rousseau the idea that sovereignty is a will that determines itself, which has its own power and which is independent of any other will ${ }^{23}$.

\footnotetext{
${ }^{19}$ Ferrajoli, p. 16-17.

${ }^{20}$ Azambuja, 1996, p. 59.

${ }^{21}$ Rousseau, 1978.

${ }^{22}$ Id., p. 43-46. Inspired by Rousseau's speeches, the most widespread definition of sovereignty, adopted by many constitutions, is established in Europe more precisely in 1789 in the French Revolution with the Declaration of the Rights of Man and Citizen.

${ }^{23}$ Duguit, 1942, p. 150. Also, it is important to mention that Duguit deals with the impossibility of maintaining the absolutism that is referred to by the sovereign principle when it comes to international relations between States. To confirm his theory, Duguit mentions the League of Nations, which was as a "super-state" that was above all the States that adhered to it.
} 
The idea that inspired the first post-war era of the League of Nations (1919) was that it was necessary to prevent any power from triggering again another calamity in the world. Unfortunately, the way the relations between countries at that moment were designed would not allow the League of Nations to work. The concept of absolute sovereignty was still too strong.

Nevertheless, even with the failure of the League of Nations it is possible to observe a big change in international relations in the course of time. Especially after the Second World War, countries had to cede part of their sovereignty to submit to rules and legal standards of a global community, once the world had become a federation of countries. The modern State in its classical formulation of absolute sovereignty power has failed ${ }^{24}$.

Being part of international and multilateral organizations require that States cede part of their internal sovereignty, which does not imply a loss of sovereign power but enables new standards of coexistence and collaboration between States.

According to Ferrajoli, the notion of absolute power of sovereignty is diminished by the time it is sanctioned the UN Charter, in 26 June 1945 and the Universal Declaration of Rights, in 10 December 1948, approved by the UN General Assembly ${ }^{25}$. With those documents the concept of absolute sovereignty gives space to common interests of countries all around the world. The imperative of peace and the protection of human rights gain a bigger dimension in matters related to international affairs.

The international rule of law acquires a superiority status in many parts of constitutions around the world. In the meantime, one can say, as did Hans Kelsen, that the fact that the state is sovereign means that the national legal order is one over which there is no other. The only order it might seem to be superior to national law is the order international ${ }^{26}$.

This is also true in the scope of the WTO. By the time the States decide to become members of the Organization, they agree to be part of an institution where rules exist to be followed and respected. Therefore, in failing to comply with WTO law, no argument of a member regarding noninterference in domestic issues should be accepted.

\footnotetext{
${ }^{24}$ Martins, 1998, p. 13-28.

${ }^{25}$ Ferrajoli, 2002., p. 39.

${ }^{26}$ Kelsen, 2000, p. 545.
} 


\subsection{International Economic Relations: Economic Globalization}

The international trade has been for a long time one of the most important connections to the growth of the economic relations between States and enterprises all around the world. The exchange of goods and services between nations is still a strong bilateral and multilateral way of cooperation.

Trade is deeply related to the process of globalization and is, in fact, the basis of that process. Surely, in the course of time, it is possible to suggest that international trade will probably be the strongest instrument for even narrower relations between countries in the future.

As Peter Van den Bossche states in his book, the process of economic globalization is one of the defining features of today's world, "a process characterized by high levels of international trade and foreign direct investment"27.

The increase of international relations between countries has gained a considerable stimulus after the Second World War, when powerful nations had to help each other to recover from the damages caused by the war and multilateral economic organizations were created to help that process. In that moment there was a consensus among the winning countries of the need to create instruments that would ensure world peace. It was with the goal of stabilizing and maintaining peace and development in all countries of the world that the United Nations (UN) was born in 1945. But at the time of post-war and even before the creation of the UN, especially the United States advocated a position that world peace would require a coordination of economic interests and international financial cooperation.

Economic issues were the focus of interest of the Bretton Woods Conference in 1944 that created the International Monetary Fund (IMF) and the International Bank for Reconstruction and Development, better known as the World Bank, aiming to ensure international financial stability, restricting currency speculation ${ }^{28}$.

Also in the 1944 conference, the creation of an international body that regulates trade relations of countries was suggested and became known as the International Trade

\footnotetext{
${ }^{27}$ Van den Bossche, 2005, p. 02.

${ }^{28}$ The conference took place one year before the founding of the UN and was a kind of anticipation of it, but focused on economic issues. See Valls, 1997, p. 2.
} 
Organization (ITO). The ITO never got off the paper, but the General Agreement on Tariffs and Trade was born in 1947.

More comments about the Bretton Woods Conference and its developments will take place in section 2.3 of this first chapter. The Conference was mentioned in this moment because it is a remarkable event for the changes that economic globalization has experienced in the last decades.

The increase of international political, social and economic relations has caused the States to be more connected to each other and interdependent in many ways. Most of the decisions taken by States in the international level (or even in the national level) have immediate effects on their partners or on the behavior of other countries around the world.

Especially regarding economic interdependence, John H. Jackson comments that with that interdependence great wealth has come to the States immersed in the economic globalization since "goods are produced where their costs are lowest; consumers have more choices; production institutions are disciplined through competition; producers can realize the advantages of economies of scale" 29 .

Although this matter will be discussed throughout this dissertation, it is interesting to mention in following Jackson, that great vulnerability has come together with the economic interdependence of countries as:

\footnotetext{
National economies do not stay alone: economic forces move rapidly across borders to influence other societies. Government deficits in the United States can have an impact on its rate, which can push heavily indebted developing countries to the verge of 'bankruptcy'. An embargo or price rise implemented by major oil-producing nations can cause deep and frustrating unemployment, farm bankruptcies, and dramatic rises in the cost of living in the United States. A recession in one part of the world is rapidly felt in other parts $^{30}$.
}

David Held and Anthony McGrew state that the term globalization was used to denote the rapidly expanding political and economic interdependence experienced in the 1970s. That was a period, especially for Western states, when a reflection was necessary about the urgent need to rethink about political, economic and social orthodox structures that

\footnotetext{
${ }^{29}$ Jackson, 2000a, p. 6.

${ }^{30} \mathrm{Id}$, p. 6.
} 
were still governing in that moment and which were characterized by a strong separation of internal and external affairs, the internal and international relations, the regional and global exchanges ${ }^{31}$.

The effects of globalization can be felt in distinct areas of studies. For each area (cultural, politics, economics, social, etc.) the diagnosis is going to be different depending on which characteristics or strands of the process are analyzed. There is no doubt that globalization is a complex phenomenon, but for the sake of this dissertation it is only the economic aspects of globalization which will be explored, especially in what concerns international trade.

Notwithstanding, it is important to bear in mind that, as Held and McGrew say, reducing "globalization to a purely economic or technological logic is considered profoundly misleading since it ignores the inherent complexity of the forces that shape modern societies and the world" 32 .

There is no doubt that the institutions that arose from the so called Bretton Woods Agreements have given a big push to the economic relations that can be witnessed nowadays.

During the twentieth century, important international organizations were created to help dealing with all the demands of the international trade and the globalized economy. Nowadays the organizations created still have a prominent role in the multilateral scenario, such as the United Nations Conference on Trade and Development (UNCTAD), the Organization for Economic Co-operation on Trade and Development (OECD), the World Intellectual Property Organization (WIPO), and of course the WTO.

Also, a number of bilateral and regional agreements have been signed in the last decades, creating a parallel movement with the international organizations. According to the data of the WTO, as of 15 January 2012, 511 (five hundred and eleven) regional trade

\footnotetext{
${ }^{31}$ Held; Mcgrew, 2003, p. 9.

${ }^{32}$ Id., p. 6. Although the acknowledgement that the theory of globalization and interdependence is the basis of international relations of the present time, this dissertation does not have the aim to delve into the myriad of theories surrounding the concepts of globalization and interdependence, once they are not the focus of the proposed problem, instead, the focus of this work is to give a brief overview of the subject in order to address their importance and to pave the general panorama for the discussions that will follow.
} 
agreements were notified to the $\mathrm{WTO}^{33}$. All the agreements, despite being inspired by political or social reasons, survive and become stronger due to economic reasons.

Although protectionist practices have emerged right after the Second World War, since the institution of GATT protectionism gave way to gradual market liberalization and more remarkably in the last two decades, international relations have quickly multiplied on the basis of economic and commercial relations between international companies as the exchange of products and services between States are becoming easier and, to a great extent, are being facilitated and disciplined by multilateral rules emanated from the WTO.

International trade is the basis for the so-called economic globalization that encompasses free movement of services and foreign direct investment. Following the concept given by Joseph Stiglitz, the economic globalization is understood as a closer integration of States, its companies and its citizens, with great reduction of costs of both transportation and communication, "and the breaking down of artificial barriers to the flow of goods, services, capital, knowledge, and (to a lesser extent) people across borders" ${ }^{34}$.

One of the very positive aspects of the economic globalization and trade liberalization is the increase of capital flows from developed countries to developing countries giving these more opportunities for future growth through the global capital markets and direct investments, the facilitation on communication through the great improvement of internet-based satellite communication, and the lower prices of international transport of people.

Those are some examples that generally characterize the process of economic globalization. They are understood as the driven forces of the process as it is expected that trade expansion will create additional demand for finance, transport and communication, whereas improvement in the latter areas will make trade more efficient ${ }^{35}$.

Although the term globalization can be studied from a number of different perspectives, it is broadly understood that the process of globalization is intimately connected to economic subjects. The International Monetary Fund assimilates the concept of

\footnotetext{
${ }^{33}$ Not all the 511 regional trade agreements are in force currently. For up-to-date information on the agreements in force, see: < http://rtais.wto.org/UI/PublicAllRTAList.aspx $>$.

${ }^{34}$ Stiglitz, 2002, p. 9.

${ }^{35}$ United Nations Economic Social Commission for Asia and the Pacific, Globalization: opportunities and challenges, p. 5-7. Published online at: <http://www.unescap.org/pdd/publications/regcoop/ch1.pdf $>$. Accessed in: 11 Jan. 2011.
} 
globalization as the "growing of economic interdependence worldwide through the increasing volume and variety of cross-border transactions in goods and services and of international capital flows, and also through the more rapid widespread diffusion of technology"36.

With the trade facilitation enabled by a greater exchange of goods and services between countries, lower tariffs on products, economic and industrial integration, the process of globalization allows a better division of labor and a more efficient allocation of savings at the same time as it raises productivity and average living standards ${ }^{37}$.

Once everyone around the world feels the effects of the process of economic globalization and trade liberalization, the discussions about those subjects can be quite emotionally charged. Of course, the effects of the process are not the same for everybody or every country, so it is clear that economic globalization is not felt (perceived) in the same way around the world.

Economic globalization and international trade are movements that have been designed to serve a multilateral context since the institution of GATT in 1948. Notwithstanding, countries around the world are significantly different in terms of wealth, social and economic development; moreover, it can be said that the process of economic globalization has increased the gap between developed and developing countries.

As Peter Van den Bossche states, "economic globalization and international trade currently gives rise to problems and tensions in developed as well as developing countries" ${ }^{\prime 38}$. Indeed, it can be said that the economic globalization as a whole may adversely affect different segments of society.

In the same stream, Robert Gilpin observes that many aspects of globalization that are discussed at the present time are not new and the great majority of citizens are excluded of the process. He also states that despite the importance of economic globalization, it is a limited process "and cannot possibly possess either all negative or all the positive consequences attributed to it" 39 .

\footnotetext{
${ }^{36}$ International Monetary Fund, Globalization: Opportunities and Challenges, in World Economic Outlook, May 1997, p. 45.

${ }^{37}$ Id., p. 45.

${ }^{38}$ Van den Bossche, 2005, p. 14.

${ }^{39}$ See Gilpin, 2000, p. 295-296
} 
Especially with the incentive given to economic globalization in the last two decades, the whole global society had to adapt to the fast changes that have been made in terms of culture, communication, transports, exchange of goods, capital flows, transnational services, to name but a few. The great majority of those changes are positive, but not all countries were or are ready for them in economic terms, a fact that can lead to difficult problems and tensions.

According to Dani Rodrik there are some explicit problems in the process of globalization. The author states that:

The process that has come to be called 'globalization' is exposing a deep fault line between groups who have the skills and mobility to flourish in global markets and those who either don't have these advantages or perceive the expansion of unregulated markets as inimical to social stability and deeply held norms ${ }^{40}$.

Indeed the international trade designed with GATT and nowadays under the responsibility of the WTO has little connection with fair trade. Instead, the economic globalization that surrounds international trade has delivered much more privileges to developed countries than to developing and the least developed countries around the world.

Although the speech of the defenders of the globalized economy and the international trade normally addresses the liberalization of trade as a win-win game, that is not true, especially for the poorest countries that joined the multilateral trading system. Actually, as Joseph Stiglitz has argued, the GATT rounds were very unfair to developing countries (and the same is happening with WTO rounds $)^{41}$.

One assumption of this dissertation is that the problem is neither trade liberalization, nor economic globalization, but instead how these processes are being implemented along the years. It is not only monetary or financial issues that separate developed countries from developing and least developed countries, the differences go beyond those issues and are clearly reflected on the deployment of disputes of developing countries complaining against developed countries before the WTO dispute settlement body.

\footnotetext{
${ }^{40}$ Rodrik, 1997, p. 2

${ }^{41}$ See Stiglitz, 2006.
} 
More than that, Stiglitz states that it is not only a disparate relation in resources between countries that separates them, but a disparate relation in knowledge as well. That is one of the reasons, among others, why liberalization of trade has been very asymmetric ${ }^{42}$. Specially economic and capacity differences should be taken seriously into consideration and carefully treated in the process of trade liberalization.

There are big differences between developed, developing and least developed countries that can be detected with a glance at a newspaper. It is not the goal of this dissertation to have a deep discussion about aspects other than economic, but each society around the world has different problems and, especially comparing societies from rich countries with societies from poor countries, those problems can have a considerable difference.

Complementing that, Stiglitz argues that there are asymmetries that are natural. To illustrate the panorama and using the example given by Stiglitz, if the United States subsidizes cotton (it actually happens), this action by an enormous economy like the United States harms all the developing countries around the world that produce cotton. But, on the other hand, if Cambodia subsidizes some sort of commodity, it does not affect the global market at all given the small market share that Cambodia has. That is one of the main reasons why developing countries should be given special conditions in pursuit of their policies; otherwise they will never be able to compete with rich countries ${ }^{43}$.

Since the discussion on economic asymmetry is going to be the background of the whole dissertation, it was just a briefly introduced in this section so as highlight what is important to the proposed reflection.

Before proceeding to the specific explanation of the multilateral system as such, the concepts regarding economic development that were already used in this section and that will be repeated throughout the dissertation amount to the ambition that (a) developed country economies; (b) developing economies and, (c) least-developed economies, will be treated uniformly converge. For the WTO there is no definition for developed or developing countries. When countries sign to enter the Organization they declare themselves as

\footnotetext{
${ }^{42}$ Ibid.

${ }^{43}$ Ibid.
} 
developed or developing countries. Among the current 153 members, 31 were declared as least-developed countries (LDCs) by the United Nations ${ }^{44}$.

Without the intention of entering the sphere of the literature regarding economic development or for the sake of consistency, this dissertation will accept the status of development of the WTO members in accordance with what is accepted by the Organization. Also, whenever a rule or a statement can be applied both to the developing and to the leastdeveloped countries, this dissertation will refer to these countries as developing countries interchangeably unless otherwise stated.

\subsection{The emergence of the Multilateral Trading System: history and evolution since GATT}

So as to discuss the multilateral trading system it is necessary to bring elements from the history and evolution of international trade, especially taking into account the events that happened after the Second World War and the creation of the international organizations that these events triggered.

Before addressing those post-war events, it is worth highlighting the fact that the international economic relations under international law are primarily governed by treaties, rather than by customary law ${ }^{45}$. Those treaties - as the one that established the WTO - are in many cases responsible for the institution of an international organization.

Indeed and as noted by Jackson in one of his books, in all the governmental international organizations that are listed in the Yearbook of International Organizations, there are more than three hundred that are related to economic matters ${ }^{46}$.

As mentioned in the previous section, it was in the Bretton Woods Conference in 1944, which took place in New Hampshire, the United States (US) that the economic issues

\footnotetext{
${ }^{44}$ More clarification on the criteria for identification of LDCs can be found at: <http://www.un.org/specialrep/ohrlls/ldc/ldc\%20criteria.htm>. Accessed in: Jan. 2011.

${ }^{45}$ Jackson, 2000a, p. 32.

${ }^{46}$ Id., p. 32. Jackson makes a distinction between the different international economic organizations, dividing them into five categories: the general economic institutions, as the WTO; the other United Nations specialized agencies, which tend to focus on particular problems or sectors of endeavor, such as the Food and Agriculture Organization; the regional organizations, as for example the European Union; the international commodity agreements and; more specialized organizations, as the World Customs Organization. Id., p. 32-33.
} 
where discussed after the war and that the need for an international organization on trade was recognized. Among the important results of the Conference, are the charters of the IMF and of the World Bank (International Bank for Reconstruction and Development). Also in that Conference problems involving international trade were discussed, but the Conference did not recognize the need for a comparable international institution to deal with trade issues and to complement the IMF and the World Bank.

That would have been the ITO, which should be created to complete the framework of the big international economic organizations, and that should take care of trade openness in order to overcome the protectionism that resulted from the 1929 crises and that in the following decade had an impact on political tensions thus contributing to the outbreak of World War II ${ }^{47}$.

A Preparatory Committee was established in February 1946 to work on the founding document for an international organization for trade. The first meeting took place in London and the work followed a proposal by the United States entitled Suggested Charter for an International Trade Organization ${ }^{48}$.

As Jackson explains, the work initiated in London continued in Geneva from April to November 1947, where meetings were held in a Conference divided in three main parts:

One part dealt with continuing the preparation of a charter for a major international trade institution, the ITO. A second part focused on negotiating a multilateral agreement to reciprocally reduce tariffs. A third part concentrated on drafting the 'general clauses' of obligations relating to the tariff obligations. The second and third parts, together, would constitute the General Agreement on Tariffs and Trade ${ }^{49}$.

Although there was a great improvement on negotiations in Geneva concerning the GATT provisions, there was a failure to agree on the ITO Charter.

The twenty three countries that were active in the negotiations of GATT from 1 January 1948 decided to apply the GATT through the 'Protocol of Provisional Application of

\footnotetext{
${ }^{47}$ Lafer, 1999, p. 29.

${ }^{48}$ Van den Bossche, 2005, p. 79.

${ }^{49}$ Jackson, 2000a, p. 37.
} 
the General Agreement on Tariffs and Trade' (PPA), previously adopted on 30 October $1947^{50}$.

Then, in March 1948, in Havana, the negotiations on the ITO Charter were successfully completed. According to Peter Van den Bossche, "the Havana Charter provided for the establishment of the ITO, and sets out basic rules and disciplines for international trade and other international economic matters" ${ }^{\circ 1}$.

Despite being very active in negotiations, the United States Senate did not give its advice and consent to ratification on the Charter Establishing the International Trade Organization. No one would want to establish an international trade organization without the participation of the leading economy nation in the world ${ }^{52}$.

\subsubsection{GATT and its developments until 1994}

The ITO Charter never came into force. Notwithstanding, GATT was considered a valid commitment under the scope of International Law through the PPA. This Protocol had as it most important impact its statement of the manner of implementing GATT.

As explained by Jackson, Part I of GATT contained the Most Favored Nation principle, which will be better explained in section 2.3 as it is still one of the basic principles of the multilateral trading system, and the tariff concession obligations. Part II (Articles III to XXIII) contained most of the main substantive obligations including customs procedures, subsidies, antidumping, quotas and national treatment. And Part III contained mainly procedural rules ${ }^{53}$.

Regarding the important obligations (most of them situated in Part II), the GATT's contracting parties were entitled grandfather rights applicable to any provision of the

\footnotetext{
${ }^{50}$ Van den Bossche, 2005, p. 80.

${ }^{51}$ Id., p. 80.

52 See Jackson, 2000a, p. 37.

53 Jackson, 2000a, p. 40. See also Hoekman, Kostecki, 2002, p. 37. The creation of the GATT was much more complicated, even from a legal perspective. The intention here is to just give an overview of the historical, economic and political establishment of the GATT.
} 
contracting party legislation by the time it became a party, and that was inconsistent with GATT Part II obligation ${ }^{54}$.

On the other hand, GATT contracting parties must accept the tariff concessions of Article II of GATT as they must also fully respect the Most Favored Nation (MFN) obligation of Part I ${ }^{55}$. The MFN became one of the basic and most important principles of the WTO after 1994 together with the principle of national treatment. As Theresia Schnell states, "the substantive norms of the GATT are non-discrimination, reciprocity, and the right to take 'safeguard' action" 56 . As those principles/norms are part and guide the multilateral system established by the WTO, they are going to be given attention later on in a separate section of this chapter.

The international trade negotiations under the scope of GATT were performed in eight rounds, where nations interested in reducing barriers to trade got together in meetings adopting the precepts establish by GATT.

In the course of time, both the nations interested in participating in GATT meetings and the volume of trade increased significantly. As Van den Bossche points out, although the GATT was not conceived as an international organization, (rather it was conceived as a multilateral agreement for the reduction of tariffs), it gained importance and transformed itself over the years into a de facto international organization ${ }^{57}$.

GATT was very successful in reducing tariffs on trade in goods. Indeed, Vera Thorstensen explains that in 1947 the average import tariff was of 40\% while in 1994 that average dropped to $5 \%{ }^{58}$. The contracting parties adopted the methodology of rounds of meetings for the negotiation of tariffs reduction and trade liberalization. There were eight Tariff Rounds during the period of GATT (from 1947 to 1994) ${ }^{59}$.

\footnotetext{
54 This grandfather rights exception (also called 'existing legislation exception' allowed most governments, "which would otherwise need to submit the GATT for legislative approval, to approve the PPA by executive or administrative authority without going to the legislature". Jackson, 2000a, p. 40.

55 Id., p. 41.

${ }^{56}$ Schnell, 2004, p. 5

${ }^{57}$ Van den Bossche, 2005, p. 81.

${ }^{58}$ Thorstensen, 1999, p. 30.

59 The eight rounds were the following: Geneva Round 1947; Annecy Round 1948-49; Torquay Round 1950-51; Geneva Round1955-566; Dillon Round 1960-62; Kennedy Round 1964-67; Tokyo Round 1973-79 and; Uruguay Round 1986-94. See Koul, 2005, especially the first chapter.
} 
So as to give an idea of the importance that GATT gained, twenty-three countries became the original contracting parties of the Agreement and the negotiations covered roughly 45,000 tariff concessions and U\$ 10 billion of trade in the Geneva Round of 1947. Approximately three decades later, the Tokyo Round (1973-79) (the seventh round) involved 102 countries and U\$ 300 billion of trade ${ }^{60}$.

Notwithstanding, the evolution of multilateral trade liberalization did not happen in a linear way, among other reasons, because bilateral and regional trade agreements were created. The most important agreement of that period was the creation of the so-called Economic European Community that established a common internal market with a common external tariff ${ }^{61}$. Moreover, as Prazeres reminds us, in 1970 the world economy suffered a deep crises that included the reduction of the rate of expansion of international trade ${ }^{62}$.

Actually, after the Tokyo Round the international economic scenario experienced a very slow economic growth, completely different from previous years of tariff negotiations. Rapid inflation and high unemployment characterized the diagnosis of the economic stagflation of that moment.

Nevertheless, as Koul states, the Tokyo Round was successful as it "made nontariff barriers visible if not eliminated and also decreased the uncertainties generated by governmental interventions in the markets as well as stabilized the international trading environment" ${ }^{\prime 3}$.

Due to the importance acquired by GATT in matters related to international trade, there was a latent need for an institution, an international organization to deal with the subjects under the scope of GATT. Despite that need (and making it clear that there was no intention to create an international organization when the Uruguay Round started), there was an increasing interest to involve other topics in the GATT discipline, such as trade in

\footnotetext{
${ }^{60}$ Koul, 2005, p. 15.

${ }^{61}$ As of 1950, the "European Coal and Steel Community" begins to unite European countries economically and politically. The six founders, for which a common external tariff was first established are: Belgium, France, Germany, Italy, Luxembourg and the Netherlands.

${ }^{62}$ See Prazeres, 2009, especially the first chapter,

${ }^{63}$ Koul, Op. Cit., p. 19.
} 
agricultural products, trade in textiles and clothing, trade in services and intellectual property rights $^{64}$.

Those interests were present in the broad mandate of the Punta del Este Declaration, in 1986. As Jackson shows, included in the list of negotiations were:

[...] bringing agricultural goods trade under GATT discipline (a problem that had persisted throughout the history of GATT but that had resisted reforms in the two precious negotiating rounds); elaborating further on the rules regarding subsidies beyond that of the Tokyo Round Code; bringing attention to the troublesome textile protectionist-type arrangements that existed uneasily in the GATT context; and a number of other issues ${ }^{65}$.

It is clear that the subjects that were included in the agenda for the Uruguay Round were not chosen randomly. The United States had a strong interest in the inclusion of trade in services and intellectual property rights as well as in the liberalization of trade, as those were sectors that were gaining importance in international economy, and, at the same time, agricultural issues were interesting to get the attention and to stimulate developing countries to participate in the discussions.

Another issue that was becoming more important and that needed to be taken into account was the system of dispute resolution. The dispute settlement system of GATT was one of its most worrying defects, and with the purpose of reviewing it, a special negotiating group that would focus on the dispute settlement rules was established. More attention is dedicated to this in the next section.

Among the other problems of GATT, Barral points out the GATT à la carte, meaning the possibility that each contracting party had to choose the specific agreement that they wished to join and the grandfather rights, allowing parties to rely on pre-existing domestic rights ${ }^{66}$.

Despite the problems verified in the GATT structure and proceedings, its importance to the liberalization of international trade and the improvement of a global

\footnotetext{
${ }^{64}$ Jackson points out that "the European Community was hesitant to pay attention to trade in services, but later it began to realize the importance of this for many European Community member states (...). Some developing countries were extremely concerned about norms that would protect intellectual property at the expense of developing country needs". Jackson, 2000a, p. 44.

${ }^{65}$ Ibid.
} 
economy is evident. Yet, the experience acquired during the years before the institutionalization of an international organization for trade was substantially important to delineate the goals and the needs of the WTO.

Actually, the quite successful dispute settlement system of the WTO, despite its many problems, especially in the implementation phase, was structured from the observation of the failures and the necessary changes in the GATT system.

\subsubsection{Dispute Settlement in the GATT}

The draft of the ITO Charter originally established a strict dispute settlement system, which contemplated the effective use of arbitration (not always mandatory), and also the possibility of appellation to the International Court of Justice in some cases ${ }^{67}$.

According to Jackson, the proposed model of dispute settlement to GATT could be expressed in three main characteristics: first the possibility of conviction in case of nullification or impairment; second, the power of contracting parts not only to investigate or recommend an action, but also to require a determinate behavior; and third, the possibility that the country could be authorized to suspend its GATT's obligation within other contracting $\operatorname{parties}^{68}$.

The system of the GATT dispute settlement contained two articles, which basically foresaw the possibility of (i) consultations concerning representations that any other contracting party can do when they refer to the application of customs regulations and formalities, the anti-dumping duties and countervailing measures, quantity regulations and exchange rates, subsidies, trade operations to the State, among others, and (ii) protection of advantage, if a contracting party considers that any advantage accruing to it, directly or indirectly, of this Agreement is being nullified or reduced, or that one of the objectives of the Agreement is being impeded.

In the first decade of the GATT, disputes were resolved by diplomatic means exclusively, consultation about violations and work in working groups formed by members of

\footnotetext{
${ }^{66}$ Barral, 2000, p. 25.

${ }^{67}$ Jackson, 1998b, p. 6.

${ }^{68}$ Id., p. 7.
} 
the governments of the contracting countries. Basically what was done were negotiations outside of court or arbitration.

There was a substantial change in this framework in the 1950s. A review was conducted of the Agreement and numerous provisions of GATT regarding dispute settlement were changed in 1955. It was decided, for example, that working groups would be replaced by panels of experts acting as experts and not as members of the countries ${ }^{69}$.

But it was in the Tokyo Round that most promoted trade liberalization with the reduction in tariffs on a trade volume of U\$ 300 billion, that some real initiatives to improve the dispute settlement procedure were taken into account, under the supervision of the Group Framework Committee. However, according to Jackson, the effort to change procedures for dispute settlement partially failed, in part because of the strong objection from the European Community (EC). In any case, the result was the adoption in 1979 of an instrument called Understanding on Notification, Consultation, Dispute Settlement and Surveillance ${ }^{70}$.

That Understanding explains the procedures for dispute settlement in GATT. However, despite the demonstrations in order to improve the dispute settlement procedure, the Understanding of 1979 was well below the expected trend ${ }^{71}$.

In the body of that Understanding it was basically stated that the party could require a consultation to the GATT as a first step, and then should provide recognition of a conciliation agreement to the General Director of GATT. If a solution was not reached, the party could then require the formation of a panel. The panel would then make its report and submit it to the Council of Representatives, which was the permanent organ of the GATT. Note that this Council was not provided or standing in the text of the GATT, but it was established from the practice and decisions of the contracting parties ${ }^{72}$. Also because of practice, it was decided that if the Council approved the report by consensus, it became mandatory. If it was not approved, the report would not have binding effect.

A major problem with the procedure of the GATT dispute settlement was exactly the consensus of the Council, which was "composed of all members in two key phases of the

\footnotetext{
${ }^{69}$ Jackson, 1998b, p. 8.

${ }^{70}$ Jackson, 1998b, p. 9.

${ }^{71}$ Id., p. 10.

${ }^{72}$ Id., p. 09.
} 
process: (i) the establishment of the panel, and (ii) the approval of the panel's report"73. Since all the GATT contracting parties were part of the Council, that means that the State convicted - that should obey and implement the panel's decision - was included. By the consensus rule the loser State could block consensus raising objections to it. Clearly this rule was one of the biggest flaws of the system of the GATT dispute settlement.

At the Ministerial Conference in 1982, between the Tokyo Round and the Uruguay Round, the discussion about the problems of procedure of the GATT dispute settlement became one of the major worries of the system, given the general dissatisfaction of the contracting parties. During this ministerial conference, the States gave special attention to the issue of developing and encouraging a new trade round. Nevertheless, according to Jackson, the discussion advanced little ${ }^{74}$. The final document of this conference suggested the need to withdraw the rule of consensus to approve the panel's report, so that the State convicted could not block or delay the approval.

However, later practices that occurred after the resolution of 1982 did not reveal any change. Due to the lack of progress regarding the procedure for settling disputes, the issue was included in the Declaration of Punta del Este, to be discussed in the eighth round of GATT negotiations, the Uruguay Round.

During the 1980s, according to Jackson, while the procedure was becoming more legally precise, the idea that there were two types of cases in the GATT was developed: the cases of violation and certain cases of "non-violation", consisting in cases not involving a breach, but a "nullification or impairment"75.

Actually, GATT article XXIII.1 on "nullification or impairment" states:

1. If any contracting party should consider that any benefit accruing to it directly or indirectly under this Agreement is being nullified or impaired or that the attainment of any objective of the Agreement is being impeded as the result of

(a)Failure of another contracting party to carry out its obligations under this Agreement; or

(b) The application by another contracting party of any measure, whether or not it conflicts with the provisions of this Agreement; or

\footnotetext{
${ }^{73}$ Barral; Prazeres, 2002, p. 31.

${ }^{74}$ Jackson, 1998b, p. 10.

${ }^{75}$ Id., p. 10.
} 
(c) The existence of any other situation ${ }^{76}$.

The first objective of the GATT 1947 system, embedded by the WTO dispute settlement system in 1994, is the withdrawal of illegal measures under article XXIII. This objective has strong connection with the theory of international responsibility of States briefly reviewed in this chapter, and is in line with the obligations set out in international public law to cease the illegal act and remedy the damage eventually caused.

Still, in article XXIII.2, the possibility of suspension of obligations and retaliation under GATT (those provisions are also present in the Dispute Settlement Understanding of the WTO) is already provided, with a special difference for international economic relations, which is limiting the right of unilateral retaliation unless it was approved by all contracting $\operatorname{parties}^{77}$.

So as to make a little reflection on this, and as analyzed by Petersmann, it is interesting to observe that article XXIII.2 excludes the right of unilateral suspension of GATT obligations without the approval of the other contracting parties which is different from what is proposed in article 60 of the Vienna Convention on Law of Treaties that understands that a material breach of a multilateral obligation entitles the affected party to suspend, in whole or in part, the application of the treaty to the offending country ${ }^{78}$.

Various aspects of the GATT dispute settlement system were included in the worries mentioned by the contracting parties during the Uruguay Round. Among the problems of the system, there were delays in the establishment of panels and in the adoption of panel report, the increase in non-compliance with dispute settlement rulings and incomplete or conditional implementation of dispute settlement findings, and the lack of transparency of GATT dispute settlement proceedings ${ }^{79}$.

Indeed, Jackson also describes what he meant by the major failures of the GATT system, namely: (i) vague language, with few details of objectives and procedures, (ii)

\footnotetext{
${ }^{76}$ See GATT 1947.

${ }^{77}$ Petersmann explains that "the drafting history of Article XXIII:2 confirms that it was designed to limit the customary law right of unilateral reprisals, whose exercise had contributed so much to the 'law of the jungle' in international economic affairs during the 1930s [...]". Petersmann, 1997, p. 82.

${ }^{78}$ Ibid. See also article 60 of the Vienna Convention on Law of Treaties on 'Termination or suspension of the operation of a treaty as a consequence of its breach', 1969. Published online at: < http://untreaty.un.org/ilc/texts/instruments/english/conventions/1_1_1969.pdf>.

${ }^{79}$ Petersmann, Op. Cit., p. 90-91.
} 
inaccuracy of the power of the contracting parties with regard to oversight of dispute resolution process, (iii) the potential to block the adoption of the panel charged by the state, (iii) second possible blocking, more serious than the first, in which the convicted State could block and prevent the adoption of the report agreed by the Council of Representatives, the rule of "consensus ", since it was also part of the Council, (iv) the fragmentation of the procedures for dispute settlement because of the existence of various procedures, and (v) the pressure from government contractors on the panel members ${ }^{80}$.

Despite the problems of the dispute settlement procedure of the GATT, it was an important system well admired because various interests of trade policy were submitted to it ${ }^{81}$. Yet, as an example of its importance, Jackson points out that the free trade agreement between Canada and the United States of 1988, now North American Free Trade Agreement (NAFTA), has taken many provisions of its dispute settlement system from GATT provisions $^{82}$.

Moreover, all the provisions established during the period of GATT were recognized and embedded in the WTO dispute settlement system. Although changes were made in an attempt to make the system more effective and transparent to ensure a certain level of legal security for the WTO members, the precepts of GATT 1947 are present and are taken into account in the decision making process at the Organization.

\subsubsection{Changes in 1994: the WTO institutional framework}

This section is dedicated to the institutional framework of the WTO since it is assumed that for a better understanding of the multilateral trading system (and of the problem of this dissertation) it is necessary to understand the nature of the rules that will be dealt with. As Douglas North has explained, institutions play a considerable role in the development of society and therefore they have significant influence on economic development. According to

\footnotetext{
${ }^{80}$ Jackson, 2000a, p. 135.

${ }^{81}$ Jackson, 1998b, p. 13.

${ }^{82}$ Jackson, 2000a, p. 135.
} 
the author, institutions are the rules of the game, the limitations that provide conditions for exchanges, be it of a political, social or economic ${ }^{83}$ nature.

After almost fifty years of negotiations under the scope of the GATT 1947, the WTO was established on 1 January 1995, as a result of the efforts of the contracting parties of the GATT and in line with the needs to increase the international exchange of goods, services, international investments and the greater importance of intellectual property rights.

At the Conference in 1994 in Marrakesh a conclusion was reached for the Uruguay Round initiated in 1986 in Punta del Este. Among the most important results of that round were, of course, the institution of the WTO signed by 129 countries and the achievement of a considerable reduction in tariffs for industrial goods. The Marrakesh Agreement instituted the WTO and encompasses the GATT, with the modifications made by the Uruguay Round, all agreements and arrangements concluded under its scope and the complete results of the Uruguay Round.

Among the main results of the Uruguay Round a number of Agreements established for specific sectors of economic affairs can be mentioned: the Agreement on Trade in Services (GATS), the Agreement on Investment Measures Related to Trade (TRIMs), the Agreement on Textiles and Clothing, the agreement on Trade-Related Aspects of Intellectual Property Rights (TRIPS) and a revised Dispute Settlement Understanding (DSU).

The institution of an international organization established by a treaty under international law changes the kind of commitments that States assume when they decide to be part of it. It is important to stress the fact that GATT was not a formal international organization, but an intergovernmental treaty ${ }^{84}$. For this reason, as Hoekman and Kostecki state GATT did not have members but contracting parties, and that changed completely when WTO was instituted ${ }^{85}$.Yet, that means that GATT did not have the power to discipline the behavior of signatory countries, making the negotiations much more difficult, especially when dealing with dispute resolution, whose contracting parties could exercise a lot of pressure upon panel members.

\footnotetext{
${ }^{83}$ See North, 1990.

${ }^{84}$ For further reflection see Ridruejo, 1994, p. 819.

${ }^{85}$ Hoekman; Kostecki, 2002, p. 37.
} 
Indeed, the WTO differs from GATT in many important aspects. While GATT was a relatively flexible institution, the WTO establishes rules that are applicable to all members, and all members are obligated to respect the dispute settlement proceedings ${ }^{86}$.

With the development of international trade and the expressive increase of the number of GATT contracting parties, which had the participation of only 23 countries in the first round and entered the Uruguay Round with the participation of 123 countries, clearly it was necessary to deliver a more legalistic character to the future international trade organization $^{87}$. Actually, the possibility of imposing punishment for the breach of its rules make the WTO a very peculiar organization as is going to be suggested in chapter $2^{88}$.

The legal framework resulting from the Uruguay Round Agreement is well understood when looking at its table of contents. The WTO chapter itself contains only ten pages, but the WTO agreement embraces, besides these ten pages, four extremely important annexes. Annex 1 contains the multilateral agreements which are mandatory for all members and is divided into three parts: the GATT 1994 and its agreements, the GATS and issues related to intellectual property. All members should also be required to accept the Annex 2 (Understanding on Dispute) and Appendix 3, which refers to the mechanism for review of trade policy (trade policy review) ${ }^{89}$. Annex 4, somehow less important, refers to plurilateral agreements, which are not mandatory.

In the structure of the Organization, the highest level of the WTO is occupied by the Ministerial Conference, composed by representatives of all members - nowadays the WTO has 153 members -, which shall meet at least once every two years. The Ministerial Conference has an extremely important role, since it has the authority to take decisions on all matters under the scope of any of the multilateral trade agreements ${ }^{90}$.

\footnotetext{
${ }^{86}$ Hoekman, 2002, p. 41.

${ }^{87}$ According to Hudec, from the 23 original members of GATT, ten were developing countries: Brazil, Burma, China, Ceylon, Chile, Cuba, India, Pakistan, Syria and Lebanon. In the late 1950s, the number of developing countries continued to be minority, with 16 contractors. Only during the 1960s this situation changed: seven major developing countries joined the GATT, and the number increased to 36. A great wave of accession of the colonies, once their independence came in the 1970s, made that from the 77 contracting parties that were joining the agreement, 52 were developing countries. Between the years 1970 and 1987, the number of GATT contracting parties continued to grow and, with the exception of Romania and Bulgaria, all new contractors were developing countries. See Hudec, 1987, p. 23-24.

${ }^{88}$ See Barral; Prazeres, 2002, p. 28.

${ }^{89}$ Jackson, 2000a, p. 49.

${ }^{90}$ The structure of the WTO
} 
Actually, the Ministerial Conference works as a supreme body in the structure of the WTO, and among the decisions that it has the power to make are the power of appointing the Director-General and adopting staff regulations; granting waivers; decisions on accession; adopting amendments and adopting authoritative interpretations on WTO agreements ${ }^{91}$.

In the hierarchy of the WTO, right below the Ministerial Conference there are the General Council, the Dispute Settlement Body and the Trade Policy Review Body. The General Council is composed by representative of all members that shall meet as appropriate (normally once every two months) in the intervals of the Ministerial Conference ${ }^{92}$.

The Dispute Settlement Body and the Trade Police Review Body are two emanations of the General Council. Although both have their own Rules of Procedure and have always had a different Chairperson, they are intimately connected to the General Council. Actually, when the General Council deals with the trade policy review mechanism, it convenes and acts like the Trade Policy Review Body; on the other hand, when the General Council administers WTO dispute settlement, it acts as the Dispute Settlement Body ${ }^{93}$. As relating to the Dispute Settlement Body, a detailed explanation of its rules and proceedings shall be carried out in Chapter two of this dissertation.

Following the structure of the WTO, Article IV:5 of the WTO Agreement states that at the level below there are specialized councils that shall operate under the guidance of the General Council: the Council for Trade in Goods, the Council for Trade in Services and the Council for TRIPS.

The Council for Trade in Goods shall oversee the activities and the functioning of the Multilateral trade Agreements in Annex 1A, which include: the GATT 1994, Agriculture, Sanitary and Phytosanitary Measures, Textiles and Clothing, Technical Barriers to Trade, Trade-Related Investment Measures, Anti-Dumping, Customs Valuation, Preshipment Inspection, Rules of Origen, Import Licensing, Subsidies and Countervailing Measures and Safeguards. The Council for Trade in Services shall oversee the functioning of the General Agreement on Trade in Services (GATS) - Annex 1B - and, finally, the Council for TRIPS shall oversee the functioning of the Agreement on TRIPS - Annex 1C.

\footnotetext{
${ }^{91}$ See WTO Agreement., especially Articles VI, IX, X, XII.

92 The WTO document WT/L/161 brings the information of the Rules and Procedures of the General Council.

${ }^{93}$ Van den Bossche, 2005, p. 126.
} 
The detailed structure of the WTO is a result of a large work during the last GATT trade negotiations round. Among the important achievements of the Uruguay Round, the ones that play a major role for the purpose of the present work are the achievements related to intellectual property, the dispute settlement system and the integration of developing countries.

Actually, the TRIPS Agreement is considered an impressive acquisition for the multilateral trade system and brings substantial new international rule discipline to complement the protection for patents, copyrights, trade secrets and similar intellectual property subjects as is going to be reviewed in more detail in Chapter two.

In what refers to developing country integration, as Jackson states, the system of 1994 by bringing a rule discipline to the trade policies for new industrializing countries proportions a more comprehensive integration of developing countries than before, "given the requirement that all countries have tariff and service schedules, and the narrowing of certain less developed country exceptions" ${ }^{94}$.

Finally, in addition to the specialized councils, the agreement of the WTO in Article IV:7 sets a number of committees and working parties that assist the General Council and the Ministerial Conference such as the important committees on Trade and Development and the Committee of Budget, among others.

Before moving on to the objectives and principles of the WTO, it is important to note that despite the new structure of the WTO being much more developed organizationally and normatively than the GATT, it is explicit that the WTO shall be guided in its the decisions, procedures and practices by the work of GATT ${ }^{95}$. Moreover, GATT's history is an important element for the interpretation and understanding of the WTO as an institution and the GATT still exists once it is embedded in Annex 1A of WTO Agreement.

\subsection{WTO: objectives and principles}

The WTO was created from a necessity of the contracting parties of the GATT of having instituted an international organization for trade, where they could deal with trade

\footnotetext{
${ }^{94}$ Jackson, 2000a, p. 3.

${ }^{95}$ See Article XVI: 1, GATT.
} 
matters within legal security and stability on the rules and proceedings related to international trade matters. With the aim of establishing a fairer trade and increase the economic development of all the members, from the preamble of the Marrakesh Agreement it is recognized that multilateral trade relations should be conducted with a view to raising standards of living and ensuring full employment by expanding the production of trade in goods and services.

With the aim of promoting development in a sustainable way, members should make sure of an optimal use of the world's resources paying attention to environment preservation and including all members in a manner consistent with the concerns at different levels for the economic development of its members.

Indeed, the agreements made under the scope of the WTO should be directed to the substantial reduction of tariffs and other barriers to the liberalization of trade and to the elimination of differential treatment ensuring that they are reciprocal and mutually advantageous to all members. Also, positive efforts have to be made to the inclusion of developing and least developed countries in the share of the growth of international trade taking into account their special needs.

As it is, the endeavor of including all members in the share of the liberalization and improvement of the international trade and economic globalization is reflected in the principles of the WTO.

Most of the principles were already guiding the negotiations during the GATT period and were embedded in the Organization in 1994. Although a list of principles in WTO agreements cannot be found, they are the cornerstones of multilateral trade system. Also, since they are organized in different fashions in the literature some of the principles with greater importance for this study will be presented in greater detail.

\subsubsection{Most-Favored-Nation Treatment}

The Most-Favored-Nation treatment (hereinafter MFN) is understood, together with the principle of the National Treatment, as the basic principles of non-discrimination of the GATT 1947 that were incorporate by the WTO, and are specifically present in the GATT 
1994 Agreement, GATS and TRIPS Agreement. Also, this principle is reproduced in a number of bilateral and other trade agreements.

The MFN treatment in the GATT refers to an obligation of equal treatment, which means that any favorable treatment addressed to any country with respect to imports and exports of products has to be extended to the other members of the agreement. It means, as Jackson emphasizes, "an obligation to treat activities of a particular foreign country or its citizens at least as favorably as it treats the activities of any other country"96.

Jackson points out that the MFN clause dates to the twelfth century, although it became more famous and utilized in international trade with the growth of commerce in the fifteenth and sixteenth centuries. In the 1800s and 1900s, the MFN condition was often included in many treaties, especially treaties of Commerce, Navigation and Friendship ${ }^{97}$.

Regarding goods, the MFN refers to the purpose of non-discrimination between similar import goods from different countries. The prohibition of discrimination among like products originated in or destined for different members exists in the WTO as an incentive for reciprocal concessions that should be extended to all the members of the WTO.

By interpreting the MFN clause of the Article 1 of GATT-1994, one can identify that it has economic and political arguments. Considering political issues, it is a political measure entitled to dissolve offensives in international relations helping to promote multilateralism and diminish discriminations, since it advocates for an equal treatment of all WTO members.

On the other hand, as an economic measure, it ensures that trade benefits negotiated between two countries will be extended to others. Yet, the MFN also secures the benefits of bargain during the negotiations between members, and has a multiplying effect since the clause often provides a generalization of liberalizing trade policies ${ }^{98}$.

Moreover, the MFN clause as a nondiscrimination measure plays an important role to minimize distortions of the system. When trade restrictions or trade liberalizations are applied uniformly without taking into account the origin of the goods, it is expected that the economic system of allocation and production of products achieve the maximum effect.

\footnotetext{
${ }^{96}$ Jackson, 2000a, p. 161.

${ }^{97}$ Id., p. 158.

${ }^{98}$ See Koul, 2005, p. 80 and Jackson, 2000a, p. 159.
} 
According to the text of GATT-1994, the MFN treatment concerns the obligation to grant to all the members advantages regarding customs duties, charges on imports and exports, internal taxes, internal regulations affecting the sale, distribution and use of products and any other customs-related matter.

Given the fact that the MFN is understood as a standard of equal treatment between nations, it establishes a very favorable scenario to the multilateralism. Although the MFN clause does not necessarily exist in every multilateral system, policies that favor MFN also favor multilateralism.

The MFN clause can also be found in GATS Agreement (Article II), in what refers to trade in services, and in TRIPS Agreement (Article IV) in aspects related to intellectual property. In Article II: 1 of the GATS there is the prohibition of discrimination between like services and service suppliers from different countries, while in Article IV of TRIPS it is affirmed that any advantage, favour, privilege or immunity granted by a member regarding intellectual property rights to the nationals of any other country shall be accorded immediately and unconditionally to the nationals of all other members.

It is important to note that, according to Peter Van den Bossche, the MFN treatment obligation in the WTO does not concern only advantages granted to other members, but advantages granted to all and any other country, by that including non-WTO member. That means that if a WTO member concedes a trade advantage to a country that is not under the WTO, according to Article 1:1 of GATT the member shall be constrained to grant the same advantage to all WTO members ${ }^{99}$.

The essence of non-discrimination obligations in the WTO is in the fact that like products, or like services, shall be treated equally and without taking into account their origin. Among other cases brought to the DSB, the EC-Bananas III complained about the less favorable treatment that bananas coming from Latin American countries were receiving in comparison with bananas coming from former European colonies - referred to as ACP countries - (Asian, Caribbean and Pacific former colonies) ${ }^{100}$.

In the literature regarding the MFN clauses there is a distinction between conditional and unconditional MFN treatment. Under conditional treatment, when a country

\footnotetext{
${ }^{99}$ Van den Bossche, 2005, p. 312.

${ }^{100}$ WTO DS27, EC-Bananas III.
} 
grants some privilege to another, for example country A grants a privilege to country $\mathrm{C}$ but $\mathrm{A}$ owes a MFN treatment to B, it means that country A must grant B the equivalent privilege. Notwithstanding, this must happen only after country B has given country A some reciprocal privilege. That is not what happens in the WTO.

Actually the WTO Agreements deal with the unconditional MFN clause, that means that country A must grant privileges to country B without receiving any privilege or return from B. It is broadly understood that unconditional MFN clauses can help spread trade liberalization with more efficiency and in a faster way. By granting the same advantages to all the members of the WTO, each country allows equal access to its own market and has the same opportunities to access other countries market as any other member of the Organization.

Although the MFN clause has been widely recognized since GATT 1947 as a fundamental obligation among members of the multilateral trading system, it is accepted that there are many breaches and exceptions to the MFN treatment that allow discriminatory regimes and preferential systems responsible for the big part of all world trade moves that some countries have. Indeed the text of the GATT had foreseen that before, so much so that Article XXIV of its text provides exceptions for customs unions, free trade areas, and interim agreements leading to either, provided that they meet certain conditions.

For example, in the case of the creation of a preferential area, a third country that will not make part of the new block agreement has to have its trade situation respected and not worsened in what relates to the countries that are going to be part of the preferential trade area.

Other exceptions to the application of the MFN clause and especially important to this dissertation are the ones contained in Article IV of the TRIPS Agreement that determines exemptions of the MFN obligation in case of advantage, favor, immunity or privilege deriving from, for example, an international agreement on judicial assistance or law enforcement; granted in accordance with the provisions of the Berne Convention (1971) or the Rome Convention and; deriving from international agreements related to the protection of intellectual property which entered into force prior to the entry into force of the WTO agreement $^{101}$.

${ }^{101}$ Article IV, TRIPS Agreement. 


\subsubsection{National Treatment}

The nucleus of the multilateral trading system is formed by the principles of the MFN treatment and the national treatment. Both principles together - which were put into force by GATT 1947 and confirmed by the WTO System in 1994 - try to ensure the nondiscrimination in international trade. As the principle of MFN, the National Treatment is also contemplated in the most important (and compulsory) WTO agreements: GATT 1994, GATS and TRIPS.

The national treatment obligates each country to grant to the import product no worse treatment than that it granted to its domestic products. After cleared customs and border procedures, all import products have to have the same national treatment as any domestic product regarding regulatory and tax measures. That means that no member shall apply internal taxes or any other internal charges to imported or domestic products in a different way as the one set in paragraph 1 of Article III of GATT ${ }^{102}$. Indeed, the national treatment applies only to internal measures and does not worry about border measures, which are taken care of in other GATT Articles (especially Article XI).

Actually, the national treatment not only refers to products, but may also be applied to other activities such as the intellectual property rights. According to Article 3 of the TRIPS Agreement, it has to be confirmed by the nationals of every WTO member as a treatment no less favorable as each member granted to its own nationals regarding the protection of intellectual property. The national treatment will take into account the exceptions already provided in the Paris Convention of 1967, the Berne Convention of 1971, and the Treaty on Intellectual Property in Respect of Integrated Circuits (Rome Convention).

By way of reference, the GATS agreement mentions national treatment in the body of its text (Article XVII) but the meaning of national treatment related to services presents some restrictions in the literature. Basically it is understood, as Van den Bossche states, that the national treatment related to services is only applicable to the extent that WTO

\footnotetext{
${ }^{102}$ Article III:1 of GATT: "The contracting parties recognize that internal taxes and other internal charges, and laws, regulations and requirements affecting the internal sale, offering for sale, purchase, transportation, distribution or use of products, and internal quantitative regulations requiring the mixture, processing or use of products in specified amounts or proportions, should not be applied to imported or domestic products so as to afford protection to domestic production".
} 
Members have explicitly committed themselves to grant national treatment in respect to specific service sectors ${ }^{103}$.

The intention of Article III of GATT is - besides promoting nondiscrimination in international trade relations - to avoid protectionism of members regarding their domestic products and granting equality of procedures and tax measures to goods and services, either national or international. A good summary is brought by the Report of the WTO Appellate Body concerning this principle since it states that: "The Article III national treatment obligation is a general prohibition on the use of internal taxes and other internal regulatory measures so as to afford protection to domestic production" ${ }^{104}$.

Countries in general and especially the importing ones have an inclination to adopt discriminatory measures to protect the national production. More than taxes application, there are a number of regulations, technical barriers, sanitary measures, among other features, that are known to be used by the countries to distort trade and competition. By the rule of Article III of GATT the multilateral trading system tries to impede the application of protectionist policies aiming to induce fair trade and trade liberalization.

The national treatment is a wide-ranging obligation that can be invoked in many situations regarding goods, services or intellectual property rights. In fact it has been a major complaint in the dispute settlement system since GATT 1947. As Hoekman explains the obligation covers taxes and other policies that have to be administrated in a nondiscriminatory way among like domestic and foreign products, regardless of whether a specific tariff commitment was made ${ }^{105}$.

\subsubsection{Other Principles and exceptions}

Special attention was given to the MFN treatment and the national treatment since they are broadly understood as the cornerstones of the nondiscrimination treatment in the multilateral trading system. Notwithstanding, there are other basic principles as important as the ones above responsible for the outline of the WTO functioning.

\footnotetext{
${ }^{103}$ Van den Bossche, 2005, p. 371.

${ }^{104}$ Report of the Appellate Body Japan- Taxes on Alcoholic Beverages WT/DS8/AB/R, WT/DS10/AB/R, $\mathrm{WT} / \mathrm{DS} 11 / \mathrm{AB} / \mathrm{R}$.
} 
A list of principles followed by the WTO cannot be found in its agreements, but the rules are spread in the legal texts and decisions adopted by the Organization. Hoekman organizes the principles in four other categories besides the aforementioned nondiscrimination principles, three of which will be briefly explained in this section since their clarification is considered important for this dissertation. To finish this first chapter, the exceptions to trade liberalization brought in the legal text of GATT will be mentioned.

\section{- $\quad$ Reciprocity}

The principle of reciprocity has a motivator role in the WTO system, responsible for granting equal privileges between countries. Taking an example from international trade, a country can accept to lower import duties or technical barriers in return for equal or similar concessions from another country.

Reciprocity is a basic principle upon which international trade has been developed for a long time. Regarding the multilateral trading system, since GATT 1947 the negotiations were established on a reciprocity basis so to motivate countries to open their markets and receive equivalent advantages or privileges in return for other countries. Indeed, Hoekman states that the principle of reciprocity reflects the desire of getting something back (a payment) for trade liberalization through a better access to markets and constitutes a manner of limiting the scope of free-riders in liberalization process ${ }^{106}$.

The preamble of the GATT and of the WTO agreement highlight the intention of achieving the objectives of the Organization by reciprocal and mutually advantageous arrangements toward tariff reduction as well as the reduction of other barriers to trade and elimination of discrimination treatment among nations relating to international trade.

Regarding nondiscrimination, it is important to mention that the principle of reciprocity works very closely with the MFN treatment. As aforementioned, the literature divides the MFN treatment into conditional and unconditional. The principle of reciprocity would be closer to the meaning of conditional MFN treatment, when a country grants some advantage or privilege to another expecting to be paid in return.

\footnotetext{
${ }^{105}$ Hoekman, 2002, p. 42.
} 
During the GATT negotiations the participation of developing countries was possible and guided by what was called relative reciprocity, according to which developing countries did not have to grant the same advantages or privileges received from developed countries, especially regarding tariff concessions.

Nevertheless, under the WTO agreements the terms of bargain where altered by a demand of the develop countries that all the negotiated commitments be combined in a singleundertaking, through which the countries had to decide to accept all the multilateral agreements or leave the GATT system. According to Hudec, "this new approach completely restructured the developed-developing country bargain, proposing to pay for all the new developing country concessions simply by agreeing not to destroy the market access they already had"107.

\section{- Transparency}

Transparency means that the rules imposed by countries relating to international trade must be published in government's websites, in a clear and easily understandable way. The enforcement of commitments relating to trade requires access to the regimes that are maintained by members.

The transparency principle is a legal obligation under the WTO embedded in Article X of the GATT and Article III of the GATS. Basically transparency defines that all regulations related to international trade must be published promptly, so as to enable governments and agents of foreign trade to be aware of what is going on in each country in matters of trade. Also, all members are required to respond to requests for information by other members and to notify the WTO of all changes in trade policy ${ }^{108}$.

Among the benefits provided by transparency are, of course, the possibility for members and its citizens to be aware of what is going on with trade practices in their own country and of partners countries and, at the same time, the possibility of learning about the

\footnotetext{
${ }^{106}$ Hoekman, 2002, p. 43.

${ }^{107}$ Hudec, 1987, p. 107.

${ }^{108}$ Hoekman, 2002, p. 44.
} 
WTO and its procedures. By giving transparency to what happens in the Organization, a higher legitimacy and reliability are also addressed to the WTO.

Notwithstanding, it is important to say that there are many complaints about the WTO procedures and practices regarding the dispute settlement system and that is one of the reasons why the Doha negotiating mandate of 2001 recognized the need of improvements and clarifications of the Dispute Settlement Understanding.

\section{- Binding and Enforcement Commitments}

One of the most important achievements of the Uruguay Round was to enforce commitments between multilateral trade players. Agreements and commitments regarding trade have little (or no) value if they cannot be enforced.

Differently from the GATT 1947, the WTO was established as an international treaty under the auspices of the public international law system. From there it is possible to perceive that its rules and agreements have a stronger binding effect than the ones accorded under the scope of the GATT. As previously mentioned in this dissertation, an international treaty produces international effects to its members, in other words, it produces rights and obligations to the subjects that sign the treaty.

In the sphere of multilateral trade system, the tariff commitments and the commitments on accession made by the WTO members are enumerated in lists of concessions (schedule of concessions). As Hoekman explains, those schedules establish ceiling bindings, which mean that the member concerned is not allowed to raise tariffs above bound levels without previously negotiating compensations with the main supplier of the product concerned. Those compensations will be extended to all WTO members as a natural consequence of the process once all members are bound by the MFN treatment rule.

Moreover, Hoekman emphasizes that "once tariff commitments are bound, it is important that there be no resort to other, nontariff, measures that have the effect of nullifying or impairing the value of the tariff concession" ${ }^{109}$.

${ }^{109}$ Id., p. 43. 
Regarding the crux of this research endeavour, namely, the dispute settlement system, it has been refined with the implementation of legal remedies to strengthen the mandatory rules of the multilateral trading system with the creation of the WTO. Actually the Uruguay Round negotiated and adopted a number of reforms intended to reinforce the effect of the WTO decisions and rulings. Indeed, Hudec states that "the primary remedy set forth in the WTO Dispute Settlement Understanding (DSU) is still the legally binding 'recommendation' ordering the defendant to bring its conduct into compliance"110.

\section{- Exceptions}

Trade liberalization is the law that guides the GATT/WTO system. The general rules of the system are brought to the multilateral trading system with special attention to the principles of MFN, national treatment and transparency, apart from the prohibition of quantitative restrictions ${ }^{111}$.

Nevertheless there are exceptions to it that according to Barral can be found distributed in GATT's text: (a) permanent exceptions; (b) contingency exceptions and; (c) exceptions in favor of developing countries ${ }^{12}$ :

\footnotetext{
- $\quad$ Permanent exceptions: Article XX of the GATT 1994 states general exceptions emphasizing that nothing in the Trade Agreement on Goods shall be constructed to prevent the adoption or enforcement of measures regarding to public moral and to human, plan or animal's health; trade in gold and silver, the protection of patents, trademarks and copyrights, artistic and historical treasures; exhaustible natural resources and guarantees of essential goods. Barral also includes among the permanent

${ }^{110}$ Hudec, 1987, p. 103.

111 The prevision regarding quantitative restrictions was based on the prevision of GATT 1947 that once members have binding tariff limits, they would look for other mechanisms to protect domestic industries. Nowadays the prevision regarding general elimination of quantitative restrictions is expressed in Article XI of GATT 1994.

${ }^{112}$ Barral, 2007, p. 71-72. See also Jackson, 2000a, p. 54-57.
} 
exceptions mentioning the waivers (Article IX, GATT), national security (Article XXI, GATT) and the renegotiation of concessions;

Contingencial exceptions: give members the possibility of restricting the amount or value of imported goods in order to safeguard its external financial position and its balance of payments (Articles XII to XV, GATT) and; the protection to the domestic industry in cases that an specific industry in rising and it is necessary to give it a temporary protection;

Exceptions to developing countries: dealing with trade and development, part IV of GATT 1994 points out a number of possibilities that are available to developing countries in order to promote growth through trade referred to as 'special and differential treatment', among which are the possibility of nonreciprocity and the enabling clause ${ }^{113}$.

\subsection{Concluding Remarks}

The present chapter aimed at situating the dissertation in the area of international law to where it belongs. With the first section the concepts and elements of international law and economic relations that influence the body and the final result of research were presented to prepare the ground for the discussions that follow.

Unquestionably, the GATT/WTO system is the main responsible factor for the enormous growth and liberalization that international trade has experienced since 1947 through rounds of negotiations and binding tariff commitments agreed in a nondiscrimination mood.

\footnotetext{
${ }^{113}$ According to the WTO, the Enabling Clause is the Organization legal basis for the Generalized System of Preferences (GSP). Under the GSP, developed countries offer non-reciprocal preferential treatment (such as zero or low duties on imports) to products originating in developing countries. The Enabling Clause is also the legal basis for regional arrangements among developing countries and for the Global System of Trade Preferences (GSTP). Published online at:

$<$ http://www.wto.org/english/tratop_e/devel_e/dev_special_differential_provisions_e.htm>. Accessed in: Jan. 2011.
} 
The emergence of the WTO and its dispute settlement system (which is going to be explained in more detail in the next chapter) brought predictability and legal security in multilateral trade relations making the WTO a unique Organization. Actually, it is possible to state that the dispute settlement mechanism is an essential pillar for the effectiveness of the agreements reached by WTO members. 


\section{WTO DISPUTE SETTLEMENT AND COMPLIANCE: strengths, weaknesses and cross-retaliation}

This chapter is dedicated to the explanation of the dispute settlement system, its legal remedies and the mechanism of cross-retaliation. The WTO system for the resolution of trade disputes is the result of over four decades of experience under the GATT 1947.

Unlike the GATT 1947, which has a diplomatic approach, the WTO system is clearly rule-oriented. However, the understanding of the WTO dispute settlement system is only possible in the light of the experience with disputes resolution during the GATT period, before the establishment of the WTO.

Argueably, the WTO dispute settlement system is one of the most important achievements of the Uruguay round. In 1995, the system added the security and predictability that was missing in the multilateral trade relations.

As the dispute settlement is one of the core topics of the present research, it is important and necessary to clarify its jurisdiction, functions and, above all, the issues regarding the implementation of DSB decisions.

WTO remedies are largely discussed among professionals, academics and WTO staff. Those remedies can be defended as great achievements of the organization as they, somehow, try to punish the violating member while compensating the victim. Despite these achievements, the remedies enforced by the WTO show their weaknesses when confronted with the real power of strong economies that make part of the multilateral trade system.

The present chapter is dedicated to explore selected provisions of the DSU that are considered to be crucial for the reflection proposed in this dissertation. The aim is to promote an overview of the elements necessary to compose a further reflection on the topic; the analysis of details of the overall dispute settlement system is outside the scope of this work and thus will not be explored.

The last section in this chapter is dedicated to the cross-retaliation mechanism. There is yet no explicit provision for that mechanism, but only suggestions in the body of the DSU - when traditional retaliation is considered neither practical nor effective. The analysis of the cross-retaliation is of extreme importance for progression to the next chapter, as the 
cross-retaliation mechanism seems to have become popular weapon in the system for the use of the developing country members.

\subsection{Jurisdiction of WTO Dispute Settlement Body}

As mentioned before, the WTO dispute settlement system was designed in accordance with the pre-existing GATT regime. This is so true that despite being a ruleoriented system, the consultations and negotiations - as they were made during GATT - are still a fundamental step before proceeding to the establishment of a panel at the DSB ${ }^{114}$.

Before proceeding to an explanation of the WTO dispute settlement mechanism, it is necessary to identify what is under the scope of application of the system. The competence of the system is highlighted in Article 1 of the DSU. According to the first paragraph, the DSU shall be applied to any consultations or disputes related to the agreements listed in Appendix $1^{115}$.

According to Article 1.2 of the DSU, the rules of the Understanding shall be applied with the observance of specific rules present in any of the covered agreements. As way of reference, from the same paragraph it is possible to extract the information that the basic objective of the DSU is to avoid conflict ${ }^{116}$. This is important to notice because the DSU was not meant to be a mechanism of sanction, but instead a mechanism to avoid commercial conflicts so as to bring back the balance of trade relations among countries whenever an inconsistency exists.

Indeed, several provisions of the DSU highlight the aim of the system to withdraw any inconsistency with WTO agreements as well as to secure a positive solution to a dispute. Moreover, from the interpretation of the understanding, there is a clear preference to a

\footnotetext{
${ }^{114}$ The consultation process is already in the text of Article XXII, GATT 1947: "Each contracting party shall accord sympathetic considerations to, and shall afford adequate opportunity for consultation regarding, such representations as may be made by another contracting party with respect to any matter affecting the operation of this agreement".

115 Article 1.1, DSU. The agreements listed in Appendix 1 are: (i) Agreement Establishing the WTO; (ii) Multilateral Trade Agreements and. (iii) Plurilateral Trade Agreements. Regarding the Plurilateral Trade Agreements, according to the text of Appendix 1, its application "shall be subject to the adoption of a decision by the parties to each agreement setting out the terms for the application of the Understanding to the individual agreement". Published online at: <http://www.wto.org/english/docs_e/legal_e/28-dsu_e.htm\#appendix1>. Accessed in Feb. 2011.

${ }^{116}$ Article 1.2, DSU.
} 
solution achieved between the parties, which are both positive and consistent with WTO agreements $^{117}$.

The general provisions of the DSU are set in the Article 3 of the understanding. In the first paragraph it establishes the adherence to the principles of Articles XXII and XXIII of the 1947 GATT. Then, there is the recognition that the dispute settlement is the cornerstone of the multilateral trade system, deploying security and predictability to members' trade relations ${ }^{118}$.

Yet pursuant Article 3, the understanding serves not only to preserve the rights and obligations of members, but also to clarify the existing provisions. The interpretation of WTO provisions shall be done in accordance with customary rules of interpretation of public international law, in a clear reference to the Vienna Convention on the Law of Treaties.

It is remarkable that the DSU itself makes a reference to the principles of public international law to guide panels and the Appellate Body ${ }^{119}$. That is coherent and in line with what was previously defended in this dissertation. The WTO is an international organization, established under a public international law treaty. Therefore, the WTO is part of the Public International Law (hereon PIL) and finds its roots in it.

Moreover, as an international organization, the WTO Secretariat should observe general principles of international public law and State responsibility, as should WTO Members. As it is, the WTO Law exceeds the sphere of PIL and establishes its own remedies and state responsibility for the breaches of its rules. This is permitted by PIL and, indeed, as defended by Barbara Oliveira, WTO Law “develops secondary rules which deviate from, and further refine and adapt, general international law" ${ }^{120}$.

As pointed out by Luiz Olavo Baptista, the WTO dispute settlement system is a singular experience for International Law. The system established a compulsory jurisdiction to trade related matters and the possibility of applying sanctions to the members that insist in keeping an inconsistent measure with WTO rulings ${ }^{121}$.

\footnotetext{
${ }^{117}$ See also Jackson, 2002, p. 258.

${ }^{118}$ Article 3, DSU.

${ }^{119}$ See Matsushita; Mavroids; Schoenbaum, 2003, p. 23.

${ }^{120}$ Oliveira, 2006, p. 2.

${ }^{121}$ See Baptista, 2007, p. 16.
} 
Despite the possible problems that could arise by the implementation of a legalistic system to replace the diplomatic character of GATT; a system that places more emphasis on adjudication than on negotiation has its advantages. First, it gives less space for the use of political and economic power in cases involving countries with a considerable market size difference. In this sense, a rule-oriented system instead of a negotiation orientated one is intended to be either fairer or more predictable ${ }^{122}$.

Second, a legalistic system deploys a sense of security for relations, trade relations in this case. With clear rules for discipline relations, the WTO members have a map of the behavior they should adopt in their internal and external actions regarding trade. At the same time, to the members is given the possibility to complain about inconsistencies with WTO rules by other members before a legal body.

Third, a strong argument in favor of a legalistic and adjudicative system is related to compliance with WTO rules. There is an inclination to believe that a more legalistic system results in a higher rate of compliance with WTO rulings and decisions. Indeed, as affirmed by Davey, an adjudicative system: (i) discourages rule violators because all the members have the knowledge that in violating WTO rules they will be called to account and; (ii) from the experience it can be concluded that panel and Appellate Body reports are normally implemented $^{123}$. In fact, currently there is a rate of around $83 \%$ implementation of WTO recommendations and decisions ${ }^{124}$.

The issue of the jurisdiction of the DSB is limited to the claims under the WTO covered agreements. That means that claims of violation of rules of international law that do not refer to WTO agreements should not be appreciated by the DSB. Notwithstanding, there is no connection between the jurisdictional limitation and the law applicable to cases brought

\footnotetext{
${ }^{122}$ Considering the possible problems of a legalistic system, William J. Davey mentions that critics claimed that it would promote conflict and contentiousness in the organization and that the wrong cases would be broken to the organization, undermining the GATT system. Davey, 2002, p. 247-251. Also, Robert Hudec indicates the possibility of wrong cases being presented before the DSB, diminishing the prestige of the GATT and its rules. Hudec, 1980. p. 159.

${ }^{123}$ Davey, 2003, p. 5.

${ }^{124}$ Davey, 2005, p. 12. The general high rate of compliance with WTO recommendations does not interfere in the importance of the presentations for three basic reasons: (1) in not guaranteeing $100 \%$ of implementation of its decisions, the WTO dispute settlement system has problems that must be reviewed; (ii) every decision not implemented might cause considerable economic and social trouble to members involved in the disputes - and perhaps to the multilateral trade system as a whole and; (iii) the rate of $83 \%$ is general and does not reflect the rate of compliance/implementation when the claimant is a much smaller economy than the defendant.
} 
before the DSB. In the absence of a restriction, the panels as well as the Appellate Body have the freedom to recourse to various sources of international law to decide a dispute ${ }^{125}$.

Joost Pauwelyn explains that panels also have incidental jurisdiction, with four basic objectives: (i) interpret the demand of the parties so as to isolate the real issue related to the case and identify the core of the claim; (ii) the principle of la competence de la competence, which refers to the determination of whether one has jurisdiction to decide a matter; (iii) decide whether or not one should refrain from exercising substantive jurisdiction that has been validly established and; (iv) incident jurisdiction to decide every matter related to the exercise of substantive jurisdiction and inherent to the judicial function ${ }^{126}$.

Finally, the WTO dispute settlement system does not have an advisory jurisdiction, but only a contentious one ${ }^{127}$.

\subsection{Dispute Settlement Procedures}

The WTO dispute settlement mechanism is one of the most important instruments of the multilateral trade system, responsible for the effectiveness that is attributed to the Organization.

Beyond the set of rules that aim to provide predictability and legal security concerning the organization of panel's procedures, the WTO dispute settlement system presents the peculiar characteristic of applying sanctions to the breaches of its rulings. Although the DSU does not mention the word "sanction", the possibility of compensation and retaliation implies the notion of sanction to deal with inconsistencies.

In fact the possibility of applying sanctions is quite limited in other international organizations because of restrictions imposed by the states themselves, attached to the concept of Westphalian sovereignty. Indeed, as Barral and Prazeres argue, that limitation of other international organizations ultimately leads to limited public international law ${ }^{128}$.

\footnotetext{
${ }^{125}$ See Bartels, 2001, p. 503; Pauwelyn, 2003, p. 456-471.

${ }^{126}$ Pauwelyn, 2003, p. 448.

${ }^{127}$ Van den Bossche, 2005, p. 190.

${ }^{128}$ Barral; Prazeres, 2002, p. 28.
} 
Yet the WTO dispute settlement mechanism is responsible for creating a space for negotiation within the Organization for the countries involved in disputes. Also, it contributes to the reduction of arbitrary market distortions as well as the reduction of unilateral economic measures by members.

Basically the integrated dispute settlement system consists of a General Council and a Technical Council, besides the panels constituted by arbitrators and a permanent Appellate Body. The WTO dispute settlement is a unified system with a broader jurisdiction and less scope for rule shopping and forum shopping ${ }^{129}$.

The procedures to access the system are explained in detail in the following sections.

\subsubsection{Consultations}

To activate the dispute settlement system of WTO the first mandatory step is to forward a formal request for consultation to the respondent State and notify the WTO General Council.

The consultation is understood as an opportunity to consult members about measures affecting the operation of any of the covered agreements. According to Article 4.3, if a request for consultation is made, the member to which the request is made shall reply to the request within 10 days of its receipt, if not agreed otherwise. With a view to reaching a mutually satisfactory solution, the member shall enter into consultations in good faith with no more than 30 days of the date of the receipt of the request ${ }^{130}$.

Notwithstanding, if the member does not respond to the request of consultations within 10 days of the receipt of the request, or does not enter into consultations within a period of no more than 30 days - or a different period mutually agreed -, then the member that requested consultations may proceed to the request for the establishment of a panel ${ }^{131}$.

During the consultations the parties involved try to learn more about the facts, the possible inconsistencies and the legal arguments of the member that is requested. The hope of

\footnotetext{
${ }^{129}$ Petersmann, 1997, p. 178.

${ }^{130}$ Article 4.3, DSU.

${ }^{131}$ Id.
} 
the WTO is that the parties will reach a solution without having to invoke the formal process of dispute settlement. The DSU does not rule the manner parties should conduct consultation, which is up to the parties ${ }^{132}$.

The member that requests a consultation shall include in it all relevant claims. That is so true that the Appellate Body noted in the case India - Patents (US) that "all parties engaged in dispute settlement under the DSU must be fully forthcoming from the very beginning both as to the claims involved in a dispute as to the facts relating to those claims" $" 133$.

The consultations can be individual processes or joint processes. Individual consultation refers to consultations between two members, when one member requests consultations to another member. On the other hand, joint consultations are the consultations held by several members (individually or in groups) and another member. Still, there is the situation called joined consultations, which refers to cases in which members want to join a consultation process already in course ${ }^{134}$.

The whole procedure of consultations shall be confidential, with the participation restricted to the members involved and the members that are allowed to join. If a mutual agreed solution is not achieved, all the relevant material collected during the consultations can be used as information to the panel.

In this regard, the confidentiality required by Article 4.6 of the DSU establishes that the consulting parties not disclosure any information obtained in consultations to any parties not involved in those consultations. The panel of the case Korea - Taxes on Alcoholic Beverages confirmed that information and stated that the essence of consultations is to enable the parties to gather correct and relevant information, for purposes of assisting members in achieving a desirable mutually agreed solution, or, if failing in doing so, to assist members in presenting accurate information to the panel ${ }^{135}$.

Moreover, one consideration that deserves to be given attention to is the special regulations for developing countries. To illustrate, in the context of consultations, Article 4.10

\footnotetext{
${ }^{132}$ See Davey; Jackson; Sykes, 2002, p. 259.

133 Appellate Body Report, India - Patent Protection for Pharmaceutical and Agricultural Chemical Products (US) - WT/DS50/AB/R (16 January 1998) para. 94.

${ }^{134}$ See Li; Mercurio; Yang, 2005, p. 44.

${ }^{135}$ Panel Report, Korea - Taxes on Alcoholic Beverages (EC) - WT/DS75/R (17 September 1998) para. 10.23.
} 
of the DSU demands that special attention shall be given to the particular problems of the developing countries ${ }^{136}$. Also, Article 12.10 states that in consultations involving a measure taken by a developing country, the parties may agree in extending periods established in paragraphs 7 and 8 of Article $4^{137}$.

Beyond the consultation, the DSU states procedures that are undertaken voluntarily if the parties in the dispute so agree. Those procedures are in Article 5 and concern good offices, conciliation and mediation.

These three procedures are referred to by the DSU as settlement techniques that are confidential and may begin or be terminated at any time. Basically, a good officer works as a channel of communication between parties. The conciliator usually makes a written proposal for the settlement of the dispute based on his or her own investigation. A mediator is a more active participant and brings the parties together making suggestions for resolution of the dispute ${ }^{138}$.

\subsubsection{Panels}

If the parties cannot reach a mutual agreed solution during the consultations, the Article 6 of the DSU rules a creation of an ad hoc three-person (exceptionally five) panel of judges. The complaining party is entitled to the establishment of a panel.

According to Article 6.1, a panel shall be established at the second meeting at the DSB following the meeting at which the request for a panel first appears as an item on the DSB's agenda $^{139}$.

At the first meeting at which the request for a panel is made, the respondent can deny the request, forcing another meeting with a new request at the next DSB meeting. From

\footnotetext{
${ }^{136}$ Article 4.10, DSU.

${ }^{137}$ Article 12.10, DSU.

${ }^{138}$ See Matsushita; Mavroids; Schoenbaum, 2003, p. 27.

139 Article 6.1, DSU states that: "If the complaining party so requests, a panel shall be established at the latest DSB meeting following that at which the request first appears as an item on the DSB's agenda, unless at that meeting the DSB decides by consensus not to establish a panel".
} 
the practice it is noted that the respondent generally blocks the first request for a panel with the intention of delaying the process ${ }^{140}$.

It is important to highlight that a panel must be established at the next DSB meeting, unless it is decided by consensus to deny its establishment. The negative consensus is an important innovation in the multilateral dispute settlement system implemented by the WTO, in 1995.

For the purpose of establishing a panel, Article 6.2 states basically four conditions: (i) the request has to be written; (ii) indications whether consultations were held may be present; (iii) there may be identifications of measures subject to the dispute and; (iv) the complainant has to deliver a summary of the legal basis for the claim ${ }^{141}$.

Article 7 of the DSU determines that, unless agreed differently by the parties within 20 days from the establishment of the panel, panels shall refer to and follow what the Understanding calls Terms of Reference. Terms of reference fulfill a due process objective of WTO panels. They provide the necessary information for the parties involved (including third parties) to be aware of the claims and, at the same time, allow them to respond to the case ${ }^{142}$.

The judges of the panel are chosen among well-qualified governmental or nongovernmental individuals from the lists maintained by the WTO Secretariat. Also, the members of the panel shall be selected in a way to ensure the independence of the members with diverse background and broad experience ${ }^{143}$.

As can be found in other legal texts of the WTO, there is in the DSU some special notes regarding developing countries. In what concerns the panels, Article 8.10 allows, in a dispute involving a developed member and a developing country member, that at least one panelist shall be from a developing country member, if so requested ${ }^{144}$.

\footnotetext{
${ }^{140}$ See Li; Mercurio; Yang, 2005, p. 57.

${ }^{141}$ Article 6.2, DSU. Notice that consultations are not mandatory in every case. That is why Article 6.2 asks the members to indicate whether or not consultations were held. For detailed information please see Li; Mercurio; Yang, 2005, p. 59-60.

${ }^{142}$ See Li; Mercurio; Yang, 2005, p. 73-74.

${ }^{143}$ Article 8.1 and 8.2, DSU.

${ }^{144}$ Article 12.10 (already mentioned) and 12.11 of the DSU also has especial provisions for developing countries. Article 12.11 states that: "Where one or more parties is a developing country Member, the panel's report shall explicitly indicate the form in which account has been taken of relevant provisions on differential and morefavorable treatment for developing country Members that form part of the covered agreements which have been raised by the developing country Member in the course of the dispute settlement procedures".
} 
The panels are present in the Dispute Settlement system to assist the DSB in complying with its responsibilities under the Understanding and the covered agreements. That is why panels shall make objective assessment of the facts as well as an objective assessment of the matter before it. In assisting the DSB, panels will make recommendations and give the rulings provided for in the covered agreements ${ }^{145}$.

One last subject that is important to be pointed out in this research refers to the adoption of panel reports. With the objective of providing sufficient time for members to consider the content of panel reports, the DSU gives 20 days from the day of circulation to the members to consider the adoption of panel report ${ }^{146}$.

According to Article 16 of the DSU, a panel report shall be adopted at a DSB meeting after 60 days of the day of circulation unless the DSB decides by consensus not to adopt the report or a party of the dispute notifies the DSB its intention to appeal.

\subsubsection{Appellate Body}

The DSU created another innovation in 1994 - the Appellate Body -, which is the court of second instance of the WTO. Unlike the procedures for consultations, conciliation, good offices, mediation and arbitration panels, the possibility of an appellate review is something unique regarding the settlement of international trade disputes ${ }^{147}$. The DSU provides the possibility of either or both parties to appeal the panel decision.

The Appellate Body is composed of seven members appointed for a four-year term. The members cannot be affiliated to any government and they work in groups of three members. The Appellate Body has the power to uphold, modify or reverse the legal interpretations adopted by the panel ${ }^{148}$.

Also, the Appellate Body is authorized to draw upon its own procedures for the operation of the Body, in consultation with the Chairman of the DSB and the Director-

\footnotetext{
145 Article 11, DSU.

${ }^{146}$ Article 16, DSU.

${ }^{147}$ See Petersmann, 1997, p. 187.

${ }^{148}$ Article 17.13, DSU.
} 
General. The procedures of the Appellate Body are called "Working Procedures for Appellate Review" and are available at the WTO website ${ }^{149}$.

The review of the Appellate Body is limited to issues of law and legal interpretation adopted by the panel report. Notwithstanding, because of the power given to the Appellate Body in Article 17.13, the review of panel decisions are being broadened.

According to Article 17.5, the proceedings shall not exceed 60 days after the party notifies its decision to appeal before the Appellate Body report. The opinion of the Appellate Body is final and, as with what happens with panel's report, it shall be accepted within 30 days following the circulation, or rejected by the DSB on the basis of negative consensus ${ }^{150}$.

As pointed out by Petersmann, the strictly legal function of the Appellate Body was understood as a rule-oriented substitute for the political practice of GATT system. The panel reports during the GATT, especially during the Uruguay Round negotiations, were being increasingly abused ${ }^{151}$.

Throughout the dissertation more details are going to be pointed out regarding the dispute settlement and Appellate Body procedures as the examination of WTO selected cases is developed in chapter 3 .

Following the present section, the implementation phase deserves careful attention. It is the moment when members confront their biggest difficulties. The implementation of decisions adopted by the DSB by the Members that are violating WTO rulings brings up issues related to the compliance and enforcement of decisions under the WTO system.

\subsection{Implementation}

The implementation phase of the decision is currently one of the most sensible subjects regarding the Dispute Settlement system. In fact, it is the most interesting subject of this chapter as it is closely connected to the discussion about enforcement and compliance at the WTO.

\footnotetext{
${ }^{149}$ WTO website: $<$ http://www.wto.org/english/tratop_e/dispu_e/ab_procedures_e.htm>.

${ }^{150}$ See Schefer, 2010, p. 136.
} 
The problem involves not only the implementation difficulty itself in what concerns the claimed State, but also the probable non-accountability of the loser in order to enforce compliance.

Next this section will deal with the implementation of recommendations and rulings of the $\mathrm{DSB}^{152}$. Here it is considered, on the one hand, the ultimate goal of the DSB of withdrawing the inconsistency in the system and re-balance trade relations among members, and on the other hand the case of noncompliance with the decision adopted. Also, this section is going to encompass the available resources for the winner to induce the withdrawal of the inconsistent measure or to request a proportional compensation.

It is true that the prompt implementation of the recommendations and rulings of the DSB is responsible - to a large extend - for the credibility of the WTO dispute settlement mechanism. That is the main reason why careful attention to what happens during the implementation period is paid.

It is convenient to reinforce that the main objective of the implementation phase of the decision of the DSB is to induce the State to comply with the decision taken by making its domestic law consistent with the obligations assumed under the WTO. According to the text of the DSU, the decision of the DSB has no punitive or reparative character.

As aforementioned, once adopted the report of the panel and/or the Appellate Body, it gives start to the period of thirty days in which the responding member has to decide on its implementation intentions. This information shall be disclosed at the meeting of the DSB, where the member shall also indicate the difficulties it may have in implementing the decision in its national environment ${ }^{153}$.

Also within this period of thirty days, the State may ask what is known as a reasonable period of time to comply with the decision. Considering the reasons of the responding member, the DSB may decide whether it is impracticable for the member to comply immediately and the reasonable period of time may be considered.

\footnotetext{
${ }^{151}$ See Petersmann, 1997, p. 186.

${ }^{152}$ Although the term recommendation may suggest that there is discretion to the party as to whether to follow a recommendation that is not the case according to the DSU. Recommendations and rulings are how the decisions of the DSB are referred to in the text of the DSU, and they are binding. This will be further discussed later on in this chapter.

${ }^{153}$ The responding Member that cannot immediately withdraw the measure declared inconsistent with the WTO agreements has the burden of proving why it becomes impossible to comply immediately with the DSB decision.
} 
Pursuant Article 21.3 of the DSU, the reasonable period of time can be determined in three different ways: (i) a proposal from the affected part; (ii) by agreement between the parties within forty-five days - which can also be a possible extension by mutual agreement or (iii) by binding arbitration concluded within ninety days of adoption of the report ${ }^{154}$. The recourse to arbitration procedures (Article 21.3 (c)) normally takes place when the parties cannot achieve an agreement concerning the reasonable period of time.

After the determination about whether the report will be implemented immediately or if it is necessary to establish a new deadline, the affected WTO Member normally starts the procedures for implementation bringing the measure into consistency within the covered agreements.

Aiming to supervise the improvements made for the implementation of the DSB decision, Article 21.6 determines that the DSB shall keep under surveillance the implementation of adopted recommendations or rulings. Therefore, any WTO Member may raise the issue of implementation from six months of the establishment of the reasonable period of time ${ }^{155}$.

Hereupon, regarding the enforcement of decisions, the procedure of the DSU then foresees two stages, which work in the following order: (i) it is expected the voluntary implementation of the decision, to which a reasonable period of time may be provided, if not possible immediate implementation, (ii) if there is no voluntary implementation of the decision of the panel or the Appellate Body report, there is the possibility of compensation or suspension of concessions with the State that refuses to comply with the decision, upon authorization of $\mathrm{DSB}^{156}$.

\footnotetext{
${ }^{154}$ See Article 23, DSU. The article further adds that this period should not exceed fifteen months after the adoption of the report issued by the OSC. This term is indicative and the same article notes that it can be extended or shortened, depending on the circumstances of the case. See Perez Gabilondo, 2004, p. 223. JeanMarc Sorel (2004, p. 114) adds that while there is a determination that there should be a final decision within ninety days following the adoption of the report, the parties may agree to an extension of this period.

155 Article 21.6, of the DSU: "The DSB shall keep under surveillance the implementation of adopted recommendations or rulings. The issue of implementation of the recommendations or rulings may be raised at the DSB by any Member at any time following their adoption. Unless the DSB decides otherwise, the issue of implementation of the recommendations or rulings shall be placed on the agenda of the DSB meeting after six months following the date of establishment of the reasonable period of time pursuant to paragraph 3 and shall remain on the DSB's agenda until the issue is resolved. At least 10 days prior to each such DSB meeting, the Member concerned shall provide the DSB with a status report in writing of its progress in the implementation of the recommendations or rulings".

156 See Article 22.1, DSU: "1. Compensation and the suspension of concessions or other obligations are temporary measures available in the event that the recommendations and rulings are not implemented within a reasonable period of time. However, neither compensation nor the suspension of concessions or other
} 
Once the reasonable period of time expires, and if the measure has not been brought into consistency, technically speaking the generation of a quantification of the damage caused begins, which may give rise to a retaliation process.

However, before entering into a retaliation procedure the DSB shall verify whether the actions taken by the member that lost the dispute have not reached a satisfactory level to remove the inconsistency from the system. Therefore, pursuant Article 21.5, where there is a disagreement regarding the consistency with a covered agreement the dispute shall be decided through recourse to the dispute settlement procedures of that Article ${ }^{157}$.

It is valid to address the confusion that arises from the reading of Article 21.5 combined with Article 22.2 of the DSU. While Article 21.5 provides for an expedited compliance procedure, Article 22.2 provides that the winning party may request authorization from the DSB to retaliate by suspension trade concessions within twenty days of the expiry of the reasonable period of time ${ }^{158}$.

In any moment Article 22.2 mentions the procedure pursuant Article 21.5. Therefore, although the confusion may be questioned and while the text of the DSU is not modified in the direction of aligning the concepts and references of the two Articles, the current practice of the WTO is that arbitration under Article 22.2 will take place simultaneously with the proceeding for compliance or only after the compliance proceeding under Article 21.5 is finished ${ }^{159}$.

Before carrying on with the discussion of retaliating measures, as the present research gives especial attention to the treatment given to developing countries under the DSU, it is suitable to address two paragraphs of article 21.

obligations is preferred to full implementation of a recommendation to bring a measure into conformity with the covered agreements. Compensation is voluntary and, if granted, shall be consistent with the covered agreements". This subject is going to be discussed in the next section of the present chapter.

${ }^{157}$ Article 21.5 of the DSU states that: "Where there is disagreement as to the existence or consistency with a covered agreement of measures taken to comply with the recommendations and rulings such dispute shall be decided through recourse to these dispute settlement procedures, including wherever possible resort to the original panel. The panel shall circulate its report within 90 days after the date of referral of the matter to it. When the panel considers that it cannot provide its report within this time frame, it shall inform the DSB in writing of the reasons for the delay together with an estimate of the period within which it will submit its report".

${ }^{158}$ See Matsushita; Mavroids; Schoenbaum, 2003, p. 31.

159 The bibliography calls it sequencing problem. Currently it has become customary to the parties to reach an agreement of procedures under Articles 21 and 22. There are cases in which the parties start the proceedings simultaneously and later, if that is the case, suspend the retaliation procedures under Article 22. For more detailed information, see UNCTAD, 2003, p. 22-23 and; Matsushita; Mavroids; Schoenbaum, 2003, p. 32. 
First, according to Article 21.7, the DSB shall consider the condition of the developing country and take into consideration further actions that may be applicable to the circumstances. In the same sense, the next paragraph understands that if the case is brought by a developing country member, "the DSB shall take into account not only the trade coverage of measures complained of, but also their impact on the economy of developing country Members concerned"160.

\subsubsection{WTO Remedies: Compensation Measures and Suspension of Concessions}

\section{- Compensation Measures}

If the responding Member does not bring its inconsistent measures into conformity with WTO agreements within areas on a reasonable period of time, the prevailing Member has basically two options, namely: the Member can seek compensation for the damages caused to it or ask for an authorization of the DSB to suspend trade concessions or other WTO obligations regarding the respondent.

Compensation measures and suspension of concessions (also called countermeasures), under Article 22:1 of the DSU, are measures available as a temporary option in the case of noncompliance with the recommendations and rulings of the DSB within a reasonable period of time.

As highlighted by the DSU, neither compensation or suspension of concessions nor other obligations are the best alternatives. It is always preferred that the member fully implements DSB recommendations and rulings in order to bring its measures into compliance. Also, it is important to emphasize that the restriction of trade through countermeasures shall be the last resort provided by the DSU, and it is subject to DSB authorization ${ }^{161}$.

Even though they are not the best option, compensation measures can be seen as a favorable instrument for the parties to achieve a temporary consensus until the full

\footnotetext{
${ }^{160}$ Article 21.8, DSU.

${ }^{161}$ See Article 3.7 and Article 22.1, DSU.
} 
implementation of the recommendations of the DSB. Of course, the ways of compensation have to be consistent with the commitments agreed under WTO.

As compensation measures have to be in accordance with the covered agreements, from time to time there are concerns regarding the Most Favored Nation principle - Article I, GATT 1947 -, and the compensation granted to a member. As this is one of the basic nondiscrimination principles of the Organization, it can be argued (and it was) that compensation should not be discriminatory and should benefit only the complaining member ${ }^{162}$.

Notwithstanding, it is understood that although a compensation measure is normally going to establish a temporary more favorable treatment to a member, that does not leave the door open to other members to require the same treatment under the principle of Most Favored Nation. Indeed, Pérez Gabilondo explains that where countermeasures are concerned, a more flexible treatment regarding the Most Favorable Nation shall be applied. The author argues that the compensation is a trade alternative between complainant and respondent in an attempt to avoid retaliation ${ }^{163}$.

If it is not possible to negotiate and agree on compensation between members in twenty days after the day of expiry of the reasonable period of time, the opportunity is given to the complainant to ask the DSB for authorization to retaliate and therefore, to apply countermeasures.

\section{- Suspension of Concessions}

Differently from bilateral negotiations in which members have freedom to achieve a consensus without the interference of the WTO during consultations, the countermeasures have to be approved by the DSB before they are applied. Bilateral negotiations are not permitted and it is mandatory that the Member obtains permission from the Organization to

\footnotetext{
162 In a determined occasion, the Appellate Body recognized in the case European Communities - Poultry that there was "nothing in Article XXVIII to suggest that compensation negotiated within its framework may be exempt from compliance with the non-discrimination principle inscribed in Articles I and XIII of the GATT 1994”. See Appellate Body Report European Communities - Measures Affecting Importation of Certain Poultry Products (WT/DS/ABR, adopted 23 July 1998, para. 100).

${ }^{163}$ See Pérez Gabilondo, 2004, p. 234.
} 
retaliate. Then, after approved by the DSB, the complainant can apply the countermeasures unilaterally without the permission of the respondent.

The countermeasures are normally translated into suspension of trade concessions $^{164}$. Also, they are commonly referred to as retaliation. As Schefer explains, it basically refers to discriminatory subjection of the defendant member to worsening trading conditions offered by the complainant ${ }^{165}$.

Thus, generally countermeasures correspond to the withdrawal of tariff advantages negotiated under the WTO. Therefore the countermeasures are the suspension of tariff concessions advantages applicable to the products from the territory of the respondent, but they can also mean disadvantages in reduced market share opportunities or other nontariff restrictions on liberalized trade.

When the WTO refers to retaliation it is implicit that the two main goals of the countermeasures are to induce the respondent member to comply with the decision adopted by the DSB and, to reestablish the balance regarding the reciprocal concessions related to the dispute $^{166}$.

As the WTO does not interpret countermeasures as sanctions, these measures shall be equivalent to the level of nullification or impairment in discussion ${ }^{167}$. That means that there is no room for punitive damages under the WTO, and the retaliation may occur to the extent that it imposes costs to the respondent equal to the would-be costs of compliance. Furthermore, the equivalence mentioned by Article 22.4 does not allow room for proportionate damages, as equivalence is defined from the level of nullification or impairment $^{168}$.

Article 22.3 of the DSU gives a map of how the members shall proceed with the retaliation. According to the principles of that Article, the complaining member should first seek to suspend concessions or other obligations with respect to the same sector in which the violation was found.

\footnotetext{
${ }^{164}$ Article 22.2, DSU.

165 Shefer, 2010, p. 147.

${ }^{166}$ See Barral, 2004, p. 43; Jackson, 2000b and; Hudec, 2000.

167 Article 22.4, DSU.

${ }^{168}$ See Schefer, 2010, p. 149 and; Matsuchita; Mavroids; Schoenbaum, 2003, p. 87.
} 
If the complainant understands that it is not practicable or effective to suspend concessions within the same sector, the DSU allows the member to seek suspension of concessions or other obligations in other sectors under de same agreement. Finally, Article 22.3 (c) states that if the member (and the DSB) consider that the circumstances are serious enough and that it is not practicable or effective to suspend concessions or other obligations with respect to other sectors under the same agreement, the complaining party may seek to suspend concessions or other obligation under another covered agreement ${ }^{169}$.

Regarding the instrument of suspension of trade concessions, paragraph (c) of Article 22.3 is particularly important to this research. That paragraph upholds and allows the possibility of cross-retaliation under the WTO, which will be analyzed in the last item of this chapter.

\section{- $\quad$ Effectiveness of the Suspension of Concessions}

The effectiveness of the retaliation procedure is doubtful. It largely depends on the relative economic importance of the member adopting it, and it is more evident when the difference of economic power between members becomes clearer.

Although it can be said that it is common sense that the WTO dispute settlement mechanism has teeth to bite the members who do not comply with the decisions adopted, in reality the effectiveness of the suspension of trade concessions is challenged by the tremendous difference of market size that can be disputing in the playing field.

As suggested by the game theory, players will always try to take actions that secure them the best outcome. In that sense, a threat is credible to the players if they know that it will be concretized. That is where the problem resides and it is one of the core issues of the present dissertation.

The current 153 WTO Members have significant economic, social and political differences. Even though these aspects may help or hinder in the moment to suspend concessions, the economic and political aspects gain enormous emphasis at the moment of enforcing compliance with the decisions adopted by the DSB.

\footnotetext{
${ }^{169}$ Article 22.3, DSU.
} 
The same is true when a retaliation proceeding is approved. The political influence and the threat of great economic loss might impede the majority of WTO members (developing countries) of put in force a trade retaliation action.

Nowadays the developing countries represent the greater number of members of the multilateral trading system. Over the years, that group of countries has put forward several initiatives for the creation of agreements that could guarantee special treatment to them. For example, the creation of the United Nations Conference on Trade and Development UNCTAD -, that promotes a "development-friendly integration of developing countries into the world economy" $"$.

The participation of developing economies during the GATT 1947 used to be considerably reduced. A substantial reason for that was the weak bargaining power of the countries as well as the lack of legal security of the system, as GATT had a purely diplomatic and/or negotiating environment.

It is true that the situation has currently changed though. The developing countries are making use of the dispute settlement system with incomparable frequency, mainly as respondent. This is partially explained, according to Barral, by the increase of the competitiveness of that group of countries in the global market ${ }^{171}$.

The dispute settlement system is critically evaluated, especially where the implementation and retaliation procedures are concerned. Problems of implementation of DSB decision in the national level and, beyond that, the lack of instruments to effectively retaliate the losing part play a big role among the DSU problems.

Developing countries are specifically critical when it is necessary to induce compliance of a DSB decision against a developed and big market size economy. That issue is going to be addressed in detail in the next section.

The rate of compliance with DSB decisions is high ${ }^{172}$. Nevertheless, it is true that the high rate of implementation also takes into account implementations of decisions that were not fully implemented - because of an agreement or some kind of arrangement between

\footnotetext{
${ }^{170}$ See UNCTAD. Available at: <www.unctad.org/templates/Page.asp?intItemID=1530\&lang=1>. Last accessed in: 29 May 2011.

${ }^{171}$ Barral, 2004, p. 24.
} 
the parties. Yet, the number reflects the overall rate of implementation, not the rate of implementation taking into account developing countries as complainants and developed countries as respondents only. The latter is going to be further addressed below.

Since its establishment in 1995, the DSB dealt with 427 disputes (current number, January 2012) and from those, in eight disputes retaliation has been multilaterally approved. Namely, the disputes are: EC-Bananas, EC-Hormones, US - Gambling, US-Cotton Subsidies, US-FSC, US-Byrd Amendment, Brazil-Aircraft and Canada-Aircraft.

Although the GATT system required consensus to approve a retaliation proceeding (including the necessary approval by the violating member), it was not a very popular instrument. Then, most probably because of the need of consensus, from 1947 until 1995 retaliation was authorized only once during the GATT period ${ }^{173}$.

However, the WTO system works with an opposite logic. Although the retaliation proceeding shall also be approved in a multilateral forum, it works with a negative consensus. That means that if suspensions of concessions are considered equivalent and appropriate at the multilateral forum, they can be automatically and unilaterally put in action by the complainant.

There are different schools of thought regarding the effectiveness of the WTO retaliation proceedings. Even though authors like Alan Sykes defend that that system does not require fixing and works in a satisfactory mode, this position is not shared by most WTO researchers ${ }^{174}$.

Trade retaliation implies restriction of trade. Less access to markets, exclusion of trade concessions and the imposition of protective measures are some of the prejudices that can be visualized by the use of suspension of concessions. Those results are in a completely reverse sense from what was desired by the WTO agreement.

\footnotetext{
${ }^{172}$ As mentioned before, in a paper regarding the first ten years of the dispute settlement system, Davey presents an analysis that shows $83 \%$ of successful implementation of WTO decisions. No doubt, that is an impressive record for an international dispute settlement system. Davey, 2005b, p. 46-48.

173 See Bown; Pauwelyn, 2010, p. 2 and; Jackson, 2000c. p. 182. The GATT contracting parties authorized suspension of concessions under Article XXIII of GATT in a case brought by the Netherlands against the United States. The Netherlands alleged a GATT-inconsistent import restraint imposed by the United States on dairy products imported from the Netherlands.

${ }^{174}$ See Sykes, 2009. In this paper Sykes explains why he believes that the WTO system of dispute resolution has "evolved a reasonably defensible and satisfactory fashion in response to a number of competing pressures." Sykes understands that the system is not broken and does not require fixing. Sykes, 2009, p. 1-2.
} 
Due to the fact that restricting trade is not in accordance with WTO goals of trade liberalization and increasing access to foreign markets, trade retaliation is yet a controversial instrument. But that is not all.

More than producing trade restrictions, the DSU suspension of concessions has proved to be an ineffective instrument as it is (i) optional and (ii) it does not produce a real threat when the disputes have a developing country as complainant.

That fact is important not only because it is the central objective of the present research, but also because developing countries - as previously mentioned- are increasingly using the system as they possess a bigger share of the world market each day.

The effectiveness or the lack of it needs to be interpreted in parallel with the possible goals of the retaliation in the WTO. For that matter, Joost Pauwelyn makes an interesting interpretation about the goals of the suspension of concessions, dividing then in two major goals: compensation and sanctions.

The compensation goals, divided in withdrawal of the violating measure (rebalance) and/or compensation of damages are focused on the victim country. Differently, the sanction goal is focused on the violating country, and intends to induce rule compliance and/or to punish the violator ${ }^{175}$.

The understanding of the goal of retaliation in each case matters because it might have a material impact. It will influence the way in which the calculation and the design of retaliation should be defined to achieve the expected result. In any case, note that the suspension of concessions in accordance with the DSU has to be, besides effective, equivalent and appropriate regarding the level of nullification or impairment in question.

Notwithstanding, when there is an intention of sanctioning the violating Member, the DSB may be asked to consider a higher level of retaliation than the one established by Article 22.4 of the DSU.

Indeed, when talking about sanctioning the violator and considering a higher level of retaliation it would imply that when the compliant intends to induce compliance, it should be considered to take actions against sectors of economy where the violating member will be

${ }^{175}$ Pauwelyn, 2010a, p. 37-38. 
hurt the most. That includes politically sensitive products and/or the suspension of concessions in a different agreement (like intellectual property rights).

Pauwelyn explains that if the goal of the retaliation is to compensate the injured countries, the most appropriate benchmark may be the consideration of the loss of profits or economic harm suffered by the victims. On the other hand, if it is understood that the goal of the retaliation is to restore the balance of trade concessions between the economies involved, a proper benchmark could be the value of loss considering the bilateral flow of trade or trade effects $^{176}$.

Yet, the same author explains that none of these are the goals of the countermeasures, but the rebalancing of trade between countries, an equivalent level of trade should be set through the establishment, for example, of a prohibitive tariff keeping out as much trade as the original violation. And, finally, if the goal of the retaliation is to compensate the countries that were victims of the original breach, then it is understood that the retaliating Member should retaliate against specific sectors of economy or products that actually compete with its domestic industry ${ }^{177}$.

It is also worth commenting that all the remedies perceived under the DSU imply a prospective retaliation. That means that the remedies are only available after a long dispute process (which can take several years). The damages caused to the economy of the country affected by countermeasures / seeking countermeasures ??? can be, at the end of a dispute, irreversible.

Indeed, in actual practice the States only get compensation or exercise their right to suspend concessions prospectively. This implies that the illegal charge is maintained throughout the dispute settlement procedure.

In this regard, through a proposal by Mexico in order to clarify and improve the DSU, the country has put forth the possibility of adopting preventive measures in the event of serious injury, difficult to repair, the measure in question would be immediately suspended ${ }^{178}$. Actually, the possibility of adopting provisional measures already exists in the Anti-dumping Agreement and the Agreement on Subsidies and Countervailing Measures. They are applied

\footnotetext{
${ }^{176}$ See Pauwelyn, 2010.

${ }^{177}$ Id., p. 39.

${ }^{178}$ WTO, 2002, TN/DS/W/23.
} 
when the authorities concerned with the case judge that provisional measures are necessary to prevent injury being caused during the investigation ${ }^{179}$.

In possession of those measures, the members that would suffer damage which are difficult to repair would have the chance to have the contested measure suspended or to prevent a bigger damage otherwise. Also, it would eliminate the temptations of members to respond the contested measure by the imposition of further measures that could affect third parties.

In any case, suspending trade concessions or the application of countermeasures, as preferred, always means exclusion from markets or, at least, a much more difficult access to it. Depending on the dispute in question, a WTO case can have its negative effects spread to a great part of the multilateral trade system and many countries will suffer. More than other members, a country strongly depending on international trade will be definitely hurt more if subjected to countermeasures.

It is common sense that retaliation is, to a greater or lesser extent and depending on the market suspending the concessions, a shoot on one's own foot. Both the domestic market and consumers will suffer its effects, and if the economy in question is a poorer one, the application of countermeasures is definitely not an option ${ }^{180}$.

Although the rate of implementation of WTO decisions does not, at first, seem to be a big problem, the enforcement of decisions and the effectiveness of the mechanism of suspension of concessions are undoubtedly issues that concern Members.

The countermeasures as currently presented by the DSU are bad policy. Their enforcement is considered to be an even bigger problem, as those WTO members that can afford to pay the price for the violation will not be held responsible for the damage caused to the victims of their actions. Indeed, in 2000 Pascal Lamy (at that moment the EC commissioner responsible for international trade issues) gave an interview where he declared: "As long as you pay the penalties, you can go as you are"181.

\footnotetext{
${ }^{179}$ See Proposal by Mexico, TN/DS/W/23, p. 4. Also see Article 7 of the Anti-dumping Agreement (Agreement on Implementation of Article VI of the General Agreement on Tariffs and Trade 1994) and Article 17.1 of the Agreement on Subsidies and Countervailing Measures.

${ }^{180}$ See Matsushita; Mavroids; Schoenbaum, 2003, p. 92-93.

181 See Press and Communication Service Brussels, N. 3036, May 2000. See also Matsushita; Mavroids; Schoenbaum, 2003, p. 93.
} 
The issue of State responsibility is also a reason for concern. Even though the WTO is recognized as a treaty under public international law, it seems that there is a tendency to forget that fact. If a member decides not to comply with a WTO decision and affords to pay the price for it, its violating measures will continue to cause harm to other Members economies. Unfortunately that is how the system works, despite the widely advertised feature of WTO dispute settlement system having teeth.

International trade law - the WTO law - cannot be emancipated from general international law. International trade law is a department of international economic law which turns to be one of the branches of public international law. The specificities of WTO law do not justify a separated and different treatment of this branch of international law. That is so true that the WTO countermeasures, for example, reflect the general international law countermeasures $^{182}$.

Indeed, the countermeasures as they are presented by the DSU were designed from the customary practice of the countermeasures adopted under public international law. Still, the similarities between WTO countermeasures and public international law countermeasures, and the condition that the Organization actually recognizes countermeasures as a remedy makes it explicit that there is a correspondence and even a unit of the systems ${ }^{183}$.

That is why it has been suggested from the first chapter that a breach of a WTO obligation is, indeed, a breach of international law obligation. That is one strong assumption defended in this research. Moreover, with that belief, reparation and international liability should be considered and respected under WTO agreements, as all WTO law is placed in the context of international law.

Unfortunately, that does not correspond to the actual practice and that would be a theme for another doctoral dissertation. Nevertheless, State responsibility and its related matters will be addressed throughout the present research.

Preliminary, then, it is understood in this work that the effectiveness of the instrument of suspension of concessions as a remedy to breach of WTO obligations has weak or no force. The retaliation procedure can only take place when the Members involved in the dispute have relatively the (1) same economic force and (2) political influence. Beyond that,

\footnotetext{
${ }^{182}$ See Perez-Aznar, 2005.

${ }^{183}$ Ibid.
} 
the option to comply or not with the decisions adopted by the DSB, as it seems to be the understanding spread among members, does not encourage the obedience and enforcement of multilateral trade system rulings.

\subsubsection{Potential difficulties that should be considered in relation to implementation}

The implementation of WTO decisions brings to the discussion former notions of sovereignty and state jurisdiction. Members could be tempted to invoke State sovereignty as a shield of protection to avoid penalties of non-implementation of WTO decision.

When talking about international law it is also important to bear in mind that nowadays there is no State absolutely independent and that the notion of an international society of globalized nations is dominant, more than ever.

The States have the obligation with each other to repair the damage caused. That obligation is enshrined as a principle of Public International Law. As Ian Brownlie states, it is a principle of international law and even a general concept of law that any breach of an obligation requires reparation. Indeed, Brownlie states that the reparation of a violated obligation is an indispensable complement of a failure and for that matter there is no need for expressly convention ${ }^{184}$.

The discussion of breach of international obligation and State sovereignty leads to knowledge of the notion of international responsibility that has been brought in the first chapter of the present research endeavor. In that sense, Lafer indicates that the relation of international responsibility within the dispute settlement system of the WTO transcends the parties involved in a dispute as it relates to all WTO members ${ }^{185}$.

The author states that if the international responsibility is a response to a disruption of the balance of rights and obligations, and if the remedy to it excludes the obligation to compensate, that would be a strong diversification of international responsibility ${ }^{186}$.

\footnotetext{
${ }^{184}$ Brownlie, 1963, p. 437-438.

${ }^{185}$ Lafer, 1998, p. 134.

${ }^{186}$ Ibid.
} 
As mentioned in the previous section, the rate of compliance of WTO decisions is considerably high. Thus it would be normal to believe that there is no reason to worry about the WTO dispute settlement system.

Nevertheless, that rate has "obscure" data, as it includes for example cases of nonfully implementation, or agreement between States with a different solution than the one adopted by the DSB. Moreover, the rate number is general and does not focus on situations when the complainant is a developing country and the respondent a strong and developed economy.

Still, talking about compliance, it is important to keep it clear that (i) each case of non-compliance necessarily involves a huge amount of money and international trade restriction and (ii) the WTO was launched in the multilateral scenario to deliver security, predictability and fair trade for all its members, so compliance with its decisions should not be a problem. Nevertheless, that is not the case.

This section is going to address two issues that can be really problematic when the time arrives for enforcement of WTO adopted decisions: the acceptance of the binding effect of the recommendations and suggestions of the DSB and the economic asymmetry among Members in the playing field.

\subsubsection{Binding effect of DSB recommendations and rulings and Appellate Body reports}

The statement supported by WTO members - especially for those who lose the dispute - when implementing the decision is that the DSB recommendations and rulings are not binding. Thus, the violating Member would not be required to implement the decision within its jurisdiction nor would it have the obligation to harmonize their internal rules with a recommendation of a report adopted by the DSB.

That is not the interpretation defended in the present research. The WTO members have a pacta sunt servanda obligation according to which members agree to compulsorily 
award a third party to resolve their disputes related to trade, that is, the DSB ${ }^{187}$. Indeed, according to Davey, the obligations agreed by member States should be enforced by the WTO, without incurring in excess of power by this body ${ }^{188}$.

Moreover, although the decision of the panel or Appellate Body is called a recommendation, which can be understood as a mild term, it is widely accepted as having full binding force. As it used to be during the GATT period - when the value of the negotiated solution was more important than the rigors of litigation -, the rule is that the organs of the WTO dispute settlement limit themselves to a demonstration or not of the legality of the conduct in question ${ }^{189}$.

According to Hudec, the reforms resulted from the Uruguay Round were intended to strengthen the effect of the ruling of the dispute settlement. This author affirms that "the primary remedy set forth in the DSU is still the legally binding recommendation ordering the defendant to bring its conduct into compliance" ${ }^{" 190}$.

Corroborating with that interpretation of WTO recommendations and rulings, Mavroidis argues that the recommendations are definitely binding to the ones they are addressed to. On the other hand, he understands that the suggestions of a panel might not be binding.

However, Mavroidis states that the conclusion regarding the suggestions is not equivalent to a declaration that they are devoid of any legal consequence. In fact, if a WTO member follows a suggestion received, it will ipso facto fulfill its international obligations. Therefore, following the suggestions of the panels and the Appellate Body is a highly recommended legal strategy ${ }^{191}$.

\footnotetext{
${ }^{187}$ The pacta sunt servanda obligation can be found, for example, pursuant Article 23.2 of the DSU, that states: "not make a determination to the effect that a violation has occurred, that benefits have been nullified or impaired or that the attainment of any objective of the covered agreements has been impeded, except through recourse to dispute settlement in accordance with the rules and procedures of this Understanding, and shall make any such determination consistent with the findings contained in the panel or Appellate Body report adopted by the DSB or an arbitration award rendered under this Understanding". See also Mavroidis, 2003, p. 263.

${ }^{188}$ See Davey, 2001.

${ }^{189}$ See Lawson, 2003, p. 358-359.

${ }^{190}$ Hudec, 2002, p. 83.

${ }^{191}$ Mavroids, 2003, p. 274.
} 
Once a panel or Appellate Body report has been adopted the DSB, its recommendations and rulings become binding to the parties in a dispute and the losing respondent is required to bring its trade regime into compliance with the WTO rules.

Indeed, Jackson explains that the panel and Appellate Body reports seem to reinforce the rule orientation of the current multilateral trade system. Indeed, the author defends that the reports also reinforce the fact that the general principles of international law are applicable to the WTO and its agreements ${ }^{192}$.

Even though the DSU does not make it explicit that the content of the panel and Appellate Body reports have a binding effect, a number of clauses scattered in the text of the Understanding strongly imply, as Jackson states, the obligation to conform to a report in violation cases $^{193}$.

Before proceeding with the analysis of the binding effect, a clarification must be made. From the interpretation of the DSU, there are three types of legal actions regarding the WTO dispute settlement system: the violation cases, the non-violation cases and the situation cases. Briefly, a violation case refers to a case in which the DSB concludes that there is a real violation against WTO rulings. Also, in this case there is a presumption of nullification and impairment by a violation of a WTO agreement.

A non-violation complaint involves an internationally legal act. There is no breach of an international obligation and the attention is to a nullification or impairment, independently of trade damage. There is no requirement to withdraw the measure complained, rather the focus is on the effects of the measure, which shall be mitigated ${ }^{194}$.

In its turn, the situation complaints are hard to understand in the WTO context and there was no case that reported such complaints. As explained by Matsuchita, Mavroidis and Schoenbaum, GATT/WTO context injured parties can attack illegal (violation complaints) and legal measures (non-violation complaints). For that reason, the authors state that it is almost impossible to imagine how WTO remedies in such cases can be different from those

\footnotetext{
192 Jackson, 2000a, p.127.

${ }^{193} \mathrm{Id}$, p. 126.

${ }^{194}$ See Matsushita; Mavroidis; Schoenbaum, 2003, p. 85-86.
} 
applied to non-violation cases. Therefore, the forecast is that the situation complaints might disappear in the course of time ${ }^{195}$.

Returning to the discussion about the binding effect of panels and Appellate Body reports, Peter van den Bossche affirms that the recommendations and rulings are not legally binding by themselves. The author defends that they become binding "only when they are adopted by the DSB and thus have become the recommendations and rulings of the DSB"'196.

Van den Bossche goes on to explain that in addition to making recommendations and rulings, the report of the panel may make suggestion concerning the ways the Member could implement the recommendations. The suggestions, according to this author, are also legally binding for the Member concerned ${ }^{197}$.

It may be worth to make one last distinction regarding the DSB decisions. The recommendations will always come together with the adjudicating part of a dispute settlement decision referring to the illegality committed. Since the recommendations will always be an accompanying an adjudicating part of a decision regarding a breach of an international trade obligation, they will, as affirms Mavroidis, form an integral part of any adjudicating body decision ${ }^{198}$.

Although it can be argued that the DSU does not make the binding effect of recommendations and rulings of panels and Appellate Body reports explicit, several provisions of the Understanding clearly induce to conformity with what has been defended in this section. For example, pursuant Article 19, a panel or Appellate Body "shall recommend that the Member concerned bring the measures into conformity with that agreement". Article 21:1 states that "prompt compliance with recommendations or rulings of the DSB is essential in order to ensure effective resolution of disputes to the benefit of all Members".

As stated in Article 3:2 of the DSU and mentioned in the beginning of this chapter, the WTO dispute settlement system "is a central element in providing security and predictability to the multilateral trading system". That is the strongest intention that guided the creation of the WTO rule oriented system: security and predictability of trade relations.

\footnotetext{
195 Id., p. 84.

${ }^{196}$ Van den Bossche, 2005, p. 243.

${ }^{197}$ Ibid.

${ }^{198}$ Mavroidis, 2000, p. 781-782.
} 
Bearing that in mind, the binding effect of the recommendations and rulings also makes sense, even though it is not explicit in the body of the DSU. In accepting to make part of the multilateral trading system, members delivered a power of management and settlement of trade relations to the WTO. In believing that the system was built to favor and increase both trade relations and standards of life, members put their measures into conformity with WTO principles and agreed to respect its rulings and decisions.

Finally, the WTO enjoyed since its creation more power than GATT in enforcing bidding rules for all Members ${ }^{199}$. Therefore, the interpretation adopted in the present research is that the WTO binding rules are not only the agreements ones - valid to avoid problems such as free-riding -, but are also binding the rules translated into DSB recommendations and rulings.

\subsubsection{Economic asymmetry of WTO members: developing country sanctions harm themselves}

This section is going to discuss the most outward asymmetry related to trade relations, namely, the economic asymmetry. It will also discuss another disharmony that derives from or walks in tandem with the economic asymmetry: the political power. Both "power" asymmetries, implicitly or explicitly, significantly mark the differences (economic, cultural, social and political) of members in WTO discussions. And when the subject is the dispute settlement system and the implementation of decisions, these economic asymmetries play a bigger role.

One preliminary assumption of the present research endeavor is that the dispute settlement system does not solve the asymmetries among WTO members, and that problem becomes evident when the implementation of decisions adopted by the DSB takes place.

\section{- Asymmetric players}

${ }^{199}$ See Mutlus; Önis, 2007, p. 59-60. 
The term asymmetry, at first glance, may betoken a negative connotation and may be used to refer to a differentiation, a disharmony or an imbalance. Nevertheless, it is important to bear in mind that it is due to these asymmetries - economic asymmetry lato sensu - that changes in the trade between countries started to take shape.

With different products, different natural resources, different labor conditions and diverse specializations, countries are tempted to negotiate when they feel they are going to benefit from this negotiation. The international exchange of products, workers and knowledge supply the needs of a country, on the one hand, and promotes sales and income increase on the other ${ }^{200}$.

Still, along with specialization, asymmetries contribute to promote competitiveness and an increase of the interdependence of countries. With the increase of international interaction sales also increase and countries can increment their production scale, lowering the prices of products in the market. Producers have an income growth and consumers can buy more and with more options.

Moreover, besides economic power, asymmetries can originate from financial power, from international trade share or from technological innovations. As they are closely related, these categories of asymmetries are connected and may overlap. Also, more often than not they are a reflection of the wealth of a country.

Thus, it is true that economic asymmetries between countries have a positive impact since they support the integration of economies in order to achieve an overall income increase, among other purposes. Indeed, the WTO estimates that the impact of trade deals resulting from the Uruguay Round - considering margins for error and depending on the assumptions of the calculations - were between $\$ 109$ billion and $\$ 510$ billion were added to world income $e^{201}$.

Therefore there is strong evidence to support the claim that multilateral trade boosts economic growth for all the parties involved. Nevertheless that conclusion should not be reached hastily, without further analysis of the variables involved and impacted by multilateral trade.

\footnotetext{
200 The specialization of products was defended by David Ricardo in his theory of comparative advantages. According to this theory, each country should specialize in the productions that have a comparative advantage in cost, thus providing benefits for all countries involved in international trade. See Ricardo, 1978.

${ }^{201}$ Available at: <http://www.wto.org/english/thewto_e/whatis_e/10ben_e/10b06_e.htm>.
} 
It is noteworthy that in this section there is no ambition to delve into a deep economic analysis of asymmetries among WTO players. The intention is merely to shade light onto the benefits and problems that currently exist and which - to a greater or lesser extent -, influence the outcomes of the implementation of the dispute settlement decisions.

Regarding economic asymmetries, the scenario around the world can be extremely controversial. If the mathematical explanation of increased sales, plus scale production, lower prices and consumers buying, resulting in an overall growth of income were true for every WTO Member, economic asymmetries would be ideal situation for multilateral trade.

Nevertheless, there are significant differences among the economies of the 153 members. One does not need to go very far to understand that phenomenon. Take, for instance, the example of, the US and Burundi (one of the richest against one of the $10^{\text {th }}$ poorest economies of the world), both are WTO members, supposedly playing the same game in multilateral trade ${ }^{202}$.

In a 2006 publication, the World Bank recognized that due to imperfect markets, the asymmetries of power and wealth result in diverse opportunities. This leads to wasted productive potential and inefficient allocation of resources. In addition, the report indicates that the leveling of the global economy and political fields of action requires more equitable rules for the functioning of global markets and more actions to help create and maintain the funding of poor countries ${ }^{203}$.

Indeed, in what concerns the rules, although the legalization brought to international trade by the WTO helped (and still helps) to diminish the huge differences of WTO members once every country has to adapt its domestic rules to WTO standards, many elements remain unchanged. Forsooth, it can be argued that there is not much difference between GATT and WTO once the more powerful States are still the primary players in terms of drawing up and implementing multilateral trade rules ${ }^{204}$.

\footnotetext{
${ }^{202}$ It is true that the WTO and its Members provide special conditions for its least developed and developing Members, but these countries have to play in the same field of the richest Members, and that is where the economic asymmetries are evident. Here we can discuss an asymmetry of rules - such as the General System of Preferences and the different deadlines to implement WTO agreements - which can be an apparent advantage for the developing economies.

${ }^{203}$ See World Bank, 2006.

${ }^{204}$ See Mutlu; Önis, 2007, p. 57.
} 
As aforementioned, the WTO is truly a member-driven Organization, so much so that the Members are the ones to decide the directions of negotiations and its agenda. The Secretariat is clearly much more institutionalized than GATT, but the Members are the ones who are really responsible for shaping the multilateral trade.

In fact it should be clear that even though the decisions are made through multilateral negotiations in which all members are invited to participate, it is common place that informal negotiations (mainly among big players) are crucial for the decision-making process. Therefore, as stated by Mutlus and Önis, the multilateral character of the system is strongly undermined as the powerful developed and developing Members shape the rules in the name of other Members in the direction they wish ${ }^{205}$.

However, it is also true that without powerful economies the multilateral trade system would not have such a strong frame as it has nowadays. It is only with their financial and technical support that the GATT - and more recently the WTO - could be shaped and brought to life.

Surely because of the non-discrimination principles, the small economies that joined the WTO enjoy the benefits that all WTO members have. Likewise, small economies can form groups with similar or converging interests to improve their bargaining power during negotiations ${ }^{206}$. As an example of those coalitions under the WTO are: the ACP (African, Caribbean and Pacific countries); the African Group (all African WTO Members); the G-33 (also called "Friends of Special Products" in agriculture coalition of developing countries pressing for flexibility for developing countries to undertake limited market opening in agriculture); the G-90 (Coalition of African, ACP and least-developed countries) and; the Cotton-4 (Main African cotton producers) ${ }^{207}$.

Thus from a general perspective and taking an overall approach, every member experiences growth of income and trade benefits in their own economies as a result of joining the multilateral system.

\footnotetext{
${ }^{205}$ Ibid., p. 61. Further in the same paper, the authors also claim that "the lack of commitment on the part of developed countries to provide aid related to trade raises serious questions and points towards one of the major weaknesses of the current global trading order from a developing country perspective". Ibid, p. 64.

${ }^{206}$ It is important to notice that normally the least developed and the developing countries do not have an institutional and professional capacity to organize a strong bargaining opposition to defend their interests. Moreover, a recurrent problem is that they do not have converging interests to defend, making it difficult to find a consensus to negotiate together before the WTO meetings.

${ }^{207}$ More information available at: < http://www.wto.org/english/tratop_e/dda_e/meet08_brief08_e.doc $>$.
} 
Notwithstanding the problems of economic and political asymmetries are really apparent when the focus comes to the dispute settlement system. A look at the two tables below leads to the conclusion that there is a correlation between the most frequent users of the dispute settlement system and the countries with the strongest economies..

Table 1 displays the data of the ten biggest economies of 2011, according to the World Bank data on gross domestic product. The US, Japan, the richer European countries and three of the BRICs ${ }^{208}$ countries appear on the data, reflecting their impact on (or strength in) the international economy.

Also, according to WTO data, most of those countries in Table 1 are the current major multilateral traders. Indeed, the US, China, Germany and Japan are the leading importers and exporters, with a great market share of the international trade ${ }^{209}$.

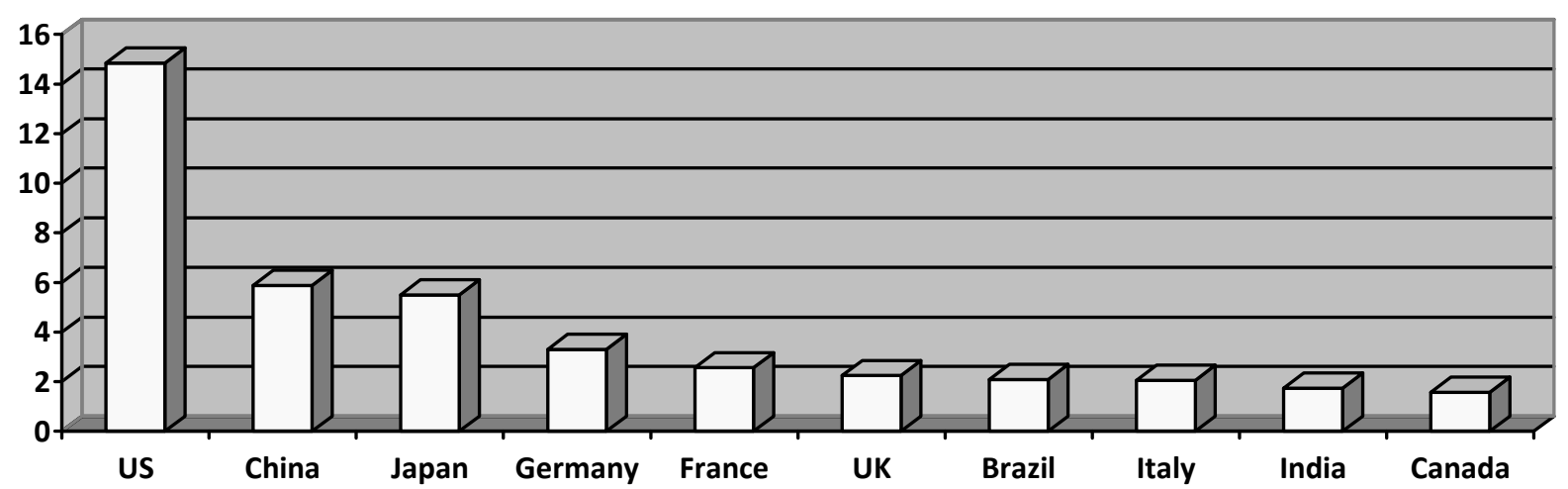

Table I - Source: World Bank GDP Indicators Database July $2011^{210}$.

Table 2 shows the ten major users of the WTO dispute settlement system and the number of cases in which they participate either as complainant or respondent (the participation as third parties was not considered relevant at this moment). Among the most

\footnotetext{
208 The term BRICs refers to the group of emerging giant market countries formed by Brazil, Russia, India, China and more recently South Africa. It is a political organization intended to coordinate countries to work together on economic issues and global affairs. They had their first official summit in 2009.

${ }^{209}$ More information available at: < http://www.wto.org/english/news_e/pres11_e/pr628_e.htm>.

${ }^{210}$ Source: World Bank, 2011. Gross Domestic Product 2010. Available at: < http://siteresources.worldbank.org/DATASTATISTICS/Resources/GDP.pdf>. Last accessed in: 04 Aug. 2011.
} 
active members in disputes, seven of them appear in Table 1 leading us to suggest that it is no mere coincidence that the most active members are also the most powerful ones.

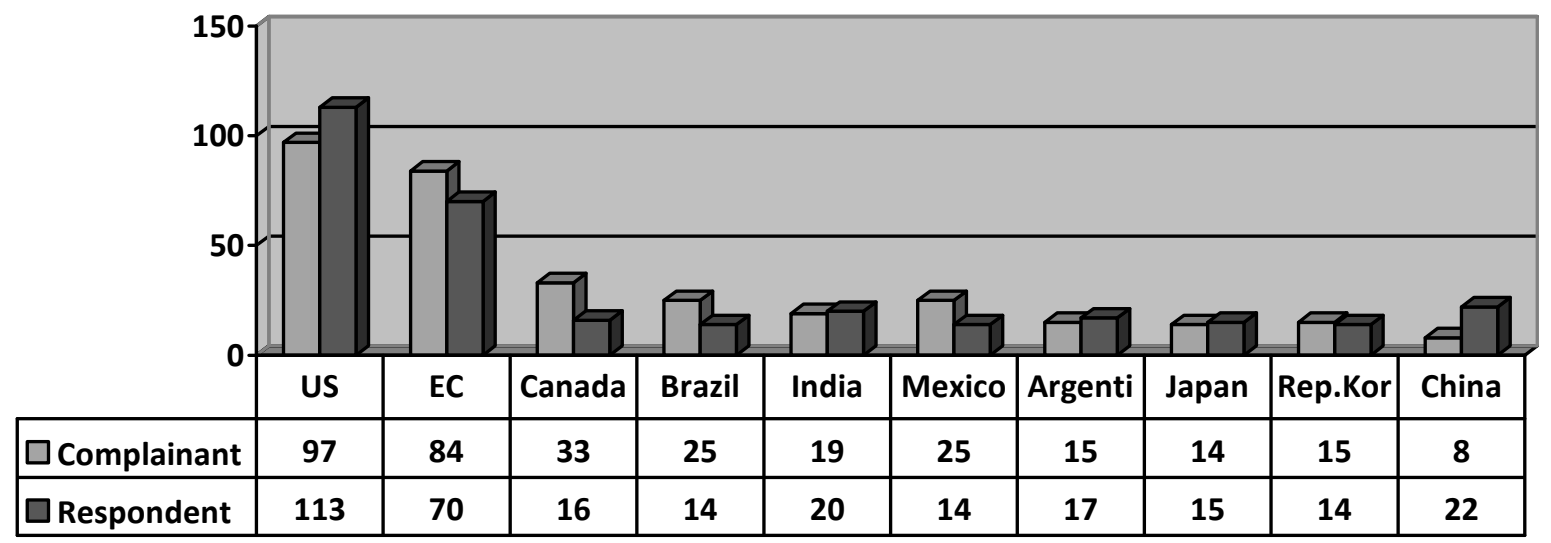

Table II - Source: WTO data on dispute settlement participation by country ${ }^{211}$.

First, given the fact that the biggest economies are the ones that have the greatest market share concerning international trade, it is reasonable to expect those countries to appear in a high number of disputes before the DSB. The major economies normally have trade relations all around the world with a high rate of exports and imports. Therefore they also represent the biggest consumer markets, confirming the idea that those economies are very important for the functioning of the whole system.

The dispute settlement system, despite its prominent status for the WTO, refers to a quite expensive procedure. For the majority of the developing members, litigating WTO cases may be prohibitively expensive do to their lack of institutional and financial means to pay the costs of representing their interests effectively ${ }^{212}$.

Although the price of litigating before the DSB is not the main focus of discussion in the present study, it is worth putting in a few words in this respect. As Busch and

\footnotetext{
${ }^{211}$ Source: World Trade Organization, 2011. Disputes by country/territory. Available at: < http://www.wto.org/english/tratop_e/dispu_e/dispu_by_country_e.htm>. Last accessed in: 04 Aug. 2011. For a complete statistical analysis on the WTO Dispute Settlement between 1995-2010, see Leitner; Lester, 2011.

${ }^{212}$ See Smith, 2004, p. 548-549.
} 
Reinhardt previously stated, the legal capacity to litigate in the WTO dispute settlement is a thorny issue ${ }^{213}$.

It is true that for WTO members to take full advantage of the system they have to be prepared to pursue their rights in a very competitive arena. For wealthy economies this is not a problem as they have financial means to expend in the procedure and well prepared professionals in the specific area of multilateral trade.

Nevertheless and as stated by Busch and Reinhardt, the situation is not the same for developing countries and the small economies of the WTO. So as to have the capacity to litigate in the WTO, countries need both experienced trained lawyers in a very specific field and staff and domestic institutions to monitor and participate in the multilateral trade, politicians and bureaucrats to decide whether it is worth litigating and, finally, as it is required and preferable, a local staff in Geneva to follow the negotiations closely ${ }^{214}$.

Clearly not all governments are able to provide the necessary instruments of an ideal situation. Considering WTO members, there is a considerable asymmetry of legal expertise and resources to use the WTO dispute settlement system.

Instead, in order to prepare and go forward with a case under the strict deadlines established by the DSU a country must have a high level of legal expertise and administrative capacity $^{215}$. Normally that is unthinkable for many of the WTO members, especially for the least developed countries, which have a big list of other urgent priorities to see to in their domestic arena. Indeed, in many cases is not even possible to keep special staff of representatives for WTO issues in Geneva.

Actually, in order to be capable to litigate, developing countries may sometimes rely on the direct financial and legal assistance of developed and powerful WTO members that obviously promote their own interests. This is not very common, but for example Shaffer reminds us that the EC "provided funds for fourteen ACP countries to hire lawyers in Brussels to defend their interests as a third party (and indirectly, the EC's interests as a party) in the EC-Sugar case brought by Brazil and Thailand"216.

\footnotetext{
${ }^{213}$ See Busch; Reinhardt, 2003; Id., 2004.

${ }^{214}$ Busch; Reinhardt, 2004, p. 3.

${ }^{215}$ See Smith, 2004, p. 548.

${ }^{216}$ Shaffer, 2009, p. 177. EC-Sugar refers to the dispute DS266, available at: http://www.wto.org/english/tratop_e/dispu_e/cases_e/ds266_e.htm>.
} 
The fact that most of WTO members have neither the aforementioned legal expertise nor the administrative capacity to present a dispute corroborates the data shown in Tables 1 and 2 above. Wealthier economies are far more prepared to litigate under the DSU rulings whereas developing countries lato sensu do not progress in terms of experience regarding the WTO dispute settlement system.

Nevertheless, developing countries such as Brazil, India and China are becoming active users of the system as their economies are progressively and promptly acquiring a bigger market share worldwide ${ }^{217}$.

It is important to say that even though those countries are considered developed economies, they are in a different baseline from the majority of the developing members. Therefore, it is understood that the market size and the expertise acquired by Brazil, India and China in using the dispute settlement system is unique and represents a separate reality from the developing economies of the WTO. That is why, for instance, not only Brazil, India and China are able to comply with DSU rulings and deadlines, but they can also represent a real threat to the powerful economies during litigation and eventual retaliation procedures.

Thus one can conclude that although the dispute settlement system works for all complainants, it surely works better to complainants who can take full advantage of the legal opportunities of the system with their expertise and administrative preparation ${ }^{218}$. That reality is also true regarding the work under all the other WTO agreements: the members who are better prepared are more likely to take full advantage of the opportunities that the multilateral trade can open.

\section{- Developing country sanctions harm themselves}

It is true that the lack of legal expertise and administrative capacity coupled with the lack of financial conditions to litigate under the DSU rulings represent one major problem for the effectiveness of the dispute settlement system.

\footnotetext{
${ }^{217}$ In the case of China, the country has participation in a great number of cases as third party, in order to gain legal expertise in the dispute settlement system of the Organization.

${ }^{218}$ See Busch; Reinhardt, 2004, p. 5.
} 
Moreover, it can be claimed and was in fact suggested by Busch and Reinhardt, that this problem may harm the whole system. The deficiencies of developing countries undermine the well-functioning of the dispute settlement once it incites cheating in the system and a disincentive on the part of developing countries to negotiate ${ }^{219}$.

The problems that appear in a more advanced stage when the dispute is already ongoing also bring strong worries to WTO scholars, staff and members. The aforementioned problems are at least as worrisome as the legal capacity. The implementation phase and WTO remedies are in the core of discussions about the reform of the dispute settlement system.

In accordance with Hudec, developed countries are somehow privileged by the lack of an efficient mechanism that binds the compliance with DSB decisions. Therefore, developed countries normally argue that the disciplines to substantially change the mechanism of implementation of the WTO decisions are ineffective ${ }^{220}$.

Indeed, since 1995 experience shows that the problem of lack of instruments to induce implementation of a decision adopted by the DSB currently remains one of the biggest challenges for the use of the system by modest economies ${ }^{221}$.

Considering all the instruments available in the dispute settlement system, it can be affirmed that it is, in several ways, more favorable to the larger economies of the WTO. Important consumer markets such as the US and European countries represent a much higher and efficient pressure when considering remedies applied by those countries against developing countries. The other way around is also true. The impact of the remedies tried by developing country members is quite insignificant when the dispute is against a big market.

Yet, the possible applicable remedies by the developing countries damage their domestic economy more than impact the defendant. It is easy to comprehend that since those countries are normally strongly dependent on developed markets to improve their own economies. It can be claimed that powerful economies still abound ${ }^{222}$.

Not only the economic impact is harmful to the developing countries, but also, and perhaps more importantly, they bring heavy problems and restrictions in other fields of

\footnotetext{
${ }^{219}$ Busch; Reinhardt, 2004, p. 7.

${ }^{220}$ See Hudec, 2000, p. 346-349.

${ }^{221}$ Amaral Júnior, 2006, p. 85. The author adds that until 2006 no African country had means to be represented in the dispute settlement system as a complainant.

${ }^{222}$ Id., p. 86.
} 
international affairs once retaliations are essentially a political weapon. Indeed, as countries are increasingly interdependent, a political problem originated in a retaliation procedure can generate discomforts and multilateral reprisals regarding other issues.

Preliminarily and as stated by Joost Pauwelyn, trade retaliation does not work when developing countries win a case. And although that affirmation is a result of the analysis of several aspects that influence the implementation (or not) of the DSB recommendations and rulings, the effectiveness of the countermeasures does depend on the relative economic importance of the member adopting them ${ }^{223}$.

That claim is far from the statement that legal complaints by developing countries are not useful. Even if, as discussed here, the retaliation option is not available or not as appealing as desired, complaints presented by developing countries are effective policy tools 224 .

Forsooth, the legalization of procedures that came with the creation of the WTO made legal complaints a bit more effective than they were during the GATT, and the usefulness of the system is not in question ${ }^{225}$. Moreover, the legalization of the system has the potential to operate in favor of developing countries, at least when compared to the unrestricted bargaining instruments used until $1994^{226}$.

However, turning over to the last part of the dispute settlement procedure, the implementation phase and the current remedies under the DSU do have their effectiveness undermined in the specific situation when a developing country has the right to suspend concessions against a developed member.

WTO system of retaliation is basically a political instrument of pressure and as such, to be effective, trade retaliation must be a credible threat (keeping in mind the game theory). The respondent must feel that in non-complying with a DSB or panel decision, it is going to suffer prejudicial trade restrictions on the part of the complainant.

Now, considering the simple data that was presented above it is hard to imagine how an average developing country and/or small economy can ever present a threat to a

\footnotetext{
${ }^{223}$ See Pauwelyn, 2010 and; Matsushita; Mavroids; Schoenbaum, 2003, p. 92-93.

${ }^{224}$ See Hudec, 2002

${ }^{225}$ Ibid.

${ }^{226}$ See Smith, 2004, p. 549.
} 
developed market. Normally the developing members are highly dependent on developed members to feed their own domestic economy.

Notice that the term average is used here to address to standard developing countries excluding international powers such as Brazil, India and China, which definitely belong to a separate category. Although they are evaluated as developing countries those countries occupy a respected position among the ten most powerful economies in the world ${ }^{227}$.

Therefore, due to their differentiated position regarding industry, agriculture, innovation, knowledge and of course their important consumer markets, those countries have means of opposing a real threat to developed members and thus get better results in return.

Thus, if the complainant developing members cannot expect compliance by a respondent developed country, there is a problem. Even though retaliation is allowed, it does not make any difference if the complainant harms itself by going forward with suspension of concessions and trade restrictions against a huge economy (which the developing country is probably dependent on).

This is where the famous expression among WTO scholars which says that trade retaliation is 'shooting yourself in the foot' fits perfectly. It is also where the heaviest discussions about the effectiveness of DSU legal remedies take place.

Although it is true that it is better to have a legalized framework as the WTO dispute settlement system than have no system at all, the lack of better remedies in the implementation phase does undermine the effectiveness of the dispute settlement.

Yet, as suggested before, it does not mean that developing country members should feel discouraged to use the system (as they may understand that this is likely to reduce their welfare). Every dispute brought before the DSB has had at least a political effect. Likewise the disputes shade light onto problems and inconsistencies in the system that may be undermining the work of the WTO for several members, in several sectors.

Still, an effectiveness problem exists regarding the implementation of the decisions adopted by the WTO.

\footnotetext{
${ }^{227}$ All three countries, although they have a high market value of their final goods and services (gross domestic product), they still have heavy domestic problems. For instance Brazil - an upper midle income level according to the World Bank - has a high rate of poverty and unemployment. India, considered a lower middle income economy, has only $54 \%$ of urban development (sanitary facilities) and $63 \%$ of literacy rate. China, also
} 
Although WTO disputes have a high rate of compliance by the respondents, every non-compliance case resulting from a non-implementation or a non-full implementation of WTO decisions is evidence that there exists an imperfection in the multilateral system.

Moreover, as there is no remedy to make the non-compliant respondent liable since the respondent can choose to pay the price to keep with its inconsistency measures - a red light must be signalized.

It is true that the rate of compliance with WTO dispute settlement decisions when a developing country Members is the complainant and a developed country members he respondent is comparable to the overall rate of implementation of $83 \%$ to $85 \%$.

The study by a Counselor of the WTO Legal Affairs Division, Reto Malacrida, suggests that in cases where the complainant is a developing country or a small economy, the compliance estimate maintains the high rate ${ }^{228}$. Thus, the compliance with WTO decisions seems to be successful even when small economies are sitting in the complainant seat.

Nevertheless, Malacrida calls the attention to the disputes of US-Gambling and EC-Bananas as two non-satisfactory implementation cases that made a huge noise in the WTO. Those cases will be discussed in detail in the next chapter. Besides those disputes, there are clearly several examples of cases - also very important ones - involving the relation of a developing country as a complainant and a developed country as a respondent, where non-implementation was prolonged ${ }^{229}$. The postponement of implementation or the nonimplementation in the cases where it was observed appears to have been stimulated by the market share and economic importance of the complainant member.

Even though the threat of retaliation has not played a central role in all cases in the decision of implementing or not a DSB or Appellate Body ruling, formal threats are important in the decision to comply ${ }^{230}$. The respondent will always take in consideration what he will gain or lose when complying with a decision. And even if the decision to comply does not have much to do with the complainant, the lack of power to present a credible threat by

an upper midle income economy according to the World Bank data, has deep problems with labour protection. For more information please see: $<$ http://data.worldbank.org/country $>$.

${ }^{228}$ Malacrida, 2008.

${ }^{229}$ Malacrida, 2008, p. 20. The disputes in which no compliance was achieved include for example US-Section 110 of the US Copyright Act, EC-Hormones and US- Anti-Dumping Measures on Certain Hot-Rolled Steel Products from Japan.

${ }^{230}$ Compliance and the elements that influence it will be further discussed in Chapter 4. 
the complainant influences (a lot in some cases) the respondent's decision to pay the price of keeping with inconsistent measures.

Retaliation measures are distortions on trade relations normally translated into additional customs duties on goods originating in the territory of the responding member. Depending on the targeted goods and the tariff rate imposed on them, the importers of goods coming from the complainant member market can either charge higher prices or stop importing due to the elevated costs ${ }^{231}$.

That partially explains the relative lack of enthusiasm among many WTO members regarding the procedure, since they are normally very reliant on imports from developed countries to push their own domestic economy. Holding on in a retaliation process may head to huge economic costs in the internal market and consequent detrimental effects on consumers welfare.

Most WTO scholars would agree that "countermeasures are a more or less ineffective instrument in the hands of smaller players" $" 232$ and that "trade retaliation simply does not work when developing countries win a case"233.

Since the aim of retaliation is to bite the respondent member and induce its compliance, most individual developing countries cannot achieve that goal. Normally developing countries have only a small share of the respondents' market, which in turn is incapable of producing any harm in the economy of the latter.

In sum, retaliation measures from developing countries will be counterproductive and most likely will not cause any pressure. Instead, they will probably result in even worse prejudice than the inconsistent measures that gave rise to the dispute. On the other hand and using the same logic, retaliation by larger members tends to be much more effective when used against small economies regarding their market size advantage $\mathrm{e}^{234}$.

\footnotetext{
231 See Malacrida, 2008, p. 11-13. Chad Bown and Joost Pauwelyn suggest ways of making retaliation more effective for developing countries by observing developed countries performance. The authors state that "the general guidelines for such 'smart sanctions' should be to (i) minimize the harm caused to the sanctioning country, while at the same time (ii) maximize the impact of the sanctions in the violating country. A crucial way to minimize harm at home is to conduct internal consultations with stakeholders (especially importers) before actually imposing sanctions. In this way, products sourced from the violating country which cannot be easily replaced by imports from other countries can be identified and avoided." In: Bown; Pauwelyn, $2010, \mathrm{p}$. 11.

${ }^{232}$ Bagwell; Mavroidis; Staiger, 2004, p. 14-15.

${ }^{233}$ Bown; Pauwelyn, 2010, p. 9.

${ }^{234}$ See Hudec, 2002, p. 83-84.
} 
Indeed, as Malacrida states and as suggested before, the current retaliation measures in the form of additional tariff duties go in the opposite direction of raising standards of living. Instead they raise new barriers for the multilateral trade. This is exactly the inverse of what is intended by the preamble of the WTO agreement which proclaim "a view to raising standards of living, full employment and a large and steadily growing volume of real income and effective demand" ${ }^{235}$.

Thus, considering the picture of small economies as complaints and developed countries as respondents, the detrimental effects of WTO retaliation system will normally cause much more harm to the retaliating member. Certainly, as stated by Charnovitz, "perhaps the biggest disadvantage of WTO sanctions is that they bite the country imposing the sanction" ${ }^{236}$.

The case of Antigua and Barbuda (hereinafter Antigua) against the US provides a good example of the difficulties to retaliate. The market size asymmetry between the two WTO members is significant - Antigua is one of WTO smallest members -, a standard which would mean that retaliation of suspension of tariff concessions by the complaint would have no impact on the economy of the US. In practical terms, the US could easily shift the small volume of trade it has with Antigua elsewhere. The same approach was taken in the ECBananas case, which will be deiscussed in the next chapter.

As noted, it does seem that the traditional means of retaliation by suspending trade concession is not a practical (feasible) option for developing countries. The incapacity to offer a credible threat and/or the problems that they may cause to its own domestic economy by retaliating are enough reasons not to make use of retaliation.

However, the WTO system is not structured to exclude Members taking full advantage of its instruments. The WTO system is meant to promote a fair multilateral trade with fair conditions for all players.

Poorer countries are definitely less likely to get what they want from the WTO dispute settlement system. Indeed Busch and Reinhardt agree that the legalized system of the WTO has exaggerated the gap between developing and developed country members concerning the ability to get defendants to liberalize dispute policies. In short, the authors

\footnotetext{
${ }^{235}$ See WTO Agreement and; Malacrida, 2008, p. 13.

${ }^{236}$ Charnovitz, 2002, p. 621.
} 
state that "wealthy complainants have become significantly more likely to secure their desired outcomes under the WTO, but poorer countries have not"237.

The retaliation pursuant the DSU has imperfections that are clear to everybody when a developing country is playing as complainant. It is in the implementation phase that most of the reform proposals for the DSU rely on. Although it will not work for all members, a cross-retaliation option may be a solution in some cases as explained in what follows.

\subsection{Compliance at the WTO}

The first subsection introduces the role of compliance in the international scenario. With the aim of exploring the reason why states comply with international rulings, this section addresses basic issues explaining why states obey (or not) international law. As previously outlined in the opening sections of this study, the WTO is an international organization set by a treaty of international public law. Therefore, WTO law is a branch of international economic law, which in turn is a branch of international public law. As such, concepts and principles of international law guide the function of the WTO.

This section of the study deals more closely with compliance at the WTO. A fact that is well known and was addressed before in this research endeavor is the high compliance rate at the WTO, which is significantly higher than that of other international organizations. Notwithstanding the high compliance, there is still comfortable room for Members that do not wish to comply with the DSB recommendations and rulings, which goes against the intention of the WTO. The Organization was created with the aim of structuring a legal and extensive framework for multilateral trade in order to promote the system security and predictability. At the same time, the Organization is thought to increase the standards of living of all of its members and promote a more balanced trade. Every decision not complied to represent losses (financial and social) for the affected) member (s). Also, every decision not complied to shows the WTO and its members that the system is not perfect and changes urge.

Central issues of this study are addressed in order to verify the extent to which they are related to the decision to comply (or not) with DSB recommendations and rulings. Economic asymmetry seems to play a significant role in the bargaining power and threat

\footnotetext{
${ }^{237}$ Busch; Reinhardt, 2003, p. 728-729.
} 
process in the retaliation phase. Whether the economic power of a country can really affect the decision of a respondent to comply or not in a dispute involves a discussion with arguments towards both streams, positive and negative.

\subsubsection{Compliance and International Law}

A general definition of compliance in international law could be the conformity of an action/behavior of a subject of international law and the specific rule. Indeed, as already stated, most theories of compliance with international law are normally underlying theories of the behavioral influence of legal rules ${ }^{238}$.

Although the focus of this study is the legal rule, namely, WTO law, compliance in international law is not only applicable when a legal framework exists. It can be applicable, for example, to customary law, which is also a source of international law according to the Vienna Convention on the Law of Treaties.

Compliance is very closely connected to implementation of the rules of a system and, in consequence - one could think -, with the effectiveness of the system. Even though these are connected concepts, compliance and implementation do not depend on each other. Compliance can exist without implementation. As stated by Raustiala et.al, while implementation is the process of putting international commitments into practice, compliance can occur without any effort or action by a regulated entity ${ }^{239}$. In the same vein, the connection between compliance and effectiveness is not necessary. Rules and legal regimes can be effective even if compliance is low. The same authors still state that:

And while high levels of compliance can indicate high levels of effectiveness, they can also indicate low, readily met and ineffective standards. Many international agreements reflect a lowest common denominator dynamic that makes compliance easy but results in a negligible influence on behavior. Here is the source of the vexing question of the significance of high observed levels of compliance. ${ }^{240}$.

${ }^{238}$ Raustiala; Slaughter, 2002, p. 539.

${ }^{239}$ Ibid. The authors give the example of the Soviet Union, where the collapse of its economic system has resulted in the compliance of the Union with many international environmental agreements. 
Whether this is the case of WTO Members - easy compliance plus bad behavior , that is an issue to be questioned. It does not seem to be the case for easy compliance, since (i) the DSU is quite demanding and (ii) the issues dealt in the WTO disputes are normally not easy. Nevertheless, it seems to be the case that there exists a number of examples of bad behavior of Members, especially the ones which can abuse their power position in the multilateral trade such as is the case of the US. Even if WTO powerful members comply, the case of partial compliance or negotiated compliance is very often observed in the system, contributing to the overall high rate of compliance.

Notwithstanding, considering general international law with all its organizations and institutions, it seems that Henkin was right when he wrote decades ago: "it is probably the case that almost all nations observe almost all principles of international law and almost all of their obligations almost all of the time"241. If that was not true, governments and organizations would not spend so much time - sometimes years - and resources trying to agree on treaties and set rules for the behavior of States in the international environment. And that works in the same logic in the national level, as governments work with the assumption that the law created will be observed ${ }^{242}$.

Since States started to form partnerships and groups or organizations in order to be more connected and then more interdependent, the culture of compliance appears to be following the process. Especially with the institutions created after the Second World War, and with the increasing flexibility it brought to national sovereignties, the compliance with international legal system has gained force.

Nevertheless, it is important to note that in considering compliance one could find a large number of variations depending on, for example, the time of agreement, the country concerned and the interests involved. Indeed, as rightly shown by Haas, not all States comply with the same instruments, the same State may vary in its own compliance according to different legal instruments across different sectors and different patterns ${ }^{243}$.

According to Henkin, States comply because of internal motivations and external inducements. For him, internal motivations to comply are nowadays weaker than before, but

\footnotetext{
${ }^{240}$ Ibid.

${ }^{241}$ Henkin, 1979, p. 47.

${ }^{242}$ See Henkin, 1995.

${ }^{243}$ See Haas, 2000 , p.44.
} 
they still play an important role. States have - normally - a developed sense of commitment to the international order and stability in the international society. Indeed, it is true normally that States have the notion that "stability, law and order, reliability (and a warrant reputation for reliability) are in their national interest, and therefore they have a more-or-less enlightened self-interest in compliance" ${ }^{244}$. The basic understanding is that the international laws with which the States agree are in their self-interest and therefore it is somehow expected that the States will be willing to comply.

Moreover, there is a strong belief that States keep commitments because they fear that if there is evidence of their unreliability, which might damage the cooperative relationships they are engaged in and, in consequence, that may reduce other States (partners) willingness to enter into future agreements. As Downs et.al. explain, once the opportunity costs resulting from the cooperation are normally substantial, most of the States are very much stimulated to behave cooperatively ${ }^{245}$.

On external inducements, as according to Henkin, they are the principal stimulus to comply with international commitments. Therefore the main contributors to a culture of compliance are external factors. As international law is horizontal by definition - since States and sovereignty are theoretically equal - enforcement of international commitments are also horizontal. In fact, the possibility of horizontal enforcement exerts a powerful deterrent influence, which in many cases is reflected in a strong threat of retaliation ${ }^{246}$.

Current and collective horizontal inducements to compliance shall be considered taking into account the great number of multilateral and regional treaties and understandings among countries. At the same time, international rulings gradually indicate more obligations that shall be applied erga omnes and the breach of these obligations may have its consequences reach more than one State.

Peter Haas built a table $\mathrm{i}$ indicating the likelihood of a State compliance. Assuming that countries are capable of enforcement, Haas indicates that the willingness to

\footnotetext{
${ }^{244}$ Id., p. 49.

${ }^{245}$ See Downs; Jones, 2002, p. 96. In the same place the authors point out that there is "empirical evidence to suggest that the impact of reputation is either weaker or more complicated than much of the theoretical literature suggests. While compliance rates are relatively good in general, they are often considerably lower than one would expect them to be if every defection had important implications for every current and future agreement. This is true even if we allow for the effects of imperfect information". Ibid.
} 
comply may vary depending on the political costs of (non) compliance. The table is reproduced below.

\begin{tabular}{l|c|c}
\multicolumn{2}{c|}{ costly compliance } & not costly compliance \\
\hline State is capable and willing & \multicolumn{1}{|c|}{ Possible } & Most likely \\
\hline State is capable but unwilling & \multicolumn{1}{|c}{ Unlikely } & Unlikely \\
\hline $\begin{array}{l}\text { State is Incapable and } \\
\text { Unwilling }\end{array}$ & $\begin{array}{l}\text { State may try to comply and } \\
\text { expect to fail in order to } \\
\text { attract resources from } \\
\text { international institutions to } \\
\text { improve capacity }\end{array}$ & State may try to comply \\
\hline $\begin{array}{l}\text { State is incapable and } \\
\text { unwilling Highly unlikely }\end{array}$ & Unlikely \\
\hline
\end{tabular}

Table III: Likelihood of State Compliance ${ }^{247}$.

Probably, the key to understand variation in compliance decisions by States is related to the nature of the subject in discussion, the costs to the domestic society, domestic market, domestic industry and the political costs of the implementation of compliance or not in the view of the international society. Also, Haas highlights that compliance with international obligations depends on threats of sanctions for non-compliance levied by a powerful State ${ }^{248}$.

Not surprisingly, there is a study made by Guzman, which explains compliance by States based on the (credible) threat of retaliation. This approach seems to be very adequate in what concerns the dispute settlement system of the WTO and the (non) compliance by its members of DSB decisions. The aforementioned author understands that a model of compliance with international law requires a system through which nations that breach international obligations are sanctioned ${ }^{249}$.

\footnotetext{
${ }^{246}$ See Henkin, 1995 , p. 50. In what concerns sovereignty of States in current international law, it shall be recognized that that the transformation of sovereignty has remade international law, so that international law rulings now seems to help to construct national identities and interests. See Koh, 1997, p. 2602.

${ }^{247}$ Source: Haas, 2000, p. 47.

${ }^{248}$ Id., p. 51.

${ }^{249}$ See Guzman, 2002.
} 
With a simple prisoner's dilemma it is possible to visualize - without the burden of considering all the variations that one single situation can present -, what can happen. Taking as inspiration Guzman's work, one could assume that regarding WTO agreements (i) each country is better off if it violates the agreement while the other country complies; (ii) both are better off if they both comply rather than if they both violate and; (iii) the equilibrium is for both States to violate their international obligations.

\begin{tabular}{|l|l|c|c|}
\hline \multirow{4}{*}{ Country 1 } & \multicolumn{3}{|c|}{ Country 2 } \\
\hline & & Comply & Violate \\
\cline { 2 - 4 } & Comply & 5,5 & 2,6 \\
\cline { 2 - 4 } & Violate & 6,2 & 3,3 \\
\hline
\end{tabular}

Table VI: Prisoner's Dilemma ${ }^{250}$

International law, as shown in the prisoner's dilemma presented above, seems to play a minor role in States decisions. If that is true, Guzman is right (and this is also the understanding of this analysis) that a model in which international law does matter should identify effective mechanisms to sanction the violations committed. To change the result of the game, a coercive compliance mechanism should exist. Even the WTO, and Organization well known for its teeth to bite violators, does not provide an effective mechanism of sanctions. And sanctions include all costs resulting from the breach, "including punishment or retaliation by other States, and reputational costs that affect a State's ability to make commitments in the future" ${ }^{251}$. As said before, international law affects the State self-interest, which, according to Guzman, may result in two different impacts on the decision to comply:

First, it can lead to the imposition of direct sanctions such as trade, military, or diplomatic sanctions. Second, it can lead to a loss of reputational costs of violating international law are outweighed by the benefits thereof, a state will violate that $\operatorname{law}^{252}$.

\footnotetext{
${ }^{250}$ Source: Guzman, 2002, p. 1842.

${ }^{251}$ Id., p. 1845.

${ }^{252}$ Id., p. 1846.
} 
As previously suggested in this section, reputation is an important element that is normally taken into account in the decision to comply. A decision to violate an international agreement may be beneficial to the violator in the present, but may reduce its payoff in the future. This also explains why States have incentives to comply in some situations and pay the price of noncompliance in others. Nevertheless, the statement that "by developing and preserving a good reputation, States are able to extract greater concessions for future promises"253 is completely right.

Yet, there is evidence that States decision to comply is influenced by their enrollment in an international institution. Keohane defines international institutions as "persistent and connected set of rules (formal and informal) that prescribe behavioral roles, constrain activity and shape expectations" ${ }^{254}$. Haas assumes that international institutions encourage States compliance and somehow deterred non-compliance by eliminating or diminishing barriers to self-interests of its members ${ }^{255}$.

It cannot be forgotten that by assuming the obligations set out by signing the participation in an international organization, States are assuming pacta sunt servanda obligations, which are made in good faith and are binding. To be bound by international obligations voluntarily signed, at least gives the impression that States are willing to comply with whatever decision taken by the organization and its members.

In that sense, Bilder states that the character of the international system, broadly understood as horizontal, and the firmly-held notions of State sovereignty leads to a belief that international rules are normally developed and implemented by consensus rather than through authoritative processes. The consequence referring to compliance is that in norms decided by a voluntary process, States shall be willing to conform their behavior to the rulings of the organization they are part of ${ }^{256}$.

\footnotetext{
${ }^{253}$ Id., p. 1886.

${ }^{254}$ Keohane, 1989, p. 3.

${ }^{255}$ See Haas, 2000, p. 53.

${ }^{256}$ See Bilder, 2000, p. 66.
} 


\subsubsection{Compliance at the WTO: is it an option?}

The title of this section was inspired by a conversation with the current Director of the Intellectual Property Division of the WTO, Anthony Taubman ${ }^{257}$. While discussing crossretaliation and compliance issues, Taubman commented that the present research endeavor should shed light on (i) the nature of compliance and (ii) whether there is an option available to members to comply with the DSB decisions.

Given the aforementioned comment, it seems worth questioning if it really is just an option opened to the Members or that compliance must be observed. Moreover, one can question whether WTO law has a long-term impact on the behavior of Sates. A reflection made by Peter van den Bossche - currently Member of the Appellate Body of the WTO -, poses the question of whether the culture of compliance is truly brought about by the legal structure of the WTO system ${ }^{258}$.

In a first look conclusion, one could be tempted to answer yes, due to the high rate of $83-85 \%$ compliance with WTO decisions. Nevertheless, and as addressed before, these numbers do not indicate full compliance, nor prompt compliance in all cases, nor that the $15 \%$ of noncompliance shall be dismissed. Indeed, every instance of noncompliance with the DSB and/or Appellate Body recommendations is very problematic.

What Davey calls "quality compliance actions" indicating the successful compliance cases at the WTO shall meet two requirements: (i) the implementation of DSB recommendations in accordance with the actual decision and (ii) the withdrawal of the inconsistent measure. Yet, when one looks at the quality and the timeliness of compliance actions, the scenario is anything but sound at the $\mathrm{WTO}^{259}$.

Under the DSU, Article 21.1 defines that: "Prompt compliance with recommendations or rulings of the DSB is essential in order to ensure effective resolution of disputes to the benefit of all Members". From the reading of the Article it is quite clear that

\footnotetext{
${ }^{257}$ The interview with Anthony Taubman took place at the WTO Headquarters, Geneva, March 2011.

${ }^{258}$ Interview with Peter van den Bossche. WTO Headquarters, Geneva, March 2011.

${ }^{259}$ Davey, 2009, p. 119.
} 
compliance is not an option, but an obligation that shall be observed in order to ensure the effectiveness of the system ${ }^{260}$.

One can observe that the WTO has its weak reed in those occasions in which the Members decided not to comply - or decided to comply without quality - with dispute settlement decisions. According to Coleman et.al. the noncompliance at the WTO has normally taken three forms, namely: (i) prior noncompliance; (ii) delay and; (iii) noncompliance, open and disguised ${ }^{261}$. The authors use the termination prior noncompliance to indicate that many WTO members - and not only the big players - , have taken measures knowing these to be inconsistent with WTO law, based on the assumption that the worst that could happen is to be challenged. Leading to a dispute at the DSB. The delay on compliance is observed in the sense that Members delay the compliance with a recommendation from the DSB as much as they can, within the rules of the system. And finally the non-compliance, "open and disguised" is used by authors to address the increasing number of decisions where WTO Members have openly decided not to comply and accept risk retaliation ${ }^{262}$.

The remark made by Coleman et.al addresses touches upon major concerns among WTO scholars and members. If members simply decide not to comply with a dispute settlement decision and pay the price to keep the breach of its multilateral obligations, there is hardly anything that can be done. Sanctions are weak -in fact they are not even called sanctions as indicated before -, and Members can opt to pay to maintain the inconsistent behavior.

More than anything, the "compliance option" shows how power oriented is the multilateral trade system, despite the fact that WTO is in essence a rule oriented Organization. If that is the case, low-power States are more likely to play a passive role while high-power States model the system as they wish ${ }^{263}$.

\footnotetext{
${ }^{260}$ Although Article 21.3 of the DSU establishes the possibility of granting a reasonable period of time for the violator to comply if it is impracticable to promptly comply, the DSU does not leave the opportunity open for an option to comply or not. Article 21.3, DSU states that "If it is impracticable to comply immediately with the recommendations and rulings, the Member concerned shall have a reasonable period of time in which to do so". Robert Hudec highlights that - and this was mentioned before in this research -, "despite the softer connotation of the word recommendation, the traditional understanding of the word recommendation in GATT/WTO jurisprudence has been that, when approved by the plenary body acting for the full membership, it is a legally binding order". Hudec, 2000, p. 10.

${ }^{261}$ Coleman; Horlick, 2007, p. 141.

${ }^{262}$ Id., p. 141-142.

${ }^{263}$ To read more on power orientation, see: Jackson, 1978 and; Dunne III, 2002.
} 
Although the DSU establishes mechanisms to induce compliance, and even though the WTO is famous among international organizations, because of its provisions that allow to certain extent, the punishment of the noncompliant State, the system has clear limits when confronted with the power of the big players ${ }^{264}$. From the reading of the DSU provisions, it is clear that the WTO did not intend to leave open an option not to comply with its decisions. Instead, the compliance is intended to be mandatory, as a security rule to guarantee that the system works effectively.

Notwithstanding, data and numerous papers have shown that the settlement of disputes at the WTO does not work in the way it should. It may be a little extreme to claim that Members comply with WTO decisions when and how they wish so - depending on their influence and participation in the multilateral trade -, but to a large extent, the facts seem to lead to this preliminary conclusion. And if that is true, it is also true that the asymmetry in the market size of the opponents in a dispute is also taken in consideration in the decision to comply or not.

Moreover, the political influence of the members has a great importance especially in the directions that are taken by members in the implementation phase of the dispute settlement. In fact, and as suggested before in this study, the retaliation procedure is considered to be more political than economic ${ }^{265}$. Indeed, all things considered it is right what is stated by Ezeani: "the fact is that the key to enforcement of dispute findings rests more on the strength of political persuasion on the country in violations to redress the harm its domestic measures have occasioned"266.

Therefore, it seems to be the case that both, economic and political asymmetries come to the playing field in the moment of implementation of DSB recommendations and rulings. Thus, as previously argued by Hudec, the threat of trade retaliation may influence political decision-making in the target $\operatorname{member}^{267}$.

Moreover, if political interests and future relations can be threatened by trade retaliation, the respondent member may also take into account its own reputation in the

\footnotetext{
264 This was said before, but in any moment the DSU mentions punishment or sanctioning in its text. The approach adopted by this study is that the retaliation available to members in the dispute settlement system is to induce compliance.

${ }^{265}$ In the conversation with Peter van den Bossche (Geneva, March 2011), he also suggested that retaliation and its developments is far more political than economic.

${ }^{266}$ Ezeani, 2010, p. 129.
} 
multilateral scenario, as suggested by general internal law bibliography. Whether reputation or the threat of losing market access is more or less important is hard to say and shall be analyzed in on a case-by-case basis in each specific dispute.

Following the stream adopted in this research endeavor, Princen states that compliance is encouraged to the extent that the position of domestic actors that favour compliance is strengthened in comparison to the political factors that favour noncompliance ${ }^{268}$. In being so, a dispute settlement system with more strength to enforce compliance or to sanction a violator may lead to a better behavior of States i.e. WTO Members.

\subsubsection{Economic Asymmetry and Compliance}

The approach adopted by the present study suggests that the economic asymmetry of WTO members has great importance in the implementation (or not) of DSB/Appellate Body recommendations and rulings. Nonetheless there is a different stream that follows the understanding that neither economic asymmetry nor any other type of differences among members influences the decision to comply with WTO law. The States comply (or not) regardless of the law or the threat imposed by others.

In that sense, Bush and Reinhardt state that "a rich complainant has no special advantages over a poor but equal-sized complainant in securing compliance from a defendant found in violation of WTO obligations" ${ }^{\prime 269}$. In the same vein, but with a different approach, Nottage argues that:

GATT and WTO dispute settlement practice demonstrates high rates of compliance with adverse dispute settlement rulings even when smaller and developing countries are complainants. This practice suggests that countries comply for a multitude of reasons of which the fear for retaliation is often not a necessary ingredient ${ }^{270}$.

\footnotetext{
${ }^{267}$ See Hudec, 2000 and; Charnovitz; Kearns, 2002.

268 Princen, 2004, p. 557.

${ }^{269}$ Busch; Reinhardt, 2003, p. 732.
} 
These authors suggest that there is no disincentive for compliance when a developing country i.e. a small economy is complaining against a powerful nation-State. Especially Nottage - by analyzing the high rates of compliance with DSB/Appellate Body recommendations -, defends the position that the decision to comply or not has nothing to do with the fact that a weak member is the complainant.

The author presents an interesting approach arguing that retaliation is hardly ever the main ingredient in the various reasons why a government decides to comply (or not) with a WTO dispute settlement ruling. Moreover, the author proposes that the capacity to threat with an effective retaliation is often an insignificant factor for government compliance regarding WTO issues ${ }^{271}$.

Therefore, Nottage assumes that the WTO system effectiveness is not undermined because of the asymmetries of WTO members and the lack of capacity of most developing members to impose a credible threat of retaliation. States comply or do not comply with WTO rulings because they want to keep the system functioning and, according to Nottage's understanding, that explains the high rates of compliance. Thus, developing countries "should not be overly dissuaded from using WTO dispute settlement to achieve their trade objectives due to a lack of retaliation capacity" ${ }^{272}$.

If Nottage is right, then the major driving force of compliance with WTO rulings is aligned with the care that States have with their own reputation in the international society, which was addressed in the first section of this chapter. With the aim to guarantee or at least prevent future decrease of negotiations in the international arena, States prefer to comply with the decisions of international organizations.

To some extent, this research agrees with Nottage's point of view. Of course States have concerns about future negotiations and partnerships, especially in the interdependent scenario that forms the current international society. Countries are increasing their partnership in many sectors of industries and trade. The flow of international investments and the transfer of technologies and knowledge are impressive. States need their international partners to improve their level of development.

\footnotetext{
${ }^{270}$ Nottage, 2010, p. 337.

${ }^{271}$ Id., p. 327.

${ }^{272}$ Id., p. 338. In the same line, Malacrida argues elsewhere that compliance with WTO rulings does not depend on the complainant. See Malacrida, 2008.
} 
That is all true. And it is definitely true that the States want to - in most of the situations - keep their good reputation. Nevertheless, the massive inequalities of the members of multilateral trade system are astounding. It is not possible to dismiss the fact that these massive political, economic and social inequalities are taken in consideration by the violator in the decision to comply.

The dispute settlement system of the WTO plays an important role in providing security and predictability to the multilateral trade exchanges. And the system is meant to work for all its Members. Even though statistics may indicate that the effectiveness of the system is not undermined by the member's economic asymmetries that could be involved in a dispute, this is no reason to ignore the fact that the inequalities and the possible amount of loss (or not) of market access have a decisive character in a decision to comply with WTO rulings. Reputation and the aim to keep a cooperative behavior are both important in the final position of a government.

Moreover, from comparing countries such as Antigua and the US confronting before the DSB, it is hardly impossible to avoid wondering that the insignificancy of Antigua's market, economy and poor political influence in the international sphere are great incentives for the US not to comply with the WTO rulings. Paying the price of noncompliance may probably be a better deal for the US government.

The arbitrator queried in the EC-Bananas III dispute on whether the inducement of compliance objective of the DSU "may ever be achieved where a great imbalance in the terms of trade volume and economic power exists between the complaining party seeking suspension and the other party"273.

Yet, and as Nottage himself states, "the arguments that the current WTO retaliation rules are skewed against developing countries have merit" ${ }^{274}$. Nonetheless, the arguments that even though the system is not shaped in a manner that could be more favorable to developing members is acceptable and its effectiveness to a large extent has to be recognized. The previously mentioned records of compliance, even when the complainant is a small economy comparing to the respondent, indicate that the system works. However, the DSU provisions deserve a careful review and claims to reform the DSU from developing countries shall be given attention, since they indicate where the system is defective and the

\footnotetext{
${ }^{273}$ WTO. WT/DS27 - Decision by the Arbitrators, 2000, para. 73.
} 
options to further develop the retaliation procedure are needed. The propositions of reform are going to be addressed in section 3.5.2 of this chapter.

\subsubsection{Compliance and State Responsibility at the WTO}

The discussion about compliance or noncompliance with DSB recommendations and rulings and, therefore, with WTO law leads to a subject that according to the analysis in this study cannot be forgotten, namely: the responsibility of States.

The WTO, as mentioned in the beginning of this study, refers to an international organization that was born and developed pursuant a treaty of International Public Law. The relations among WTO Members, the agreements signed, the negotiations agreed, the disputes settled, all that is secured by the general international law.

The set of rules that constitute the current regime of countermeasures under international law states that the State injured by a breach of an international obligation - i.e. a wrongful act - may only take countermeasures against the defaulting State in order to induce the violator to comply with its international obligations. That is the understanding of Article 49 (1) of the Draft Articles on Responsibility of States for International Wrongful Act: "An injured State may only take countermeasures against a State which is responsible for an internationally wrongful act in order to induce that State to comply with its obligations".

The regime of countermeasures refers to the implementation of State responsibility in general, being virtually applicable to all wrongful acts and breach of international obligations. In that sense, Reuter has stressed that "[...] international responsibility relates to the breach of obligations and its general principles are the same, whatever the source of the obligation" ${ }^{\text {275. }}$.

The WTO law is a lex specialis under general international economic law, which is a branch of general international public law. Thus, WTO law is under the scope of international public law and its rules on countermeasures are understood to be part of the broader definition of countermeasures in international law. The creation of the WTO law and

\footnotetext{
${ }^{274}$ Id., p.325.

${ }^{275}$ Reuter, 1989, p. 193.
} 
its lex specialis did not suppress its provisions on countermeasures from international public law $^{276}$.

Thus, if the provisions of countermeasures of the WTO are indeed provisions of international law, the provisions on State responsibility are also applicable to breach of trade obligations under the multilateral trade system. And in conclusion, if a WTO member fails to comply or simply does not comply with a WTO ruling proceeding from the DSB and/or the Appellate Body, the provisions on State responsibility seem to be logically applicable. Indeed, Perez-Aznar states that:

[...] trade countermeasures are one aspect of the game of unilateral acts of States that, before concretizing the GATT/WTO system, was an area regulated exclusively by general international law. The creation of the WTO implied a set of new rules concerning this type of countermeasures but this did not imply its total suppression from general international law ${ }^{277}$.

Most of DSU rules relating to the material aspects on countermeasures confirms and addresses the pre-existence of countermeasures rules of general international law. In the WTO law there are clear references to principles and provisions of international law, which corroborate this author's, understanding that rules on State responsibility for international wrongful acts are applicable to WTO members when there is notable insistence in noncompliance with DSB decisions.

\subsection{Cross-Retaliation: an attractive option for developing countries}

As previously noted, it is in the area of compliance and implementation that most worries of the WTO members are (or should be) focused on. The traditional retaliation is an instrument that in reality is only efficient for powerful nations. For instance, the US and the EC can take full advantage of a suspension of trade concessions, but that is not the case for most of the WTO members. As a way of solution, cross-retaliation is becoming a popular weapon among developing countries.

\footnotetext{
${ }^{276}$ See Perez-Aznar, 2005, p. 35-36.

${ }^{277}$ Id., p. 36.
} 
Initially, one should keep in mind that the often used terms retaliation and crossretaliation are not found in the text of the DSU. As aforementioned, the term retaliation refers to the suspension of trade concessions and obligations of the Article 22 of the DSU. On the other hand, the term cross-retaliation refers to the possibility of retaliating a respondent under a trade agreement different from the one that has been originally claimed. This possibility is open pursuant Article 22:3 (c) of the DSU.

Article 22:3 (a) states that the complainant should first seek suspension of trade concessions under the same sector as that in which the panel or Appellate Body has found a violation or other nullification or impairment. If that is not found effective or practicable, than two other options are available to the party:

(b) if that party considers that it is not practicable or effective to suspend concessions or other obligations with respect to the same sector(s), it may seek to suspend concessions or other obligations in other sectors under the same agreement;

(c) if that party considers that it is not practicable or effective to suspend concessions or other obligations with respect to other sectors under the same agreement, and that the circumstances are serious enough, it may seek to suspend concessions or other obligations under another covered agreement $(\ldots)^{278}$.

With the exception of larger economies in developing countries like Brazil, India and China, most of the developing countries have small economies incapable of producing any impact on the economies of developed countries. Since the former are more likely to have an insignificant market share than the latter, the threat of retaliatory measures by developing countries does not cause any tension in the economies of powerful WTO members.

It is not too farfetched to claim that the traditional retaliatory proceeding pursuant the DSU is counterproductive. Whether it is a small developing economy or a powerful one, the retaliatory system based on raising trade barriers by suspending concessions and other obligations deploys a negative way of solving disputes.

Abbott explains that the theory behind the suspension of concessions is that, by authorizing them, private operators in the country of the respondent will exercise their

${ }^{278}$ Article 22:3, DSU (emphasis added by the author). 
influence on the government to bring the trade inconsistent measures into conformity in order to avoid harm to themselves ${ }^{279}$.

That is why the complainant has to think very carefully in a suspension strategy and seek target goods or services in the respondent's domestic market which have strong political voice so as to maximize the pressure. At the same time the complaining must seek to target goods or services in areas that will not cause much harm to its own domestic market.

Certainly, for most of the developing countries, the economic damage perchance caused to manufactures, services providers and consumers from raising trade barriers by suspending concessions will overcome the economy harm intended to bite the respondent member. In fact, as Hudec suggests, raising trade barriers for manufactures may increase the costs of inputs that may raise the final price of products destined to the domestic or to the international market ${ }^{280}$. The domestic market loses.

Although the losses of a developed economy may not represent a big problem for the domestic economy, the situation is not the same for a developing economy which is struggling for a better position and a bigger market share with its partners.

The idea of the suspension of concessions is to induce compliance (regardless of whether they are effective in induce compliance or not). If that is so, inducing compliance by retaliatory measures may be very difficult where there exists a great imbalance in terms of trade volume and economic power of the members involved in the dispute. Indeed, especially regarding primary goods and investment goods the suspension of concessions is likely to be very counterproductive because of the increase of costs for manufactures and the consequent probable loss of competitiveness ${ }^{281}$.

Therefore, keeping in mind the idea of inducing compliance, cross-retaliation is referred to as an option for smaller developing countries to retaliate in a more effective way. For example, not paying patent royalties for a patent holder from the respondent member may, on the one hand, increase the welfare in the complainant market and on the other employ heavy political pressure in the violating country ${ }^{282}$.

\footnotetext{
${ }^{279}$ Abbott, 2009, p. 10.

280 Ibid.

${ }^{281}$ See Abbott, 2009.

${ }^{282}$ See Bown; Pauwelyn, 2010, p. 14.
} 
Normally retaliation will take place relating to the same sector and same agreement at issue in the dispute. Nevertheless, whenever a member considers that it is not effective or practicable to apply suspension of trade concessions under the same WTO agreement, the member can ask for cross-retaliation pursuant Article 22:3 (c).

By effective and according to the Oxford Dictionary it means "successful in producing a desired or intended result" ${ }^{283}$. The effectiveness should be understood as powerful in effect, achieving the result desired. On the other hand, practicable means "able to be done or put into practice successfully"284. It implies the verification of the practicability of the suspension of concessions in a determined sector in real practice, considering all the conditions of the complainant and the respondent's market.

The verified intentions of cross-retaliation normally include suspensions on trade concessions under the GATS or TRIPS, the two new value areas introduced as consequence of the Uruguay Round negotiations. As this research has its focus on cross-retaliation regarding intellectual property rights, cross-retaliation on services will appear in the discussion as a reflection of the main subject only.

Indeed, cross-retaliation under GATS does not seem as promising as crossretaliation under TRIPS Agreement obligations. Suspension on services has been authorized only one time - in the EC-Bananas case. One reason for that is the fact that developing countries are largely dependent upon service suppliers from developed countries.

On a study on cross-retaliation under GATS supported by the International Centre for Trade and Sustainable Development (ICTSD), Appleton affirms that cross-retaliation in services will not be sufficient to persuade a respondent to bring its inconsistent trade measure into conformity. The author believes that when developing members suspend GATS concessions and other obligations they will undoubtedly suffer. On the other hand, when the suspension of concessions is made under TRIPS, the developed world is more likely to suffer ${ }^{285}$.

Notice that cross-retaliation is applied in a MFN basis, which means it is directed only to the member losing the dispute. The major obstacles of cross-retaliation are technical

\footnotetext{
${ }^{283}$ Effective according to the Oxford Dictionary means "successful in producing a desired or intended result". repeated

${ }^{284}$ Ibid.

${ }^{285}$ See Appleton, 2009, p. 33-34.
} 
issues of implementation in the domestic market. Although this research will encompass the three cases in which cross-retaliation was approved, the mechanism was not put in practice till date. From the documents it is possible to imagine the technical challenges for the domestic market, but it is hard to estimate the real difficulties.

Also, cross-retaliation is a purely political mechanism of pressure to induce compliance. That is, indeed, another challenge for developing complainant members, as they have to fight against the heavy pressure of powerful private sectors. In the specific case of intellectual property (IP) rights, the IP-dependent industries can make a big noise in the media, for example, and accuse the complainant suspending countries of pirate violation international IP rights.

Article 22:3 (c) DSU also mentions that the circumstances should be serious enough to justify a cross-retaliation. The complainant must clarify to the WTO the reasons why a cross-retaliation is being asked showing the serious circumstances involved. For that matter, Article 22:3 (d) DSU specifies that the party shall take into account i) the trade in the sector or under the agreement under which the panel or Appellate Body has found a violation or other nullification or impairment, and the importance of such trade to that party" and ii) "the broader economic elements related to the nullification or impairment and the broader economic consequences of the suspension of concessions or other obligations".

Yet, Article 22:4 of the DSU reinforces the necessity of equivalence of the level of retaliation, which was previously mentioned in this research endeavor, in the section dedicated to the suspension of concessions. This could be a terrain of quicksand to the arbitrators.

As there is no definition of what an equivalent measure shall take into account, arbitrators should make their own choices on how to access proportionality ${ }^{286}$. In any case, the first step to determine equivalence is to look at and calculate the harm that will be caused by cross-retaliation taking into account the level of nullification and impairment considered in the dispute, which is a very complex process as will be shown in the analysis of US-Gambling case, in the next chapter.

Cross-retaliation is a proceeding positioned as an exception, a secondary option if traditional retaliation is proved by the complaining member to be impracticable or ineffective

\footnotetext{
${ }^{286}$ See Basheer, 2009, p. 16-17.
} 
in a certain dispute. Notwithstanding, in what concerns developing countries, cross-retaliation has been presented as a more effective remedy. Especially cross-retaliation under TRIPS is likely to impose the pressure in the right place, where it may cause more harm to the IPdependent industries from rich developed countries.

\subsubsection{Cross-Retaliation as a development vehicle to WTO members}

As state by the WTO Director-General Pascal Lamy, there are crucial links between trade and development ${ }^{287}$. That explains why the WTO has been working hard in the Development Agenda of 2001. The main purpose of the Agenda is to address the needs of developing countries - which totalize two thirds of the WTO membership. Indeed, the current Doha Round was launched specifically to work with development issues in connection with multilateral trade issues under the WTO.

Regarding the dispute settlement system, according to the Doha Ministerial Declaration, members agreed to negotiate on improvement and clarifications of the DSU. In the light of the Development Agenda, the negotiations should be grounded on the work done so far and any additional proposals by Members are welcome.

According to the preamble of the Marrakesh Agreement, the relations under the WTO shall basically:

\footnotetext{
- $\quad$ be conducted with a view to raising standards of living for its members;

ensure full employment as well as a great and steadily growing volume of income and demand;

allow the optimal use of the world's resources in accordance with the objective of sustainable development and;
}

\footnotetext{
${ }^{287}$ Presentation of Secretariat note on Development Aspects of the Doha Round to the WTO's Committee on Trade and Development on 28 November 2005. Available online at: $<$ http://www.wto.org/english/news_e/news05_e/stat_lamy_28nov05_e.htm>.
} 
seek to protect and preserve the environment as well as enhance the means for doing so in a manner consistent with their respective needs and concerns at different levels of economic development ${ }^{288}$.

It is remarkable that the establishment of the WTO has contributed significantly to global economic growth, to overall development and the increase of employment since its creation. Unquestionably international trade can play a major role in the promotion of economic development. All members shall benefit from the opportunities that come along with trade liberalization and from join welfare gains generated by the multilateral trading system.

In what concerns the mechanism of cross-retaliation, it is accepted that suspending concessions and other obligations on TRIPS Agreement shall benefit a certain level of development and increase of social welfare. For instance, suspending pharmaceutical patents can allow the production of generic medicines in a considerable lower price while a suspension of copyrights could allow free reproduction of DVDs. Also, the cross-retaliation in TRIPS, if well planned and executed, can contribute to innovation increase in the suspending country, by the display of information that would therefore be copied to the benefit of country's industries.

The WTO has the commitment of deploying positive efforts to ensure that developing members participate in the growth of world trade securing and addressing their needs of economic development. That is translated into enhanced market access, more balanced rules and sustainably financed capacity-building programmes. These elements shall be continuously promoted following the increase of world exchanges.

\subsubsection{Feasibility of proposals to reform the DSU on behalf of developing countries}

Stimulated by the discussions launched in the Doha Development Round in 2001, several developing countries started working on propositions with suggestions to the improvement and or amendment of the DSU text. The most famous proposal is the one

\footnotetext{
${ }^{288}$ Preamble of the Marrakesh Agreement. Available online at: < http://www.wto.org/english/docs_e/legal_e/04wto_e.htm>.
} 
delivered by Mexico, which focuses mostly on the problem of retaliation as being only a prospective remedy.

As previously addressed in section 3.3.1, in actual practice and following the current provisions of the DSU, members only get compensation or exercise their right to suspend concessions prospectively. This situation can seriously affect trade in many cases. WTO litigation takes long - usually more than one year -, and during the period there is no possibility for member States or private sectors to seek compliance or remedies ${ }^{289}$.

In that regard, Mexico submitted a proposal on October 31, 2002 - TN/DS/W/23 with some interesting claims. First, Mexico suggested the introduction of mechanisms within the system of dispute settlement, at an early stage of the panel, allowing the calculation of the level of impairment or nullification suffered by the complaining Member ${ }^{290}$.

Currently, the DSU system makes the decision to judge the level of nullification or impairment after the reasonable period for the implementation of the decision expires, and in accordance with Article 22.6 of the DSU, presumably after termination of all procedures in Article 21.5.

In the view of Mexico, this action would create incentives for prompt compliance of the decision or recommendation, to promote and facilitate the negotiations, as members would be aware of the amount of nullification or losses considered, reducing the time during which the measure declared inconsistent remains without consequences.

Moreover, in an attempt to discourage members to keep up with measures declared inconsistent with the covered agreements, Mexico proposed the possible retroactive determination of damages suffered by the complaining Member.

The advantages shown by Mexico in this regard would be: (i) a more equitable distribution of benefits, or to ensure that the balance of rights and concessions obtained in the Uruguay Round were fully respected -since the claimant would be entitled to recover compensation and negotiate all the losses that were incurred by the measure declared inconsistent, or to suspend benefits in an amount equal to such losses; (ii) to gain time, as the

\footnotetext{
${ }^{289}$ See Plasai, 2007, p. 6. The author also addresses the exception of Article 4.6 of the Agreement on Subsidies and Countervailing Measures. The Article indicates that when the measure at issue is found to be a prohibited subsidy, the panel must recommend that the subsidizing member withdraws the subsidy without delay. Ibid.

${ }^{290}$ WTO, TN/DS/W/23.
} 
defending member would not have incentives to artificially delay the process and (iii) to facilitate the negotiations by eliminating the incentives to prolong the proceedings.

Their worries are reflected not only in documents and proposals by Members, but also in several working papers and books as shown during this research endeavor. For example, parallel to the proposal made by Mexico to the reform of the DSU, the African group corroborates the position of Mexico.

The countries agree with a retroactivity effect of retaliation, which should start to be accounted for from the date of imposition of the violating measure regarding the calculation of loss or damage caused by the measure declared inconsistent. The countries also suggest a monetary compensation especially to developing countries affected by illegal measures $^{291}$.

On the other hand, considering the issue of countermeasures, Ecuador ${ }^{292}$ and other the Least Developed Countries ${ }^{293}$ proposed the possibility of monetary compensation to developing countries for an unlimited period, if the responding party does not comply with the decision or recommendation within the reasonable period of time under the DSU. This proposal is quite interesting in the sense that the developed countries would be pressured to implement concrete decisions, and thus increase its power to pressure on the system.

The African Group, Ecuador and the Least Developed Countries, along with Kenya $^{294}$, Cuba, Honduras and other Members ${ }^{295}$ made the suggestion of collective retaliation. That proposal faced strong resistance from developed countries, and referred to the possibility to suspend concessions for more than one Member with the aim of ensuring the effectiveness of countermeasures. The proposal specifically addresses the disputes in which a developing country is allowed to retaliate against a developed one.

As it is, a similar proposal had already been made in 1965, during GATT. The justification of the proposal is that small economies can form groups with similar or converging interests to improve their bargaining power during negotiations ${ }^{296}$.

\footnotetext{
${ }^{291} \mathrm{WTO}, \mathrm{TN} / \mathrm{DS} / \mathrm{W} / 15$.

${ }^{292} \mathrm{WTO}, \mathrm{TN} / \mathrm{DS} / \mathrm{W} / 9$.

${ }^{293} \mathrm{WTO}, \mathrm{TN} / \mathrm{DS} / \mathrm{W} / 33$.

${ }^{294} \mathrm{WTO}, \mathrm{TN} / \mathrm{DS} / \mathrm{W} / 42$.

${ }^{295}$ WTO, TN/DS/W/19.

${ }^{296}$ See Hudec, 2002, p. 86.
} 
Finally, another proposal to give greater effectiveness to the system during the implementation phase and that could be used only when the plaintiff sued by a developing country and a developed country, is cross-retaliation, supported by Cuba, Honduras, India and some other members ${ }^{297}$. Note that even though cross-retaliation is accepted by the WTO when traditional retaliation in not practicable of effective, there is no specific provision in the DSU in this regard.

Tackling retaliation and WTO remedy issues as a whole, Davey argues that there are several practical changes in this regard that offer hope for the improvement of WTO implementation system. According to the author, the WTO should incorporate:

(i) The possibility of substituting fines or damages as a remedy in lieu of suspension of concessions;

(ii) Some degree of retroactivity, so as to help encourage compliance within the reasonable period of time and;

(iii) Some adjustment mechanism to increase the level of sanctions over time, so as to preclude non-compliance from becoming an acceptable status quo position ${ }^{298}$.

Regarding the possibility of substituting fines or damages, it seems that it would be an interesting and feasible option. Most of all, the idea of this change is to tie the amount of fines or damages to the size of the member's economy - or, put differently, to provide a sliding scale to diminish/minimize discrimination against small economies. Unquestionably, the system would have to be designed, according to Davey, in a way to avoid the possibility that powerful developed countries could effectively buy their way out of obligations within the multilateral trading system ${ }^{299}$.

This idea is also supported by Matsuchita et.al., whom support that fines, in special, should play a center role. The authors understand that a system of fines could represent more incentive to induce compensation since the fines would increase over time and be based upon the size of the member's economy ${ }^{300}$.

\footnotetext{
${ }^{297}$ WTO, TN/DS/W/47.

${ }^{298}$ Davey, 2009, p. 125-126.

${ }^{299}$ Id., p. 126.

${ }^{300}$ Matsuchita; Mavroidis; Schoenbaum, 2003, p. 94.
} 
The idea of introducing fines and/or damages to the dispute settlement system also encompasses the aforementioned suggestion of monetary compensation. Although it could be considered as a discrimination against developed members, the suggestion is that developing countries and small economies should be given the choice between suspension of concessions and receipt of a periodic monetary payment ${ }^{301}$.

The system of prospective measures definitely does not help or encourage prompt compliance. That is the most critical flaw addressed by the Mexico proposal. Therefore, in order to minimize the problem and so as to stimulate prompt compliance with DSB/Appellate Body decisions, any remedy considered by the DSU should be calculated from the (i) date of establishment of the panel; (ii) date of adoption of the relevant report or, (iii) earlier date (e.g. date of the facts, if it is possible to define) ${ }^{302}$.

The third suggestion addressed by Davey, considering the increase sanctions over time, also appears to be a feasible solution for improving the implementation system. The procedure of increasing sanctions would probably help to avoid the wrong perception that the payment of fines and/or damages is no more than an alternative to compliance ${ }^{303}$.

Indeed, Matsuchita et.al. highlight the fact that compensation should be mandatory rather than voluntary. In that sense the authors argue that even though compensation as a practical matter cannot be forced - once it is conceded by the losing/respondent State -, it would probably become much more attractive to violators if other available sanctions are put into play ${ }^{304}$.

Moreover, the same authors make a controversial but probably effective suggestion, i.e., to suspend a recalcitrant member's right to participate into the WTO system. The idea is that the suspension could be gradual: (i) initially the suspension could take the form of denial of rights on certain committees and working parties; (ii) then it leads to greater denial of rights, it could lead to the suspension of the right to participate in WTO council meeting or to use the dispute settlement system ${ }^{305}$.

\footnotetext{
${ }^{301}$ See Davey, 2009, p. 126.

302 Ibid.

${ }^{303}$ Ibid.

${ }^{304}$ Matsuchita; Mavroidis; Schoenbaum, 2003, p. 94.

${ }^{305}$ Ibid.
} 
From the discussion above, it is most likely that the introduction of retrospective remedies and the improvement and increase of DSU sanctions over time address the problems of timeliness and quality of implementation of the DSB/Appellate Body recommendations. The cost of noncompliance would increase.

As stated in the very beginning of the present study, the WTO implementation phase is the most problematic part of the dispute settlement system. According to Article 3.3 of the DSU, the purpose of the dispute settlement is to maintain a proper balance between the rights and obligations of WTO members ${ }^{306}$. However, the mechanism of retaliation appears to allow member's behaviors that go against that purpose, since it allows the countries to buy out of their obligations by providing poor compensation or enduring the suspension of concessions and other obligations pursuant the DSU.

\subsection{Concluding Remarks}

This chapter aim to give an overview of the WTO dispute settlement system and the problems related to it relevant to the present study. Despite having constructed a legalized and quite successful framework to settle its disputes, the WTO has been facing problems, especially concerning compliance and implementation of its decisions and rulings.

The problems involve not only the discussion of the binding effect of DSB recommendations and rulings but also, and perhaps more importantly, the economic asymmetry of WTO members. Asymmetries that can be translated into huge differences regarding GDP, market share, technological standards, innovations and political power play a key role considering dispute settlement issues.

Problems relating to financial resources to improve the legal capacity of most developing countries to litigate are given especial attention in the chapter. Nevertheless, the worries are focused on the implementation phase of the DSU, notably when the dispute in the field has a developing country in the complainant seat and a developed wealthy economy in the respondent one. Although the WTO could be proud of the high level of compliance with

\footnotetext{
306 Article 3.3, DSU: "The prompt settlement of situations in which a Member considers that any benefits accruing to it directly or indirectly under the covered agreements are being impaired by measures taken by another Member is essential to the effective functioning of the WTO and the maintenance of a proper balance between the rights and obligations of Members".
} 
its disputes, there are imperfections in the system, which has the power to cause huge losses of welfare to members.

Also, the chapter intended to encompass the elements that incentive or disincentive compliance at the WTO. Implicitly, the chapter intended to tackle the celebrated high rate of compliance in the WTO and verify what underlies this rate and the reality of the facts.

It dealt with definitions of compliance in general international law. As repeatedly mentioned in this dissertation, the multilateral trade system functions under international public law principles, and therefore there remains a strong connection between what happens in the WTO and the interpretations deriving from international law.

Moreover, the chapter addressed the compliance at the WTO and whether compliance is an option available to members or whether it is an obligation that should be observed. Compliance with DSB recommendations is high. Nonetheless, there are intrinsic elements and situations that include a number of delayed compliance and non-fully compliance in that high rate. Still, close attention to shall be paid as every instance of noncompliance with WTO decisions is very problematic.

Cross-retaliation seems to be an effective solution to some of the imperfections in the implementation system. Even though the approved cross-retaliation proceedings were not put into practice, and even though they are still considered secondary options to retaliate, cross-retaliation proceedings have been observed by WTO scholars and practitioners as effective tools for developing countries to induce compliance.

Especially suspension on IP rights seems to be extremely interesting. It affects sensible and very powerful sectors of industries IP-dependent, mostly concentrated in developed countries. Whether this option of suspending IP rights is available and feasible to all developing countries it going to be further discussed in the next chapter. 


\section{INTELLECTUAL PROPERTY RIGHTS: cross-retaliation in TRIPS}

This chapter addresses the intellectual property rights and its suggested importance to the cross-retaliation mechanism.

So as to discuss suspension on TRIPS obligations and its effectiveness as retaliatory weapon against developed countries, it is fundamental to understand and briefly analyze the intellectual property rights in general and their scope, in particular.

Moreover, it is indispensable to study how the suspension of these rights works in terms of level of retaliation, proportionality and inconsistency issues addressed in the default dispute.

Three cases are analyzed in detail for the purpose of this study, namely: the ECBananas III, the US-Gambling and the US-Cotton. The rationale for selecting these cases is justified in that they are the only three disputes in the WTO where a cross-retaliation in IP rights was requested and approved. The specificities of the cases may shed light on the functioning and effectiveness of the suspension of concessions under TRIPS and whether this option is a solution to implementation problems in the WTO available to all developing members.

The first section of the present study encompasses general issues of the TRIPS agreement. It will offer an overview on IP rights, discussing the typology and utility of each type of intellectual property right. This is important as it may select, on a preliminary basis, which types of rights might be available to promote a successful cross-retaliation.

It is worth stressing that there is no intention to undergo a deep analysis regarding each intellectual property right. Instead, this chapter aims at providing a useful background and framework against which the research findings may be contrasted.

The second section of this chapter elaborates on TRIPS as part of the WTO framework. It is intended to evaluate whether the suspension on TRIPS obligations is a feasible option. The calculation of the level of retaliation and the attention to the proportionality of the harm caused by the inconsistent measure will also be addressed in the second section. 
The third section addresses the challenges and the costs of a retaliation procedure and the scope of cross-retaliation. Although cross-retaliation on intellectual property rights at the same time offer a more credible threat considering retaliation and raises opportunities for increasing the social welfare for the domestic market, it brings together some challenges and (high) costs for the suspending member.

The fourth section discusses implementation issues related to suspension of concessions under TRIPS, focusing on economic feasibility and political issues. Then the fifth section complements the previous section, analyzing whether suspension of concessions under TRIPS addresses the basic issue of noncompliance at the WTO.

Finally, the sixth section presents a review and discusses the three cases selected in context of TRIPS cross-retaliation. Although none of the cross-retaliation measures were put in practice, the cases selected provide detailed documents and represent a rich source of information for the upcoming conclusions.

\subsection{General Issues of the TRIPS Agreement and IP framework}

Intellectual property is a legal construct and as such refers to the protection of a creation of the mind. The types of creation can be allocated in different groups for which a different set of exclusive rights are recognized. Certainly the term property is used to imply the existence of rights related to intellectual products.

According to the World Intellectual Property Organization (WIPO), intellectual property refers to inventions, literary and artistic works, as well as symbols, names, images, and designs used in commerce. Thus, in the broad sense, intellectual property is related to the protection of information, protection of intangibles assets.

What makes an intellectual product somebody's property in legal terms is the fact that no one can take or use it without the right holder permission. Indeed, the protection of intellectual property "is concerned with identifying and policing permissible and impermissible dealings with intellectual products, usually by reference to the consent of the right holder, at list in the first instance" ${ }^{307}$.

\footnotetext{
${ }^{307}$ Laurie; MacQueen; Waelde, 2008, p. 7.
} 
Thus, intellectual property rights are legal rights that have the intention of safeguarding producers and creators of intellectual goods and services by granting them rights - with limited time - to control and profit from the use of those intellectual assets by other parties.

By protecting intellectual property, the compromised interests of the private creator or producer are being safeguarded and, at the same time, others are being excluded from an unauthorized use and profit. Laurie et. al. divide the interests compromised by the protection of intellectual property in three categories: moral interests, social interests and economic interests ${ }^{308}$. In short, moral interests refer to personal interests of the creator who deployed labor, time and expenditure efforts in the intellectual product. Social interests are somewhat like a puzzle, since intellectual proportion protection can yield considerable social benefits, but also become a problem if protected too strongly. For instance, if a pharmaceutical company is given to a creator - with too much market control, it may interfere in the health competition of the market, which will, consequently, operate to the detriment of consumers' welfare. Finally, the economic interests involved are not only the ones of the creator, but also the interests of competitors and customers. With the introduction of product protected by intellectual property, a monopoly ${ }^{309}$ is introduced and the overall balance of the market in that sector is affected, perhaps giving rise to a number of disputes in the affected areas.

Concerning economic interests, it is important to bear in mind that every intellectual property right distorts competition and consequently distorts the market ${ }^{310}$. By granting a legal right upon an intellectual creation, a monopoly is created. Since it generates detriment to free competition, the justification relies on the positive purpose of the intellectual property rights.

\footnotetext{
${ }^{308}$ Id., p. 8-9.

${ }^{309}$ Monopoly is characterized by a lack of economic competition to produce a good or a service and it exists when a specific person or enterprise is the only supplier of a particular commodity. For more information see Friedman, 2002

${ }^{310}$ For more information concerning competition law concerning intellectual property rights see Sanders, 1997.
} 
As it is, intellectual property rights support and promote private interests at the same time as they incentive innovation by rewarding creators (see figure below) ${ }^{311}$. Also, IP rights contribute to the sum total of human knowledge.
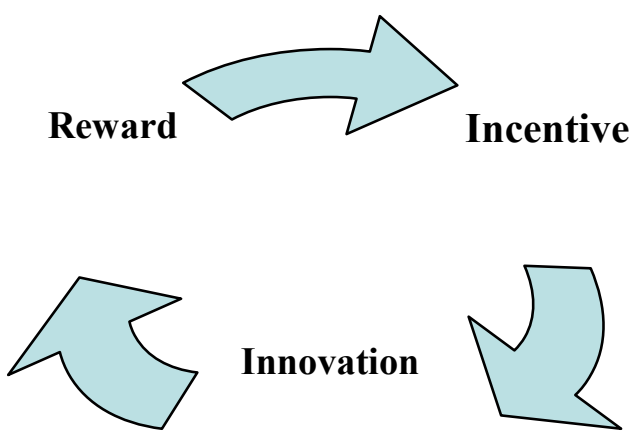

Figure 1. Source: Laurie, MacQueen, Waelde, 2008, p. 11.

Reward and incentive can be understood as two symbiotic elements, since a reward can serve as an incentive and an incentive can be a reward. Regarding the intellectual property system, both elements are the core of the law and economics approach ${ }^{312}$.

According to the WIPO, there are several compelling reasons to promote and protect intellectual property. First, the WIPO defends that the progress of the well-being of humanity relies on its capacity for new creations and productions in the areas of technology and culture. Second, in protecting the new creations, the intellectual property system is encouraging the expenditure of new resources, which in the end will lead to more innovation. Third, "the promotion and protection of intellectual property spurs economic growth, creates new jobs and industries, and enhances the quality and enjoyment of life" ${ }^{{ }^{13}}$.

Therefore, it is common sense that intellectual property rights are a powerful tool for the economic development and the promotion of social welfare if an efficient, equitable and fair intellectual property system is established. In an ideal situation, intellectual property law may balance the interests of the inventor/innovator and the public interests.

As stated by Sanders, the concerns for public interests and the development dimension are certainly key features in the search for balance of intellectual property rights

\footnotetext{
${ }^{311}$ It refers to rewarding the rewarding theory. To learn more about rewarding intellectual property theories, see Menell, 1999.

312 See Landes and Posner, 2003.

313 World Intellectual Property Organization, What is Intellectual Property? Published online at: $<$ http://www.wipo.int/freepublications/en/intproperty/450/wipo_pub_450.pdf $>$. Last accessed on 30 Jul. 2011.
} 
and the public domain ${ }^{314}$. In fact, there is a major trend studying the protection of intellectual property and its role as development promoter.

Notably in developed nations the intellectual property system has presented great achievements. Among the reasons for the favorable results for developed economies, Correa points out some of them, which are relevant to this research endeavor ${ }^{315}$ :

Technology has become a factor of growing importance in the
international competition scenario. Not without reason, since the
expenditures of industrialized countries have been steadily
increasing since the 1970 's, with great participation in private
sectors in research and development (R\&D);
The elimination or reduction of trade barriers in developing
countries facilitated the exports from the developed world to the
developing economies. Together, it brought an increase in the
pressure of multinational companies to get unrestricted access to
those markets that made pressure also to freely exploit patents
locally.

Still, according to Correa, the legal framework that emerged regarding intellectual property rights universalizes standards of protection that are very suitable to developed economies. It is in the developed world where IP dependent industries are located, as it is in the wealthy countries where there is enough money to invest in research and development to support and provide incentive for the creation of intellectual assets.

Normally the intellectual property rights are divided into two categories: (i) the group of industrial property, which includes patents for inventions, trademarks, industrial designs and geographical indications and; (ii) the group of copyright, which includes literary works - novels, poems, films, music - , artistic works, such as paintings, drawings, photographs and, a third category, the architectural designs.

\footnotetext{
${ }^{314}$ Sanders, 2005 , p. 5.

${ }^{315}$ Correa, 2000, p. 3-4.
} 
Since the intention of this research is not to exhaust all the intellectual property rights, the most important types are going to be briefly analyzed in the next section. Nevertheless, the rights selected to be described and explained will be discussed in the research paper because of their importance to the conclusions of this chapter concerning the utility of cross-retaliation for developing countries.

A final comment is due before moving on with the intellectual property framework and concerns the characteristic of intellectual property to be inexhaustible. As an intangible subject matter, more than one person can possess or use the same intellectual asset without depriving any other of the same enjoyment. This makes intellectual property an inexhaustible resource ${ }^{316}$.

\section{- WIPO}

The World Intellectual Property Organization is a specialized agency within the system of the United Nations (UN). It was established by the WIPO Convention in 1967 with the intention to arrange a better understanding and cooperation among States and in order to encourage creative activity and promote protection of intellectual property through the world $^{317}$.

The last century was marked by an impressive increase in the adoption of conventions on IP. Indeed, intangible assets are the jewelry of the post-industrial era. The WIPO has an important role, as it is responsible for the administration of many of the conventions adopted (currently WIPO administers 24 treaties).

In fact, WIPO also administers two of the most important intellectual property conventions which will be given some attention in the present study - the Paris Convention for Protection of Industrial Property and the Berne Convention for the Protection of Literary and Artistic Works.

In general term we can say that among the main objectives of WIPO are the harmonization of national intellectual property legislation, the provision of services for

\footnotetext{
${ }^{316}$ See Dratler, 1991, p. 1-3.

317 The Convention establishing the World Intellectual Property Organization is published online at: $<$ http://www.wipo.int/export/sites/www/treaties/en/convention/pdf/trtdocs_wo029.pdf $>$.
} 
international applications for industrial property and legal and technical assistance to developing countries as well as the facilitation of the resolution of private intellectual property disputes through its Arbitration and Mediation Center $^{318}$.

It is worth mentioning that WIPO has a Development Agenda that aims to undermine the existing gap regarding wealthy and poor nations $\mathrm{s}^{319}$. The Organization currently has 184 members, representing considerable differences in what concerns intellectual property protection and its use.

The Development Agenda for WIPO was adopted in October 2007, and among its 45 recommendations the following are highlighted: (i) technical assistance and capacity building shall be develop-oriented taking into account the priorities and the special needs of developing countries, especially least developed countries; (ii) assistance to member States "to strengthen national capacity for protection of domestic creations, innovations and inventions and to support development of national scientific and technological infrastructure"; (iii) encouragement of "member States, especially developed countries, to urge their research and scientific institutions to enhance cooperation and exchange with research and development institutions in developing countries, especially LDCs" and; (iv) assistance to member States "to develop and improve national intellectual property institutional capacity through further development of infrastructure and other facilities with a view to making national intellectual property institutions more efficient and promote fair balance between intellectual property protection and the public interest" ${ }^{\prime 320}$.

The WIPO and the WTO work in close collaboration with each other. Both Organizations signed an Agreement for mutual supportive relationship between them, so as to establish appropriate arrangements for cooperation ${ }^{321}$.

Therefore, under the Agreement, WIPO provides technical assistance to the developing country members of the WTO. By offering expertise in the area of intellectual property law, WIPO closely monitors and works to ensure a successful implementation of the TRIPS Agreement.

\footnotetext{
${ }^{318}$ Note that WIPO has a dispute resolution system to settle disputes regarding only domain names.

319 The 45 Recommendations for the Development Agenda are published online at: <http://www.wipo.int/ipdevelopment/en/agenda/recommendations.html>.

${ }^{320}$ Ibid.

${ }^{321}$ Agreement between the World Intellectual Property Organization and the World Trade Organization available at: < http://www.wipo.int/treaties/en/agreement/trtdocs_wo030.html>.
} 
- $\quad$ Paris Convention

Signed in 1883, the Paris Convention was the first endeavor to multilaterally protect industrial property and it is still the most important convention on the subject ${ }^{322}$. That is so true that until very recently all the agreements related to industrial property were written in French.

The Convention provides minimum protection standards for industrial intellectual property rights. According to Article 1.2, the Convention protects patents, trademarks, trade names, industrial designs, appellations of origin, and utility models.

Article 2 defines one of the key principles of the convention-also present in the GATT 1947-, the national treatment. Guided by this principle, discrimination of nationals of Member states to the Conventions regarding the protection of industrial property offered domestically is not allowed ${ }^{323}$.

By receiving a national treatment, foreigners were provided with a protection with domestic standard without prejudice to each nation's sovereign right to determine the content of law ${ }^{324}$. The great benefit is that the foreign right-holder will always be as protected as the national right-holder.

The other key provision of the agreement is the right of priority, with especial importance to the rights regarding patents. Article 4.1 of the Convention states that:

Any person who has duly filed an application for a patent, or for the registration of a utility model, or of an industrial design, or of a trademark, in one of the countries of the Union, or his successor in title, shall enjoy, for the

\footnotetext{
${ }^{322}$ In fact, the motivation for the creation of a system of protection for industrial property came when in 1873 foreign exhibitors refused to attend the International Exhibition of Inventions in Vienna as they feared that their inventions or ideas would be copied. Then, the International Congress on Industrial Property of 1878 established a framework for industrial property in response to the pleas of exhibitors. The result is the Paris Convention in 1883.

${ }^{323}$ Article 2.1 of the Paris Convention states that: "Nationals of any country of the Union shall, as regards the protection of industrial property, enjoy in all the other countries of the Union the advantages that their respective laws now grant, or may hereafter grant, to nationals; all without prejudice to the rights specially provided for by this Convention. Consequently, they shall have the same protection as the latter, and the same legal remedy against any infringement of their rights, provided that the conditions and formalities imposed upon nationals are complied with." Paris Convention is available online at: < http://www.wipo.int/treaties/en/ip/paris/trtdocs_wo020.html\#P77_5133>.

${ }^{324}$ See Claessens, 2009, p. 24-26.
} 
purpose of filing in the other countries, a right of priority during the periods hereinafter fixed ${ }^{325}$.

The right of priority status is attributed when corresponding applications whether related to patens, designs or trademarks - have already been filled in another member country convention within the preceding six months. What the system does is to give some time for the registrant to file multiple applications simultaneously in other member countries of the Paris Convention.

The Paris Convention together with the Berne Convention that will be addressed in the next sections, controlled the intellectual property scenario for almost a century.

\section{- Berne Convention}

Following the flow concerning the protection of intellectual property, the Berne Convention was signed three years after the Paris Convention, in 1886. The Berne Convention was adopted with the aim of protecting, "in as effective and uniform a manner as possible, the rights of authors in their literary and artistic works" ${ }^{326}$.

The Berne Convention constitutes a union for the protection of rights of authors in the field of literary and artistic works. It is the oldest international treaty concerned with copyrights.

As the Paris Convention, the Berne treaty also has the national treatment as one of the corner stones of the system of protection established by it, so that: "Authors shall enjoy, in respect of works for which they are protected under this Convention, in countries of the Union other than the country of origin, the rights which their respective laws do now or may hereafter grant to their nationals, as well as the rights specially granted by this Convention. ${ }^{327}$. Together with the national treatment, the Berne Convention establishes two other especial principles.

\footnotetext{
${ }^{325}$ Article 4.1, Paris Convention.

326 The Berne Convention for the Protection of Literary and Artistic Works is available online at: < http://www.wipo.int/treaties/en/ip/berne/trtdocs_wo001.html>.

${ }^{327}$ Article 5.1, of the Berne Convention: .
} 
The Convention grants what it known as independence of protection, according to which the rights granted under this Convention shall not be subject to any formality for their enjoyment and exercise. That means that the enjoyment and exercise of the rights shall be independent of the existence of protection in the country of origin of the work ${ }^{328}$.

A third singular principle brought by the Berne Convention is the automatic protection $^{329}$. According to this principle, protection to authors' right is granted automatically and it is not subject to registration or any similar procedure. The first publication shall be automatically recognized by all members of the Convention, meaning that national treatment shall not be dependent on any formality.

In the explanation regarding the intellectual property rights below, other conventions on intellectual property protection will be addressed. Nevertheless, only the Paris and the Berne Conventions were contemplated more prominently due to their importance in launching the process of building a multilateral intellectual property protection system.

\subsubsection{The TRIPS Agreement}

The Agreement on Trade-Related Aspects on Intellectual Property Rights is the most comprehensive agreement on IP, due to its coverage. Daniel Gervais refers to the agreement as "the most significant milestone in the development of intellectual property in the twentieth century" ${ }^{330}$. As an integrative instrument of the preceding existing conventions on IP rights, the agreement establishes minimum standards of intellectual property protection on:

Copyright and related right;
Trademarks;
Geographical Indications;
Industrial Designs;
Patens;
Integrated Circuits and;
Undisclosed Information (trade secrets).

\footnotetext{
${ }^{328}$ Article 5.2, Berne Convention.

${ }^{329}$ Article 5.1, Berne Convention.

${ }^{330}$ Gervais, 2003, p. 3. See also UNCTAD, 2003.
} 
The TRIPS Agreement was brought to the table of negotiations during the Uruguay Round by the industrialized nations; to a great extent led by the US. The objective was to universalize standards on intellectual property rights protection, already incorporated in the legislation of industrialized countries, since at that moment they had acquired a high level of technological and industrial capacity.

The argument of developed countries was that the traditional international legal framework concerning intellectual property rights (IPRs) was not properly adjusted to the changing needs of the intellectual property community. Also, industrialized countries argued that technological developments such as the advance of the information society facilitated and cooperated with the rapid copying and dissemination of material around the world, which demanded and required new forms of IPR protection ${ }^{331}$.

The basic proposal from the part of developed countries was that they would liberalize trade in goods but in return all the countries had to recognize basic standards on intellectual property protection (including the Paris and Berne Convention, and further conventions on IP).

Correa states that developing countries negotiated increased standards of protection of intellectual property rights against their will ${ }^{332}$. They acquiesced in making important concessions in terms of reforms of their intellectual property legislation, encouraged by the inclusion of policies to stimulate technology transfer, access to new technologies and pharmaceuticals and market access to their products. Notwithstanding, Correa points out that the developing countries did not obtain any compensating concession from industrialized countries ${ }^{333}$.

Also note that since GATT and until today most developing countries - due to their limited resources for investments in research and development (R\&D) and their lack of technological capacity - can only profit (to a limited extent) so much from an extensive intellectual property framework.

Even though the preamble of the TRIPS Agreement states that it was established with the desire to reduce distortions on trade and impediments to it, the one-fits-all model of

\footnotetext{
331 See Claessens, 2009, p. 45. The author also points out that the attempts to update the Paris and Berne Conventions and to improved enforcement mechanisms had failed over the years. Ibid.

332 Correa, 2000, p. 3

333 Ibid.
} 
the agreement makes the situation considerably difficult for developing countries and LDCs. Moreover, the preamble highlights the need to promote effective and adequate protection of intellectual property rights and the necessity to ensure that measures and procedures to enforce IPRs do not become barriers to legitimate trade ${ }^{334}$. Although the standards of protection may not establish barriers to trade, they surely contribute to the gap between develop and developing countries, as the latter do not have the same level of technological advance, knowledge and economic conditions to invest in their own intellectual wealth.

The standards of protection set forth in the TRIPS Agreement relate both to the availability of rights as well as to their enforcement ${ }^{335}$. That means that WTO members cannot establish levels of intellectual property protection lower than the one provide by the TRIPS Agreement concerning the IPRs coverage.

WTO members were obliged to implement "baseline standards and minimum enforcement obligations in their respective national legal systems" ${ }^{936}$. The IPRs framework that emerged with TRIPS universalized standards of protection for certain sectors of industries that were sensitive for developed countries.

Yet, although TRIPS is flexible in what concerns to the national level of protection, the Agreement limits the options that could be available for developing countries and - as a one fits all model - ignores the profound economic and technological asymmetries among members.

Thus, the TRIPS Agreement was since the beginning much more favorable to developed economies (mainly the US, the EC and Japan) which had a prosper development since the GATT regarding intangible goods and services protected by intellectual property. Nevertheless, since 1999 - when Ecuador surprisingly proposed a cross-retaliation on IP rights - the scenario has changed. Suspending obligation under TRIPS and threatening to attack a very sensible sector of IP dependent-industries of developed economies turned out to be a great weapon in the dispute settlement system.

Several considerations can be made regarding the use of suspending TRIPS obligation in a cross-retaliation procedure - always considering a developing member in the

\footnotetext{
${ }^{334}$ See TRIPS Agreement.

335 See Correa, 2000, p. 2. The obligations referring to the implementation of the standards set out by TRIPS were phased over various transitional periods depending upon the level of development of the WTO member concerned.
} 
complainant seat and a developed member as the respondent. Further on in this chapter an attempt to encompass all or at least the most important issues and concerns in this mechanism will be made. For now, it seems that cross-retaliating on IP rights do increase the harm for the retaliated member and, at the same time, results in an increase of welfare in the complainant developing member.

\subsubsection{Intellectual Property Rights}

An introduction to the typology of intellectual property rights is pertinent to this study, since each type of IP right has its peculiarities. The different characteristics influence the feasibility and effectiveness - or not - of applying cross-retaliation affecting one or other intellectual property right protection.

The diverse IP rights are going to be briefly detailed in this section with the aim of building the necessary ground for a deeper discussion on the suspension of TRIPS obligations. In fact, during the explanation of each intellectual property right category, a preliminary reflection on its suspension under TRIPS will be offered.

Broadly spread as an alternative for developing countries to induce first compliance and then re-balance trade conditions, this research raises some concerns about the effectiveness of the cross-retaliation on IP rights regarding developing members.

Therefore, some of the IP rights seem to be particularly more interesting than others considering the possibility of cross-retaliation. Due to the fact that cross-retaliation is meant to be a temporary measure, the IP rights chosen for the purpose of cross-retaliation should be carefully studied in each dispute. Considering the specific situation and the peculiarities of each IP right, some are more feasible, practicable and effective than others to have their obligations suspended, depending on the impact caused in the specific situation as it is going to be further discussed in the following sections of this chapter.

The categories of IP right that will be addressed below follow the structure of the TRIPS agreement. There may be different forms of dividing the categories of intellectual property rights, but so as to proceed straightforward to the main discussion aimed in this

\footnotetext{
${ }^{336}$ Abbott, 2009, p. 3.
} 
chapter, the division proposed was considered to be appropriate. Also, greater emphasis is placed on trademarks, patents and copyrights, since they seem to be - at least for the sake of this research - much more interesting regarding the different possibilities for cross-retaliation.

\section{- Trademarks}

Trademarks are a type of industrial property that refers to signs or symbols that indicate an origin. They enable the public to distinguish between goods and services from different sources, playing a key role in a market economy as it is valuable to the consumer and to the owner of the brand.

With trademarks, consumers can select products on the market and, by selecting, they can give the owner of the brand a feedback and an incentive to produce high-quality goods - considering, of course, that the consumer is primary interested in the quality of the product when he chooses a certain brand ${ }^{337}$. Indeed, the quality of the goods or services sold in connection with a mark (brand) is also an important function or reason for a trademark to be protected.

Following the organization of Laurie et.al., a trademark has four basic functions: it is a badge of origin, an indication of quality, a means of advertising and an investment vehicle $^{338}$. The first and second functions were briefly outlined before in this study. The third function - means of advertising - refers to the advertising of the goods or services sold by the trade in connection with a mark (to bring to the attention of the public a particular mark). $\mathrm{T}$ The last functions pointed out by the authors refer to the time and money that is normally spent on building consumer awareness of a particular mark $^{339}$.

Thus trademarks aim to assure that consumers make the right choice. They create a diverse and competitive market where the consumers are willing to pay different prices depending on the diversity/quality of the product. Therefore, one of the basic functions of a trademark is to identify an origin and avoid confusion.

\footnotetext{
${ }^{337}$ See Tritton, 2008, p. 225.

${ }^{338}$ See Laurie; MacQueen; Waelde, 2008, p. 537-547.

${ }^{339}$ Ibid., p. 544. The authors also explain that the advertisement, quality and investment functions are commonly referred to as 'communicative functions' of a trademark.
} 
Certainly we can infer that confusion leads to a situation where a consumer cannot make a rational choice ${ }^{340}$. In fact, the trademark framework is designed to prevent competitors from confusing consumers into thinking that they are acquiring goods and services from a trusted and original source when they are not ${ }^{341}$. If that is the case, the trademark law can be used to prevent the competitor who is confusing the consumer from doing so.

Note that in order to avoid confusion, no registration of the trademark is necessary. The registration is not necessary to identify an origin of a trademark. Nevertheless, nowadays all the countries have a trade system and a registration system, which can work in a very particular way. For example, in some countries the grant of a trademark can be based only in the registration while in others the trademark may arise from the use in commerce. Still, some trademarks are currently registered even before they are used.

Also note that the registration is territorial, but the trademark is not to the extent that the same mark can be used and recognized in multiple jurisdictions. Trademark can be recognized from the use in commerce and they are of a potentially indefinite duration, as pointed out by Abbott ${ }^{342}$.

As they also indicate an origin, geographical indications, trade names and domain names are studied together with trademarks ${ }^{343}$. Nevertheless, special attention will be given only to geographical indications (later on in this section), since they are more pertinent to the current discussion.

\footnotetext{
${ }^{340}$ Rational choice involves rational evaluation, investigation of what the consumers is going to buy. It requires transparency of the product and perfect conditions to distinguish the original from the fake. More about rational choice can be read online in the Stanford Encyclopedia of Philosophy, available at: < http://plato.stanford.edu/entries/economics/\#5>.

${ }^{341}$ The international framework for trademark is composed by: the TRIPS Agreement (WTO), Paris Convention, Berne Convention, Madrid Agreement, Madrid Protocol, Trademark Law Treaty, Singapore Treaty and Nice Classification. Except for the TRIPS, all the other agreements are administered by WIPO.

${ }^{342}$ See Abbott, 2009, p. 27-28.

${ }^{343}$ Trade names and domain names can also be classified as a subset category of trademarks. Trade names are used under commercial purposes. According to Article 8 of the Paris Convention: "A trade name shall be protected in all the countries of the Union without the obligation of filing or registration, whether or not it forms part of a trademark". Domain names are the addresses of web sites that are intended to be easily identifiable (such aswto.org or wipo.int). A lot of disputes arises in the WIPO regarding domain names. As aforementioned, the Organization has a system of arbitration and mediation specialized for settlement domain names disputes.
} 
Regarding the suspension on TRIPS obligations concerning trademarks, it may be quite problematic. As trademark law is designed to protect the consumer, the suspension on its rights may lead to a complicate situation in the domestic market of the retaliator.

First, during the period of suspension on trademark obligations under TRIPS, the consumers who are used to the real trademark and its originality and quality may not wish to purchase products from another source, once they could be of inferior quality. By adopting this measure, the government may cause consumer dissatisfaction. Second, the reputation of a trademark in the domestic country may be suffering irreparable damage for a long-term, and this may also be undesirable for the economy of the developing country applying crossretaliation measures ${ }^{344}$.

However, as noted by Abbott, a decision on whether to suspend a protection on a trademark may be influenced by whether and where the retaliating country already maintains a significant counterfeit market related to the specific trademark. If the WTO member already has a significant counterfeit market and if the consumers normally do not expect to purchase original goods, then the risk of harming the domestic economy is undermined. On the other hand, if that is the situation, larger multinational enterprises - which invest heavily in advertising their own trademarks - may pressure the government of the respondent member to comply with the decision adopted by the $\mathrm{WTO}^{345}$.

The preliminary conclusion is that, if the circumstances are the ones above indicated suspending trademarks as cross-retaliation mechanism could be a significant weapon of pressure to induce compliance. Notwithstanding, one last consideration shall be made in what follows.

Abbott calls the attention to the fact that although suspension on trademarks is a possible option for cross-retaliation, it may face problems regarding foreign trade actions. A suspension of a trademark within a national territory will not suspend the same protection in other national territories - as trademarks are granted in a country-to-country basis. So if products produced under a suspension of trademark protection are exported, it may result in

\footnotetext{
344 Ibid.

345 Abbott, 2009, p. 28.
} 
other problems to the retaliating country, as it would also affect the level of suspension of trademarks obligations ${ }^{346}$.

\section{- Geographical Indications}

Geographical indications (GI) also refer to a name or a sign that indicates the geographical location or origin of a certain product. Normally, due to the geographical origin, geographical indications are referred to as a certification of the qualities of the product, such as traditional methods and reputation.

As Tritton states, originally, the geographical name was used only to indicate the precedence of the product - region or locality. As time went by, the GI helped customers in their purchasing choice ${ }^{347}$ for products, which were highly regarded by the consumers

TRIPS gives a wide definition of GI referred to as indications for characterizing or identifying "a good as originating in the territory of a Member, or a region or locality in that territory, where a given quality, reputation or other characteristic of the good is essentially attributable to its geographical origin" ${ }^{\prime 34}$.

The wide definition of geographical indications includes the appellation of origin. It means that the requirement of a link between the product reputation and the territory shall be higher ${ }^{349}$.

With a rich history of local and especial agricultural production, geographical indications are particularly important to Europe ${ }^{350}$. With a great protection of its GIs, Europe protects its production methods, encourages its quality production and promotes a significantly rise of income for the region protected by a GI.

\footnotetext{
346 Ibid.

347 Tritton, 2008, p. 450. Note that geographical indications do not protect only agricultural products. For example: Murano glass produced in Venice and Waterford Crystal are protected with GI. See also O'Connor, 2004, p. 18-19.

${ }^{348}$ Article 22.1, TRIPS. The TRIPS agreement discloses a separate article to rule on wines and spirits: Article 23, TRIPS. Beyond TRIPS, the significant international framework for GI includes; the Paris Convention, the Madrid Agreement on Indications of Source and the Madrid Agreement Concerning International Registration of Marks (1891) and the Lisbon Agreement on Appellations of Origin (1958).

${ }^{349}$ WIPO/GEO/BEI/07/15, p. 3.

${ }^{350}$ Some famous examples of Gis in Europe are: Roquefort cheese, Scotch whisky, Parmigiano Reggiano, Parma Ham and Champagne.
} 
Not without reason the geographical indications are a central topic of discussion in the current Doha Round. Europe has been pushing for the enhancement of its protection, and at the same time has been more and more demanded on the topic in the DSB, and developing countries have been increasingly fighting to protect their own GI.

Like trademarks, suspending GI obligations under TRIPS seems to be counterproductive. First, the consumers may not be interested in purchasing a product with inferior or different quality if they appreciate the original product protected by the GI. Second, as a geographical indication is protected in a country- to -country basis (as is a trademark) and it is entirely dependent on national legislation, its protection can widely vary. However, due to the variety on the legislation protection, Abbott points out that it may be "possible that some potential destinations for exports would not protect a given GI so that there would be no specific legal impediment to exportation and importation" 351 .

\section{- Patents}

According to the definition of the WIPO, a patent is an exclusive right granted for an invention. The invention can be a product or a process that normally provides a new technical solution for a problem or offers a new way of doing something ${ }^{352}$.

Patent is a territorial right that gives the inventor a monopoly excluding others from commercially exploiting the invention. The logic of the patents is to provide incentives to innovation, by offering inventors recognition and economic reward for their creativity and work.

Patent right gives the owner of the patent a limited period of protection, which is normally of 20 years counting from the filling date of the patent application ${ }^{353}$. The commercial exploitation of the invention works as a reward or an exchange to disclose to the public.

\footnotetext{
${ }^{351}$ Abbott, 2009, p. 29.

${ }^{352}$ WIPO. Information available at: $<$ http://www.wipo.int/patentscope/en/patents_faq.html\#protection>. The first patent system is considered to be the Venetian one, around 1450. See David, 1992.

${ }^{353}$ See Article 33, TRIPS.
} 
Thus, patent protection means that no one but the patent owner can commercially make, use, distribute or sell it. Everyone else who intends to do something commercially with the patent, needs the patent owner's consent. During the period that the patent is granted, the patent owner is the only one who can evaluate and give permission or license for the use of his invention ${ }^{354}$.

In return for patent protection, the patent owners are obliged to disclose information on their invention to the public in order to enrich the knowledge in the world. According to WIPO:

Such an ever-increasing body of public knowledge promotes further creativity and innovation in others. In this way, patents provide not only protection for the owner but valuable information and inspiration for future generations of researchers and inventors ${ }^{355}$.

The national patent office(s) and/or the regional office are the institutions responsible for granting (or refusing) the patent ${ }^{356}$. The Patent Cooperation Treaty (PCT) provides, for the designated countries the filling of a single international patent application which has the effect of a national application ${ }^{357}$. The inventor-applicant may file one application and request for protection in as many signatory states as wanted.

For industrial property, the Paris Convention established a priority right for granting the right of protection. According to its Article 4.1, any person "who has duly filed an application for a patent [...] in one of the countries of the Union, or his successor in title, shall enjoy, for the purpose of filing in the other countries, a right of priority during the

\footnotetext{
${ }^{354}$ The owner may also sell the right to the invention to someone who will then become the new owner of the patent.

355 WIPO. Available at: <http://www.wipo.int/patentscope/en/patents faq.html\#protection>. The significant international framework for the patens system includes beside the TRIPS Agreement, the Paris Convention, the Patent Cooperation Treaty 1970 and the Patent Law Treaty 2000 (all administered by WIPO).

${ }^{356}$ For example, the national patent office in Brazil is the National Institute for Industrial Property (INPI). Information available online at: $<$ http://www.inpi.gov.br/ $>$. Regarding the regional offices, the most famous and busy regional office is the European Patent Office (EPO). Information available online at: < http://www.epo.org/>. Note that under a regional system, the applicant can request protection for the invention in one or more countries that are part of the system, and each country decides individually as to whether to offer patent protection within its borders. See WIPO.

357 The Patent Cooperation Treaty is administered by WIPO and it is available online at: < http://www.wipo.int/pct/en/texts/articles/atoc.htm>.
} 
periods hereinafter fixed"358. The period of priority for patens is of 12 months, counting from the filling date d59. $^{359}$.

Regarding the inventions that can be protected, the WIPO explains that the invention shall fulfill the following conditions: must be of practical use, must show an element of novelty - that is, some new characteristic which is not known in the body of existing knowledge in its technical field (prior art) -, and must show an inventive step. Although there is no real evidence that the patens contribute to innovation and/or to economic activity, the inventor only gets a patent if it contributes to society.

Once the protection ends, the patent expires and the owner does not hold the exclusive rights anymore and the previously protected invent enters the public domain for the exploitation by others.

\section{Suspension on patents under TRIPS}

The suspension of patents under TRIPS seems to be a very attractive option and might take a variety of forms. Although patents are subject to exceptions that cannot be dismissed under the TRIPS Agreement - such as the compulsory license and the limit exceptions that may be adopted by national authorities ${ }^{360}-$, the suspension of these obligations are interesting to developing countries.

According to Abbott, suspension on patent obligations could be applied to a specific patent or category of patents or, instead, it could be applied across the entire range of patents that have been granted by the suspending country. Also, the author points out that one good advantage of this option for cross-retaliation is that the patent holder is supposed to have already disclosed a great part of the technical information about the invention in a way that will allow third parties to practice the invention ${ }^{361}$.

The suspending country might choose to suspend certain categories of patents or some patents of the patent holder and not others. That can lead to a discussion on whether

\footnotetext{
${ }^{358}$ Article 4.1, Paris Convention.

359 Article 4, c (1), Paris Convention.

${ }^{360}$ See Article 30 and 31 of the TRIPS Agreement.

${ }^{361}$ See Abbott, 2009, p. 25.
} 
electing some patent rights to suspend and not others would configure discrimination under Article 27.1 of the TRIPS. Nevertheless, the suspending country can argue and justify that before a suspension situation, different categories of patens should be treated differently.

As trademarks, patents are granted in a country-to-country basis. This raises the same issue previously mentioned when reflecting about trademarks, since the suspension of the patent right in country A does not mean the suspension in country B. If the export of a product manufactured with suspension of patent rights is considered from country A to country B - where the product is still patented -, this situation may raise trade problems.

Notwithstanding, Abbott states that "it is quite likely that for any invention placed on the market in a suspending country there will be a significant number of potential export destinations where parallel patents will not be in force" ${ }^{\$ 362}$. Indeed, the availability of export markets shall be taken into account regarding the level of suspension of concessions in cross-retaliation.

As a temporary measure, since the countermeasures are intended to be temporary either in retaliation or cross-retaliation procedure, the suspending country must reconsider the establishment of a new scenario when the suspension is terminated. The reintroduction of the patent right to the patent holder shall need to consider issues like the exemption from infringement claims for activities during the period when the suspension was valid; the right to sell off the remaining products/inventories and the continued use of products protected by patents sold during the suspension period ${ }^{363}$.

The process of suspending patent rights can also be considered in a manner equivalent to a compulsory license, but without the payment of compensation. Considering social welfare, Abbott considers that a country might primarily considerer issuing compulsory licenses for the importation of generic pharmaceutical products that could be substitutes for the - normally expensive - patented pharmaceutical products in the market ${ }^{364}$. Because of the commonly available information about price of volume of trade on patented products, governments shall be capable of inferring the savings that might come out from the suspension on patent rights in the pharmaceutical sector.

\footnotetext{
${ }^{362}$ Id., p. 26.

${ }^{363}$ Ibid.

${ }^{364}$ Abbott, 2009, p. 37.
} 
Interesting to mention the US-Cotton case, in which Brazil threatened to suspend the transfer of royalty payments to US pharmaceutical industries like Pfizer in a crossretaliation action to the country's illegal cotton subsidies.

The case was largely publicized through the media once if the threat was concretized it would generate an immediate reaction from strong pharmaceutical industries of the US. As mentioned ahead in this dissertation, cross-retaliation under TRIPS holds a great potential of creating lobbies in the noncompliant country member to pressure the government for a solution of the problem.

In the US-Cotton, if Brazil had go on with its decision of retaliating pharmaceutical patents, industries such as Pfizer would normally end up lobbying the politicians in favour of an effective solution to the problem. Brazil had a real threatening weapon in its hands ${ }^{365}$.

\section{- $\quad$ Copyrights and Related Rights}

Copyrights are the rights for the protection of authors, performers, producers and broadcasters. It protects the expressions of authors and artists, including the works involved in businesses such as writing computer programs. According to Smits and Verlinden, "copyright arises from the simple fact of exteriorizing a creation, being it a literary, artistic or other type of work" 366 .

Primary protected by the Berne Convention for the Protection of Literary and Artistic Works, one of the main principles established by the contracting parties is that no formality is required in order to protect a copyright under the Convention. Article 5 (2) states of the Berne Convention that:

\footnotetext{
${ }^{365}$ Basso, 2005, p. 19.

${ }^{366}$ Smits; Verlinden, 2009, p, 157. Only for historical purposes, it is interesting to know that in most European countries the origins of the copyright law "lie in the efforts of government to regulate and control the output of printers once the technology of printing had been invented and become established in the $15^{\text {th }}$ and $16^{\text {th }}$ centuries. [...] this meant much more rapid and widespread circulation of ideas and information". In: Laurie; MacQueen; Waelde, 2008, p. 34. Therefore, the prime term of protection was for the person who was making the economic investment to transform the manuscript into a printed book, for example. See also Tritton, 2008.
} 
(2) The enjoyment and the exercise of these rights shall not be subject to any formality; such enjoyment and such exercise shall be independent of the existence of protection in the country of origin of the work. Consequently, apart from the provisions of this Convention, the extent of protection, as well as the means of redress afforded to the author to protect his rights, shall be governed exclusively by the laws of the country where protection is claimed $^{367}$.

It is interesting to note that the Berne Convention adopts the French approach in the treatment of copyrights. That means that it actually refers to the author's right, a definition that is embedded within the spirit of the French Revolution of 1789: freedom, liberty and brotherhood. Thus, the author's right was considered the right of the creator of the work, such as a natural right. That is the approach used, for example, in Brazil.

On the other hand, the term copyright refers to the English system, which has an economic approach of the subject. The most recent WIPO treaties - including the WIPO Copyright Treaty - follow the English system, which delivers a broad comprehension of copyrights and in which are included the author's right ${ }^{368}$.

More than economic rights, the Berne Convention highlights the protection of moral rights. Article 6 of the Convention establishes the protection of moral rights, which subsist independently of the author's economic right and even after the transfer of the economic rights. The author has always the right to claim authorship and to object to any distortion that could be prejudicial to his honor or reputation ${ }^{369}$.

Still, it is in Article 6 it is guaranteed that even after the author's death, his rights can be exercised - at least until the expiry of the economic rights - by person or institutions authorized by the legislation of the country where protection is claimed ${ }^{370}$. The TRIPS Agreement established the minimum standards of term protection like the following: the term

\footnotetext{
${ }^{367}$ Article 5 (2), Berne Convention.

${ }^{368}$ See Sterling, 2008.

369 Article 6 (1), Berne Convention: “(1) Independently of the author's economic rights, and even after the transfer of the said rights, the author shall have the right to claim authorship of the work and to object to any distortion, mutilation or other modification of, or other derogatory action in relation to, the said work, which would be prejudicial to his honor or reputation".

370 Article 6 (2), Berne Convention: “(2) The rights granted to the author in accordance with the preceding paragraph shall, after his death, be maintained, at least until the expiry of the economic rights, and shall be exercisable by the persons or institutions authorized by the legislation of the country where protection is claimed. However, those countries whose legislation, at the moment of their ratification of or accession to this Act, do not provide for the protection after the death of the author of all the rights set out in the preceding paragraph may provide that some of these rights may, after his death, cease to be maintained".
} 
of protection shall be no less than 50 years from the date of publication for works (from the end of calendar year of authorized publication), or, the author's life plus 50 years $^{371}$.

\section{Suspension on copyrights under TRIPS}

Suspension of copyrights protection under TRIPS could take several different avenues. For instance, instead of excluding the rights, the suspension could attack the way of acting, the use of copyrights. Abbott gives the example in which a suspension of copyrights could authorize film DVDs reproduction, but prohibit their broadcast on television or their public showing in theaters ${ }^{372}$.

Also, suspension of copyrights can be applied attacking the royalties. A limitation on the distribution of royalties received from licensees of works protected by copyrights. That would not affect the right of the copyright holder of excluding others from its use, but would prejudice the licensees' owners. The nullification or impairment could be determined by the level of royalties' payments. Actually in the dispute US- Copyright, that was exactly what arbitrators suggested in the recourse to arbitration under Article 25 of the DSU:

4.40 In their calculation, the Arbitrators have attempted to estimate the amount of royalties that EC right holders received, prior to the entry into force of the 1998 Amendment, for the use of broadcast music from the types of establishments that were newly exempted by that Amendment. For that purpose, we have used the historical data available to us regarding the receipts of the two biggest US CMOs to whom EC right holders have entrusted the licensing of their rights - ASCAP and BMI. As we have noted before, both parties consider that the amount of royalties paid to EC right holders by the third US CMO, SESAC, is insignificant.

4.41 Relying on this historical data means that our calculation takes into account the licensing income from those establishments that used broadcast music at that time and had acquired a license from ASCAP or BMI. Our calculation does not include any hypothetical amount of royalties from those establishments that did play broadcast music but had not acquired a license from the CMOs in question. [... $]^{373}$.

\footnotetext{
${ }^{371}$ See Article 12, TRIPS. Note that these are minimum standards of term of protection. For that reason, the mentioned period can be extended in some jurisdictions.

${ }^{372}$ See Abbott, 2009, p. 23.
} 
Considering the digital environment, Abbott also raises the concern about the difficulty of controlling the spread of information (also confidential information) through digitalization, electronic reproduction and transmission. Indeed, the suspension of copyrights related to digital material may expose the work retransmission and/or reproduction worldwide, which could be truly difficult to control ${ }^{374}$.

As patents, copyrights are also independent rights, granted in a country-to-country basis. That means that issues involving export of products that are produced in a suspension of copyrights obligations basis can be problematic.

\section{- Industrial Design}

According to WIPO definition, "an industrial design constitutes the ornamental or aesthetic aspect of an article. A design may consist of three-dimensional features, such as the shape or surface of an article, or of two-dimensional features, such as patterns, lines or colors" ${ }^{\prime 375}$. It could be explained as a combination of applied art and applied science, which is interested in studying function and form of the objects.

Industrial design can be understood as a particular type of work that might have been protected only by copyright but to which has been given a special regime since the $19^{\text {th }}$ century. The reason for the special regime was the concern with the end results of mass production, different from the individual creative efforts (the essence of copyrights) ${ }^{376}$.

The basic form of design protection is registered in a public register maintained by national governments and depends upon the registration. The Berne Convention established minimum substantive protection regarding copyright law. Nevertheless, there is no similar international treaty for industrial design protection. Only the Paris Convention, in its Article 5, states that "industrial design shall be protected in countries of the Union", but does not provide further details about how the protection might work ${ }^{377}$.

\footnotetext{
${ }^{373}$ WT/DS160/ARB25/1, p. 28.

${ }^{374}$ See Abbott, 2009, p. 23-25.

${ }^{375}$ See WIPO. Available online at: < http://www.wipo.int/hague/en/general/>.

${ }^{376}$ See Laurie; MacQueen; Waelde, 2008, p. 251-252.

${ }^{377}$ Id., p. 254-255.
} 
In 1995, TRIPS Agreement established a minimum standard of protection of 10 years for industrial designs. Article 26.1 states that the owner of a protected industrial design, when commercial purposes are undertaken, "shall have the right to prevent third parties not having the owner's consent from making, selling or importing articles bearing or embodying a design which is a copy, or substantially a copy, of the protected design" ${ }^{\prime 378}$.

Abbott interprets the suspension of industrial designs as a possible useful tool for inducing compliance with DSB/Appellate Body decisions. This author gives as an example the sector of textiles/clothing. In the domestic market, consumers could take advantage of similar or identical textile products, from the original producer, if the suspending country authorizes manufactures to produce copies of designs from the respondent member ${ }^{379}$.

\section{- Integrated Circuits}

Integrated circuits are electronic circuits used virtually in all electronic equipment today, such as cell phones and computers. The protection of integrated circuits is established by the Article 38 of the TRIPS Agreement of a minimum of 10 years $^{380}$.

The suspension of an integrated circuit protection might imply the importing, selling or distributing a protected layout-design (as referred by TRIPS) for commercial purposes.

Considering that only countries with expertise, knowledge and available resources to invest in integrated technologies circuits, it appears to be complicated to believe that this would be a good opportunity for developing countries with cross-retaliation purposes.

Also, it seems difficult to believe that right holders of integrated circuit in import markets would like to approve the importation of integrated circuits produced under a suspension of intellectual property rights in the exporting country ${ }^{381}$.

\footnotetext{
${ }^{378}$ Article 26.1, TRIPS.

${ }^{379}$ See Abbott, 2009, .p. 29.

${ }^{380}$ The TRIPS Agreement refers to integrated circuit as layout-design.

${ }^{381}$ See Abbott, 2009, p. 30.
} 


\section{- Undisclosed Information (trade secrets)}

Undisclosed information (trade secrets) refers to information that is not available to the general public - as the name suggest, it is a secret. Normally these pieces of information confer some sort of economic benefit to its holder because of their secret.

According the US Code, Title 18, Part I, Chapter 90:

$\S 1839$ the term "trade secret" means all forms and types of financial, business, scientific, technical, economic, or engineering information, including patterns, plans, compilations, program devices, formulas, designs, prototypes, methods, techniques, processes, procedures, programs, or codes, whether tangible or intangible, and whether or how stored, compiled, or memorialized physically, electronically, graphically, photographically, or in writing if-

(A) the owner thereof has taken reasonable measures to keep such information secret; and

(B) the information derives independent economic value, actual or potential, from not being generally known to, and not being readily ascertainable through proper means by, the public ${ }^{382}$.

If compared with patents for example, trade secrets are quite complicated to be an effective mechanism for suspension under TRIPS considering a cross-retaliation. Abbott calls attention to the fact that little immediate information would be available to third parties from the suspension of undisclosed information protection. While in patents all the relevant technology is disclosed in the patent application - becoming publicly available to third parties -, additional important informational of trade secrets could become public only if the right holder wishes $\mathrm{so}^{383}$.

An additional problem pointed by the author regarding the calculation of the level of suspension is that it would have to take into account the continuing nature of the effect of disclosing a trade secret, since once disclosed there is no way to put back upon the termination of the suspension regime ${ }^{384}$.

\footnotetext{
382 US Code, Title 18, Part I, Chapter 90, $\S 1839$. Available online at: $<$ http://www.law.cornell.edu/uscode/18/1839.html $>$.

${ }^{383}$ See Abbott, 2009, p. 30.

${ }^{384}$ Ibid.
} 
For the sake of closing the present section, please find below a reproduction of a useful table presented by Paul Flignor and David Orozco in a paper for WIPO that summarizes the main topics discussed above:

\begin{tabular}{|c|c|c|c|c|c|}
\hline IP Regime & Origin of Rights & $\begin{array}{l}\text { Prerequisites to } \\
\text { Protection }\end{array}$ & Scope of Protection & Life & $\begin{array}{l}\text { Test for } \\
\text { Infringement }\end{array}$ \\
\hline Trademark & $\begin{array}{l}\text { Adoption \& use in } \\
\text { commerce }\end{array}$ & $\begin{array}{l}\text { Used in commerce } \\
\text { to identify and } \\
\text { distinguish business, } \\
\text { goods and services, } \\
\text { Federal registration } \\
\text { required for federal } \\
\text { enforcement. }\end{array}$ & $\begin{array}{l}\text { Words, names, } \\
\text { symbols, and other } \\
\text { devices. }\end{array}$ & $\begin{array}{l}\text { Unlimited as long } \\
\text { as property is used } \\
\text { in commerce. }\end{array}$ & $\begin{array}{l}\text { Likelihood of } \\
\text { confusion, mistake } \\
\text { or deception. }\end{array}$ \\
\hline Patent & $\begin{array}{l}\text { Granted by Fed. } \\
\text { Govt. on application } \\
\text { by inventor }\end{array}$ & $\begin{array}{l}\text { New, useful, and } \\
\text { non-obvious subject } \\
\text { matter }\end{array}$ & $\begin{array}{l}\text { Useful process, } \\
\text { machine, article of } \\
\text { manufacture, or } \\
\text { composition of } \\
\text { matter }\end{array}$ & $\begin{array}{l}17 \text { years from date } \\
\text { of grant or } 20 \\
\text { years from date of } \\
\text { application }\end{array}$ & $\begin{array}{l}\text { Manufacture, use, } \\
\text { sale, offer for sale in } \\
\text { U.S., or import of } \\
\text { claimed invention. }\end{array}$ \\
\hline Copyright & $\begin{array}{l}\text { Creation of original } \\
\text { "works" of } \\
\text { authorship, fixed in } \\
\text { tangible form }\end{array}$ & $\begin{array}{l}\text { Originality, } \\
\text { registration and } \\
\text { copyright notice } \\
\text { required if publicly } \\
\text { enforced }\end{array}$ & Works of authorship & $\begin{array}{l}\text { Variable on the } \\
\text { order of } 100 \text { years } \\
\text { or longer; life of } \\
\text { author plus } 70 \\
\text { years. }\end{array}$ & $\begin{array}{l}\text { Copying, } \\
\text { Performing, } \\
\text { Distributing }\end{array}$ \\
\hline Trade Secret & $\begin{array}{l}\text { Investment of time } \\
\text { and money, guarded } \\
\text { from others }\end{array}$ & $\begin{array}{l}\text { Recognition of } \\
\text { value and utility }\end{array}$ & $\begin{array}{l}\text { Confidential } \\
\text { Information }\end{array}$ & $\begin{array}{l}\text { Life of } \\
\text { confidentiality }\end{array}$ & $\begin{array}{l}\text { Means of } \\
\text { Derivation }\end{array}$ \\
\hline
\end{tabular}

Table V - IP Regimes ${ }^{385}$

\subsection{TRIPS as part of the WTO: cross-retaliation}

Since the cross-retaliation mechanism was brought to the dispute settlement scene by a request of Ecuador, suspension on TRIPS obligation has been calling the attention of WTO scholars and practitioners.

Normally, the idea of cross-retaliation attacking intellectual property rights of developed countries- although never put in practice - is understood as a good alternative for developing countries in order to promote the apparent three main objectives of retaliation: to induce compliance, to re-balance the trade relation between WTO members involved and to 
promote a credible threat to developed countries. Since the traditional retaliation on tariffs appears to be ineffective when the economic asymmetry of the countries places the developing members in a delicate situation, cross-retaliation by the suspension on TRIPS obligations seems to do a much better job. Indeed, authors have argued in the past and present decade that "retaliation in TRIPS can be genuinely welfare enhancing in a way that conventional retaliation... is not ${ }^{\prime \prime 386}$.

The present study proposes the reflection on two issues at this point. The first is whether suspending intellectual property rights from developed countries really promotes an effective instrument in inducing compliance with a DSB decision. This will be discussed in the present chapter. The second issue is going to be the main subject of the fifth chapter as it regards whether the compliance of the cross-retaliation in intellectual property rights addresses the basic issue of (non) compliance with DSB decisions.

When countries wish to retaliate in a way different from the traditional retaliation, therefore requesting the suspension of obligations under a different WTO agreement from the one where the inconsistency was reclaimed, the suspending members have to provide details for their request. Complaining members have to show why the retaliation through classic imposition of tariff duties is neither practical nor effective and, at the same time, explain why cross-retaliation - under TRIPS obligations in the case of this research - is more effective in inducing compliance and producing a gain of social welfare to the complaining member. As is going to be demonstrated in section 4.3.2, Antigua was quite successful in doing so.

At a first glance, explaining the reasons for the request of a cross-retaliation procedure may seem like a simple procedure. It is not. Among the many challenges of applying and justifying cross-retaliation in TRIPS obligations is the calculation of the level of suspension, as it has to be equivalent and proportional to the level of nullification and impairment discussed in the dispute.

It should be clear at this point that once the panel determines the level of impairment, and considering cross-retaliation in intellectual property rights, the panel cannot decide which IP rights shall be suspended or decide which rights will result in an equivalent

\footnotetext{
${ }^{386}$ Subramanian; Watal, 2000, p. 405.
} 
and proportional loss. The panel shall only pay attention to whether the suspension is not exceeding the level of nullification or impairment ${ }^{387}$.

Differently from the imposition of tariff duties on goods, suspension on TRIPS obligations presents some difficulties for its calculation, given the fact that it is not very obvious. It can be easy to picture the gains from suspension on payment of royalties on copyrights, for example, but the calculation cannot be that logical regarding suspension on other IP rights (as it was briefly showed in the previous section, and as it is going to be further discussed in section 4.2.1)

Also, implementing suspension in intellectual property rights in national legal systems may prove to be complex. Most of the WTO members do not have a proper judicial mechanism in their domestic legal system to allow the implementation of result from a crossretaliation procedure in a simple way.

Yet, beyond the challenges of valuing IP and implementation in the domestic legal system, there are other issues that should be taken into account regarding the feasibility or not of the intellectual property rights for developing countries are, such as: the costs involved in a cross-retaliation procedure, the violation (or not) of international treaties, and the required basic knowledge to take advantage of a suspension in the rights of an IP right.

For the sake of organization, this section is going to be subdivided into two subsections. The first will deal with basic issues of calculation on the level of retaliation concerning IP rights. The second will discuss issues related to the enforcement of intellectual property rights and national legal systems.

\subsubsection{Basic rationale to calculate the level of retaliation}

The calculation on the level of retaliation when suspending obligation under TRIPS is one of the most critical issues related to cross-retaliation. As stated before, the major "challenge in any IP cross-retaliation model is the uncertainty inherent in valuing intellectual property rights and determining an optimal royalty rate that represents the true value of loss to the IP owner" ${ }^{\prime 38}$. As the rights involved are intangible assets with economic and moral values,

\footnotetext{
387 See Basheer, 2009, p. 32.

${ }^{388}$ Basheer, 2009, p. 45.
} 
the calculation is not as straightforward as in a traditional retaliation with the imposition of tariff duties ${ }^{389}$.

The valuation of intellectual property rights is in itself a very critical area in finance, as it cannot be defined or specified by physical parameters. The level of protection of intellectual property rights can derive its value from parameters such as market share, legal protection, level of profitability, barriers to enter the market, technology and industrial factors.

The difficulty of assessing IP rights is reflected in the challenging job of calculating an equivalent and proportional level of retaliation when it comes to suspension on TRIPS obligations. As already addressed in this chapter, the complainant member that requires the right to proceed with cross-retaliation in TRIPS has to clearly show why that is necessary and how the retaliation is going to be calculated taking into account the level of nullification and impairment of the original inconsistent measure in dispute.

Note that pursuant Article 22.7, the arbitrator "shall not examine the nature of the concessions or other obligations to be suspended but shall determine whether the level of such suspension is equivalent to the level of nullification or impairment". That means that the DSU does not elaborate upon specific categories of intellectual property rights to be suspended. Thus, the complaining member wishing and allowed to cross-retaliate in TRIPS has considerable flexibility on the subject ${ }^{390}$.

Since this study does not aim at exploring economic variables the elements that are considered fundamental for the study and the rationale for the calculation will be addressed from a legal point of view, without addressing mathematic models or calculations.

\footnotetext{
${ }^{389}$ Note that regarding moral rights, it is really complicated to find a plausible outcome, since the moral rights pursuant Article 6bis of the Berne Convention - were not incorporated by the TRIPS Agreement. Therefore, an order to cross-retaliate cannot take into account moral rights of authors from the respondent member. For more specific information on valuation of intellectual property rights, see Kamiyama; Martinex; Sheehan, 2006.

${ }^{390}$ See Abbott, 2009, p. 25.
} 


\title{
- $\quad$ Equivalence
}

According to Article 22.4 of the DSU, the level of suspension of concession or other obligations shall be equivalent to the level of nullification or impairment. Paragraph 4.1 of the decision by the arbitrators in the EC-Bananas III in defining equivalence stated that:

\begin{abstract}
We note that the ordinary meaning of the word "equivalence" is "equal in value, significance or meaning", "having the same effect", "having the same relative position or function", "corresponding to", "something equal in value or worth", also "something tantamount or virtually identical". Obviously, this meaning connotes a correspondence, identity or balance between two related levels, i.e. between the level of the concessions to be suspended, on the one hand, and the level of the nullification or impairment, on the other ${ }^{391}$.
\end{abstract}

When the calculation of the level of suspension has to regard a traditional retaliation of imposition of tariff duties, it is easier to calculate the equivalence in crossretaliation on IP rights, although it is never an easy job. As suspension of intellectual property rights might involve a number of other variables and costs - such as the rights of the IP holder, customer confusion concerning suspension on trademarks or the interest of making an undisclosed information available for the public -, the calculation of equivalence has to take into account details that do not come to the game in traditional retaliation.

Indeed, in the US-Gambling the panel acknowledged the difficulty of calculating the suspension of concessions under TRIPS stating that in fact the retaliation under TRIPS Agreement "may involve more complex means of implementation than, for example, the imposition of higher duties on goods, and that the exact assessment of the value of the rights affected by the suspension is also likely to be more complex" ${ }^{{ }^{3} 92}$.

Basheer comments that in a context such as music and sound recording copyrights it may be relatively easy to calculate the level of suspension, since there are data from social rates established by collecting societies for instance. Nevertheless, in the context of suspension of patents and trademarks for example, it may be difficult to (i) value the patent or trademark in question and (ii) determine the value of loss by the suspension and consequent

\footnotetext{
${ }^{391}$ WT/DS27/ARB, p. 8.

${ }^{392} \mathrm{WT} / \mathrm{DS} 285 / \mathrm{ARB}$, p. 77.
} 
use and enjoyment of the intellectual property right by the complaining member government or entity ${ }^{393}$.

Based on the approach made by the arbitrators in the EC-Bananas III, the understanding was to calculate the level of nullification or impairment by making a comparison between the trade value in an actual WTO-inconsistent situation with the trade value expected under a WTO-consistent situation. Thus, the arbitrators require the level of suspension of concessions to be identical to the calculated level of nullification or impairment. In doing so, the analysis of the equivalence is exclusively quantitative ${ }^{394}$.

Some concerns may be raised as to whether the equivalent countermeasures are effective enough in inducing compliance with DSB decisions. That is where the requirements of improvement to strengthen the countermeasures of the multilateral trading system reside ${ }^{395}$.

\section{- Proportionality}

Proportionality is a principle/requirement of international public law, well recognized by jurisprudence, doctrine and practice. Indeed, it is suggested that the principle of proportionality "is one of the more basic principles underlying the multilateral trading system" ${ }^{396}$. Article 51 of the text adopted by the International Law Commission (ILC) on its fifty-third session on the draft articles of State Responsibility for International Wrongful Acts states that: "countermeasures must be commensurate with the injury suffered, taking into account the gravity of the internationally wrongful act and the rights in question" ${ }^{\prime 397 .}$

According to the theory of State responsibility, the requirement of proportionality provides a measure of assurance that the countermeasure applied will not be excessive and disproportionate to the injury caused (which then could give rise to international responsibility of the State applying the countermeasure).

\footnotetext{
${ }^{393}$ See Basheer, 2009, p. 20.

${ }^{394}$ WT/DS27/ARB, p. 41-43.

${ }^{395}$ See Fukunaga, 2006, p. 419-420.

${ }^{396}$ Hilf, 2001, p. 120.

${ }^{397}$ See Yearbook of the International Law Commission (Part II), 2001, p. 30. See also Kelsen, 2003, p. 21.
} 
From the reading of Article 51 of the text adopted by the ILC above, there are two elements that shall be considered while determining the proportionality of the countermeasure: (i) the gravity of the internationally wrongful act and (ii) the rights in question. This implies not only a quantitative approach of the proportionality of the act, but also a qualitative dimension. The strictest view is to assess proportionality only through a correspondence between the concessions suspended and the injurious consequences of the breach of a WTO obligation, therefore considering only a quantitative dimension ${ }^{398}$.

As it is, the WTO law does not consider the "gravity of the wrongful act". The countermeasures are defined according to the level of nullification or impairment (injury) suffered as a result of a breach of a multilateral trade obligation. Thus, the gravity of the injury will not determine the level of suspension of concessions. The first consequence of this is that even when a member simply decides not to comply with a DSB recommendation, currently there are no instruments to extend the members' responsibility taking into account the gravity of the inconsistent measure. That signals to the fact that in the DSU there is no punitive dimension of its available measures for retaliation, although the aim is indeed to induce compliance ${ }^{399}$.

In the case of the WTO cross-retaliation, suspension of concession is more likely to achieve proportionality if they are taken under the same agreement, referring to the same nature of injury related to the reclaimed inconsistent measure. That might not be as obvious regarding suspension on TRIPs obligations as a cross-retaliation measure.

Article 46 of the TRIPS agreement makes an explicit reference to the proportionality requirement: "[...] the need for proportionality between the seriousness of the infringement and the remedies ordered as well as the interests of third parties shall be taken into account $[\ldots]^{\prime 400}$. By looking at the amount of collective duties and the reduction of trade flows, the complaining members requiring suspension of concessions under TRIPS shall be able to calculate and demonstrate with reasonable accuracy the level of the injury resulting from the inconsistent measures of the respondent ${ }^{401}$.

\footnotetext{
${ }^{398}$ See Fukunaga, 2006, p. 420.

${ }^{399}$ See Desmedt, 2001, p. 448.

${ }^{400}$ Article 46, TRIPS Agreement.

${ }^{401}$ See Abbott, 2009, p. 19.
} 
Calculating the level of nullification and impairment and connecting the calculation with the equivalence and proportionality required by the DSU is not an easy task for the complaining members asking for cross-retaliation in TRIPS.

\section{- Social Welfare}

Pursuant Article 7 of the TRIPS Agreement, the enforcement and protection of intellectual property rights should:

[...] contribute to the promotion of technological innovation and to the transfer and dissemination of technology, to the mutual advantage of producers and users of technological knowledge and in a manner conducive to social and economic welfare, and to a balance of rights and obligations ${ }^{402}$.

The increase of social welfare is one of the main reasons to justify suspension of concessions under TRIPS obligations. Most of the knowledge-based/intellectual propertybased industries belong to the developed world. This is explained by the fact that wealthy countries are the ones that possess financial resources to invest in research and development of new technologies and overall new intellectual property assets.

As most trademarks and patents, trade secrets are property of rightholders from developed members, the developing countries normally have to pay a high price to the rights holder in order to have access to products protected by IP law. In a cross-retaliation scenario, the clearest benefit to the consumers resides in not having to pay the price of a protection of an IP right.

For example, if the retaliating country considers addressing public health concerns, the member could choose to suspend patent protection of pharmaceutical products that are used in the treatment of a significant public health issue. The calculation of the level of suspension in valuing IP rights should not be very difficult for the suspending country

${ }^{402}$ Article 7, TRIPS Agreement. 
since the volume of pharmaceutical patent products on the market is normally available in databases ${ }^{403}$.

Not only an increase of the domestic welfare can be detected, but also the suspension in TRIPS concessions appears to be a good mechanism to stimulate IP rights holder lobbies to pressure the government to comply with DSB recommendations. Although, as previously stated, it is not easy to calculate the social welfare that results from a crossretaliation in TRIPS, this is an important element to be considered by the complainantmember seeking compliance.

\section{- $\quad$ Export Markets}

When calculating the level of suspension of concessions in cross-retaliation it is important to consider the availability of export markets to where the products produced under a suspension of intellectual property regime can be destined. A reason for this is that the value of intellectual property rights in the retaliating country is based on the total volume of sales that can be achieved by the right holder as a result of an exclusive position on the market ${ }^{404}$.

In an assessment of the level of suspension in cross-retaliation by the arbitrator in charge of a DSB recommendation, he/she should take into account the possibility of parallel exports - which would reduce the market share of IP right holders in countries to where they export their protected products.

Not by chance the panel noted, in the EC-Bananas III that an authorization of retaliation does not entitle other WTO members to derogate from their obligations under the TRIPS Agreement. So the temporary authorization granted to suspend concessions in TRIPS was just for Ecuador, and is not extendable to other members in order to reduce their TRIPS obligations ${ }^{405}$.

Nevertheless, an export to a non-WTO member could be possible, since the intellectual property right in question is not protected in the destined market. The protection

\footnotetext{
${ }^{403}$ See Abbott, 2009, p. 37. Abbott also addresses the subject of compulsory license, since it could be considered that if a public health concern exists, the suspending country could issue a compulsory license for the importation of generic pharmaceutical products - substitutes of the patented ones.

${ }^{404}$ Id., p. 24.
} 
(or not) in the importing market is always a concern that deserves attention, as intellectual property rights are territorial and the suspension in one territory does not mean suspension in another.

Thus, any profits resulting from the sales by manufactures/producers from the suspending member would be used to compute the losses of the intellectual property holders from the retaliated member - regardless of whether those IP holders have captured all the markets considered. Also, it does not matter the exact value of the intellectual property to the overall value of the goods (or services) that enjoy the suspended intellectual property right ${ }^{406}$.

One concern that crosses the present discussion is related to the exhaustion doctrine in intellectual property rights. According to this concept, the exhaustion of IP rights is triggered once a right holder sells or markets a good protected by its intellectual property rights. After the right holder has sold, it cannot prohibit the subsequent resale of the product, as his IP rights over the referred good are exhausted by the first sale.

Carvalho states that, in respect of industrial property - i.e. patents, trademarks, industrial designs and geographical indications -, the right is exhausted by the first introduction into the commercial circuit of the product incorporating the claimed invention, or bearing the protective distinctive signs. That is, of course, considering the right holder was the one to make available the product into the market (or with its consent) (07. $^{4}$

There is an issue in WTO law - which complicates the complexity of an eventual suspension of concessions for national legal systems, namely whether the exhaustion is applied only with respect to goods placed on the domestic market of the suspending country or whether legal actions of a government may also establish the ground for international exhaustion $^{408}$.

\footnotetext{
${ }^{405}$ See WT/DS27/ARB.

${ }^{406}$ See Basheer, 2009, p. 50-51. Concerning this subject, the author states that (relating to the US-Gambling dispute): "Antigua cannot be expected to micro-monitor the situation and track each possible instance of export to determine whether or not such exports are legal. It must therefore place the onus of legal compliance on the Antiguan entities that wish to use the suspended IP belonging to the defaulting state. If at all is a transgression in this regard, then the IP owner has a claim against the concerned operator and/or against the importer who brings such goods/service to another country and not against Antigua”. Id., p. 51.

${ }^{407}$ See Carvalho, 2010, p. 176-183.

${ }^{408}$ See Abbott, 2009, p. 24. Abbott states that "if an importing country follows the 'lawfully placed on the market' theory of exhaustion that does not require the consent of the IP holder, then a parallel IP right in an importing country would be exhausted under a suspension regime". Ibid.
} 
Thus this issue shall be addressed the question whether an importing country can rely on the doctrine of international exhaustion of IP rights to import goods produced under a regime of intellectual property suspension in the retaliating/exporting country. If that is considered possible, then, Ruse-Khan states that this would allow "any WTO member wishing to benefit from the suspension regime in the retaliating member to legalize the resale in its own territory of goods produced under suspension abroad" ${ }^{\prime 409}$.

Should legal actions, such as compulsory licensing, by a retaliating government indeed establish the ground for international exhaustion in relation to the goods brought on the market, then a spread of the potential welfare effects of the action would be significant. Lower prices and increasing availability of products to all the countries adopting such understand should be verified. On the other hand, the profits of the tight holder would be significantly undermined do to the consequent reduce in the sales of the original products ${ }^{410}$.

This section intended to shed some light over the main elements that shall be considered in a suspension of concessions under TRIPS Agreement context. With the short comments on the topics above it is possible to get the notion of how complicated a crossretaliation in TRIPS can be for the suspending member. It is the suspending member who has the burden of showing the calculations, the elements and IPRs that are going to be considered in an eventual cross-retaliation, and the way of doing so. Yet, in calculating the losses to intellectual property owners, not only the actual losses but also the potential ones may have to be accounted for ${ }^{411}$. Needless to say that for most WTO Members, carrying out all the details of the procedure maybe closely to impossible, either for the lack of legal and administrative capacity, or the lack of knowledge or economic/financial means to do so.

\subsection{Scope of Cross-Retaliation}

It is important to analyze whether the cross-retaliation in TRIPS may clarify the challenges and costs that are involved in such suspension of concessions. Although

\footnotetext{
${ }^{409}$ Ruse-Khan, 2008a, p. 355.

${ }^{410}$ Ibid. The author highlights that Article 6 of the TRIPS Agreement "leaves freedom to opt for national, regional or international exhaustion, the main issue at stake is whether TRIPS places any limitations on the type of acts in the exporting country which then allow the importing country to qualify the imports as legal under the doctrine of international exhaustion". Ibid.

${ }^{411}$ Subramanian; Watal, 2000, p. 407.
} 
suspension of concessions in TRIPS obligations can open opportunities for local industries to take advantage of possible suspensions of IP rights, cross-retaliating in TRIPS can also trigger complicated challenges to the suspending member.

It is true that, as argued before, retaliation in TRIPS can empower developing countries by giving them serious retaliatory strength which in turn can be genuinely welfare enhancing in a way that conventional retaliation is not ${ }^{412}$. Indeed, the suspension of intellectual property rights seems to be a surprisingly good opportunity for developing countries after the adoption of TRIPS compulsory standards.

As previously mentioned, countries with weak innovation sectors in general did not support or did not like the idea of adopting TRIPS during the Uruguay Round. On the other hand, countries with economies highly dependent on innovation were great supporters of a stronger enforcement system for intellectual property rights. Actually, as Howse et. al. explain, from a trade perspective, it is still not clear whether all countries shall be required to maintain the same level of intellectual property protection. At the same time that, for example, patent protection constitutes a form of monopoly to incentive innovation, it may also entail consumer welfare losses and may discourage diffusion of technology through imitation and adaptation by competitors, which are also valuable economic activities according to these authors ${ }^{413}$.

Therefore, it seems that continuous strength of IP protection increases the gap of the comparative advantage of developed countries, reducing the welfare of the developing ones. Although a global harmonization of IP protection facilitates trade negotiations in goods/services protected, a multilateral regime for the protection of intellectual property such as TRIPS should allow enough policy space to address the asymmetric reality of its members ${ }^{414}$.

Taking this scenario into consideration, the suspension of trade concessions on TRIPS obligations is broadly understood as an effective and sound mechanism to take advantage of developed countries' protected intellectual work and create positive welfare effects for the domestic market of the suspending developing country Member.

\footnotetext{
412 Id., p. 405.

413 Trebilcock; Howse, 2005, p. 397.

${ }^{414}$ See Trebilcock; Howse, 2005, p. 397-401 and Ruse-Kahn, 2008a, p. 338-339.
} 
Nevertheless, there are some challenges and costs that shall be considered in a cross-retaliation request. The present section is intended to address some clear detected issues that might complicate the job of the suspending country.

\subsubsection{Implementation under national law}

To enact a retaliatory action the suspending country has to have available mechanisms in its domestic legal system to enable it. So as not to infer in an illegal action, the domestic legal system shall be prepared to deal with a suspension on intellectual property rights in such a way as to promote the required flexibility that a cross-retaliation in TRIPS demands.

Unlike traditional retaliation in goods, cross-retaliation in TRIPS affects private rights. Indeed, intellectual property rights are private rights justiciable domestically in the domestic jurisdiction of the country granting them. As explained by Subramanian and Watal, once IPRs are conferred pursuant an act of a parliament in the domestic legislation their withdrawal can be challenged by the affected parties in the national courts as illegal or unconstitutional ${ }^{415}$.

Therefore, in order to make a suspension of intellectual property rights really possible (and more credible), the suspending Member needs to have a domestic legislation that covers such situation and granting it legal effect. Indeed, as stated by Salles: "the easier it is to run a given sanctions regime, the better - especially taking into account the temporary nature of such regime" ${ }^{416}$.

For that reason, the US has enacted a section to rule actions such as implementation of retaliatory measures in the domestic legislation. Section 301 of the Trade Act of 1974 authorizes the President to take any necessary and appropriate measure regarding

\footnotetext{
415 Subramanian; Watal, 2000, p. 408. The authors also note that in most countries the act of raising a tariff can be done just through an act from the executive while private IPRs are granted pursuant legislation and cannot be easily withdrawn. Ibid. Also, Abbott adds that "holders from IPRs from the country against which retaliation is proposed may object to 'discriminatory' changes to domestic IP rules on constitutional grounds". Abbott, 2009, p. 33. Moreover, Basso et. al. state that to some extent "the suppression of IPRs can be interpreted as an expropriation of rights and may thus generate problems vis-à-vis other international agreement”. Basso; Beas, 2005, p. 19.

${ }^{416}$ Salles, 2010, p. 301.
} 
international trade agreements to remove practices, acts or policies of a of a foreign government which might be discriminatory and restrictive to US $\operatorname{trade}^{417}$.

In the same line, and with specifically the intention of making it easier to implement measures for cross-retaliation, a deputy of Brazilian government - Paulo Teixeira - has presented a bill project (hereinafter PL) 1893/2007 which provides measures for suspension and dilution or dissolution of temporary protection of IPRs in Brazil for the breach of multilateral trade obligations by a foreign government within the $\mathrm{WTO}^{418}$.

In accordance with Article 3 of the project, the executive can suspend, in temporary terms, the compliance with obligations and other concessions referring to parts II, II and IV of the TRIPS Agreement and from the respective national legislation that deals with rights of intellectual property rights holders. More specifically it refers to the suspension of rights of IPRs holders, entrepreneurs, companies, natural people or residents in the country that does not comply with DSB recommendations in favor of Brazil ${ }^{419}$.

An amendment in the law of WTO Members is a basic issue and should be designed in order to make the implementation of cross-retaliation measures domestically feasible. Nevertheless, the great majority of government's members have not taken a first step in that direction and no developing country has provided measures for retaliation in the domestic IP legislation ${ }^{420}$. In fact, in the three cases when cross-retaliation was approved by the WTO, none of the suspending countries had a proper domestic legislation for that, and only Brazil presented a bill in order to facilitate and make the suspension of concessions in TRIPS more straightforward.

Regarding the issue of national legislation, one possible solution for countries is to amend the already existing rules and/or the national constitution (if that is the case) in order

\footnotetext{
${ }^{417}$ Section 301 available online at: < http://www.law.cornell.edu/uscode/html/uscode19/usc_sec_19_00002411-$--000-. h t m l>$.

418 PL 1893/2007 was presented on August $28^{\text {th }}$, 2007. The project is available online at: $<$ http://www.camara.gov.br/proposicoesWeb/fichadetramitacao?idProposicao=364818>.

419 Article 3, PL 1893/2007: “Art. 3rd O Poder Executivo Federal poderá suspender, temporariamente, o cumprimento das obrigações e outras concessões das Partes II, III, e IV do Acordo TRIPS e da respectiva legislação nacional que trata da mesma matéria no que se refere à proteção de direitos de propriedade intelectual de titulares, pessoas naturais nacionais ou domiciliadas em determinado Estado, ou pessoas jurídicas domiciliadas ou com estabelecimento efetivo em determinado Estado, quando este tenha deixado de implementar decisões e recomendações do Órgão de Solução de Controvérsias da OMC em detrimento de legítimos interesses comerciais do Estado brasileiro. Vais deixar a referencia toda em português?

${ }^{420}$ Subramanian and Watal refer to this situation as "voluntary unilateral disarmament". Subramanian; Watal, 2000, p. 415.
} 
to allow the government to suspend trade IP provisions under specific circumstances where cross-retaliation in TRIPS is permitted. There is no provision in the TRIPS or WTO Agreement prohibiting members to do so, thus amending domestic legislation could be an easier solution $^{421}$.

Also, as Abbott reminds us, there are mechanisms for eliminating or minimizing the requirements for new legislative action based upon pre-existing intellectual property legislation. Article 31 of the TRIPS Agreement regulates the use of the IP without the license of the right holder. Pursuant this Article, a government seeking to suspend TRIPS obligations could make use of this provision to grant compulsory licenses under the terms of its patent legislation, for example ${ }^{422}$.

\section{- Suspension of Enforcement}

The suspension on TRIPS obligations walks hand in hand with the suspension of enforcement of IP obligations in a certain territory. That is why it was decided to address a few words on the subject before proceeding to the next topic.

Considering the international scenario, and especially in the WTO environment, developed countries are normally the great demanders of the strongest intellectual property enforcement measures in foreign jurisdictions, whereas the developing countries normally take a defensive position ${ }^{423}$. That is a logical synergy, as developed countries concentrate the owners of the majority of the IP rights around the world and developed countries try to skip from further obligations concerning intellectual protection.

At this point Article 7 can be recalled from the TRIPS Agreement, pursuant to which the enforcement of intellectual property rights is exposed as a policy tool to balance rights and obligations and to promote the mutual advantage of producers and users of technological knowledge. Although this Article mentioned-in the previous section - describes broad objectives for protection and enforcement of IP rights, it seems that TRIPS makes clear

\footnotetext{
${ }^{421}$ See Whiteman, 2010, p. 205.

${ }^{422}$ See Abbott, 2009, p. 34.

${ }^{423}$ See Ruse-Khan, 2009, p. 2. See also Correa, 2009.
} 
that the exclusive rights granted to rights holders should, somehow, be combined with the promotion of social welfare.

Enforcement is current - and again - an instrument of pressure on the multilateral trade system. Enforcement used to be one of the main driving forces behind the conclusion of the TRIPS Agreement. Nowadays enforcement is an important subject of debate, as some countries do not seem satisfied with the minimum level of protection granted by TRIPS, and want more.

Pauwelyn highlights the fact that DSB panels have reached an understanding that TRIPS obligations in what refers to domestic intellectual property enforcement are generally limited to the existence of certain rules and procedures or providing enough legal ground to do things at the request of IP right holders. There is no requirement of substantive obligations ${ }^{424}$.

The TRIPS Agreement covers general obligations and remedies for domestic intellectual property enforcement regime in its part III ${ }^{425}$. Therefore, Article 41.1 states the following:

\begin{abstract}
Members shall ensure that enforcement procedures as specified in this Part are available under their law so as to permit effective action against any act of infringement of intellectual property rights covered by this Agreement, including expeditious remedies to prevent infringements and remedies which constitute a deterrent to further infringements. These procedures shall be applied in such a manner as to avoid the creation of barriers to legitimate trade and to provide for safeguards against their abuse ${ }^{426}$.
\end{abstract}

In general, part III of the TRIPS Agreement proposes/obligates that all WTO members to make civil infringements, effective remedies and border measures available in the

\footnotetext{
${ }^{424}$ Pauwelyn, 2010b, p. 32. Note that the dispute China-Measures Affecting the Protection and Enforcement of Intellectual Property Rights (WT/DS362/R), although it is not the first dispute focused on TRIPS enforcement rulings, it represents the first time a WTO panel focused primarily on the interpretation and implementation of the TRIPS enforcement provisions. About the dispute see Yu, 2011.

${ }^{425}$ See Ruse-Khan, 2010a, p. 3.

${ }^{426}$ Article 41.1, TRIPS Agreement.
} 
domestic legal system. Also, according to Article 61 of TRIPS, criminal sanctions shall be available in certain cases $^{427}$.

Abbott suggests two possible and effective ways for the suspension of intellectual property rights regarding enforcement, which could be (i) to suspend the right of IRP holders to initiate enforcement proceedings during the period of suspension in TRIPS and (ii) the suspension by limiting intellectual property rights where suspension of enforcement could be prescribed with respect to patents and regulatory data protection ${ }^{428}$. Regarding the limitation of IPRs, the author suggests that the retaliating member could make sure in domestic legislation that no injunctions would be available during the term of the suspension, and also that no compensation could be claimed concerning the suspension of the activities ${ }^{429}$.

\subsubsection{International Commitments}

Regarding international commitments and intellectual property conventions prior to TRIPS, Article 2 of the TRIPS Agreement states that:

1. In respect of Parts II, III and IV of this Agreement, Members shall comply with Articles 1 through 12, and Article 19, of the Paris Convention (1967).

2. Nothing in Parts I to IV of this Agreement shall derogate from existing obligations that Members may have to each other under the Paris Convention, the Berne Convention, the Rome Convention and the Treaty on Intellectual Property in Respect of Integrated Circuits ${ }^{430}$.

\footnotetext{
${ }^{427}$ Article 61 of TRIPS states that: "Members shall provide for criminal procedures and penalties to be applied at least in cases of willful trademark counterfeiting or copyright piracy on a commercial scale. Remedies available shall include imprisonment and/or monetary fines sufficient to provide a deterrent, consistently with the level of penalties applied for crimes of a corresponding gravity. In appropriate cases, remedies available shall also include the seizure, forfeiture and destruction of the infringing goods and of any materials and implements the predominant use of which has been in the commission of the offence. Members may provide for criminal procedures and penalties to be applied in other cases of infringement of intellectual property rights, in particular where they are committed willfully and on a commercial scale". See also Abbott, 2009, p. 32.

${ }^{428}$ Abbott, 2009, p, 32.

${ }^{429}$ Ibid.

${ }^{430}$ Article 2, TRIPS.
} 
When it comes to cross-retaliation on intellectual property rights, a fear that the actions of suspension of IPRs will implicate other international treaties on intellectual property can come into the discussion. However, most of the operative provisions of the Paris and Berne Conventions (WIPO administered conventions) have been incorporated by TRIPS. Also, in Article 2.2 it is understood that countries that are members of the Paris and/or the Berne Convention and of the WTO still continue to be bound by these instruments, separately ${ }^{431}$. Moreover, Pauwelyn explains that "any rights or obligations that WTO members may obtain under Parts V to VII do not necessarily have to give way to WIPO conventions, at least not pursuant to Art. 2.2"432.

One issue that could bring some complication regarding the Paris and Berne Convention is that both have provisions of national treatment in order to prevent discrimination among rights holders of the member countries. A right holder could try to invoke this provision to claim his/her right of national treatment is being violated in the domestic legislation of the suspending country ${ }^{433}$.

If there is a conflict between a WTO authorization to cross-retaliate and one of the WIPO conventions recourse shall be made to Article 30 of the Vienna Convention of the Law of the Treaties that establishes the following:

When all the parties to the earlier treaty are parties also to the later treaty is not terminated or suspended in operation under article 59, the earlier treaty applies only to the extent that its provisions are compatible with those of the later treaty ${ }^{434}$.

Pauwelyn further explains that pursuant the Vienna Convention since there is no apparent or inherent hierarchy between the sources of law, the latest expression of the State intent must prevail, which in the present case is the DSB authorization to suspension of TRIPS obligations ${ }^{435}$. Indeed, if it is the case of a dispute before the ICJ, in examining the settings of obligations of countries involved in a WTO dispute, the Court would find that the

\footnotetext{
${ }^{431}$ See Basheer, 2009, p. 60-61.

432 Pauwelyn, 2003, p. 346.

${ }^{433}$ Article 28 (1) of the Paris Convention and Article 33 (1) of the Berne Convention state that disputes between member nations shall be settled by the International Court of Justice (ICJ).

${ }^{434}$ Article 30, Vienna Convention of the Law of the Treaties.

${ }^{435}$ See Pauwelyn, 2003, p. 346.
} 
complaining and respondent countries had both expressly accepted the suspension of concessions regime prescribed by the $\mathrm{DSU}^{436}$.

A short comment is required to address the TRIPS-plus agreements, which refer to bilateral commitments that establish a higher standard of protection to intellectual property rights. Specially the US has negotiated and signed a number of free trade agreements with developing countries, which provide much stronger protection to IPRs ${ }^{437}$. The probable implication of a TRIPS-plus agreement is that developing countries may become unable to take advantage of a cross-retaliation proceeding against a WTO member with which the developing country has signed for stronger IP protection of the latter rights in its own domestic legislation ${ }^{438}$.

\subsection{Implementation Issues}

\subsubsection{Economic Feasibility: basic knowledge, domestic market size, costs of implementation}

One core challenge of suspending concessions in TRIPS for the suspending country relies in its own domestic economic conditions. For the retaliation procedure to achieve inducement of compliance and the production of social welfare (which are the basic raison d'être of retaliation) it must be economically feasible in the domestic market of the member aiming to retaliate.

The existence of three elements is considered to be important in the country that wishes to suspend concessions in TRIPS, namely: considerable domestic market size, basic know-how/knowledge and economic means to support the costs of implementing the retaliatory measures in its national context.

\footnotetext{
${ }^{436}$ See Abbott, 2009, p. 14. See also Basso; Beas, 2005, p. 20.

${ }^{437}$ Information about the US Free Trade Agreement is available online at: < http://www.ustr.gov/tradeagreements/free-trade-agreements $>$.

${ }^{438}$ See Whiteman, 2010, p. 204-205.
} 


\section{- $\quad$ Domestic Market Size}

The size of the domestic market as well as the consumer demand in the national territory are important issues to be taken into account in the decision of cross-retaliating in intellectual property rights. These factors are indeed crucial in the analyses of whether suspension in TRIPS can have a significant impact in the respondent country.

As previously mentioned, intellectual property rights are granted and protected on the basis of territoriality. That means that in order to be protected, these rights have to be claimed in the very country the rights holder wishes protection. Where cross-retaliation and domestic market size are concerned, the territoriality of IP rights are relevant in that the suspension of IP rights will only be worth for the retaliating country once there is significant consumer demand in its own territory.

Moreover, once any withdrawal of TRIPS obligations is actually limited to the national territory of the suspending WTO member, imports of goods produced under a suspension condition into other market members where the same goods are still protected by IP rights are, in principle, infringing. In other words, as explained by Ruse-Khan, if intellectual property rights are suspended, "the suspension can naturally only extend to IP rights granted by the national law and thus can only legalize domestic actions to protect IP for which obligations are suspended"439.

Therefore, considering the domestic market size, if it is a small market with no significant consumer demand, the potential economic loss by the retaliated country because of suspension on its IP rights on the suspending member market will be limited. Thus, neither the objectives of increasing social fare or induce compliance will be possibly accomplished.

\section{- Basic Knowledge}

A second element to be considered related to economic feasibility of crossretaliation if whether the suspending country has sufficient know-how and technical capability to take advantage of the period of suspension of concession. 
As the period of suspension is temporary, so as to make cross-retaliation in TRIPS really worthwhile, the suspending country shall have a fast scale production focused in the intellectual assets of the suspension in force ${ }^{440}$. Certainly, according to Ruse-Khan crossretaliation in intellectual property rights might enable (i) "domestic research institutions and industry to access, experiment with, utilize, improve and disseminate so far protected technology from the non-complying state" and (ii) "foster technological learning and development as well as domestic innovation through imitation" ${ }^{\text {441 }}$.

When the suspension includes technology intensive goods (like patents of pharmaceutical drugs) many WTO members may not be technologically proficient. Basheer gives a good example where he assumes that a huge pharmaceutical company has a small suspending country (such as Antigua) patent covering on of its pharmaceutical products. Even if a patent suspension is allowed by the country (Antigua) and the invention can freely be used, virtually no entities in the country have the technical means and capability to produce generics of the drug ${ }^{442}$.

If there is no basic local capacity and knowledge, local manufactures cannot respond to the gap created by the suspension of concessions in TRIPS. Given that the suspension is temporary, the scenario becomes worse and there is no way of taking advantage of a pharmaceutical patent protection, such as the one of the aforementioned example.

Therefore basic knowledge and capability to produce goods in a suspension of IP rights regime are elements that directly impact the ability to "meet the rationale for IP crossretaliation" and the achievement of increase of social welfare ${ }^{443}$. Indeed, as stated by Subramanian and Watal, "to be credible, retaliatory action must be lead to quick alternative supplies of production and must not create undue uncertainty for these alternative suppliers" ${ }^{444}$.

\footnotetext{
${ }^{439}$ See Ruse-Khan, 2008a, p. 349.

${ }^{440}$ Id., p. 352.

${ }^{441}$ Id, p. 337.

${ }^{442}$ See Basheer, 2009, p. 57. The author states that "one needs to strike a distinction between developing countries and technology proficient developing countries", as the "cross-retaliation tool may prove a stronger one in the hands of technologically proficient developing countries". Ibid.

${ }^{443}$ Ruse-Khan, 2008a, p. 353.
} 


\section{- Costs of Implementation}

Once a cross-retaliation procedure is approved, the retaliating country may have to invest a considerable amount of money in order to profit from the suspension of intellectual property rights. The manufacture of the desired IP goods belonging to the respondent country may even require investing in a whole new infrastructure for this purpose ${ }^{445}$.

Considering that the whole process is temporary, the costs shall gain a higher level of importance by the suspending country. Of course the costs depend on the type of intellectual asset that is going to be attacked. For example, making use of a suspension of a pharmaceutical patent suspension will cost much more investment than a 'simple' suspension of protection on copyrighted works, or the payment of royalties ${ }^{446}$.

One factor that could promote incentive for the suspending country to invest during the retaliation period is the prospect of a compulsory license. Indeed, although Article 31 of TRIPS makes several requirements for the issuing of a compulsory license, the Article also leaves enough flexibility for the country to determine the grounds on which a compulsory license can be issue.

Rightly, while Basheer states that "the prospect of a compulsory license at the end of the retaliation period offers a sufficient incentive to such entities to make investments in the first place" ${ }^{\prime 47}$, Subramanian and Watal agree that domestic legislation could specify that compulsory licenses will be granted in cases where foreign trade partners do not comply with WTO obligations affecting them ${ }^{448}$.

\subsubsection{Political Pressure}

Perhaps the main obstacle developing countries will have to actually implement a cross-retaliation measure is the political one. No doubt a suspending country wishing to

\footnotetext{
${ }^{444}$ Subramanian; Watal, 2000, p. 412.

${ }^{445}$ See Basheer, 2009, p. 51. The author refers to these costs as "sunk costs".

${ }^{446}$ Id., p. 52.

${ }^{447}$ Id., p. 55.

${ }^{448}$ Subramanian; Watal, 2000, p. 412.
} 
retaliate in TRIPS will have to face great pressure from the developed country government and other stakeholders ${ }^{449}$.

As Abbott explains, powerful intellectual property dependent industries have been able to persuade governments and the media for decades that any interference with intellectual property rights is tantamount to criminal intent. Moreover, IP-dependent industries are normally willing to spend huge amounts of money to invest in government lobbying and media propaganda campaigns ${ }^{450}$.

Indeed, a strong counter pressure may arise from the intent of cross-retaliating by the suspension of intellectual property rights. The suspending government shall be ready to face international criticism and internal pressure from the multinationals affected ${ }^{451}$.

\subsection{Does Cross-Retaliation in TRIPS addresses the basic issue of non-compliance?}

As has been discussed throughout the present study, suspension of concessions or other obligations under the TRIPS agreement in form of a cross-retaliation is very much considered by WTO scholars and professionals as an interesting alternative available to developing countries. Theoretically, at the same time as it enables increase of social welfare of the suspending country, the cross-retaliation in TRIPS can be very successful in causing harm to sensible sectors of the violator's industry.

The incentive to comply though cross-retaliation in TRIPS comes from the protests and public motion that IP-dependent industries are able to promote especially by lobbying in the domestic area of the country affected. Powerful industries of entertainment, pharmaceutical and chemical industries and, among others, information technology industries may protest against countermeasures affecting their intellectual property rights. The industries may stop receiving royalties from copyrighted works and/or patents for technology or pharmaceutical products implicating in loss of a great amount of money. Therefore it is logical that these industries may pressure the government violator and stimulate the withdrawal of the WTO-inconsistent measures.

\footnotetext{
${ }^{449}$ See Whiteman, 2010, p. 205.

${ }^{450}$ Abbott, 2009, p. 38.
} 
The cross-retaliation systematic is very clear in the context of the DSU. Many factors can induce compliance in this regard, although the reason why States shall be induced to comply when confronted by a cross-retaliation in TRIPS is not very obvious. In some cases the high amount of retaliation can be a compliance-inducing factor, while in other cases the limited value of countermeasures can be an incentive to compliance. Still, in some disputes the nature of the retaliatory measures - such as suspension of concession in TRIPS -, or the sector affected or even a number of domestic reasons can be compliance-inducing ${ }^{452}$.

Yet, to ensure a better result with the suspension of concessions or other obligations under the TRIPS Agreement two elements seem to be very important. The suspending country has to be capable of identifying the sectors of IP-industry from which they can take better advantage in terms of increase of their domestic social welfare but also, the suspending country has to be capable of identifying the strong private operators that will mobilize great pressure on the government of the violator ${ }^{453}$.

Regarding the aforementioned element, - the capability to identify the strong private IP operators -, it is submitted that the suspending State should have a minimum domestic building capacity and IP professionals that can guide the process of selecting the target intellectual property rights of the tight holders of the affected country. Not every WTO member can count on this expertise in their national body of professionals.

For the success of cross-retaliation in TRIPS, it is important to ensure that the suspending country has means to afford the necessary expenditures with implementing the suspension of concessions of intellectual property rights in their national territory. The suspending country should have more than just an appropriate preparation in its domestic legislation to enforce suspension of IP rights (and avoid judicial problems with right holders), it should also have financial resources to afford the costs of implementation of a suspension system and take advantage of the cross-retaliation.

As already discussed in the previous chapter, cross-retaliation is meant to be a temporary process. To take advantage of it, the suspending country should have means to

\footnotetext{
451 Ibid. Abbott in the same place also states that "the government might well prepare press releases and diplomatic replies in advance".

${ }^{452}$ See more on inducement of compliance in Shadikhodjaev, 2009, p 29-30.

${ }^{453}$ In that sense, Abbott reminds us that there are specific elements in the IP industry that may generate great political pressure in the affected country: "the principal proponents of the TRIPS Agreement were the originator pharmaceutical industry and the copyright/entertainment industry. These two sectors remain the most powerful political constituencies demanding strong IP protection". Abbott, 2009, p. 37.
} 
afford it. Taking as example the suspension of pharmaceutical patents, and highlighting that the suspension is temporary, the suspending country should have at least (i) basic prior knowhow in dealing with pharmaceutical patens and (ii) financial resources to expend on the research and production of the pharmaceutical product. The same is valid for copyrights. If, for instance, the suspension is based on not collecting royalties owed to a license owner, the suspending country should have structures already in place, such as legal or administrative control of a collecting righs society, to enforce the suspension and to control the possible massive spread of the information, in case digital information is affected.

Moreover, not only the suspending country should have financial means to afford the costs of implementing suspension of intellectual property rights, but also a considerable level of domestic demand for the products with suspended rights. To justify all the effort that is involved in the cross-retaliation in TRIPS - i.e. legal, financial and political efforts -, the domestic market should be relatively significant for the suspending country to take such action under the WTO. It should guarantee a level of financial return that would make the suspension of concessions and other TRIPS obligations worth it.

Other elements that have to be considered in choosing cross-retaliation in TRIPS are the possible complications with international investors and the political problems that may emerge.

International investors will be carefully monitoring a country carrying out a suspension on IP rights, and may look upon such a country with distrust for future investments. That could be especially serious for WTO Members heavily dependent on foreign investment. Therefore, it is an element that could considerably discourage a small economy member to carry on a cross-retaliation procedure.

A remark must be made regarding the probable international political pressure of the process. Normally, industries that invest in intellectual assets, which would be target by a suspending country are strong entertainment, pharmaceutical or information technology industries. Current IP rights are the most valuable asset in the market which means that these rights are very much in the eyes of the media. A suspending WTO Member should be aware that in threatening the suspension of intellectual property rights of powerful industries, the country will have to be prepared to deal with a strong public lobbying in the international media. Accusation of violations of IP rights may arise in the international media in order to pressure and tarnish the image of the suspending State in the international society. 
From all that was mentioned, it seems, then, that cross-retaliation in TRIPS would not work for every small and developing economy of the WTO. And, therefore, not every Member that eventually makes use of cross-retaliation in IP rights would be able to induce compliance of the defaulting country.

The inducement compliance in terms of cross-retaliation (and also in traditional retaliation) is totally connected with a credible threat from the suspending country. Although as showed in the previous section -, there are academics who do not consider that the capability for presenting a credible threat, or the economic asymmetry of the opponents elements that would induce compliance, there is a strong belief that these factors play an important role in the decision of the violator to comply.

As argued by Salles, this research concurs that "the very threat of sanctions is one factor that promotes compliance with WTO rules and rulings" ${ }^{\text {"454 }}$. Even though there are many other factors that could lead one country to breach with its WTO obligations to comply, it is not possible to dismiss the fact that the credible threat focuses mostly on the significant or insignificant loss of market access - depending on the complainant in the game - it will have its importance in the final decision of the defaulting country.

Taking into account the market importance of the complainant in relation to the respondent, this author understands that cross-retaliation in TRIPS addresses the issue of noncompliance when and if the suspending country has a significant level of importance to the market of the defaulting country. Adding to that assumption, it seems reasonable to state that not only the relatively importance of one country to the other has to be observed, but also the domestic conditions of the complaining country to take cross-retaliation measures in intellectual property rights.

As aforementioned, there are domestic market demand issues, implementation costs and technological knowledge issues that cannot be dismissed by the retaliating country. Even more challenging - maybe - is the political pressure that the retaliating country is likely to face in suspending IP rights of powerful multinationals right holders.

Thus, the answer to the question of whether cross-retaliation is a mechanism to induce compliance is 'yes'. But, the answer is 'yes' in limited situations only. Among all the factors and variables that were discussed in this section and throughout the dissertation, cross-

${ }^{454}$ Salles, 2010, p. 298. 
retaliation in TRIPS should be very successful if applied by an upper level economy developing country, such as Brazil, China or India. Such countries, apart from having financial resources to spend in the implementation costs of a suspension of IP rights protection, probably have sufficient means in their industrial structure to take full advantage of a suspension on patents (for example) in a manner that they could rapidly reproduce the generic version of the product, profiting from it during the suspension period. Such countries are able to increase social welfare in the domestic sphere and promote innovation and research in their domestic industry. Finally, such countries surely have a sufficient domestic demand to purchase the products resulting from the suspension in IP rights.

Cross-retaliation in TRIPS does not work for the small developing economies of the WTO and therefore is not a great instrument that would address and benefit all the developing members seeking compliance of powerful economies.

\subsection{Selected Cases: approved requests for IP cross-retaliation}

This section is dedicated to the analysis of the three WTO disputes whose request for cross-retaliation was approved. The disputes presented have a developing country in the complainant seat and developed countries as respondent. The disputes were organized chronologically.

\subsubsection{EC - Bananas III ${ }^{455}$}

\section{- Summary}

In this dispute several claims from different countries are involved, among which are Ecuador, the United States, Guatemala, Honduras and Mexico. All claimants, except for Ecuador had requested the conclusion of consultations with the EC regarding the bananas

\footnotetext{
${ }^{455}$ European Communities - Regime for the Importation, Sale and Distribution of Banana.
} 
issues on September 28, 1995 (WT/DS16). After Ecuador's accession to the WTO, the previous complainants requested further consultations with the EC on February 5, $1996^{456}$.

The plaintiffs informed that the regime of import, sale and distribution of bananas from the EC was inconsistent with Articles I, II, III, X, XI and XIII of GATT, and with the provisions of the Agreement on Procedures for the Import Licensing Procedures, the Agreement on Agriculture, the Agreement on Trade-Related Investment Measures - TRIMS and the General Agreement on Trade in Services - GATS.

On April 11, 1996 the above-mentioned plaintiffs requested the establishment of a special group (also referred to as Panel), which was then established on June 7, 1996 (which refers to the dispute EC-Bananas III). The special group concluded that the import regime for bananas from the EC, as well as the procedures for granting licenses for the importation of bananas in this regime, were incompatible with the GATT. The Panel further found that the exemption contained in the Lomé Convention ${ }^{457}$ is obviously inconsistent with Article XIII of the GATT - which is non-discriminatory treatment with regard to quantitative restrictions ${ }^{458}$ but not the incompatibilities arising from the system for granting licenses ${ }^{459}$.

On June 11, 1997, the EC notified its intention to appeal certain issues of law and legal interpretations developed by the Panel. The Appellate Body report was distributed to Members on 9 September 1997 confirming most of the conclusions of the Panel. Nonetheless the Appellate Body $(\mathrm{AB})$ report revoked the conclusions of the Panel in regard to the incompatibility with Article XIII of GATT where the latter mention that it was clear by the exemption on the Lomé Convention. Still the $\mathrm{AB}$ report also revoked the panel conclusion in

\footnotetext{
${ }^{456}$ WTO. WT/DS27. Available online at: < http://www.wto.org/english/tratop_e/dispu_e/cases_e/ds27_e.htm>.

${ }^{457}$ The Lomé Convention governs trade and cooperation between the EU and countries of Asia, the Caribbean and Pacific (ACP). The first Lomé Convention was signed in 1975 with the participation of 45 states in these regions and after the merger of the United Kingdom to the European Community. The Lomé Convention was signed in 1975 with the participation of 58 ACP countries. Following the first conventions, were signed the Lomé Convention III, 1984, attended by 65 ACP countries, and Lomé IV in 1989, the 68 countries which joined in 1989 and 70 countries in 1995. According to the latter, exports from CARICOM can join the European Union without paying taxes, the agreement also provides for special arrangements for bananas, rum, beef and cuckoo. The Cotonou Agreement (Cotonou, Benin, June 23, 2000) replaces the Lomé Convention and has a term of twenty years, during which it will be subject to review every five years. The agreement restructures the trade relations between the European Community and the countries of Asia, the Caribbean and the Pacific. More information available online at: <http://www.cepal.org/publicaciones/xml/9/10029/Porcap11-Globalizacion.pdf $>$.

${ }^{458}$ Article XIII.1, do GATT: "1. No prohibition or restriction shall be applied by any contracting party on the importation of any product of the territory of any other contracting party or on the exportation of any product destined for the territory of any other contracting party, unless the importation of the like product of all third countries or the exportation of the like product to all third countries is similarly prohibited or restricted".

${ }^{459}$ WTO. WT/DS27.
} 
regard to certain aspects of the system of granting licenses, which were contrary to Article $\mathrm{X}$ of GATT, and the Agreement of Import of Licenses Procedures ${ }^{460}$.

On 15 December 1998, the EC requested the establishment of a Panel, in accordance with paragraph 5 of Article 21 of the DSU, with the aim of determining that the application of the EC measures were deemed to be in compliance with the standards of WTO as that had not been questioned in accordance with appropriate procedures of the DSU. On December 18, 1998, Ecuador requested the re-establishment of the Panel that initially ruled on the dispute in order to examine whether the EC measures to implement the recommendations were compatible with the $\mathrm{WTO}^{461}$.

The Panels were established on January 18, 1999, and their reports were distributed on April 12, 1999 ${ }^{462}$. The Panel established at the request of the EC in accordance with paragraph 5 of Article 21 found that, since Ecuador was actually claiming on the compatibility with WTO rules of the measures adopted by the EC to implement the recommendations of the DSB, it could not agree with the EC that it could be assumed that EC was fulfilling the recommendations of the DSB. This report was never adopted by the DSB. On the other hand, the report distributed by the Panel established at the request of Ecuador, in accordance with Article 21.5 of the DSU, found that the implementing measures adopted by the EC to implement the recommendations of the DSB were not fully compatible with the obligations of EC in the WTO framework. This report was adopted on May 6, 1999.

On January 14, 1999 the US requested the DSB authorization to suspend the application of concessions to the EC value of 520 million dollars ${ }^{463}$. Before this request, the EC requested on January 29, 1999, the establishment of an arbitration procedure pursuant Article 22.6 of the DSU, questioning the level of suspension of concessions proposed by the $\mathrm{US}^{464}$. The arbitrators decided that the level of retaliation requested by the US was not

\footnotetext{
${ }^{460}$ WTO. WT/DS27.

${ }^{461}$ WTO. WT/DS27.

${ }^{462}$ At this stage, some members reserved their rights as third parties: Jamaica, Nicaragua, Colombia, Costa Rica, Côte d'Ivoire, Dominican Republic, Dominica, Saint Lucia, Saint Vincent and Mauricio. Ecuador and India have expressed their interest to third parties only on the request of the EC.

${ }^{463}$ See Article 22.2, DSU.

${ }^{464}$ Article 22.6, DSU: "When the situation described in paragraph 2 occurs, the DSB, upon request, shall grant authorization to suspend concessions or other obligations within 30 days of the expiry of the reasonable period of time unless the DSB decides by consensus to reject the request. However, if the Member concerned objects to the level of suspension proposed, or claims that the principles and procedures set forth in paragraph 3 have not been followed where a complaining party has requested authorization to suspend concessions or other obligations pursuant to paragraph 3(b) or (c), the matter shall be referred to arbitration. Such arbitration shall
} 
equivalent to the amount of nullification or impairment of benefits that this country had suffered as a consequence of the EC regime for banana imports, determining that the level of nullification suffered by the US was 191, 4 million dollars. The US retaliation occurred, with the approval of the DSB, within the given amount of nullification ${ }^{465}$.

On November 8, 1999, Ecuador requested authorization to suspend the application to the EC of concessions or other obligations - in accordance with Article 22:2 of the DSU related under the following agreements: TRIPS, GATS and GATT 1994. Just as the US, the EC requested arbitration pursuant Article 22.6 of the DSU. The amount was of 450 million dollars. The arbitrators ruled, in the report distributed on March $24^{\text {th }} 2000$, that the level of nullification or impairment suffered by Ecuador amounted to 201.6 million dollars a year and that Ecuador could request the DSB authorization to suspend concessions or other obligations within the GATT 1994 framework $^{466}$; within GATS framework with respect to commercial distribution; and to the extent that it was insufficient, within the framework of the TRIPS section of copyright and related rights (section 1), Article 14 - on protection of artists and performers, producers of phonograms and broadcasting organizations, geographical indications and industrial designs. On May 18, 2000, Ecuador was authorized to suspend concessions to the EC, as determined by the DSB.

On June 22, 2001, the EC notified an 'Understanding on Bananas between the EC and the US', and an 'Understanding on Bananas between the EC and Ecuador', which implied that the parties had reached an agreement - in the sense Article 3:6 of the DSU ${ }^{467}$ - and that both US and Ecuador to refrain from using their rights to suspend concessions. What happened is that both Ecuador and the US declared that the understandings were not mutually agreed solutions.

It is remarkable that Ecuador maintained its independence through the whole dispute, and did not accept the lead of the US in the retaliation procedure.

be carried out by the original panel, if members are available, or by an arbitrator appointed by the DirectorGeneral and shall be completed within 60 days after the date of expiry of the reasonable period of time. Concessions or other obligations shall not be suspended during the course of the arbitration".

${ }^{465}$ WTO. WT/DS27.

${ }^{466}$ Here the DSB excluded capital goods and primary products as inputs for manufacturing industries and development. WTO. WT/DS27.

${ }^{467}$ Article 3.6, DSU: "Mutually agreed solutions to matters formally raised under the consultation and dispute settlement provisions of the covered agreements shall be notified to the DSB and the relevant Councils and Committees, where any Member may raise any point relating thereto". 
More recently, and following the development of the compliance proceedings, the EC informed the DSB that it intended to bring itself into compliance with its recommendations and rulings on 9 January 2009, by modifying its scheduled tariff commitments on bananas through an agreement on the level of the new EC bound tariff duty with Latin American banana supplying countries pursuant to negotiations under Article XXVIII of the GATT ${ }^{468}$.

On 7 January 2010, the EC and Ecuador notified the DSB they had reached a mutually agreed solution so as to end the dispute. Previously, on 21 December 2009, the EC had reported in the DSB meeting it had initialed with Ecuador and a number of other Members the so-called Geneva Agreement on Trade in Bananas.

\section{- Cross-retaliation issues}

With regard to cross-retaliation proposed by Ecuador, the EC discussed the right of the member to request authorization to suspend concessions and other obligations under the TRIPS Agreement, since there was no inconsistency of the regime for bananas within this Agreement according to the reports of the panel and the Appellate Body. Ecuador claimed that its request was justified by Article 22.3 (c) of the DSU, because it was not practical or effective for it to suspend concessions or other obligations in areas where violations were found by the Panel and the Appellate Body.

Although the DSB accepted the arguments from Ecuador, the country had never exercised its right to apply countermeasures. This is explained by a very clear reason: it would be extremely detrimental to its domestic market and its international economic relations especially with the EC - whereas it would cause little or no damage to the EC.

Nonetheless, in this dispute the negotiators from Ecuador were original and the primary negotiators found room to promote such cross-retaliation under the DSU in order to, as stated by Smith, "maximize their leverage within the specific institutional framework of 
WTO rules" ${ }^{469}$. In fact, the DSU rules - some of which were being applied for the first time did enable Ecuador to bargain above its own economic weight in the WTO.

Rightly, Ecuador understood that suspending market-access concessions to the EC would be either useful or threatening. With relation to the world market, Ecuador imports small quantities considering a big variety of goods and its retaliation in tariff duties would not inflict political or economic pain on the EC. Moreover and maybe more concerning, the imports of Ecuador were conformed in a large extent of intermediate products vital to its own domestic industry ${ }^{470}$.

In terms of persuasion of the arbitrators, Ecuador was very diligent in showing that it was neither practical nor effective for its domestic economy to suspend concessions against EC goods and/or services, and that the circumstances where serious enough to justify a cross-retaliation procedure ${ }^{471}$.

Ecuador then focused its sanctions on EC members who impose more obstacles to liberalization i.e. France, Spain and United Kingdom. Also, Ecuador was very careful in choosing to restrict its targets to categories of intellectual property rights "which there was little or no technology transfer, so as not to jeopardize its access to valuable technologies" The chosen sectors of the TRIPS Agreement to have the rights suspended were the copyrights, geographical indications and industrial designs ${ }^{473}$.

The suspending member also proposed a differentiated system of limited and revocable licenses that would only be granted to domestic firms from Ecuador to violate intellectual property rights up to a defined level and only for the advantage of the national market. In this sense, the arbitrators stated that:

It is evident that an authorization by the DSB for Ecuador to suspend certain TRIPS obligations would concern Ecuador only. Such authorization does not exonerate any other WTO Member from abiding by its WTO obligations, including those under the TRIPS Agreement ${ }^{474}$.

\footnotetext{
${ }^{469}$ Smith, 2003, p. 2.

${ }^{470}$ In this sense, see Ethier, 2004, p. 455.

${ }^{471}$ See Article 22.3, DSU.

${ }^{472}$ Smith, 2003, p. 15.

${ }^{473}$ WTO. WT/DS27/54.
} 
It is said that, at the time, the threat from Ecuador was made concrete and the developing country was not bluffing. But the country did not go forward. According to Smith, officials from Ecuador could have considered the intrinsic risks of suspending concessions under TRIPS with a great concern that the action could discourage foreign investment ${ }^{475}$.

\subsubsection{US - Gambling ${ }^{476}$}

\section{- Summary}

In 2003, the complainant Antigua and Barbuda requested consultations to the DSB regarding US measures applied by its authorities, which affect the cross-border supply of gambling and betting services. In accordance with Antigua findings, the cumulative impact of central, regional and local US authorities had the aim to prevent supply of the abovementioned services from another WTO member to the US domestic market.

According to the complainant the US measures may be inconsistent with the US obligations under GATS - in particular Articles II, VI, VIII, XI, XVI and XVII. The panel was established on 21 July $2003^{477}$.

Approximately fifteen years later, on 10 November 2004 the Panel report was circulated to WTO members. In sum and most interesting, the Panel found that:

- Three US federal laws (the Wire Act, the Travel Act and the Illegal Gambling Business Act) and the provisions of four US state laws (those of Louisiana, Massachusetts, South Dakota and Utah) on their face, prohibit one, several or all means of delivery included in mode 1 of GATS (i.e. crossborder supply), contrary to the United States' specific market access commitments for gambling and betting services for mode 1 . Therefore, the United States failed to accord services and service suppliers of Antigua treatment no less favourable than that provided for under the terms, limitations and conditions agreed and specified in the US Schedule, contrary

\footnotetext{
${ }^{474}$ WTO. WT/DS27/ARB/ECU.

475 See Smith, 2003, p. 17.

${ }^{476}$ United States - Measures Affecting the Cross-Border Supply of Gambling and Betting Services. WTO. WT/DS285. Available online at: < http://www.wto.org/english/tratop_e/dispu_e/cases_e/ds285_e.htm>.

${ }^{477}$ At the opportunity, Canada, the EC, Mexico and Chinese Taipei reserved their third-party rights. On 23 July 2003, Japan reserved its third-party rights.
} 
to Article XVI:1 and Article XVI:2 of the GATS (i.e. concerning market access);

- The United States was not able to invoke successfully the GATS exceptions provisions. In this regard, the United States was not able to demonstrate that the Wire Act, the Travel Act and the Illegal Gambling Business Act are "necessary" under Articles XIV(a) and XIV(c) of the GATS (i.e. "exceptions" provisions, including for public morals) and are consistent with the requirements of the chapeau of Article XIV of the GATS $^{478}$.

On January 2005, both Antigua and the US decided to appeal on certain issues of law. On 7 April 2005 the report of the Appellate Body was circulated. For the purpose of this study it was relevant that the AB report (i) upheld the Panel's finding that the United States acts inconsistently with Article XVI:1 and sub-paragraphs (a) and (c) of Article XVI:2 by maintaining certain limitations on market access not specified in its Schedule and (ii) upheld the Panel's finding, albeit for different reasons, that the United States' Schedule includes a commitment to grant full market access in gambling and betting services.

The DSB adopted the panel and the Appellate Body report on 20 April 2005.

As the parties could not agree on what would be a reasonable period of time for implementation in accordance with Article 21.3(b) of the DSU, Antigua requested that the reasonable period of time be determined through binding arbitration pursuant to Article 21.3(c) of the DSU. On 19 August 2005, the Arbitrator designated for the arbitration pursuant Article 21.3(c) circulated his award to the members, determining that the reasonable period of time for implementation was 11 months and 2 weeks from 20 April 2005, expiring on 3 April $2006^{479}$.

As the parties disagreed as to whether the US consistently complied with the recommendations and rulings of the DSB, Antigua requested the establishment of a Panel under Article 21.5 of the Understanding, where China, EC and Japan reserved their rights as third parties. The panel was composed on 16 August 2006. On 30 March 2007, the panel report on Article 21.5 was circulated to WTO members and concluded that the US had failed to comply with the recommendations and rulings of the DSB. The panel report was adopted by WTO members on 22 May 2007.

\footnotetext{
${ }^{478}$ WTO. WT/DS285.

${ }^{479}$ Ibid.
} 
One month later, on 21 June 2007, the complainant requested authorization from the DSB to suspend the application of concessions and other obligations of Antigua to the US under the GATS and the TRIPS Agreement. On 21 December 2007 the arbitrator circulated its decision which determined that the annual level of nullification and impairments of benefits accruing to Antigua was US\$21 million and that the complainant may request authorization from the DSB to cross-retaliate under TRIPS at a level equivalent to the level of nullification and impairment.

\section{- Cross-retaliation issues}

The arbitrators accepted that in considering the relative economic and trade position of Antigua compared to the US, it would be extremely difficult for the complainant to induce compliance by suspending concessions under GATS. The relative poor expression of Antigua's market size and the probable imposition of extra costs on Antigua's consumers were taken in consideration by the arbitrators to allow cross-retaliation in TRIPS ${ }^{480}$.

As Antigua had to present facts to prove that the circumstances were serious enough - Article 22.3 (c) - the complainant showed basic figures in order to compare the disparity between population, size, exports and imports, and gross domestic product (GDP) of both countries. Also, Antigua demonstrated and argued about its limited natural resources, very limited arable land and the high dependence its economy has on tourism and associated services (hotels, retail trade, housing, transportation, restaurants and real estate). Finally, Antigua also highlighted its need to diversify the domestic economy and that is one reason why the country tries to develop trade in services, including trade in remote gambling ${ }^{481}$.

In its request to suspend TRIPS obligations, Antigua indicated that it intended to apply countermeasure in form of suspension of concession on (i) copyright and related rights; (ii) trademarks; (iii) industrial designs; (iv) patents and; (v) protection of undisclosed information ${ }^{482}$.

\footnotetext{
${ }^{480}$ See Abbott, 2009, p. 7.

${ }^{481}$ World Trade Organization. WT/DS285/ARB, P. 74.

${ }^{482}$ Id, p. 77.
} 
Although Antigua's request resulted in the permission of the DSB to suspend concessions in TRIPS on 21 December 2007, the country has not yet - at the closure of this research in December 2011 - requested authorization to proceed with the suspension according to Article 22.7 of the DSU ${ }^{483}$.

Nevertheless, the first obstacle to Antigua in order to actually put in practice a cross-retaliation procedure is the fact that Antigua has not enacted a proper domestic legislation that would enable and legalize the DSB authorization. As previously mentioned, national legislation is a basic instrument to make cross-retaliation feasible (and more credible). Also, due to the enormous economic asymmetry between the members there are concerns whether Antigua would really have any meaningful compliance leverage over the US. Abbott believes that what might have some importance to the US is the "threat that causes the US to be concerned about the precedent of TRIPS cross-retaliation more than the direct economic consequences" ${ }^{484}$.

\footnotetext{
${ }^{483}$ Article 22.7, DSU states the following: "The arbitrator acting pursuant to paragraph 6 shall not examine the nature of the concessions or other obligations to be suspended but shall determine whether the level of such suspension is equivalent to the level of nullification or impairment. The arbitrator may also determine if the proposed suspension of concessions or other obligations is allowed under the covered agreement. However, if the matter referred to arbitration includes a claim that the principles and procedures set forth in paragraph 3 have not been followed, the arbitrator shall examine that claim. In the event the arbitrator determines that those principles and procedures have not been followed, the complaining party shall apply them consistent with paragraph 3. The parties shall accept the arbitrator's decision as final and the parties concerned shall not seek a second arbitration. The DSB shall be informed promptly of the decision of the arbitrator and shall upon request, grant authorization to suspend concessions or other obligations where the request is consistent with the decision of the arbitrator, unless the DSB decides by consensus to reject the request".

${ }^{484}$ Abbott, 2009, p. 8. About the US-Gambling dispute, see also Mendel, 2010, p. 310-316. It is also interesting to take a look at the memorandum prepared by students of the Graduate Institute of International and Development Studies (IHEID) in Geneva, which discusses different practical models of implementation of a cross-retaliation procedure for Antigua. Basically, the memorandum suggests: (i) the enactment of a domestic piece of legislation allowing for suspension of WTO obligations; (ii) the creation of a website with the server in Antigua; (iii) the suspension of the payments of the royalties to the IP rights holders and; (iv) grant of licenses on a free basis. IHEID, 2009.
} 


\subsubsection{US - Cotton ${ }^{485}$}

\section{- Summary}

On 27 September 2002 Brazil went to the DSB to request consultations with the US regarding subsidies to US producers, users and/or exporters of upland cotton. The subsidies referred by Brazil were actionable and prohibited and the country also requested consultations regarding the legislation, regulations, statutory instruments and amendments which provide such subsidies, export credits, grants and any other prohibited assistance to US upland cotton industry ${ }^{486}$.

Brazil asserted that US legislation (lato sensu) was not consistent with the following provisions of the WTO law: Articles 5(c), 6.3(b), (c) and (d), 3.1(a) (including item (j) of the Illustrative List of Export Subsidies in Annex I), 3.1(b), and 3.2 of the Subsidies and Countervailing Measures (SCM) Agreement ${ }^{487}$; Articles 3.3, 7.1, 8, 9.1 and 10.1 of the Agreement on Agriculture ${ }^{488}$; and Article III:4 of GATT $1994^{489}$.

The Panel was established on 18 March $2003^{490}$. On 8 September 2004 the Panel report was circulated to the members. The main findings of the report were:

- agricultural export credit guarantees are subject to WTO export subsidy disciplines and three United States export credit guarantee programmes are prohibited export subsidies which have no Peace Clause protection and are in violation of those disciplines;

- the United States also grants several other prohibited subsidies in respect of cotton;

- United States' domestic support programmes in respect of cotton are not protected by the Peace Clause, and certain of these programmes result in

\footnotetext{
${ }^{485}$ Subsidies on Upland Cotton. Available online at:

$<$ http://www.wto.org/english/tratop_e/dispu_e/cases_e/ds267_e.htm>.

${ }^{486}$ WTO. WT/DS267.

${ }^{487}$ SCM Agreement is available at: < http://www.wto.org/english/docs_e/legal_e/24-scm_01_e.htm>.

${ }^{488}$ Agreement on Agriculture is available at: < http://www.wto.org/english/docs_e/legal_e/14-ag_01_e.htm>.

${ }^{489}$ Zimbabwe, India, Argentina and Canada requested to join the consultations.

${ }^{490}$ Argentina, Canada, China, Chinese Taipei, the EC, India, Pakistan, Venezuela and later Australia, Benin, Chad, New Zealand and Paraguay reserved their rights as third parties.
} 
serious prejudice to Brazil's interests in the form of price suppression in the world market ${ }^{491}$.

On 18 December 2004 the US notified its intention to appeal. The Appellate Body Report was circulated to the member on 3 March 2005. The AB agreed with the panel report that two challenge measures - production flexibility contract and direct payments - are related to the type of production undertaken after the base period and then do not refer to green box ${ }^{492}$ measures conforming fully to paragraph 6(b) of Annex 2 to the Agreement on Agriculture; and, therefore, are not exempt, by virtue of Article 13(a) (ii), from actions under Article XVI of GATT 1994 and Part III of the Subsidies and Countervailing Measures (SCM) Agreement.

Also, the $\mathrm{AB}$ upheld the Panel's findings in what refers to the challenged domestic support measures granted - between 1999 and 2002 - supported upland cotton in excess during the 1992 benchmark period and, therefore, these measures are not exempt, by virtue of Article 13(b) (ii), from actions under Article XVI:1 of the GATT 1994 and Part III of the SCM Agreement. Still, the Appellate Body Report in majority opinion upheld the panel's finding that Article 10.2 of the Agreement on Agriculture does not exempt export credit guarantees from the export subsidy disciplines in Article 10.1 of that Agreement. Finally, the AB report agrees with the Panel's finding in what concerns the US "export credit guarantee programmes at issue-GSM 102, GSM 103 and SCGP-constitute a per se export subsidy within the meaning of item (j) of the Illustrative List of Export Subsidies in Annex I of the SCM Agreement" ${ }^{\text {"493 }}$, upholding the Panel's findings that these export programmes are indeed export subsidies pursuant Article 3.1(a) of the SCM Agreement and are inconsistent with Articles 3.1(a) of the same Agreement ${ }^{494}$.

The DSB adopted both the Panel and the Appellate Body reports at its meeting on 21 March 2005. By the requests of both parties, the Director-General composed a compliancePpanel on 25 October 2006, whose report was circulated to the WTO members on 25 October 2006. Mainly, the report found that:

\footnotetext{
${ }^{491}$ WTO. WT/DS267.

${ }^{492}$ According to the WTO definition, green box refers to Domestic support for agriculture that is allowed without limits because it does not distort trade, or at most causes implies minimal distortion.

${ }^{493}$ For the US credit guarantee programmes for cotton, see $<$ http://www.cottonusa.org/>.

${ }^{494}$ WTO. WT/DS267.
} 
Regarding GSM 102 export credit guarantees issued after 1 July 2005 the United States acts inconsistently with Article 10.1 of the Agreement on Agriculture by applying export subsidies in a manner which results in the circumvention of US export subsidy commitments with respect to certain unscheduled products and certain scheduled products, and as a result acts inconsistently with Article 8 of the Agreement on Agriculture. Regarding GSM 102 export credit guarantees issued after 1 July 2005 also acts inconsistently with Articles 3.1(a) and 3.2 of the SCM Agreement by providing export subsidies to unscheduled products and by providing export subsidies to scheduled products in excess of the commitments of the United States under the Agreement on Agriculture. By acting inconsistently with Articles 10.1 and 8 of the Agreement on Agriculture and Articles 3.1(a) and 3.2 of the SCM Agreement the United States has failed to comply with the DSB recommendations and rulings. Specifically, the United States has failed to bring its measures into conformity with the Agreement on Agriculture and has failed "to withdraw the subsidy without delay" 495 .

Both parties appealed in 2008, and on 2 June 2008, the Appellate Body report was circulated to Members. The $\mathrm{AB}$ report found that the compliance panel failed to make an objective assessment of the matter - export credit guarantee programme - , pursuant Article 11 of the DSU, as it dismissed the import of the re-estimates data submitted by the US on the basis of internally inconsistent reasoning. On the other hand, the $\mathrm{AB}$ upheld the compliance Panel finding that the GSM 102 programme is not designed with the intention to cover its long term operating costs and losses and that the programme consists in an export subsidy within the meaning of Article 3.1(a) of the SCM Agreement and Article 10.1 of the Agreement on Agriculture.

Furthermore, the Appellate Body found that acting inconsistently with the SCM Agreement and the Agreement on Agriculture, the US had failed to comply with the DSB recommendations and rulings and had failed to take the appropriated steps to remove the adverse effects or to withdraw the subsidy in the reasonable period of time ${ }^{496}$.

Therefore, the $\mathrm{AB}$ recommended that the DSB request the US to bring the measures found to be inconsistent with the Agreement on Agriculture and the SCM Agreement, into conformity with its obligations under those Agreements.

495 Ibid. The compliance panel also found that once the measures taken by the US to comply with recommendations and rulings originally adopted by the DSB are inconsistent with the objections of the US under the covered agreement, the original recommendation and rulings remain valid.

${ }^{496}$ Article 7.8, SCM Agreement: Where a panel report or an Appellate Body report is adopted in which it is determined that any subsidy which has resulted in adverse effects to the interests of another Member within the meaning of Article 5, the Member granting or maintaining such subsidy shall take appropriate steps to remove the adverse effects or shall withdraw the subsidy". 
The DSB adopted the compliance panel and the Appellate Body reports on 20 June 2008.

Thus on 4 July 2005 Brazil requested authorization to suspend concessions or other obligations (i) under Article 4.10 of the SCM Agreement and Article 22.2 of the DSU; (ii) with regard to the actionable subsidies -whose reasonable period of time expired on 21 September 2005 -, Brazil requested for authorization to suspend concessions under Article 7.09 of the SCM Agreement and Article 22.2 of the DSU; (iii) with regard to the prohibited subsidies, on 5 July 2005 the parties jointly notified the DSB that they had agreed on the Agreed Procedures under Articles 21 and 22 of the DSU and Article 4 of the SCM Agreement ${ }^{497}$.

Regarding the dispute, the arbitrator decided that the complainant could: (i) with regard to the prohibited subsidies Brazil could request authorization to suspend concessions or other obligations under the Agreement on Trade in goods - Annex 1A - at the level not to exceed the value of US\$ 147.7 million for year 2006 or, for other years, the amount to be determined by the calculation methodology described in the arbitrator's decision; (ii) with respect to the actionable subsidies, Brazil could request authorization to suspend concessions or other obligations under the Agreement on Trade in goods - Annex $1 \mathrm{~A}-$ at the level not to exceed the value of US\$ 147.3 million annually ${ }^{498}$. On 6 November 2009, Brazil requested authorization from the DSB to suspend the application to the US of concessions or other obligations in conformity with the arbitrators' decisions. The authorization was granted on 19 November 2009.

In 2010, on March $8^{\text {th }}$, the complainant notified the DSB informing that it would suspend the application to the US of concessions or other obligations under the GATT 1994. Also, the member informed that it would also suspend concessions or other obligations under the TRIPS and/or the GATS Agreements ${ }^{499}$.

\footnotetext{
${ }^{497}$ WTO. WT/DS267.

${ }^{498}$ Ibid. Note that the arbitrators also determined that, "in the event that the total level of countermeasures that Brazil would be entitled to in a given year should increase to a level that would exceed a threshold described in the decisions, updated to account for the change in Brazil's total imports from the United States, then, Brazil would also be entitled to seek to suspend certain obligations under the TRIPS Agreement and/or the GATS with respect to any amount of permissible countermeasures applied in excess of that figure". Ibid.

${ }^{499}$ WTO. WT/DS267/43.
} 
Shortly after, as the parties engaged into negotiations with a view to reaching a mutually satisfactory solution, on 30 April 2010 Brazil informed the DSB that it would postpone the imposition of the countermeasures notified on March 2010.

Approximately four months later, on 25 August 2010, Brazil and the United States informed the DSB that they had concluded a Framework for a Mutually Agreed Solution for the Cotton Dispute in the World Trade Organization, setting out parameters for discussion on a solution with respect to domestic support programmes of the US to cotton upland ${ }^{500}$. According to the agreement of the countries, as long as the Framework is in force, Brazil will not retaliate against the US, as approved by the DSB.

\section{- Cross-retaliation issues}

Since the Brazilian government announced the intention to cross-retaliate in TRIPS the dispute gained a tremendous attention from the media all around the world. Not only because of the interest of several WTO members-cotton producers but also because unlike the previous cross-retaliation procedures approved by the DSB, this time the threat to retaliate came from a big and increasingly developing economy.

Even though the Brazilian government always tried to sustain the position that it did not wish to initiate a trade war, the country showed strength and ability in the WTO negotiations and affirmed that their only desire was to make the US respect the DSB and Appellate Body recommendations and rulings.

The first preliminary list of retaliation published by the Brazilian government Resolution 74/2009 - for public consultation of the domestic industries is from 6 November 2009. Although it does not mention cross-retaliation procedures, the list was enacted in case of an eventual need to apply countermeasures to US in case of non-compliance. In Article 3 of this Resolution, the Brazilian government stated that the countermeasures subject to the consultation would consist of the imposition of additional duty of up 100 percentage points above the rate of import duty applied to products to be be selected by the Brazilian Foreign

\footnotetext{
${ }^{500}$ See WT/DS267/45.
} 
Trade Chamber - in Portuguese Câmara de Comércio Exterior (CAMEX) $)^{501}$-, originating and proceeding from the US, without prejudice to the adoption of other modalities or the inclusions of other tariff codes, by the decision of CAMEX ${ }^{502}$.

After the public consultation, the list for the suspension of concessions under GATT 1994 was published by CAMEX through Resolution 15/2010, on 5 March 2010 ${ }^{503}$. The government fixed the rate of import duty for a number of products with the term of 365 days ${ }^{504}$.

One week later, on 12 March 2010, the Brazilian government presented the list for cross-retaliation for consultation in TRIPS (CAMEX Resolution 16/2010), which - definitely - made the US government pay more attention to the Brazilian move ${ }^{505}$. And Brazil prepared itself well enough to publish this list.

As previously mentioned, since 2007 Brazil has a bill - PL1893/2007 -, which seeks to establish a legislative framework for the suspension of TRIPS obligations and allow the executive power of the government to apply measures for suspension and dilution or dissolution of the temporary protection of intellectual property rights in Brazil for the breach of multilateral obligations by a foreign country within the $\mathrm{WTO}^{506}$.

When Brazil realized that the US did not intend to comply with DSB and AB recommendations and rulings, President Lula on 10 February 2010, moved forward with the domestic legislation for suspension of concessions in TRIPS and enacted a Provisional

\footnotetext{
${ }^{501}$ The CAMEX was created by Decree 4.732/2003. Pursuant its Article 1, CAMEX is aimed at the formulation, adoption, implementation and coordination of policies and activities related to foreign trade in goods and services, including tourism. Decree $4.732 / 2003$ is available online at: $<$ http://www.planalto.gov.br/ccivil_03/decreto/2003/D4732.htm>.

502 CAMEX Resolution 74/2009, with the first preliminary list of retaliation for public consultation is available online in Portuguese at: < http://www.mdic.gov.br/arquivos/dwnl_1257771150.pdf $>$. The list includes 222 products from the US that could suffer retaliation with tariff rates of more than 100 percent of the value when imported to Brazil.

${ }^{503}$ The list of goods corresponds to an amount of retaliation of USD 591 million. The remaining annual amount of retaliation to which Brazil is entitled - USD 238 million, which adds up to the total authorized value of USD 829 million - will be applied in the sectors of intellectual property and services.

${ }^{504}$ CAMEX Resolution 15/2010 is available online in Portuguese at: $<$ http://www.mdic.gov.br/arquivos/dwnl_1268063292.pdf $>$.

${ }^{505}$ CAMEX Resolution 16/2010 is available online in Portuguese at: $<$ http://www.mdic.gov.br/arquivos/dwnl_1268663608.pdf $>$.

${ }^{506}$ See the preamble of PL 1893/2007. Moreover, the project also envisages the suspension of TRIPS-plus rights. See also Salles, 2010.
} 
Measure - in Portuguese Medida Provisória 482/2011 ${ }^{507}$. The Medida Provisória 482/2011 provides for measures to suspend concessions or other obligations of the country on intellectual property rights and others, in cases of noncompliance with the obligations of the Agreement Establishing the WTO. This Provisional Measure was then converted in a Federal Legislation on 24 June 2010 - Law 12.270/2010

Among other interesting provisions, Article 6 presents a list of actions that shall be applied individually or cumulatively, through a CAMEX Resolution in relation to intellectual property rights:

- $\quad$ (i) postponement of protection from the date to be set by the executive power thereby reducing the term of protection, requests for ongoing protection of intellectual property;

(ii) subtracting the term of protection for a specified period at any time of its duration;

(iii) licensing of non-commercial public use, without authorization of the owner;

(iv) suspension of the exclusive right to prevent imports and the domestic market of goods that incorporate patent rights even if the imported good has not been placed in the external market directly by the holder of intellectual property rights or with his consent;

(v) increase or introduction of additional amounts due on the bodies or public entities for the execution of intellectual property rights, including their acquisition and maintenance;

(vi) temporarily blocking remittance of royalties or compensation on the exercise of intellectual property rights of national licensed or authorized within the national territory;

\footnotetext{
${ }^{507}$ In Brazilian Constitutional Law, a provisional measure is an act of proprietorship of the President, with the force of law without the participation of the legislative power, which will only be called to discuss it and approve it at a later date. The assumption of the Medida Provisória is urgency and importance, cumulatively.

508 Lei 12.270/2010 available online in Portuguese at: <http://www.planalto.gov.br/ccivil_03/_Ato20072010/2010/Lei/L12270.htm>.
} 

- $\quad$ (vii) the application of commercial rights to be deducted from the remuneration that you entitled the holder of intellectual property rights, or;
- $\quad$ (viii) the creation of mandatory registration for obtaining and maintaining intellectual property rights ${ }^{509}$.

Thus unlike the other WTO members which received the right to cross-retaliate under TRIPS but did not have a domestic legislation to support the suspension of intellectual property rights of IPRs holders, in legal terms Brazil is currently prepared for such an action, if necessary.

The list of suspension in intellectual property rights is contained in the CAMEX Resolution 16/2010, which established suspension on several kinds of patents, copyrights and trademarks.

A simulation made by Lakatos et.al. shows the welfare impacts of the retaliation plan of Brazil, isolating the trade retaliation effects from the IP cross-retaliation effects. The table of these authors is reproduced below and it estimates the welfare gain/loss from private consumption considering both types of proposed retaliation ${ }^{510}$.

\footnotetext{
${ }^{509}$ Article 6, Lei 12.270/2010.

${ }^{510}$ See Lakatos; Walmsley, 2011.
} 


\begin{tabular}{|c|c|c|c|c|}
\hline \multicolumn{5}{|c|}{ Volume Changes in Private Consumption (\$mil) } \\
\hline & \multicolumn{2}{|c|}{ Trade Retaliation } & \multicolumn{2}{|c|}{ IP Retaliation } \\
\hline & US & Brazil & $\mathbf{U S}$ & Brazil \\
\hline Agriculture & 0.05 & -0.45 & -1.06 & 1.38 \\
\hline $\begin{array}{l}\text { Vegetables, } \\
\text { fruits and nuts }\end{array}$ & 0.00 & -0.13 & -0.02 & 0.15 \\
\hline $\begin{array}{l}\text { Plant-Based } \\
\text { Fibers }\end{array}$ & 0.61 & -2.71 & -0.05 & 0.15 \\
\hline Mining & -0.01 & 0.00 & -0.01 & 0.00 \\
\hline Food products & -0.39 & -0.72 & -3.34 & 4.75 \\
\hline $\begin{array}{l}\text { Vegetable, oils } \\
\text { and fats }\end{array}$ & -0.06 & -0.25 & -0.13 & 1.16 \\
\hline Dairy products & -0.17 & -0.55 & -1.43 & 2.17 \\
\hline $\begin{array}{l}\text { Other } \\
\text { Agricultural } \\
\text { Products }\end{array}$ & -3.10 & .4 .03 & -5.84 & 9.20 \\
\hline $\begin{array}{l}\text { Beverages and } \\
\text { tobacco } \\
\text { products }\end{array}$ & -1.53 & -0.38 & -2.70 & 2.36 \\
\hline Textiles & -1.28 & -1.21 & -1.67 & 1.20 \\
\hline Wearing apparel & -4.71 & -1.73 & -4.59 & 3.10 \\
\hline Manufactures & -8.65 & -0.39 & -10.00 & 5.97 \\
\hline $\begin{array}{l}\text { Chemical, } \\
\text { rubber, plastic } \\
\text { products }\end{array}$ & -6.05 & -3.47 & -7.05 & 7.54 \\
\hline Metal products & -0.48 & -0.13 & -0.55 & 0.67 \\
\hline $\begin{array}{l}\text { Motor vehicles } \\
\text { and parts }\end{array}$ & -8.68 & -1.71 & -8.93 & 8.63 \\
\hline $\begin{array}{l}\text { Transport } \\
\text { equipment nec }\end{array}$ & -0.81 & -0.06 & -1.12 & 0.51 \\
\hline $\begin{array}{l}\text { Electronic } \\
\text { equipment }\end{array}$ & -3.78 & -1.18 & -3.18 & 4.24 \\
\hline $\begin{array}{l}\text { Machinery and } \\
\text { equipment nec. }\end{array}$ & -4.44 & -0.86 & -4.87 & 2.50 \\
\hline $\begin{array}{l}\text { Manufactures } \\
\text { nec. }\end{array}$ & -4.84 & -0.68 & -4.28 & 2.81 \\
\hline Royalty services & -0.06 & 0.01 & -0.05 & 5.12 \\
\hline $\begin{array}{l}\text { Other business } \\
\text { services }\end{array}$ & -1.03 & -0.78 & -3.19 & 19.97 \\
\hline Services & -52.98 & -3.20 & -171.53 & 88.03 \\
\hline Total & -102.39 & -24.59 & -235.59 & 171.63 \\
\hline
\end{tabular}

Table VI - Source: Lakatos; Walmsley, 2011. 
If private consumption is considered, Brazil has a negative impact if the country utilizes only trade retaliation - tariff duties - and a considerable positive impact in IP retaliation. The authors made other comparisons besides the private consumption. They also considered the volume changes in output and welfare decomposition of WTO members and overall multilateral trade ${ }^{511}$. The negative impact of trade retaliation and the positive impact of suspension of concession in intellectual property rights appear in every simulation. Therefore, Brazil cross-retaliating in TRIPS would be fundamental to produce a welfare impact in the domestic economy.

The threat of sanctions led to intense negotiations between Brazil and the US in the first semester of 2010 in order to find a mutual agreement and try to avoid the Brazilian cross-retaliation. In April 2010 both members presented a preliminary memorandum of understanding (MOU) regarding a fund for technical assistance and capacity building with respect to the cotton dispute identifying certain measures and actions that if respected by the US, would lead to the suspension of Brazil's threatened retaliation ${ }^{512}$.

Two months later, on 25 June 2010, Brazil and the US concluded the "Framework for a Mutually Agreed Solution to the Cotton Dispute in the World Trade Organization (WT/DS267)" "513. Basically, the Framework "sets out parameters for discussions on a solution with respect to domestic support programs for upland cotton in the United States, as well as a process of joint operation reviews as regards export credit guarantees under the program GSM-10"514. As a consequence of the Framework, Brazil had to suspend trade retaliation/cross-retaliation against the US.

In reality, neither Brazil nor the US really wished to enter into a trade war. Both countries would lose, and Brazil could even risk losing its access to the US market under the

\footnotetext{
${ }^{511}$ Id., p. 24-25.

512 The "Memorandum of Understanding between the Government of the United States of America and the Government of the Federative Republic of Brazil Regarding a Fund for Technical Assistance and Capacity Building with respect to the Cotton Dispute (WT/DS267) in the World Trade Organization" is available online at: < http://www.brazilcouncil.org/sites/default/files/MOUonaFundforTAandCB-Apr202010.pdf>.

${ }^{513}$ The "Framework for a Mutually Agreed Solution to the Cotton Dispute in the World Trade Organization (WT/DS267)" is available online at:

$<$ http://docsonline.wto.org/GEN_highLightParent.asp?qu=\%28\%40meta $\% 5 F S y m b o l+W T \% F C D S 267 \% F C \% 2$

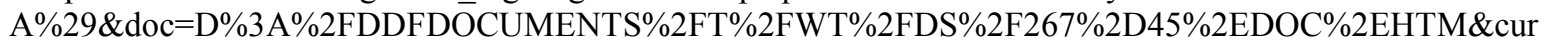
doc $=3 \&$ popTitle $=$ WT\%2FDS267\%2F45> .

${ }^{514}$ Id., p. 1. About the US-Cotton see also Schnepf, 2011.
} 
General System of Preferences ${ }^{515}$. Nevertheless, it has to be said that the threat from Brazil made the US government move. Probably more for political than for economic reasons, the two WTO members stepped back on the dispute and are trying to reach a reasonable solution for both sides. Currently, the US is paying Brazil to avoid retaliation. Following the DSU, that solution is not really the preferred outcome to settle a dispute, since the real aim of retaliation is to induce compliance.

\subsection{Concluding Remarks}

This chapter was intended to give an overall explanation about the intellectual property world, and how it interacts with the dispute settlement issues here discussed.

Mainly, the intention was to guide the research to what type of intellectual property rights promote a feasible possibility to an eventual cross-retaliation and to clarify the rationale of how to valuate these rights when the calculation is necessary considering the level of nullification and impairment.

Also, the research wishes to show some of the important challenges developing countries might confront if they opt for the suspension in TRIPS obligations. National implementation, international commitments, economic feasibility - i.e. basic knowledge, domestic market size, costs of implementation -, and the political pressure the countries may face are some of these issues.

As the mechanism of retaliation is an essential political instrument, it is believed that the above-mentioned elements do play a significant role in a successful cross-retaliation and/or in a credible threat of cross-retaliation. Indeed, that leads to the understanding that the suspension of concessions in TRIPS is not for every developing country. Only countries with sufficient domestic market size with a considerable consumer demand, with basic technology to take advantage of a suspension of patents (for example), and with strength to confront the lobbies from powerful IP-dependent industries are capable of taking advantage of a suspension of concessions in TRIPS.

\footnotetext{
${ }^{515}$ The General System of Preferences (GSP) is a system of exemption from the MFN principle that imposes that WTO member countries treat the imports of all other WTO member countries no worse than they treat the imports of their "most favored" trading partner. More information on the GSP of the US is available online at: $<$ http://www.ustr.gov/webfm_send/2880>.
} 
The three cases in which cross-retaliation was requested and approved by the DSB, despite the fact that none of them was put in practice, show the difficulty of the mechanism and the asymmetries of the two first complainants - Ecuador and Antigua - and Brazil. Brazil is by far more prepared to confront a strong potency like the US. Although the three threats made the respondents move forward in the direction of an agreement, probably Brazil was the only of the complainants that could really - economically speaking - put in force a cross-retaliation procedure in the domestic environment and take advantage of an increase of its social welfare.

\section{SUMMARY AND CONCLUSIONS}


International trade is one of the founding reasons of foreign relations among States. For centuries countries have been exchanging goods in order to export their own products and supply domestic demands importing from partners. More than ever before, multilateral trade is a key element of international connections among countries worldwide, and an indispensable factor for global economic growth.

In that sense, the establishment of the WTO is a remarkable historic event. Since 1995 multilateral trade has boosted economic growth. The WTO data estimates that between $\$ 109$ billion and $\$ 510$ billion were added to the world income as impact of the Uruguay Round finished in 1994. Empirical evidence is often amassed and demonstrates that lower trade barriers are good for all members of national economies. It allows a freer movement of goods, incentive of investment flows and permits a rapid transfer of technology and information across the world, promoting a great incentive to innovation.

The WTO rule-based system is a major contributor to the well-functioning of the multilateral trade. By submitting all the Members to the same rules, it truly reduces some inequalities. Relying on nondiscrimination-based principles, the WTO system constrains unilateral actions - especially from powerful members - and helps in the process of correcting the imbalances among countries.

This study addresses the question whether: taking into account the large economic imbalances of WTO Members and the difficulty of developing country members to induce compliance with WTO decisions, does cross-retaliation in TRIPS obligations contribute to a better effectiveness of the dispute settlement system where developing country Members are concerned?

In order to introduce the research theme - the multilateral trading system -, chapter two dealt with aspects and peculiarities of the multilateral trading system. Elements of international public law and international economic law used throughout the dissertation were presented in this section. A basic background of international economic law is provided in this chapter. Given the fact that the WTO is an international organization established by an international public law treaty, it was important to provide an overview of issues of State responsibility and the notion of what is currently understood by sovereignty of States in that chapter. Especially the principles of State responsibility are found to be important to explain the levels of noncompliance with WTO decisions, as indicated in the chapter four. 
In that context, this study pays special attention to the dispute settlement system with its strengths and weaknesses. There is no doubt that the DSU provisions succeeded - to a great extent - in promoting security and predictability in global trade relations. The considerable number of disputes dealt with by the WTO to date reveals, both the faith that member States have in the system, and the increase of its credibility. However, the dispute settlement system has inconsistencies and gaps that cannot be ignored provide the motivation for the present dissertation.

In chapter three the jurisdiction and procedures of the system was analyzed, with especial attention to the implementation of the Dispute Settlement Understanding. In that regard, the chapter describes the functioning of the WTO remedies, i.e. compensation and suspension of concessions and other obligations.

More specifically, the procedure of suspension of concessions and other obligations - such as retaliation in relation to goods or services other than those subject to the dispute, hence cross-retaliation - of intellectual property rights pursuant the TRIPS Agreement were analyzed in this study. Retaliation in this context refers to a mechanism normally available only when the complainant is a developing country, while the respondent is a powerful and developed member. Given the fact that retaliation is typically allowed only when traditional compensatory measures are thought to be neither practical nor effective, the analysis demonstrated that cross-retaliation is indeed an interesting option for some developing countries.

Preliminarily, in response to the problem posed by this dissertation, the analysis concluded that cross-retaliation in TRIPS can in fact contribute to a greater effectiveness of the dispute settlement system. Nevertheless, that conclusion has several caveats and should be approached with caution, as elaborated in chapter four.

Still, chapter three already addresses the potential difficulties that should be considered regarding the implementation phase of the DSU. In the implementation of WTO decisions, the concept of State sovereignty may come into play. Losing Members affected by DSB recommendations and rulings may be tempted to invoke State sovereignty as a shield of protection in order to circumvent compliance with the decisions. Notwithstanding, following the concepts of international public law, it is argued that (i) with the current interdependence among States there is no space for former concepts of absolute sovereignty of States; (ii) the WTO members voluntarily signed their participation and submission to the WTO laws and 
rulings, which shall be compulsorily respected: and (iii) Members shall be held responsible for the breaches of their international obligations and therefore shall be made to repair the damages caused by their violations.

Also worth noting is that in the same chapter the binding effect of the DSB recommendations and rulings is addressed. WTO Members have a pacta sunt servanda obligation according to which Members voluntarily agreed to compulsorily award a third party to settle their trade disputes. There seems to be a tendency to water-down the binding effect of the recommendations given by both the DSB and the Appellate Body. Although the term 'recommendation' can be understood to have a permissive connotation, the analysis of the present study support giving a full binding effect to the term 'recommendation'.

Moreover, in chapter three findings related to the asymmetry of WTO Members were presented, such as economic, political and social asymmetries that are direct and indirectly involved in the discussion. Even though multilateral trade does boost global economic growth, the differences that separate WTO players are considerable.

The study concludes that limited economic leverage and the lack of legal capacity to litigate in the WTO may be strong reasons constraining the use of the system by developing countries, especially where small economies are concerned. Those reasons, therefore, limit the Members concerned to take full advantage of the dispute settlement system.

However, even if these developing countries find means to circumvent the difficulties associated with entry to the system, other problems appear. In a later stage of the dispute, the economic and political asymmetries play an important role when it comes to the inducement of compliance with the recommendations and decision in the implementation phase. In considering a traditional compensatory measures, such as imposition of tariff duties, imposed by developing countries are usually counterproductive and will not cause any pressure to induce compliance. On the contrary, they will often bite the country imposing the sanction. In that scenario the possibility of cross-retaliation emerges as an attractive option for developing countries. Especially cross-retaliation in TRIPS obligations is found to be very effective in producing a credible threat to induce compliance by a recalcitrant Member.

This study concludes that compliance is not optional for WTO Members. Instead, compliance with WTO law and therefore with DSB recommendations and rulings is mandatory. 
With regards to the question of whether the economic asymmetry of members contributes to the noncompliance with recommendations and decisions, the study concluded that yes, it does. Although WTO Members can choose to comply with their obligations for many other reasons, this study assumes that a credible threat of retaliation does promote great level of incentive for compliance.

Finally the analysis in chapter three leads to the conclusion that a traditional compensatory mechanism pursuant the DSU goes in the opposite direction of raising standards of living and improving social welfare of WTO Members. Instead, retaliation resulting into additional tariff duties can produce extremely detrimental effects to international trade.

Chapter four focuses on intellectual property in order to test the central hypothesis of the research. In order to understand and analyze the effectiveness of suspension of concessions and other obligations pursuant the TRIPS Agreement as a retaliatory weapon, general concept of intellectual property were addressed. The first section offered an overview of the intellectual property world: agreements and types of IP rights. The study was extremely important in order to clarify each IP right singularities and functions and to preliminary select which intellectual property rights would be more suitable to promote a successful crossretaliation in TRIPS. After writing this section of the research, it was understood that in the case of an eventual cross-retaliation, the suspension on patents and copyrights may be the best and most practical option to stimulate both inducement of compliance and increase social welfare.

The first section offers an overview of the intellectual property world: international agreements and types of IP rights. This overview is necessary in order to clarify intellectual property right singularities and functions allowing the author to visualize and map the subject. This enables the selection of which intellectual property rights would be more suitable to promote a successful cross-retaliation in TRIPS. After testing IP rights as to their suitability as cross-retaliatory instruments, it is submitted that in the case of an eventual crossretaliation, the suspension on patents and copyrights could be the best and most feasible options in addressing both inducement of compliance and increase of social welfare.

Thus, it was logical to explore in this chapter how to establish the suspension on TRIPS obligations and to describe the basic rationale to calculate the level of retaliation. The level of cross-retaliation in TRIPS, according to DSU provisions, has to be equivalent and 
proportional to the level of nullification and impairment resulting from the issue at the center of the dispute before the DSB. Accordingly, the present study details four elements that have to be considered in the valuation of the cross-retaliation in IP, namely: equivalence, proportionality, social welfare and export markets. Although the arbitrators have the final world in matters of level of retaliation calculation, the suspending country has to be diligent in showing how to address equivalence and proportionality and, at the same time, indicate the increase of social welfare that the cross-retaliation may proportionately (provide) besides identifying the possible export markets.

Indeed, the retaliation in TRIPS presents challenges to be put in practice. This research tackles the ones that are most relevant to the suspending country. Therefore, the third section of chapter four set out to chart the challenges and costs - for the complainant - of suspending concessions and other obligations in TRIPS.

It can be concluded that the primary and most basic element that should be provided by the suspending country government is a national legislation on the topic.

In order to make cross-retaliation feasible, the suspending country has to provide for the enactment of a domestic legislation that enables the procedure. That is necessary so as not to infer an illegal action in the domestic jurisdiction. Unlike traditional compensatory measures, which deal with public rights - i.e. tariff duties -, cross-retaliation in TRIPS affects private rights that are subject to proprietary claims before national courts. Addressing the same nature of challenge, the dissertation also tackles the international commitments that may come into play.

The study concludes that the fear that actions of suspensions in TRIPS would be incompatible with other international treaties is quite unfounded. On the one hand, because TRIPS incorporated Paris and Berne Conventions, and on the other because undertaking WTO obligations does not necessarily imply the exclusion of WIPO conventions and commitments. The systems work together (as a whole or incrementally).

In addressing the economic feasibility of suspending concessions in TRIPS, the study covers the key challenges to the procedural requirement. Most of the WTO Members do not have economic conditions to proceed with a cross-retaliation. And for cross-retaliation to achieve the goals of inducement of compliance and social welfare increase, the developing country suspending concessions in TRIPS has to have considerable economic means to make the procedure feasible. 
Basically, this dissertation concludes that the suspending country has to have (i) a considerable domestic market size; (ii) basic knowledge; and (iii) sufficient means to afford the costs of retaliation.

First, the size of the domestic market matters since the country has to have sufficient product or service-related demand to justify and pay for the investments to implement the benefits of suspending IP rights. Second, if the suspending country does not pursue enough know-how and means to take advantage of the suspension of a patent (for example) the cross-retaliation produces no effect. Third, implementing the measures of crossretaliation in the suspending country may represent considerably high investments in the domestic structure in order to profit from the suspension of intellectual property rights.

Further challenges of a more political nature are covered in the third section of chapter four. It is argued that the main obstacle to implement cross-retaliatory measures for developing countries may be the political pressure from governments and stakeholders of developed countries. Powerful IP-dependent industries can be expected to lobby intensively to tarnish the reputation of the developing country trying to put in force cross-retaliatory measures.

In order to see how all the elements work in practice, the last section of chapter four reviews the three cases where requests for cross-retaliation were made and approved by the WTO, namely: the EC-Bananas III, the US-Gambling and the US-Upland Cotton decisions. The section shows the procedural difficulties of putting the measures into practices as evidenced by the fact that these disputes did not yield practical approval. Also, the analysis in this section confirmed the assumptions made in relation to the challenges and difficulties aforementioned and showed that within the group of developing country complainants (Ecuador, Antigua and Brazil) only Brazil could really put in force a credible threat of the proposed cross-retaliation in TRIPS.

In light of the ambition to strive towards a more balanced multilateral trade, the study nevertheless concludes that:

The mandatory observation of trade rules is the primary requirement for fair play. Cross-retaliation in TRIPS can function as a development instrument through the promotion of the dissemination of information, the incentive of innovation and therefore, through the promotion of social welfare increase. 
In view of the above, the final conclusions of this study on the cross-retaliation in TRIPS and compliance issues at the WTO, specially focusing on the situation of Member asymmetries in the implementation phase can be summarized as follows:

(i) The emergence of the WTO and its dispute settlement system delivered predictability and legal security in the multilateral trade arena;

(ii) As members of an international organization, States (and Members) are liable pursuant International Public Law rules for their attitudes and breach of obligations regarding the WTO. This includes the breach of the obligation to comply with the DSB and Appellate Body decisions;

(iii) Adopted DSB rulings and recommendations are binding and must be observed by WTO Members;

(iv) The asymmetries of WTO Members as described in the dissertation can be translated into huge differences regarding GDP, market share, technological means, innovation and political power;

(v) Many WTO Members do not enjoy the benefits of the dispute settlement system as they cannot gather financial resources to improve their own legal capacity to ligate;

(vi) Although the WTO presents a high percentage of compliance within its dispute settlement decisions, the number does not indicate only cases of full compliance as it considers partial compliance of decisions and negotiations among Members instead of compliance. However, every instance of noncompliance is very problematic to the multilateral trade system;

(vii) The mechanism of retaliation is a political instrument and as such, being capable of posing a credible threat to the violator, is essential for the system to work;

(viii) In considering cross-retaliation, the suspension on IP rights is interesting, because it affects sensible and powerful sectors of IP-dependent industries, mostly concentrated in developed countries;

(ix) National implementation, international commitments, economic feasibility - i.e. domestic market size, basic knowledge, costs of implementation -, and the political pressure 
are elements that should be taken in consideration by the developing country wishing to crossretaliate;

(x) The suspension of concessions in TRIPS is not suitable for every developing country. Only countries with sufficient domestic market size with a considerable consumer demand, with a developed technology base, and with strength to confront the lobbies from powerful IP-dependent industries are capable of taking advantage of cross-retaliation in TRIPS;

(xi) As not all the developing members are capable of delivering a credible threat of cross-retaliation, collective retaliation could be a solution for the lack of bargaining power of smaller economies;

(xii) A credible threat of cross-retaliation in TRIPS does instill in the WTO Members a certain level of persuasion for compliance with decisions and recommendations of the DSB and $\mathrm{AB}$. 


\section{SAMENVATTING EN CONCLUSIES}

Internationale handel staat onder andere aan de basis van internationale betrekkingen tussen landen. Over de eeuwen heen hebben landen goederen verhandeld door eigen producten te exporteren en van handelspartners te importeren om the kunnen voldoen aan interne vraag. Meer dan ooit tevoren is multilaterale handel een onmisbare schakel in internationale contacten, en vormt het een belangrijke factor voor internationale economische groei.

In dit kader is het ontstaan van de Wereld Handelsorganisatie (WTO) van historische betekenis. Sinds 1995 heeft het de multilaterale handel doen toenemen. De WTO schat dat als gevolg van de in 1994 afgesloten Uruguay ronde van onderhandelingen wereldwijd het inkomen tussen de 109 en 510 biljoen Amerikaanse dollars is toegenomen. Onderzoek toont aan dat lagere douanetarieven positief zijn voor de nationale economieën van alle WTO leden. Reductie van handelsbarrières draagt bij aan vrijer verkeer van goederen, het doen van investeringen en aan snelle overdracht van technologie en informatie.

De WTO wet- en regelgeving levert een substantiële bijdrage aan het functioneren van de multilaterale handel. Door alle Lidstaten aan dezelfde regels te onderwerpen, wordt een aantal ongelijkheden gereduceerd. Door uit te gaan van een non-discriminatie principes, beperkt het WTO systeem eenzijdig handelen - vooral van machtige Lidstaten - en helpt in het herstel van disbalans tussen landen.

- $\quad$ Deze studie behandelt de vraag of: met in acht neming van het feit dat er grote economische verschillen tussen WTO Lidstaten bestaan en dat het afdwingen van nakoming van WTO uitspraken en normen voor ontwikkelingslanden problemen oplevert, kruislingse vergelding met betrekking tot opschorting van TRIPS verplichtingen bij draagt aan een verhoogde efficiency van het conflictbeslechtingssysteem wanneer ontwikkelingslanden betrokken zijn.

Ter introductie van dit onderzoeksthema worden in hoofdstuk twee aspecten en bijzondere eigenschappen van het multilaterale handelssysteem behandeld. Onderdelen van het internationaal publiekrecht en internationaal economisch recht, waaraan in het gehele werk aan gerefereerd wordt, worden hier geïntroduceerd. In dit hoofdstuk wordt een basale introductie in het internationaal economisch recht gepresenteerd. Gezien het feit dat de WTO 
als internationale organisatie is gevestigd bij internationaal publiekrechtelijk verdrag, was het belangrijk in dit hoofdstuk een overzicht te verschaffen van principes van statelijke verantwoordelijkheid en datgene wat heden ten dage wordt verstaan onder soevereiniteit van staten. Met name het begrip statelijke verantwoordelijkheid blijkt, zoals later aangegeven in hoofdstuk vier, belangrijk te zijn voor de verklaring van de niveaus van niet nakoming met WTO uitspraken.

In deze context besteedt deze studie bijzondere aandacht aan de sterkten en zwakten van het geschillenbeslechtingssysteem. Het staat buiten kijf dat de bepalingen van het 'Dispute Settlement Understanding' (DSU) in grote mate bepalend zijn voor het bewerkstelligen van de veiligheid en voorspelbaarheid in globale handelsrelaties. Het aanzienlijk aantal geschillen dat door de WTO tot op heden is behandeld toont zowel het vertrouwen van de Lidstaten in het system, en anderzijds de toenemende geloofwaardig erin aan. Het systeem ken echter ook onmiskenbare tegenstrijdigheden en lacunes welke niet terzijde kunnen worden geschoven en die de aanleiding zijn voor de huidige studie.

In hoofdstuk drie zij de jurisdictie en procedures van het systeem geanalyseerd, waarbij met name aandacht is besteed aan de implementatie van het DSU. In dit opzicht beschrijft het hoofdstuk het functioneren van WTO remedies, zoals compensatie en het opschorten van concessies of andere verplichtingen. Meer bepaald, de procedure van het opschorten van concessies en andere verplichtingen -zoals vergelding met betrekking tot andere goederen of diensten dan die onderdeel uitmaken van het geschil, dus kruislingse vergelding- van intellectuele eigendomsrechten voortvloeiend uit het TRIPS Verdrag zijn in deze studie geanalyseerd. In deze context is kruislingse vergelding een mechanisme dat normalerwijze alleen beschikbaar is wanneer de eiser een ontwikkelingsland is, terwijl de gedaagde een machtig en ontwikkeld land is. Gezien het feit dat kruislingse vergelding alleen dan beschikbaar is wanneer traditionele compensatoire maatregelen niet als praktisch of effectief worden gezien, kan uit de analyse worden opgemaakt dat kruislingse vergelding inderdaad een interessante optie is voor ontwikkelingslanden.

- In licht van de onderzoeksvraag die ten grondslag ligt aan deze studie, leidt de analyse dan ook tot de primaire conclusie dat kruislingse vergelding ten aanzien van TRIPS verplichtingen bij kan dragen tot een grotere effectiviteit van het geschillenbeslechtingssysteem. De conclusie moet echter voorzien worden van een aantal kwalificaties en caveats, zoals in hoofdstuk vier verder uitgewerkt. 
Nochtans worden in hoofdstuk drie reeds de mogelijke moeilijkheden behandeld welke van belang zijn in de implementatie fase van de DSU. Bij het implementeren van WTO beslissingen komt het concept van soevereiniteit van naties om de hoek kijken. Verliezende Leden die door de aanbevelingen en uitspraken van de Dispute Settlement Board (DSB) worden getroffen zouden soevereiniteit van naties kunnen inroepen om onder hun nakomingsverplichting uit te komen. Desalniettemin moet op basis van het internationaal publiekrecht worden aangenomen dat: (i) in het kader van de onderlinge afhankelijkheid van Staten geen plaats meer is voor het oude concept van absolute soevereiniteit van Naties; (ii) de WTO Leden zich vrijwillig door toetreding onderwerpen aan het WTO recht en uitspraken, welke binden zijn en moeten worden nagekomen; en (iii) Leden verantwoordelijk zijn voor het niet nakomen van hun internationale verplichtingen, waardoor zij ook verplicht zijn in geval van niet-nakoming schade te vergoeden.

Het moet ook worden gezegd dat in hetzelfde hoofdstuk het bindend karakter van de DSB aanbevelingen en uitspraken wordt behandeld. WTO Leden hebben een pacta sunt servanda verplichting, waaronder de Leden vrijwillig hebben besloten tot het verlenen van een automatische compensatie voor een derde partij om handelsgeschillen te beslechten. Er lijkt een tendens te bestaan om het bindend karakter van zowel DSB en Appellate Body (AB) aanbevelingen te veronachtzamen.

Hoewel de notie 'aanbeveling' een permissief karakter lijkt te hebben, geeft de analyse in deze studie aanleiding aan de term 'aanbeveling' een volledig bindend karakter toe te kennen.

Vervolgens zijn in hoofdstuk drie bevindingen met betrekking tot economische asymmetrie van WTO Leden gepresenteerd, zoals economische, politieke en sociale asymmetrie die van direct belang is voor de discussie. Ook al jaagt multilateraal handel globale economische groei aan, blijven de verschillen tussen onderlinge WTO Leden substantieel.

- De studie concludeert dat beperkt economisch gewicht en een gebrek aan juridische capaciteit om WTO geschillen aan te spannen zwaarwegende reden zijn die het gebruik van het systeem door ontwikkelingslanden, met name die met een kleine economie, beperkt. Deze redenen staan derhalve in de weg aan de mogelijkheid van dit soort Leden om effectief gebruik te kunnen maken van het geschillenbeslechtingssysteem.

Zelfs wanneer deze ontwikkelingslanden de middelen vinden om de moeilijkheden met betrekking tot het verwerven van toegang tot het systeem te overwinnen, doemen er andere 
problemen op. In een later stadium van het geschil speelt namelijk de economische en politieke asymmetrie op wanneer het aan komt op het afdwingen van nakoming in de implementatiefase van de aanbevelingen en de uitspraak. Goed beschouwd zijn traditionele compensatoire maatregelen, zoals het opleggen van douanetarieven, opgelegd door ontwikkelingslanden doorgaans contraproductief en er gaat geen druk vanuit om nakoming af te dwingen. In tegendeel, deze maatregelen schaden doorgaans het land dat de sanctie op wenst te leggen. In dat geval biedt de mogelijkheid van kruislingse vergelding een aantrekkelijke mogelijkheid voor ontwikkelingslanden. Met name kruislingse vergelding met betrekking tot TRIPS verplichtingen blijkt een zeer effectief wapen te zijn om een weerspannig Lid tot nakoming te bewegen.

- De studie concludeert dat nakoming niet optioneel is voor WTO Leden. Integendeel, nakoming met WTO recht en DSB aanbevelingen en uitspraken is verplicht.

- Waar het de vraag betreft of economische asymmetrie tussen Leden bij draagt aan niet-nakoming van aanbevelingen en uitspraken, is de conclusie van de studie bevestigend. Hoewel WTO Leden ervoor kunnen kiezen om hun verplichtingen op basis van allerlei andere redenen na te komen, neemt deze studie het standpunt in dat een geloofwaardige dreiging van vergelding een grotere incentive voor nakoming promoot.

- Ten slotte leidt de analyse in hoofdstuk drie tot de conclusie dat een traditioneel mechanisme van compensatoire mechanisme van de DSU het tegenovergestelde bewerkstelligd van het doel van verhoging van levensstandaard en sociaal nut in WTO Leden. In tegendeel, vergelding resulterend in hogere douanetarieven kunnen zeer schadelijke hebben voor internationale handel.

Hoofdstuk vier gaat in op intellectuele eigendom om de centrale hypothese van dit onderzoek te testen. Om de effectiviteit van de opschorting van concessies en andere verplichtingen onder het TRIPS Verdrag te begrijpen en analyseren, zijn allereerst algemene concepten van intellectuele eigendom (IE) beschreven. Het eerste deel geeft een overzicht van de (internationale) wereld van intellectuele eigendom: internationale verdragen en soorten IE rechten. Dit overzicht is noodzakelijk om functies en eigenschappen van afzonderlijke intellectuele eigendomsrechten te verhelderen, hetgeen de auteur in staat stelde om het veld te overzien en in kaart te brengen. Dit maakt het mogelijk de intellectuele eigendomsrechten te 
selecteren die zich het best lenen voor kruislingse vergelding in TRIPS. Na IE rechten te hebben getoetst op hun geschiktheid als kruislings vergeldingsinstrument, kan worden opgeworpen dat in geval van een eventuele kruislingse vergelding, de opschorting van octrooi- en auteursrechten zich het best lenen voor het bewerkstelligen van de doelstellingen van zowel nakoming alsook verhoging van het sociaal nut.

Het was derhalve logisch om in dit hoofdstuk na te gaan hoe de opschorting van TRIPS verplichtingen vast te stellen en de ratio te beschrijven voor de berekening van de omvang van de vergelding. De omvang van de kruislingse vergelding in TRIPS moet, volgens de bepalingen van de DSU, gelijk en proportioneel zijn aan de omvang van het verlies en handelsbelemmering die het gevolg is van het geschil dat bij de DSB aanhangig is. De huidige studie onderscheidt daarom vier elementen die in aanmerking moeten worden genomen in de berekening van kruislingse vergelding in IE, namelijk: equivalentie, proportionaliteit, sociaal nut, en export markten. Hoewel de arbiters het laatste woord hebben waar het de vaststelling en berekening van de omvang van de vergelding, moet het opschortende land zorgvuldig aantonen hoe equivalentie en proportionaliteit, en tegelijkertijd een verhoging in het sociale nut dat kruislingse vergelding op proportionele wijze bewerkstelligt, kan worden bereikt en moet het de mogelijke export markten identificeren. De vergelding in TRIPS is niet makkelijk in praktijk te brengen en er zijn zekere uitdagingen. Dit onderzoek gaat in op die uitdagingen die het meest relevant zijn voor het land dat verplichtingen op wenst te schorten. In het derde deel van hoofdstuk vier worden de uitdagingen en kosten -voor de klager- van het opschorten van concessies en verplichtingen onder TRIPS in kaart gebracht.

- $\quad$ Geconcludeerd kan worden dat de primaire en essentiële voorwaarde voor opschorting die door de nationale wetgever moet worden geschapen gelegen is in nationale wetgeving over dit onderwerp.

Om kruislingse vergelding mogelijk te maken moet het opschortende land voorzien in nationale wetgeving die een dergelijke procedure mogelijk maakt. Dit is noodzakelijk om onwettige maatregelen in de nationale rechtsorde te voorkomen. In tegenstelling tot traditionele compensatoire maatregelen welke betrekking hebben op publieke rechten douanerechten-, worden in geval van kruislingse vergelding in TRIPS private rechten getroffen, welke als eigendomsrechten voor de nationale gerechten kunnen worden geclaimd. In hetzelfde licht worden ook de internationale verplichtingen die in deze context relevant zijn belicht. 
- De studie concludeert dat de vrees dat vergeldingsacties in TRIPS zich met andere internationale verplichtingen niet zou verdragen ongegrond is. Anderzijds brengt de incorporatie van de Conventies van Parijs en Bern in TRIPS, alsook de verplichtingen onder het WTO verdrag niet noodzakelijk met zich mee dat WIPO Conventies en verplichtingen niet zij uitgesloten. De systemen werken tezamen (als geheel of incrementeel).

Waar het de economische haalbaarheid van opschorting van concessies in TRIPS betreft, behandelt de studie de voornaamste uitdagingen voor de procedurele voorwaarden. De meeste WTO Leden hebben niet de economische condities die noodzakelijk zijn voor het indienen van kruislingse vergelding. Om kruislingse vergelding een rol te laten spelen in het bereiken van de doelstellingen van nakoming en toename van sociaal nut, moet het ontwikkelingsland dat TRIPS verplichtingen opschort over substantiële economische middelen beschikken om voordeel te behalen bij deze procedure.

- In essentie concludeert de studie dat het opschortende land moet beschikken over (i) een omvangrijke nationale markt; (ii) voldoende kennis; en (iii) voldoende middelen om de kosten van vergelding op te vangen.

Ten eerste, is de omvang van de nationale markt van belang omdat in het land voldoende product or dienst-gerelateerde vraag moet bestaan om de investeringen die noodzakelijk zijn om te profiteren van de opschorting van IE rechten te verantwoorden en bekostigen. Ten tweede, indien het opschortende land niet over voldoende know-how en middelen beschikt om voordeel te verkrijgen uit het opschorten van (bijvoorbeeld) een octrooi, sorteer de kruislingse vergelding geen effect. Ten derde, de implementatie van de kruislingse vergeldingsmaatregelen kan hoge investeringen met zich mee brengen om te kunnen profiteren van de opschorting van IE rechten.

Additionele uitdagingen van meer politieke aard worden behandeld in het derde deel van hoofdstuk vier. Hierin wordt aangegeven dat de grootste uitdaging voor ontwikkelingslanden om kruislingse vergelding uit te voeren waarschijnlijk gelegen is in de politieke druk die door regeringen en belanghebbenden van ontwikkelde landen wordt uitgeoefend. Van machtige IEafhankelijke bedrijven kan worden verwacht dat zijn intensief lobbyen om zo de reputatie van het ontwikkelingsland dat tracht kruislingse vergeldingsmaatregelen in te voeren te beschadigen. 
Om te zien hoe alle elementen in de praktijk werken, geeft het laatste deel van hoofdstuk vier een overzicht van de drie zaken waarin verzoeken tot kruislingse vergelding werden gedaan en gehonoreerd door de WTO, namelijk: de zaken EC-Bananas II, US-Gambling en USUpland Cotton. Dit onderdeel belicht de procedurele moeilijkheden bij het effectueren van de maatregelen, blijkens het feit dat deze geschillen niet leidden tot praktische toestemming. De analyse in dit onderdeel bevestigt ook de gemaakte aannames met betrekking tot de bovengenoemde uitdagingen en moeilijkheden, en laat zien dat binnen de groep eisende ontwikkelingslanden (Ecuador, Antigua en Brazilië) alleen Brazilië een geloofwaardige dreiging uit kon laten gaan van de voorgenomen kruislingse vergelding in TRIPS.

In het licht van de ambitie om te streven naar een betere balans in multilaterale handel concludeert de studie desalniettemin dat:

- $\quad$ De bindende nakoming van handelsregels de primaire voorwaarde is voor fair play. Kruislingse vergelding in TRIPS kan werken als een instrument voor ontwikkeling door de totstandbrenging van de verspreiding van informatie, het bevorderen van innovatie, en derhalve het vergroten van sociaal nut.

In licht van het voorgaande kunnen de conclusies van deze studie over kruislingse vergelding in TRIPS en nakomingsvraagstukken bij de WTO, met speciale de focus op de situatie van asymmetrie tussen leden gedurende de implementatie fase als volgt worden samengevat:

(i) De opkomst van de WTO en zijn geschillenbeslechtingssysteem heeft geleid tot voorspelbaarheid en juridische veiligheid in internationale handel;

(ii) Als leden van een internationale organisatie, zijn Staten (en Leden) op basis van het internationaal publiekrecht aansprakelijk voor hun handelen en niet-nakoming van verplichtingen vis à vis de WTO. Dit omvat de niet-nakoming van de verplichting uitvoering te geven aan Dispute Settlement Body (DSB) en Appellate Body (AB) uitspraken;

(iii) Aangenomen DSB uitspraken en aanbevelingen zijn bindend en moeten door de WTO Leden worden nagekomen;

(iv) De asymmetrie tussen WTO Leden, zoals beschreven in dit proefschrift, laat zich vertalen in grote discrepanties in Bruto Nationaal Product, marktaandeel, technologische middelen, innovatie en politieke macht; 
(v) Veel WTO Leden genieten niet de voordelen van het geschillenbeslechtingssysteem omdat zij niet in staat zijn de financiële middelen te vinden om hun eigen juridische capaciteit om geschillen aan te brengen te verbeteren;

(vi) Hoewel de WTO aangeeft een hoog percentage van nakoming met betrekking tot zijn geschillenbeslechtingssysteem te hebben, omvatten deze cijfers niet alleen de gevallen van volledige nakoming, maar ook gedeeltelijke nakoming of onderhandelingen tussen Leden. Echter, elk geval van niet-nakoming is zeer problematisch voor het multilateraal handelssysteem;

(vii) Het mechanisme van vergelding is een politiek instrument, dat als zodanig in staat is een geloofwaardige dreiging op te leveren voor de in gebreke blijvende partij, en is essentieel voor de werking van het systeem;

(viii) Wanneer men kruislingse vergelding overweegt, is de opschorting van IE rechten interessant, omdat dit gevoelige en belangrijke sectoren van IE-afhankelijke industrieën raakt, welke doorgaans zijn geconcentreerd in ontwikkelde landen;

(ix) Nationale uitvoering, internationale verplichtingen, economische haalbaarheid omvang van de nationale markt, voldoende kennis kosten van vergelding-, en de politieke druk zijn elementen die door het ontwikkelingsland dat kruislings wenst te vergelden in overwegingen moet nemen;

(x) De opschorting van TRIPS concessies is niet geschikt voor elk ontwikkelingsland. Alleen landen met een omvangrijke nationale markt met voldoende consumentenvraag, een ontwikkelde technische basis, en de kracht zicht te meten met de lobby's van machtige IE-afhankelijke industrieën zijn in staat voordeel te behalen uit kruislingse vergelding in TRIPS;

(xi) Niet alle ontwikkelingslanden zijn in staat om een geloofwaardige dreiging uit te laten gaan van kruislingse vergelding, waardoor collectieve vergelding een oplossing kan bieden voor het gebrek aan onderhandelingskracht van kleine economieën;

(xii) Een geloofwaardige dreiging van kruislingse vergelding in TRIPS leidt tot een zeker niveau van overredingskracht bij de WTO Leden voor nakoming van beslissingen en aanbevelingen van de DSB en $\mathrm{AB}$. 


\section{CURRICULUM VITAE}

Renata Vargas Amaral, born in 25 November 1980, studied Law at the Federal University of Santa Catarina (UFSC) - Brazil, where she obtained her bachelor degree in 2005. In 2006, Renata obtained her Master's degree in International Business Law at the Complutense Univeristy of Madrid in 2006, School of Law.

After completing her master's degree, Renata acted as a researcher at the International Relations Institute at UFSC, from 2006 to 2008. During the same period, she was a member of the International Relations Commission at Santa Catarina's Bar Association in Brazil. In 2007, Renata completed a post-graduate specialization on WTO dispute settlement at the University of Buenos Aires, Argentina.

From 2008 to 2010 she was an assistant professor at the University of the Federal District (UDF) and joined the Ministry of Development, Industry and Foreign Trade of Brazil as a lawyer for the Department of Foreign Trade. In 2010, Renata was consultant for the Department of International Affairs at the Brazilian Agency for Industrial Development. 


\section{REFERENCES}

\section{- Articles/Books/Reports}

Abbott, F. M. (2009) Cross-Retaliation in TRIPS: Options for Developing Countries. ICTSD Programme on Dispute Settlement and Legal Aspects of International Trade, Issue paper No. 8. Geneva: International Centre for Trade and Sustainable Development.

Ago, R. (1978). Scritti sulla responsabilità degli Stati I. Padova: Facoltà di Giurisprudenza dell’Università di Camerino.

Almeida, P. R. (2005) O Poder e a Glória: a questão das assimetrias no sistema international. In: Revista Espaço Acadêmico. N. 49. Published online at:

$<$ http://www.espacoacademico.com.br/049/49pra.htm>. Last accessed in: 20 Jun. 2011.

Amaral Júnior, A. (ed.) (2006). A Reforma do Sistema de Solução de Controvérsias da OMC e os Países em desenvolvimento. São Paulo: Ford Foundation.

Anzilotti, D. (1964) Corso di Diritto Internazionale. Volume Primo. Città di Castello: Società Poligrafica Editoriale.

Appleton, A. E. (2009) Suspension of Concessions in the Services Sector: Legal, Technical and Economic Problems. ICTSD Programme on Dispute Settlement and Legal Aspects of International Trade, Issue paper No. 7. Geneva: International Centre for Trade and Sustainable Development.

Azambuja, D. (1996) Teoria Geral do Estado. 35ª ed. São Paulo: Globo.

Bagwell, K.; Mavroidis, P.; Staiger, R. (2004) The case for Tradable Remedies in WTO Dispute Settlement. World Bank Policy Research Paper n. 3314.

Baptista, L. O. (2007) O Direito é História. In: Baptista, L. O.; Celli Junior, U.; Yanovich, A. (org.) 10 anos de $O M C$ : uma análise do sistema de solução de controvérsias e perspectivas.São Paulo: Aduaneiras.

Barral, W (org.) (2000) O Brasil e a OMC: os interesses brasileiros e as futuras negociações multilaterais. Florianópolis: Diploma Legal.

Barral, W.; Prazeres, T. (2002) Solução de Controvérsias. In: Barral, W. (org.). O Brasil e a OMC. $2^{\text {a }}$ ed. Curitiba: Juruá.

Barral, W. (2003) Metodologia da Pesquisa Jurídica. Florianópolis: Fundação Boiteux. 
. (2004) Solução de Controvérsias na OMC. In: Klor, A. D.; Pimentel, L. O.; Kegel, P. Solução de Controvérsia: OMC, União Européia e Mercosul. Rio de Janeiro: KonradAdenauer-Stiftung, p. 11-67.

. (2007) O Comércio Internacional. Belo Horizonte: Del Rey.

Barral, W.; Kegel, P.; Klor, A. D.; Pimentel, L. O. (2004) Solução de Controvérsias: OMC, União Européia e Mercosul. Rio de Janeiro: Konrad-Adenauar-Stiftung.

Bartels, L. (2001) Applicable Law in WTO Dispute Settlement Proceedings. In: Journal of World Trade. 35(5): 499-519. The Netherlands: Kluwer Law International.

Barton, J. H.; Goldstein, J. L.; Josling, T. E. and; Steinberg R. H. (2006) The Evolution of the Trade Regime: Politics, Law and Economics of the GATT and the WTO. United Kingdom: Princeton University Press.

Basheer, S. (2009) Turning TRIPS on its Head: An "IP Cross Retaliation" Model for Developing Countries. In: Law and Development Review, Vol. 2, No. 1. Published online at: < http://papers.ssrn.com/sol3/papers.cfm?abstract_id=1093284>. Last accessed in: 9 Jun. 2011.

Basso, M.; Beas, E. (2005) Cross-Retaliation through TRIPS in the Cotton Dispute? In: Bridges Monthly Review 9(5), p. 19-20. Published online at:

$<$ http://www.ictsid.org/monthly/bridges/BRIDGES9-5.pdf>. Last accessed in: 13 Jul. 2011.

Bilder, R. B. (2000) Beyond Compliance: Helping Nations Cooperate. In: Shelton, D. (2000) (ed.). Commitment and Compliance: The Role of Non-Binding Norms in the International Legal System. Oxford: Oxford University Press.

Bodin, J. (1977) Les six livres de la République. Aalen: Scientia.

Bown, C. P.; Pauwelyn, J. (ed.) (2010) The Law, Economics and Politics of Retaliation in WTO Dispute Settlement. Cambridge: Cambridge University Press.

Braz, M. S. A. (2006) Retaliação na OMC. Curitiba: Juruá.

Brownlie, I. (1963) International Law and the Use of Force by States. Oxford, UK: Oxford University Press.

Press.

(1983) State Responsibility (System of the Law of the Nations). Oxford: Clarendon

. (1997) Princípios de Direito Internacional Público. Tradução de Maria Manuela Farrajota, Maria João Santos, Victor Richard Stockinger e Patrícia Galvão Teles. Lisboa: Fundação Calouste Gulbenkian.

Busch, M. L.; Reinhardt, E. (2000) Bargaining in the shadow of the law: early settlement in GATT/WTO disputes. In: Fordham International Law Journal 24 (1, 2), p. 158-172.

(2002) Testing international trade law: empirical studies of GATT/WTO dispute settlement. In: Kennedy, D.; Southwick, J. (eds.) The Political Economy of International 
Trade Law: Essays in Honor to Robert E. Hudec. Cambridge: Cambridge University Press, p. 457-481.

. (2003) Developing Countries and General Agreement on Tariffs and Trade/World Trade Organization Dispute Settlement. In: Journal of World Trade 37(4), p. 719-735.

(2004) The WTO Dispute Settlement Mechanism and Developing Countries. In: Trade brief on the WTO Dispute Settlement. Sida: Department for Infrastructure and Economic Cooperation. Stockholm: Edita Sverige AB.

Busch, M.; Reinhardt, E.; Shaffer, G. (2008) Does legal capacity matter? Explaining patterns of protectionism in the shadow of WTO litigation. Published online at:

$<$ http://papers.ssrn.com/sol3/papers.cfm?abstract_id=1091435>. Last accessed in: 10 Aug. 2011.

Carvalho, N. P. (2010) The TRIPS regime of patent rights. $3^{\text {rd }}$ Ed. The Netherlands: Kluwer Law International.

Cepal - Comissão Econômica para a América Latina e o Caribe (2007). Os efeitos da globalização nas economias do Caribe pertencentes à CARICOM. Published online at $<\mathrm{http}$ //www.cepal.org/publicaciones/xml/9/10029/Por-cap11-Globalizacion.pdf $>$. Last accessed in: 27 Jun 2011.

Charlton, A.; Stiglitz, J. E. (2005) Fair Trade For All: How Trade Can Promote development. Oxford: Oxford University Press.

Charnovitz, S. (2001) Rethinking WTO Trade Sanctions. In: The American Journal of International Law. Vol. 95, N. 4, p. 792-813.

(2002) Should the Teeth be Pulled? An Analysis of WTO Sanctions. In: Kennedy; Southwick (eds.) Political Economy of International Trade Law: Essays in Honor of Robert E. Hudec. Cambridge, UK: Cambridge University Press, p. 602-635.

Charnovitz, S.; Kearns, J. E. (2002) Adjudicating in the WTO: A Review of DSU Article 21.5. In: Journal of International Economic Law. Oxford: Oxford University Press, p. 331352.

Claessens, F. (2009) Intellectual Property and Developing Countries: Balancing rights and obligations. Nijmegen: Wolf Legal Publishers.

Coleman, J.; Horlick, G. (2007) The Compliance Problems of the WTO. In: Arizona Journal of International and Comparative Law, p. 141-1147. Published online at:

$<\mathrm{http}$ //heinonline.org/HOL/Page?handle=hein.journals/ajic124\&div=17\&g_sent=1\&collectio $\mathrm{n}=$ journals $>$. Last accessed in: 10 Sep. 2011.

Correa, C. M. (2000) Intellectual Property Rights, the WTO and Developing Countries: The TRIPS Agreement and Policy Options. New York: Zed Books Ltd. . (ed.) (2010) Research Handbook on the Interpretation and Enforcement of Intellectual Property under WTO Rules. UK: Edward Elgar Publishing Limited. 
. (2009) The Push for Stronger Enforcement Rules: Implications for Developing Countries In: The Global Debate on the Enforcement of Intellectual Property Rights and Developing Countries, Programme on IPRs and Sustainable Development, Issue Paper No.22, International Centre for Trade and Sustainable Development, Geneva, Switzerland.

Correa, C. M..; Xuan, L. (eds.) (2009) Intellectual Property Enforcement from a Development Perspective. Cheltenham, UK: Edward Elgar Publishing Limited and South Centre.

Crawford, J. (2002) The International Law Commission's Articles on State Responsibility. United Kingdom: Cambridge University Press.

Cretella Neto, J. (2003) Direito Processual na Organização Mundial do Comércio - OMC: casuísta de interesse para o Brasil. Rio de Janeiro: Forense.

Chisik, R.; Onder, H. (2011) Limiting Cross-Retaliation when Punishment is Limited: How DSU Article 22:3 Complements GATT Article XXVIII. Published online at: < http://economics.ryerson.ca/workingpapers/wp025.pdf>. Last accessed in: 10 Aug. 2011.

Daillier, P; Dinh, N; Pellet, A. (2003) Public International Law. 2nd ed. Lisbon: Calouste Gulbenfian.

Dal Ri Júnior, A.; Oliveira, O. M. (ed.) (2003) Direito Internacional Econômico em expansão: desafios e dilemas. Ijuí: Unijuí.

Davey, W. J. (2001) Has the WTO Dispute Settlement System Exceeded Its Authority? In: Journal of International Economic Law, Vol. 79. Published online at: $<$ http://ssrn.com/abstract $=289249>$. Last accessed in: 16 Jan. 2008.

. (2003) The Dispute Settlement Mechanism. In: Illinois Public Law and Legal Theory Research Papers Series. Research Paper No. 03-08. Published online at: $<$ http://papers.ssrn.com/sol3/papers.cfm?abstract_id=419943>. Last accessed in: 5 May 2011.

. (2005a) Evaluating WTO Dispute Settlement: What Results Have Been Achieved

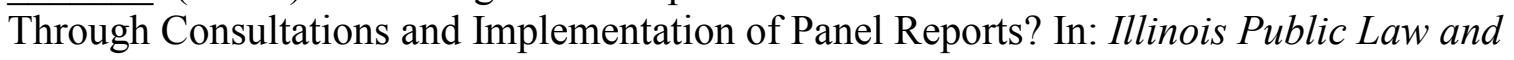
Legal Theory Research Papers Series. Research Paper No. 05-19. Published online at: http://papers.ssrn.com/sol3/papers.cfm?abstract_id=863865>. Last accessed in: 6 May 2011.

(2005b) The WTO Dispute Settlement System: the first ten years. In: Journal of International Economic Law. Vol. 8 (1), p. 17-50.

. (2005c) Implementation in WTO Dispute Settlement: An Introduction to the Problems and Possible Solutions. In: Illinois Public Law and Legal Theory Research Papers Series. Research Paper No. 05-16. Published online at: http://papers.ssrn.com/sol3/papers.cfm?abstract_id=862786>. Last accessed in: 7 May 2011.

(2009) Compliance Problems in the WTO Dispute Settlement. In: Cornell International Law Journal V. 42, p. 119-128. Published online at:

$<$ http://heinonline.org/HOL/Page?handle=hein.journals/cintl42\&div=8\&g_sent $=1 \&$ collection $=$ journals $>$. Last accessed in: 30 Jul. 2011. 
Davey, W.; Jackson, J.; Sykes Jr., A. (2002) Legal Problems of International Economic Relations: cases, materials and text on the National and International Regulations of Transnational Economic Relations. $4^{\text {th }}$ ed. St. Paul, Minn.: West Group.

David, P. A. (1992) The Evolution of Intellectual Property Institutions and the Panda's Thumb. Paper prepared for presentation at the Meetings of the International Economic Association in Moscow, 24-28 August.

Desmedt, A. (2001) Proportionality in WTO Law. In: Journal of International Economic Law. Oxford: Oxford University Press, p. 441-480.

Downs, G. W.; Jones, M. A. (2002) Reputation, Compliance, and International Law. In: Journal of Legal Studies. Chicago: The University of Chicago, p. 95-114.

Dratler Jr., J. (1991) Intellectual Property Law: commercial, creative, and industrial property. New York: ALM Properties, Inc., Law Journal Press.

Duguit, L. (1924) Soberanía y Libertad. Madrid: Librería española y extranjera.

Dunne III, M. S. (2002) Redefining Power Orientation: A reassessment of Jackson's paradigm in light of asymmetries of power, negotiation, and compliance in the GATT/WTO Dispute Settlement System. In: Law and Policy in International Business, Vol. 34, Issue 1, p. $277-$ 342.

Dupuy, P. M. (1984) Le Fait Générateur de la Responsabilité Internationale des États. Recueil des Cours de l'Académie de Droit International, v 188 (V).

Ethier, W. (2004) Intellectual Property Rights and Dispute Settlement in the World Trade Organization. In: Journal of International Economic Law 7(2), p. 449-458.

Ezeani, E. C. (2010) The WTO and its Development Obligation: Prospects for Global Trade. London: Anthem Press.

Ferrajoli, L. (2002) A soberania no mundo moderno. São Paulo: Martins Fontes.

Fink, C. (2009) Enforcing Intellectual Property Rights: an Economic Perspective. In: The Global Debate on the Enforcement of Intellectual Property Rights and Developing Countries, ICTSD IPRs and Sustainable Development Programme, Issue Paper No.22, International Centre for Trade and Sustainable Development, Geneva, Switzerland.

Flignor, P.; Orozco, D. (2006) Intangible Asset \& Intellectual Property Valuation: A Multidisciplinary Perspective. Published online at: $<$ http://www.wipo.int/export/sites/www/sme/en/documents/pdf/IP_Valuation.pdf $>$. Last accessed in: 10 Aug. 2011.

Frankel, S.; Lewis, M. K. (eds.) (2010) International Economic Law and National Autonomy. Cambridge: Cambridge University Press. 
Friedman, M. (2002) Capitalism and Freedom. 40th anniversary edition. Chicago: The University of Chicago Press.

Friedmann, W. (1964) The Changing Structure of International Law. New York: Columbia University Press.

Fukunaga, Y. (2006) Securing compliance through the WTO dispute settlement system: implementation of DSB recommendations. In: Journal of International Economic Law 9(2), p.383-426.

Ganin, D.; Schaffer, G. (2008) WTO Remedies: Extrapolating Purpose from Practice. In: Minnesota Legal Studies Paper Series. Research Paper n. 08-51. Published online at: http://papers.ssrn.com/sol3/papers.cfm?abstract_id=1321507>. Last accessed in: 10 Aug. 2011.

Garbelini Júnior, A. (2007) O sistema de solução de controvérsias da OMC nos próximos 10 anos: propostas para reformas sistêmicas e procedimentais. In: Baptista, L. O.; Celli Júnior, U.; Yanovich, A. 10 Anos de OMC. São Paulo: Aduaneiras.

Geiger, C. (ed.) (2010) Criminal Enforcement of Intellectual Property: A Blessing or a Curse? UK: Edward Elgar Publishing Limited.

Gentili, A. (2004) O Direito de Guerra. Translation of Ciro Mioranza. Ijuí: Ed. Unijuí.

Gervais, D. (2003) The TRIPS Agreement: Drafting History and Analysis. $2^{\text {nd }}$ ed. London: Sweet \& Maxwell.

Gilpin, R. (2000) The Challenge of Global Capitalism: the world economy in the 21st century. Princeton: Princeton University Press.

Graduate Institute of International and Development Studies (IHEID) (2009). Legal Memorandum on the Options for Antigua in Suspending Copyright-Related TRIPS Obligations against the US in the US-Gambling Case. Published online at: < http://graduateinstitute.ch/webdav/site/ctei/shared/CTEI/Research\%20Projects/Trade\%20Law \%20Clinic/Legal\%20memorandum\%20on\%20the\%20Options $\% 20$ for $\% 20$ Antigua $\% 20 \mathrm{in} \% 20$ Suspending\%20Copyright-

Related\%20TRIPS\%20Obligations\%20against $\% 20$ the $\% 20$ US $\% 20$ in $\% 20$ the $\% 20$ USGambling\%20Case,\%202009.pdf>. Last accessed in: 01 Sep. 2011.

Grotius, H. (2005) Do Direito da Guerra e da Paz. Translation of Ciro Mioranza. Ijuí: Ed. Unijuí.

Guzman, A. T. (2002) A Compliance-Based Theory of International Law. California Law Review. University of California, Berkeley. Published online at:

$<$ http://works.bepress.com/andrew_guzman/8>. Last accessed in: 7 Jul. 2011.

Haas, P. M. (2000) Choosing to Comply: Theorizing from International Relations and Comparative Politics. In: Shelton, D. (2000) (ed.). Commitment and Compliance: The Role of Non-Binding Norms in the International Legal System. Oxford: Oxford University Press. 
Held, D.; McGrew, A. (2003) The Great Globalization Debate. In Held and McGrew. The Global Transformations Reader: An Introduction to the Globalization Debate. 2 ed. Cambridge: Polity Press.

Henkins, L. (1979) How Nations Behave. $2^{\text {nd }}$ ed. New York: Columbia University Press. (1995) International Law: Politics and Values. Dordrecht, The Netherlands: Martinus Nijhoff Publishers.

Hilf, M. (2001) Power, Rules and Principles - Which Orientation for GATT/WTO Law? In: Journal of International Economic Law. Oxford: Oxford University Press, p. 111-130.

Hoekman, B. (2002) The WTO: functions and basic principles. In: English, P.; Hoekman, B.; Matoo, A. Development, Trade and the WTO. Washington, DC: The World Bank.

Hoekman, B. M.; Kostecki, M. M. (2002) The political Economy of the World Trade System: The WTO and Beyond. 2 ed. Oxford: Oxford University Press.

Hudec, R. (1980) GATT Dispute Settlement after the Tokyo Round: an unfurnished business. In: Cornell International Law Journal. V. 13. N. 2. Ithaca, NY: Cornell University Press.

(1987) Developing Countries in the GATT legal System. London: Trade Policy

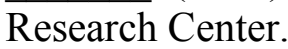

(2000) Broadening the scope of remedies in the WTO dispute settlement. In: Weiss, F. Improving WTO dispute settlement procedures: issues and lessons from the practice of other international courts and tribunals. London: Cameron May Ltd.

. (2002) The adequacy of WTO Dispute settlement Remedies. In: Hoekman, B.; Mattoo, A. and; English, P. (eds.) Development, Trade and the WTO. World Bank, Washington, DC.

International Law Commission. Yearbook of The International Law Commission 1956. Published online at: $<$ http://untreaty.un.org/ilc/publications/yearbooks/1956.htm $>$. Last accessed in: 13 Jan. 2011.

. Yearbook of the International Law Commission 1969.

Published online at: $<\mathrm{http}$ //untreaty.un.org/ilc/publications/yearbooks/1969.htm>. Last accessed in: 13 Jan. 2011.

. Yearbook of the International Law Commission 1970.

Published online at: <http://untreaty.un.org/ilc/publications/yearbooks/1970.htm>. Last accessed in: 13 Jan. 2011.

Yearbook of the International Law Commission, Part II, 2001. Published online at:

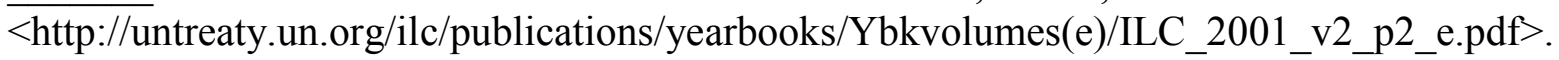
Last accessed in: 30 Aug. 2011.

International Centre for Trade and Sustainable Development (ICTSD) (2009). The Global Debate on the Enforcement of Intellectual Property Rights and Developing Countries, 
Programme on IPRs and Sustainable Development, Issue Paper No. 22, International Centre for Trade and Sustainable Development, Geneva, Switzerland.

International Monetary Fund. Globalization: Opportunities and Challenges, in World Economic Outlook, May 1997. Published online at:

$<$ http://www.imf.org/external/pubs/WEOMAY/chapter3.pdf.>. Accessed in: 20 Dec. 2010.

Jackson, J. H. (1978) The Crumbling Institutions of the Liberal Trade System. In: Journal of World Trade, V. 12, N. 2, p. 93-106.

. (1998a). The World Trade Organization: Constitution and Jurisprudence. London: Royal Institute for International Affairs.

. (1998b). Dispute Settlement in the WTO: policy and jurisprudential considerations. In: Research seminar in international economics. University of Michigan, p. 01-24.

. (2000a) The World Trading System: Law and Policy of International Economic Relations. 2 ed. Cambridge: The MIT Press.

(2000b) The Jurisprudence of GATT and the WTO: insights on treaty and economic relations. Cambridge: Cambridge University Press.

. (2000c) The Role and Effectiveness of the WTO Dispute Settlement Mechanism. In: Brookings Trade Forum, p. 179-219. Available at: $<$ http://muse.jhu.edu/journals/btf/summary/v2000/2000.1jackson.html $>$. Last accessed in: 18 Jul. 2011.

Jakobsen, K. (2005) Comércio internacional e desenvolvimento: do GATT à OMC; discurso e prática. São Paulo: Fundação Perseu Abramo.

Jellinek, G. (2000) Teoría general del Estado. Ciudad de Mexico: Fondo de Cultura Económica.

Kamiyama, S.; Martinez, C.; Sheehan, J. (2006) Valuation and Exploitation of Intellectual Property. Organisation for Economic Co-operation and Development. STI Working Paper (2006)5.

Kelsen, H. (2000) Teoria Geral do Direito e do Estado. São Paulo: Martins Fontes. (2003) Principles of International Law. Clark, New Jersey: The Lawbook Exchange Ltda.

Keohane, R. O. (1989) International Institutions and State Power: Essays in International Relations. New York: Westview Press.

Keohane, R. O.; Joseph S. Nye Jr. Globalization: What's New? What's Not? (And So What?). In Held and McGrew (2003). The Global Transformations Reader: An Introduction to the Globalization Debate. 2 ed. Cambridge: Polity Press, pp. $75-83$. 
Kessie, E. (2003) Solução de Controvérsias: Implementação e Execução. In: Conferência das Nações Unidas sobre Comércio e Desenvolvimento. Available at:

$<$ http://www.unctad.org/pt/docs/edmmisc232add23_pt.pdf $>$. Last accessed in: 26 Sep. 2007.

Koul, A. K. (2005) Guide to the WTO and GATT: Economics, Law and Politics. The Hague: Kluwer Law International.

Koh, H. H. (1997) Why do Nations Obey International Law? In: The Yale Law Journal. Vol. 106, N. 8. The Yale Law Journal Company, 1997. Published online at:

$<$ http://www.jstor.org/stable/797228>. Last accessed in: 11 Sep. 2011.

Lafer, C. (1998) A OMC e a regulamentação do comércio internacional: uma visão brasileira. Porto Alegre: Livraria de Advogado.

. (1999) Comércio, desarmamento, direitos humanos: reflexões sobre uma experiência diplomática. São Paulo: Paz e Terra.

Lakatos, C.; Walmsley, T. (2011) Dispute Settlement at the WTO: Impacts of a No Deal in the US-Brazil Cotton Dispute. Published online at:

$<$ http://www.etsg.org/ETSG2011/Papers/Lakatos.pdf>. Last accessed in: 01 Sep. 2011.

Landes, W.; Posner, R. (2003) The Economic Structure of Intellectual Property Law.

Cambridge: Harvard University Press.

Laurie, G.; MacQueen, H.; Waelde, C. (2008) Contemporary Intellectual Property: Law and Policy. Oxford: Oxford University Press.

Lawson, M. N. (2003) A Fase de Implementação no Sistema de Solução de Controvérsias da OMC: subsídios para a sua revisão. In: PIMENTEL, Luiz Otávio (ed.). Direito Internacional e da Integração. Florianópolis, Fundação Boiteux.

Leitner, K.; Lester, S. (2011) WTO Dispute Settlement 1995-2010 - A Statistical Analysis. In: Journal of International Economic Law 14(1), p. 191-201. Published online at: $<$ http://jiel.oxfordjournals.org/content/14/1/191.full.pdf+html $>$. Last accessed in: 30 Jul. 2011

Li, Y.; Mercurio, B.; Yang, G. (2005) WTO Dispute Settlement System: a detailed interpretation. The Hague: Kluwer Law International.

Mahendra, V. N. (2009) Cross-Retaliation Under the TRIPS Agreement: probing an effective strategy. Dissertation from the European Master in Law and Economics. University of Bologna.

Malacrida, R. (2008) Towards Sounder and Fairer WTO Retaliation: Suggestions for Possible Additional Procedural Rules Governing Members' Preparation on Adoption of Retaliatory Measures. In: Journal of World Trade. 42(1), p. 3-60.

Marinoni, M. (1913) La responsabilità degli Stati per gli atti dei loro rappresentanti. Roma: Athenaum.

Martins, I. G. (Coord.) (1998) O Estado do Futuro. São Paulo: Pioneira. 
Mavroidis, P. C. (2000) Remedies in the WTO Legal System: Between a Rock and a Hard Place. In: European Journal of International Law, Vol. 11, N. 4, p. 763-813.

. (2003) Instrumentos no Sistema Jurídico da OMC: Entre um Rochedo e um Lugar Difícil. In: Dal Ri Júnior, A.; Oliveira, O. M. (ed.). Direito Internacional Econômico em expansão: desafios e dilemas. Ijuí: Unijuí.

Matsushita, M.; Mavroids, P.; Schoenbaum, T. (2003) The World Trade Organization: Law, Practice and Policy. New York: Oxford University Press.

Mavroidis, P.; Palmeter, D. (2004) Dispute Settlement in the World Trade Organization: practice and procedure. $2^{\mathrm{a}}$ ed. United Kingdom: Cambridge University Press.

McRae, D. (2008) Measuring the effectiveness of the WTO Dispute Settlement System. In: Asian Journal of WTO and International Health Law and Policy. Vol. 3. N.1, p. 1-20.

Mendel, M. E. (2010) Retaliation in the WTO: the experience of Antigua and Barbuda in UsGambling. In: BOWN, Chad P.; PAUWELYN, Joost (ed.) The Law, Economics and Politics of Retaliation in WTO Dispute Settlement. Cambridge: Cambridge University Press, p. 310316.

Menell, P. (1999) Intellectual Property: General Theories. In: Encyclopedia of Law and Economics. Published online at: $<$ http://encyclo.findlaw.com/1600book.pdf $>$. Last accessed in: 18 Aug. 2011.

Mezzaroba, O.; Monteiro, C. (2003) Manual de Metodologia da Pesquisa no Direito. São Paulo: Saraiva.

Moinuddin, M.; Sengsavang, V. (2011) WTO Dispute Settlement and the Problems of Compliance: Does Cross-Retaliation under TRIPS provide a Remedy? In: Yokohama Journal of Social Sciences. Vol. 15, N. 4. Available at: <

http://kamome.lib.ynu.ac.jp/dspace/bitstream/10131/7396/1/6-Moinuddin.pdf $>$. Last accessed in: 15 Aug. 2011.

Mutlu, K.; Önis, Z. (2007) WTO at the End of its First Decade: The Political Economy df Asymmetric Interdependence. In: The Journal of International trade and Diplomacy. 1(1) Spring, p. 57-89.

North, D. (1990) Institutions, Institutional Change and Economic Performance. Cambridge: Cambridge University Press.

Nottage, H. (2010) Evaluating the criticism that WTO retaliation rules undermine the utility of WTO dispute settlement for developing countries. In: BOWN, Chad P.; PAUWELYN, Joost (ed.) The Law, Economics and Politics of Retaliation in WTO Dispute Settlement. Cambridge: Cambridge University Press, p. 319-338.

O'Connor, B. (2004) The Law of Geographical Indications. London: Cameron May Ltd. 
Oesch, M. (2003) Standards of Review in WTO Dispute Resolution. In: Journal of International Economic Law, 6(3), p. 635-659.

Oguamanam, C. (2009) Beyond Theories: The Intellectual Property Dynamics in the Global Knowledge Economy. Published online at: <

http://works.bepress.com/cgi/viewcontent.cgi?article $=1000 \&$ context=chidi_oguamanam\&seiredir $=1 \#$ search $=\% 22$ reward $\% 20$ theory\%20intellectual\%20property\%22>. Last accessed in: 20 Jul. 2011.

Oliveira, B. (2005). The Relation Between WTO Law And Public International Law: The applicable law in Dispute Settlement at the WTO. University College London. Published online at: $<$ http://papers.ssrn.com/sol3/papers.cfm?abstract_id=903052 $>$. Last accessed in: 6 May 2011.

Oppenheim, L. (1937) International Law: a treatise. $5^{\mathrm{a}}$ ed. London: Longmas, Green.

Pauwelyn, J. (2003) Conflicts of Norms in Public International Law: How WTO Law Relates to Other Rules of International Law. Cambridge: University Press.

(2010a) The calculation and design of trade retaliation in context: what is the goal of suspending WTO obligations? In: Bown, C. P.; Pauwelyn, J. (ed.) The Law, Economics and Politics of Retaliation in WTO Dispute Settlement. Cambridge: Cambridge University Press, p. 34-65.

(2010b) The Dog that Barked but Didn't Bite: 15 Years of Intellectual Property Disputes at the WTO. Published online at:

$<$ http://papers.ssrn.com/sol3/papers.cfm?abstract_id=1708026>. Last accessed in: 25 Mar. 2011.

Pereira, L. C. R. (2000). Ensaio sobre a Responsabilidade Internacional do Estado e suas Conseqüências no Direito Internacional (a saga da responsabilidade internacional do Estado). São Paulo: LTr.

Perez-Aznar, F. (2005) Countermeasures in the WTO Dispute Settlement System: An Analysis of their Characteristics and Procedure in the Light of General International Law. Studies and Working Papers, Graduate Institute of International Studies: Geneva.

Pérez Gabilondo, J. L. (2004) Manual sobre Solución de Controversias en la Organización Mundial del Comercio: principios, procedimientos, prácticas argentinas. $1^{\mathrm{a}}$ ed. Buenos Aires: Universidad Nacional Tres de Febrero.

Petersmann, E. U. (1997). The GATT/WTO Dispute Settlement System: International Law, International Organizations and Dispute Settlement. London: Kluwer Law International Ltd.

Pimentel, L. O. (ed.) (2003) Direito Internacional e da Integração. Florianópolis, Fundação Boiteux.

Plasai, V. (2007) Compliance and Remedies Against Non-Compliance Under the WTO System: Toward a More Balanced Regime for All Members. ICTSD - Dispute Settlement and 
Legal Aspects of International Trade Issue Paper No. 3. Geneva: International Centre for Trade and Sustainable Development.

Prazeres, T. L. (2009). A OMC e os Blocos Regionais. São Paulo: Aduaneiras.

Princen, S. (2004) EC Compliance with WTO Law: The Interplay of Law and Politics. In: European Journal of International Law, V. 15, N. 3, p. 555-574.

Raustiala, K.; Slaughter, A. (2002). International Law, International Relations and Compliance. UCLA School of Law Research Paper No. 347260. Published online at: $<$ http://ssrn.com/abstract=347260>. Last accessed in: 13 Set. 2011.

Reuter, P. (1989) Introduction to the Law of Treaties. London-New York: Pinter Publishers.

Ricardo, D. (1978) Princípios de Economia Política e Tributação. São Paulo: Abril.

Ridruejo, J. A. P. (1994). Curso de Derecho Internacional Publico y Organizaciones Internacionales. Madrid: Editorial Tecnos.

Rodrik, D. (1997). Has Globalization gone too far? Washington, DC: Institute for International Economics.

Rousseau, J. J. (1978). Do Contrato Social. São Paulo: Abril Cultural.

Ruse-Khan, H. G. (2008a) A Pirate of the Caribbean? The Attractions of Suspending TRIPS Obligations. In: Journal of International Economic Law 11 (2). Oxford: Oxford University Press, p. 313-364.

(2008b) Suspending IP Obligation under TRIPS: A viable alternative to enforce prevailing WTO rulings? Published online at: $<$ http://ssrn.com/abstract=1317304>. Last accessed in: 26 Aug. 2011.

. (2009) IP Enforcement Beyond Exclusive Rights. Max Planck Institute for Intellectual Property, Competition \& Tax Law Research Paper No. 09-08. Published online at: $<$ http://papers.ssrn.com/sol3/papers.cfm?abstract_id=1445292\#\#>. Last accessed in: 30 Aug. 2011.

(2010a) From TRIPS to ACTA: Towards a New 'Gold Standard' in Criminal IP Enforcement? In: Geiger, C.; Elgar, Ed. (eds) Criminal Enforcement of Intellectual Property: A Blessing or a Curse? Max Planck Institute for Intellectual Property, Competition \& Tax Law Research Paper No. 10-06. Published online at:

$<$ http://papers.ssrn.com/sol3/papers.cfm?abstract_id $=1592104 \&$ rec $=1 \&$ srcabs $=1676558>$. Last accessed in: 13 May 2011.

. (2010b) 'Gambling' with Sovereignty: complying with international obligations or

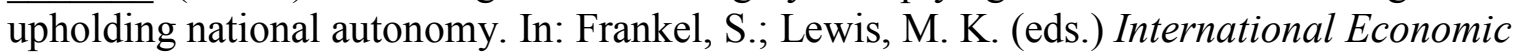
Law and National Autonomy. Cambridge: Cambridge University Press. 
Salles, L. E. (2010) Procedures for the design and implementation of trade retaliation in Brazil. In: Bown, C. P.; Pauwelyn, J. (ed.) The Law, Economics and Politics of Retaliation in WTO Dispute Settlement. Cambridge: Cambridge University Press, p. 297-309.

Sanders, A. K. (1997) Unfair Competition Law: The Protection of Intellectual and Industrial Creativity. Oxford: Oxford University Press.

. (2005) The Development Agenda for Intellectual Property Rational Humane Policy or "Modern-day Communism"? Inaugural Lecture, Institute of European Studies of Macau. Published online at: $<$ http://arno.unimaas.nl/show.cgi?fid=3156>. Last accessed in: 15 Aug. 2011.

(2007) Intellectual Property, Free Trade Agreements and Economic Development. In: Georgia State University Law Review. Vol. 23:4. Published online at: http://digitalarchive.gsu.edu/cgi/viewcontent.cgi? article $=2492 \&$ context=colpub_review\&seiredir $=1 \#$ search $=\% 22$ Intellectual $\% 20$ Property $\% 2 \mathrm{C} \% 20$ Free $\% 20$ Trade $\% 20$ Agreements $\% 20 \mathrm{Ec}$ onomic\%20Development\%20DOWNLOAD\%22>. Last accessed in: 12 Aug. 2011.

Schefer, K. N. (2010). Social Regulation in the WTO: Trade Policy and International Legal Development. Cheltenham, UK: Edward Elgar publishing Limited.

Schnell, T. (2004). The Emergence of the GATT - What do realists and neoliberal institutionalists say? Nordestedt, Germany: Grin Verlag.

Schnep, R. (2011) Brazil's WTO Case Against the U.S. Cotton Program. Congressional Research Service. Published online at: < http://www.fas.org/sgp/crs/row/RL32571.pdf $>$. Last accessed in: 02 Sep. 2011.

Shadikhodjaev, S. (2009) Retaliation in the Dispute Settlement System. The Netherlands: Kluwer Law International.

Shaffer, G. (2007). O Sistema de Solução de Disputas da OMC, seus pontos fracos e propostas de aperfeiçoamento: uma visão econômica e de mercado. In: Baptista, L. O.; Celli Júnior, U.; Yanovich, A. 10 anos de OMC. São Paulo: Aduaneiras.

. (2009) Developing Country Use of the WTO Dispute Settlement System: Why it Matters, the Barriers Posed. In: Minnesota Legal Studies Research Paper Series. Research Paper n. 08-50. Published online at $<$ http://papers.ssrn.com/sol3/papers.cfm?abstract_id=1320222\&rec=1\&srcabs $=1321507>$. Last accessed in: 11 Aug. 2011.

Shaw, M. N. (2008) International Law. Sixth Edition. Cambridge: Cambridge University Press.

Shelton, D. (2000) (ed.). Commitment and Compliance: The Role of Non-Binding Norms in the International Legal System. Oxford: Oxford University Press.

Smith, J. (2004) Inequality in international trade? Developing countries and institutional change in WTO dispute settlement. In: Review of International Political Economy. N. 11:3, p. 542-573. 
Smits, A.; Verlinden, I. (2009) Mastering the Intellectual Property Life Cycle: A global perspective on the tax-efficient management of IP rights. $2^{\text {nd }}$ ed. Belgium:

PricewaterhouseCoopers.

Sorel, J. M. (2004) Resolución de litigios en la OMC. $1^{\mathrm{a}}$ ed. Buenos Aires - Madrid: Ciudad Argentina.

Sterling, A. (2008) World Copyright Law. UK: Sweet \& Maxwell; 3rd Revised edition edition.

Stiglitz, J. (2002). Globalization and its Discontents. New York: W.W. Norton \& Company. (2006). Fair Trade for all: How can trade promote development. Brooks World Poverty Inaugural Lecture. 1 Feb. 2006. Published online at:

$<$ http://www.ljps.com.cn/oldweb/Stiglitz321/Fair\%20trade\%20for\%20all.pdf $>$. Last accessed in: 5 Jan. 2011.

Subramanian, A.; Watal, F. (2000) Can TRIPS serve as an enforcement device for developing countries in the WTO? In: Journal of International Economic Law. Oxford: Oxford University Press, p. 403-416.

Sykes, A.O. (2009) Optimal Sanctions in the WTO: The Case for Decoupling (and the Uneasy Case for the Status Quo). Stanford Law and Economics Olin Working Paper No. 379. Available at: $<$ http://ssrn.com/abstract=1444589>. Last accessed in: 18 Jul. 2011.

Thorstensen, V. (1999) OMC: As regras do comércio internacional e a Rodada do Milênio. São Paulo: Aduaneiras.

Trebilcock, M.; Howse, R. (2005) The Regulation of International Trade. $3^{\text {rd }}$ ed. London: Routledge.

Tritton, G. (2008) Intellectual Property in Europe. Third edition. London: Sweet \& Maxwell.

United Nations Economic Social Commission for Asia and the Pacific. Globalization: opportunities and challenges. Published online at:

$<$ http://www.unescap.org/pdd/publications/regcoop/ch1.pdf>. Accessed: 11 Jan. 2011.

United Nations Conference on Trade and Development - UNCTAD (2003). Dispute Settlement World Trade Organization: 3.4 Implementation and Enforcement. New York and Geneva: United Nations.

Valls, L. (1997). Histórico da Rodada do Uruguai do GATT. In: Estudos de Comércio Exterior. V. 1, n. 3.

Van den Bossche, P. (2005). The Law of the World Trade Organization. United Kingdom: Cambridge University Press.

Verdross, A. (1967) Derecho Internacional Publico. $5^{\text {a }}$ ed. Madrid: Biblioteca Jurídica Aguilar. 
Whiteman, A. L. (2010) Cross Retaliation Under the TRIPS Agreement: An Analysis of Policy Options for Brazil. Published online at:

$<$ http://www.law.unc.edu/documents/journals/articles/964.pdf $>$. Last accessed in: 20 Aug. 2011.

Yerxa, R.; Wilson, B. (eds.) (2005) Key Issues in WTO Dispute Settlement: The First Etn Years. Cambridge: Cambridge University Press.

Yu, P. K. (2011) The TRIPS Enforcement Dispute. In: Nebraska Law Review, n. 89.

Published online at:

$<$ http://papers.ssrn.com/sol3/papers.cfm?abstract_id $=1676558 \&$ rec $=1 \&$ srcabs $=1708026>$.

Last accessed in: 01 Sep. 2011.

- GATT/WTO Cases

Brazil - Aircraft (WT/DS46)

Canada - Aircraft (WT/DS70)

China - Intellectual Property Rights (WT/DS362)

EC - Hormones (WT/DS26) (WT/DS48)

EC - Bananas III (WT/DS27)

EC - Poultry (WT/DS69)

India - Patents (WT/DS50)

Japan - Alcoholic Beverages II (WT/DS8) (WT/DS10) (WT/DS11)

Korea - Alcoholic Beverages (WT/DS75)

US - Copyright (WT/DS160)

US - Byrd Amendment (WT/DS217) (WT/DS234)

US - Upland Cotton (WT/DS267)

US - Gambling (WT/DS285) 


\section{- GATT/WTO Documents}

Agreement establishing the World Trade Organization. Published online at: < http://www.wto.org/english/docs_e/legal_e/04-wto_e.htm>.

Agreement on Implementation of Article VI of the General Agreement on Tariffs and Trade 1994. Published online at: < http://www.wto.org/english/docs_e/legal_e/19-adp_01_e.htm>.

Agreement on Subsidies and Countervailing Measures. Published online at: $<$ http://www.wto.org/english/docs_e/legal_e/24-scm_01_e.htm>.

Dispute Settlement Understanding. Published online at: $<$

http://www.wto.org/english/docs_e/legal_e/28-dsu_e.htm>.

General Agreement on Tariffs and Trade - GATT 1947. Published online at:

$<$ http://www.wto.org/english/docs_e/legal_e/gatt47_01_e.htm>.

Marrakesh Agreement Establishing the World Trade Organization. Published online at: < http://www.wto.org/english/docs_e/legal_e/04-wto_e.htm>.

Trade-Related Aspects of Intellectual Property Rights - TRIPS. Published online at: < http://www.wto.org/english/docs_e/legal_e/27-TRIPS_01_e.htm>.

WTO. Recourse to Arbitration by the European Communities under Article 22.6 of the DSU. Decision by the Arbitrators (WT/DS27/ARB). 9 April 1999.

WTO. European Communities - Regime for the Importation, Sale and Distribution of Bananas - Recourse to Arbitration by the European Communities under Article 22.6 of the DSU. (WT/DS27/ARB/ECU) 24 March 2000.

WTO. United States - Section 110(5) of the US Copyright Act. Recourse to Arbitration under Article 25 of the DSU (WT/DS160/ARB25/1). 09 Nov. 2001.

WTO. Dispute Settlement Body -Special Session - Negotiations on Improvements and Clarifications of the Dispute Settlement Understanding - Communication from Ecuador (TN/DS/W/9). 08 Jul. 2002.

WTO. Dispute Settlement Body -Special Session - Negotiations on Improvements and Clarifications of the Dispute Settlement Understanding - Proposal by the African Group (TN/DS/W/15). 25 Sep. 2002.

WTO. Dispute Settlement Body -Special Session - Negotiations on Improvements and Clarifications of the Dispute Settlement Understanding - Proposal by México (TN/DS/W/23). 4 Nov. 2002.

WTO. Dispute Settlement Body - Special Session - Negotiations on the Dispute Settlement Understanding - Special and Differential Treatment for Developing Countries, [...] Sri Lanka, Tanzania and Zimbabwe (TN/DS/W/19) 09 Oct. 2002. 
WTO. Dispute Settlement Body -Special Session - Negotiations on Improvements and Clarifications of the Dispute Settlement Understanding - Proposal by Ecuador (TN/DS/W/33). 23 Jan. 2003.

WTO. Dispute Settlement Body -Special Session - Negotiations on Improvements and Clarifications of the Dispute Settlement Understanding - Communication from Kenya (TN/DS/W/42). 24 Jan. 2003.

WTO. Dispute Settlement Body - Special Session - Dispute Settlement Understanding Proposals: Legal Text - Communication from India on behalf of Cuba, Dominican Republic, [...] Honduras, Jamaica and Malaysia (TN/DS/W/47) 11 Feb. 2003.

WTO. (2004) The Future of the WTO: Addressing Institutional Changes in the Millennium. Report by the Consultative Board to the Director-General Supachai Panitchpakdi. Geneva: World Trade Organization.

WTO. Recourse to Arbitration by the United States under Article 22.6 of the DSU. Decision by the Arbitrator. (WT/DS285/ARB). 21 Dec. 2007.

WTO. Communication from Brazil. (WT/DS267/43). 12 March 2010.

WTO. Joint Communication from Brazil and the United States. (WT/DS267/45). 31 Aug. 2010.

\section{- Other relevant documents and Webpages}

Berne Convention for the Protection of Literary and Artistic Works. Published online at: $<\mathrm{http}$ //www.wipo.int/treaties/en/ip/berne/trtdocs_wo001.html $>$. Last accessed in: 19 Aug. 2011.

Câmara de Comércio Exterior. Resolução CAMEX 16, de 12 de Março de 2010. Published online at: < http://www.mdic.gov.br/arquivos/dwnl_1268663608.pdf $>$. Last accessed in: 01 Set. 2011.

Câmara dos Deputados. Brasil. Projeto de Lei 1893/2007. Published online at:

$<$ http://www.camara.gov.br/proposicoesWeb/fichadetramitacao?idProposicao=364818 $>$. Last accessed in: 10 Aug. 2011.

Intellectual Property Watch. Published online at: < http://www.ip-watch.org/>. Last accessed in: 15 Aug. 2011.

Instituto Nacional de Propriedade Industrial. Disponível em: <http://www.inpi.gov.br/>. Acesso em: 22 Ago. 2011.

Ministério do Desenvolvimento, Indústria e Comércio Exterior. Published online at: $<$ http://www.mdic.gov.br/sitio/>. Last accessed in:10 Jun. 2011. 
Oxford Dictionaries. Published online at: $<$ http://oxforddictionaries.com/ $>$. Last accessed in: 11 Jul. 2011.

Paris Convention for the Protection of Industrial Property. Published online at:

$<$ http://www.wipo.int/treaties/en/ip/paris/trtdocs_wo020.html\#P77_5133>. Last accessed in: 19 Aug. 2011.

Presidência da República. Decreto $\mathrm{N}^{\circ} 4.732 / 2003$. Published online at:

$<$ http://www.planalto.gov.br/ccivil_03/decreto/2003/D4732.htm>. Last accessed in: 30 Aug. 2011.

Lei n. 12.270, de 24 de Junho 2010. Published online at:

<http://www.planalto.gov.br/ccivil_03/_Ato2007-2010/2010/Lei/L12270.htm>. Last accessed in: 10 Sep. 2011.

Stanford Encyclopedia of Philosophy. Published online at:

$<$ http://plato.stanford.edu/entries/economics/\#5 >. Last accessed in: 22 Aug. 2011.

United Nations Charter (1945). Published online at:

$<$ http://www.un.org/en/documents/charter/>. Last accessed in: 11 Jan. 2011.

Vienna Convention on Law of Treaties (1969) Published online at:

$<$ http://untreaty.un.org/ilc/texts/instruments/english/conventions/1_1_1969.pdf >. Last accessed in: 8 Dec. 2011.

World Bank. Relatório sobre o Desenvolvimento Mundial 2006: Equidade e Desenvolvimento. Published online at:

$<$ http://siteresources.worldbank.org/INTWDR2006/Resources/477383-

1127230817535/0821364154.pdf>. Last accessed in: 03 Aug. 2011.

World Bank, 2011. Gross Domestic Product 2010. Available at:

$<$ http://siteresources.worldbank.org/DATASTATISTICS/Resources/GDP.pdf $>$. Last accessed in: 04 Aug. 2011.

World Intellectual Property Organization. Published online at:

$<$ http://www.wipo.int/portal/index.html.en>. Last accessed in: 18 Aug. 2011.

. What is Intellectual Property? Published online at:

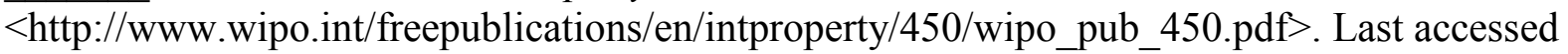
in: 30 Jul. 2011.

online at:

Convention Establishing the World Intellectual Property Organization. Published

$<$ http://www.wipo.int/export/sites/www/treaties/en/convention/pdf/trtdocs_wo029.pdf $>$. Last accessed in: 10 Aug. 2011.

Development Agenda. Published online at: $<$ http://www.wipo.int/ip-

development/en/agenda/recommendations.html>. Last accessed in: 13 Aug. 2011. 
June, 2007 .

WIPO/GEO/BEI/07/15. International Symposium on Geographical Indications, 